\title{
CONJUNTO EDILICIO MINISTERIO DE AGROINDUSTRIA DE LA NACIÓN \\ (ex Asilo Nocturno de la Capital)
}

"Desarrollo de los Instrumentos para la Conservación e Intervención del Patrímonio Arquítectónico. Hacia un Plan de Gestión"

Alumna: Arquitecta Claudia Veróníca Spiguel DNI 22.302.168

Dírector de tesis: Prof. Esp. Arq. Sergio Gutarra (FAU / CRIP / U NLP)
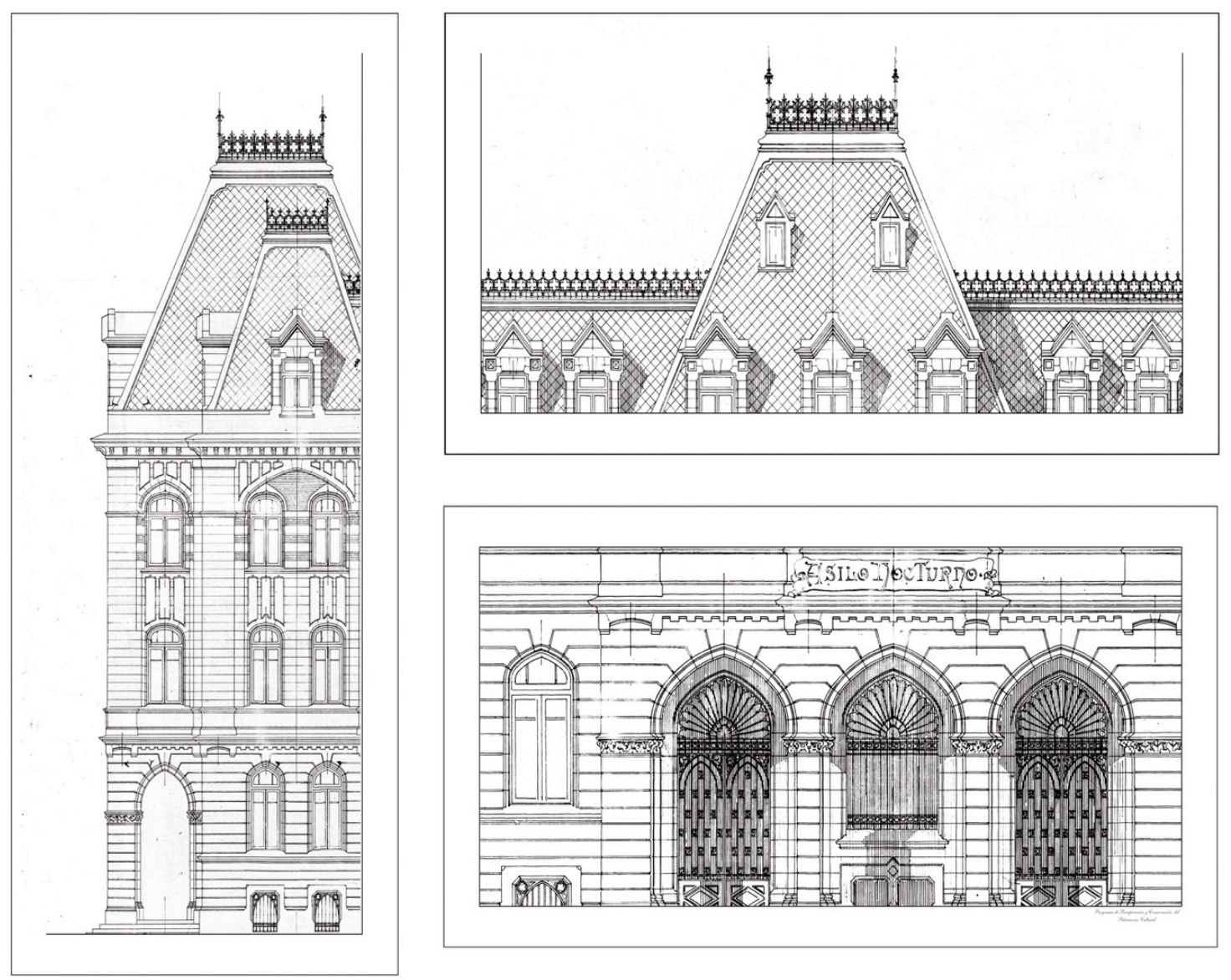

FACULTAD DE ARQUITECTURA Y URBANISMO - UNIVERSIDAD NACIONAL DE LA PLATA 


\section{ÍNDICE}

Capítulo I.- Antecedentes del origen del edificio.

Capítulo II.- Proyecto origen y sus transformaciones.

Capítulo III.- Proceso de Restauración y Readecuación edilicia.

Capítulo IV.- Identificación de patologías y desajustes.

Capítulo V.- Lineamientos para la conservación e intervención edilicia.

Capítulo VI.- Consideraciones y conclusiones finales. 


\section{CAPÍTULO I: ANTECEDENTES DEL ORIGEN DEL EDIFICIO}

Preguntas claves:

¿Qué emergentes arquitectónicos, sociales, políticos y económicos aparecieron en la época?

¿Cómo se reflejaron en la arquitectura local y que influencia tuvieron en el proyecto del conjunto edilicio?

\subsection{Antecedentes Arquitectónicos}

1.1.1. Arquitectura del siglo $X I X$

1.1.2. Repercusiones locales - Argentina

1.1.3. Conclusiones Parciales

\subsection{Antecedentes Sociales}

1.2.1. La inmigración. La legislación Inmigratoria nacional

1.2.2. Influencias sociales en la Arquitectura local

1.2.3. Respuestas políticas frente a la corriente migratoria del siglo XIX

1.2.4. Aspectos sociales en la consolidación de la ciudad moderna

1.2.5. Parámetros vinculantes con el conjunto edilicio en cuestión

1.2.6. Conclusiones Parciales

\subsection{Antecedentes Políticos y Económicos}

1.3.1. La configuración de la ciudad Capital

1.3.2. Proceso de expansión de la actividad agrícola - ganadera

1.3.3. Parámetros vinculantes con el conjunto edilicio en cuestión

1.3.4. Conclusiones Parciales

\subsection{Conclusiones}

Conjunto Edilicio Ministerio de Agroindustria de la Nación (ex Asilo Nocturno de la Capital) 


\subsection{Antecedentes Arquitectónicos}

\subsubsection{Arquitectura del Siglo XIX}

\section{Del Neoclasicismo al Eclecticismo}

Después del apogeo del estilo Barroco y sus derivaciones en los siglos XVII y XVIII, la arquitectura regresó a los estilos clásicos de una manera monumental, como reacción en contra del exceso de ornamentación en las construcciones de los siglos anteriores.

Otros factores fundamentales que influyeron en la creación de este tipo de arquitectura, fue la intensa movilización ideológica y científica generada a partir del contexto político, social y económico de la época. Específicamente en países europeos como Francia e Inglaterra, donde convergen destacadamente los movimientos de "La llustración" y "El enciclopedismo", y la fundación de las academias ${ }^{1}$.

El hallazgo de las ciudades romanas de Herculano y Pompeya (1738-1748), se convierten en testimonios fehacientes de la vida, el arte y la arquitectura de aquella lejana cultura romana con influencia griega, conduciendo a los artistas hacia el neoclasicismo buscando una visión racional originada en el orden, la proporción, la sobriedad y el equilibrio, generando un gran interés por el pasado lo que fomenta la realización de viajes de estudio hacia Roma y el sur de Italia.

Fue en Francia en donde este nuevo estilo eclosiona tras la Revolución, especialmente durante el gobierno de Napoleón, que trae la estabilidad política y económica necesaria para poder iniciar grandes proyectos constructivos basados en modelos de la antigüedad. Esto sumado a la reorganización de la enseñanza técnica, generará un nuevo perfil profesional, el ingeniero - arquitecto y una nueva cultura artística, la neoclásica, que se difundirá por el resto de Europa.

Se constituye entonces lo que se denomina el estilo imperio en el cual los arquitectos oficiales hacen realidad los deseos del emperador. París se transforma en la gran capital europea recuperando modelos arquitectónicos de carácter conmemorativo como el arco de triunfo del arquitecto Jean - Francóis Chalgrin (1806-1836) en honor a las campañas

${ }^{1}$ La primera academia "Académie d'architecture" se inaugura hacia el año 1670. 
napoleónicas, o el arco del Carrusel de los arquitectos Pierre-François-Léonard Fontaine y Charles Percier (1806-1809).

Las grandes ciudades reproducen así las formas generadas por los griegos y los romanos, suprimiendo toda referencia a las medidas del cuerpo, prefiriendo el nuevo sistema métrico adoptado por los franceses. Los arquitectos lo utilizan para diseñar edificios y monumentos de gran escala, en donde las columnas se multiplican y se apilan para dar una sensación de mayor altura, por lo que se le llamó también "orden colosal".

Sobresalen los volúmenes simétricos, aunque se evidencia la renuncia al marcado eje central. Se destaca también la racionalidad compositiva, la claridad y reducción del aspecto exterior y de las plantas, predominio de los ángulos y de las líneas rectas, cuerpos arquitectónicos estereométricos, rigurosidad y grandiosidad adecuados a las ideas o funciones que debían cumplir los edificios.

Aparecen así fachadas con frontones triangulares que sustituyen los circulares, empleando dos órdenes de la arquitectura clásica: el dórico (columnas estriadas y capitel sin molduras) y el jónico (columnas esbeltas, apoyadas sobre basa, fuste escalonado, capitel decorado con volutas, arquitrabe de tres franjas y friso libre de decoración) apartándose de la exacerbada recarga decorativa del Rococó.

Hacia finales del siglo XVIII con la revolución industrial y social, la arquitectura es dominada por los principios de configuración clásicos, generando multiplicidad de nuevos temas edilicios. Por lo que este estilo imperial no desaparece con la derrota de Napoleón, sino que se mantiene con Luis XVIII, e incluso se revitaliza a mediados del siglo XIX cuando Napoleón III crea el Segundo Imperio.

Al promediar la segunda mitad del siglo XIX, el eclecticismo se convierte en el lenguaje arquitectónico internacional, permitiendo la libre elección del estilo dentro de un repertorio historicista amplio, e incluso la combinación de elementos de diferentes vertientes en una misma obra.

\subsubsection{Repercusiones Locales - Argentina}

A finales del siglo XVIII Buenos Aires se configura todavia como una ciudad colonial en muchos de sus aspectos y costumbres. Al mismo tiempo, se reconoce un apego importante al pasado europeo tradicional que florece en la sociedad. Según el texto de 
Mario Buschiazzo, el siglo XIX en Argentina - "Los orígenes del Neoclasicismo en Buenos Aires",2 si bien no puede decirse que el arte neoclásico arranca con la creación de las academias, es indudable que la mayoría nacieron con este movimiento artístico, aún cuando América se encontraba en pleno auge del Barroco.

En el Río de la Plata, después de la Revolución, el Neoclasicismo se convirtió en el lenguaje elegido por la élite gobernante a fin de lograr una marcada diferenciación respecto del pasado colonial. Asi los profesionales de formación politécnica comenzarían a proyectar un nuevo reordenamiento en la ciudad con una impronta ligada a este nuevo estilo. Estas arquitecturas, la postcolonial y el academicismo, predominarán hacia 1810 y se extenderán hasta el año 1880.

A nivel político, este período abarca también las guerras independentistas y civiles, el ordenamiento llevado a cabo por Rosas y la reorganización del país a partir de su caída. En este contexto además del italiano Carlo Zucchi, que en su estadía en Buenos Aires (1827-1836), realiza un gran número y variedad de proyectos en su mayoría no ejecutados, se suman los primeros motivos ornamentales de la cultura clásica italiana de los siglos XVI y XVIII, dando origen al Neorrenacimiento italiano con la particularidad de un doble origen, muy semejantes entre sí:

a) De procedencia itálica, entre los que se nombran al arquitecto Pedro Fossati, Nicolás Canale y su hijo José L. Canale.

b) La británica, representada por Eduardo Taylor y Enrique Hunt, entre otros.

Los años comprendidos entre 1880 y 1920 se caracterizan por las corrientes academicistas italiana y francesa, extendiéndose en todo el territorio, en la arquitectura popular y en el nivel profesional. Allí es cuando el eclecticismo y los antiacademicismos se adoptan como lenguaje del proceso de modernización Nacional en correspondencia con el auge de la Generación del 80' y a su declinación hacia el año 1916 una vez que asume Hipólito Yrigoyen.

${ }^{2}$ Buschiazzo, Mario José (1966). El Siglo XIX en Argentina. Los orígenes del Neoclasicismo. Revista Nuestra Arquitectura, 24- 27. 
En cuanto al neogótico, estuvo limitado en su fase inicial a Buenos Aires, principalmente entre los años 1833 - 1880 y luego adquiere una amplia difusión en el resto del país.

Es también el período en el que se sitúa el crecimiento vertiginoso de tres grandes ciudades: Buenos Aires, Rosario y La Plata. Asimismo es el momento de mayor construcción de edificios públicos del país: municipalidades, universidades, escuelas, palacios de justicia, etc.

Las características estilísticas de cada uno de estos edificios, permite establecer las tendencias del panorama ecléctico local, de acuerdo a los distintos modelos culturales que hacen referencia. Estos son:

Italiano: Entre los años 1850-60 la obra de los arquitectos Pedro Fossatti, Eduardo Taylor y Carlos Pellegrini estaba marcada aún por esa misma línea neoclasicista, pero con la llegada en 1854 de los genoveses Nicolas y José Canale se inicia una tendencia hacia el neo renacimiento italiano.

Ejemplos son: el trazado urbano de Almirante Brown (Adrogué) y sus principales edificios públicos (a partir de 1873), proyectan además la iglesia de la Piedad (1850 1858).

En una segunda etapa aún más ecléctica, cuenta entre sus principales representantes a F. Tamburini con el teatro Rivera Indarte en Córdoba (1890), el Arq. C. Morra con el edificio destinado a Biblioteca Nacional (1902) y el Arq. J. Buschiazzo quien desarrolló numerosas obras públicas como el hospital Muñiz (1882-84) y la remodelación del cementerio de Chacarita (1887), además de barrios planificados, edificios religiosos, bancos y mercados.

Francés: Se difunde hacia finales de la década de 1880 y está representado por el academicismo de Beaux Arts en sus diferentes acepciones estilísticas, tanto del ámbito público como residencial privado, hoteles y edificios varios. Entre los ejemplos más representativos se encuentran los de los Arqs. R. Sergent, Maillart y Ayerza. (ver ejemplos).

Alemán: representado por los profesionales formados en instituciones académicas alemanas que ocupan cargos públicos en el país, entre los que se destacan: $C$. Altgelt miembro de Obras Públicas de la Nación y de la Dirección de Escuelas de la Provincia 
de Buenos Aires y E. Bunge con la Penitenciaría Nacional (1870) y el Hospital Alemán (1876).

Inglés: relacionado con los circuitos empresarios y financieros que aportan los capitales, la mano de obra técnica y las nuevas tecnologías para la ejecución de grandes construcciones como por ejemplo las ligadas a la infraestructura ferroviaria. Se distingue a E.L. Conder, quien construye varias estaciones del Ferrocarril Central Argentino, entre ellas la de Retiro (1910 -1914).

Español: se encuentra especialmente influenciado por el Modernismo Catalán, en especial con los proyectos a cargo de los arquitectos J. García Núñez y F. Roca.

Otro modo de concebir el eclecticismo, más allá de su lugar de origen, es por etapas o grupos.

En tal sentido según lo expuesto en "Eclecticismo en Argentina, subjetivización del lenguaje" (ensayo) ${ }^{3}$, una manera de analizar la producción ecléctica Argentina es asociando este fenómeno a tres etapas o grupos: el Academicista, el Constructivo y el Pre Racionalista.

Es asi que el Eclecticismo Academicista se define como, la sumatoria de los distintos lenguajes historicistas que mantienen la lógica propia de los elementos que lo componen.

Por su lado en el Eclecticismo Constructivo, posterior a la revolución industrial, es en donde conjugan estas nuevas corrientes. En el academicismo historicista, se genera una lucha entre el pasado y el futuro, los avances tecnológicos y la necesidad de reinterpretar la realidad, según como era conocida hasta entonces.

Por último, en el Eclecticismo Pre-Racionalista, comienzan a aparecer los primeros lineamientos del pensamiento Racionalista a través de un lenguaje propio que, ya no tiene relación directa con la lógica y morfología que caracterizaba el clasicismo.

Si bien estas categorías nos permiten encuadrar el período en cuestión, ayudándonos

3 Eclecticismo en Argentina, subjetivización del lenguaje-Ensayo para Historia III Cátedra Fernández - FADU-UBA. Extraido de internet: https://enchinche.com/eclecticismo-en-argentina/ (28/04/20) 
a comprender las distintas formas de pensamiento de la época, sus orígenes y los resultados obtenidos a partir de ellos, las obras no pueden catalogarse dentro de un grupo en particular.

En este contexto podría decirse que el conjunto edilicio motivo del presente estudio, se suscribe dentro de la etapa de Eclécticismo Academicista tomando esta distinción solo a modo referencial sin que esto implique un encasillamiento categórico.

La nueva mirada que comienza a tenerse sobre todo lo que nos rodea y se produce en este período, implica que toda valoración estética que pudiera hacerse, resulta subjetiva.

Es por ello que las construcciones adquieren autonomía y valor individual, lo que genera también un cambio de paradigmas. Los elementos del lenguaje hasta ahora existentes como símbolo, ya no representan el reflejo de la armonía universal y el concepto de belleza, ni dependen de la correcta proporción y relación entre las partes sino, de una concepción nueva y diferente en donde la ornamentación pierde sentido.

Según lo extraido del Diccionario de Arquitectura de la Argentina*:

..."El eclecticismo es el estilo que caracterizó la arquitectura del siglo XIX, derivado de la posibilidad de utilizar experiencias figurativas del pasado o de componerlas en un edificio único a través de un proceso de reelaboración de las diferencias según un determinado criterio ordenador"...

A partir de esto puede afirmarse que, el eclecticismo fue sin dudas el mecanismo a partir del cual los arquitectos encontraron herramientas para expresarse en los diversos proyectos, lo que conformaría luego parte del paisaje urbano nacional.

Esto coincide con el incipiente crecimiento poblacional producto de la inmigración, la federación de Buenos Aires y la incorporación de Argentina como modelo agroexportador dentro del mercado internacional. (Lo expuesto es complementario de lo que luego se desarrollará en los ptos 1.2. Antecedentes sociales y 1.3. Antecedentes políticos y económicos del presente capítulo).

4 J.F. Liemur, F. Aliata, Diccionario de Arquitectura en la Argentina, estilos obras biografías instituciones ciudades, Clarin Arquitectura (Julio de 2004). 


\section{Ejemplos de Obras Eclécticas de Buenos Aires}

La arquitectura local ha transitado por varias fases ligadas principalmente al tema de los usos, circunscripta a los edificios públicos de gran envergadura, las terminales de ferrocarril, los edificios eclesiásticos y las grandes residencias privadas pertenecientes a la elite de Buenos Aires.

Si bien el catálogo edilicio en la ciudad es vasto, también en relación a los estilos elegidos por los arquitectos para sus proyectos, se enumerarán parte de las obras de gran porte que tienen características afines al Ministerio de Agroindustria, tema principal del presente trabajo. Asi es que pueden citarse; el Palacio de Correo Central, el Palacio de Tribunales, el Congreso Nacional, el Teatro Colón, el Museo de Ciencias Naturales de La Plata, el Palacio Errázuriz (actual Museo Nacional de Arte Decorativo) y el Colegio Nacional de la Universidad de Buenos Aires, todos ellos dentro de la vertiente ecléctica clasicista. A continuación se detallarán algunas de ellas:

\section{$\checkmark$ El Palacio del Correo Central (Palacio de Correos y Telégrafos)}

En el año 1888 el presidente Miguel J. Celman aprobó el proyecto para la sede del Correo Central de la Argentina a cargo del arquitecto francés Norbert-Auguste Maillart egresado de Bellas Artes de París. En 1908 el mismo fue reformulado para dar lugar a la inclusión de nuevos servicios y calles peatonales aéreas que luego no se realizaron. Por desacuerdo con las autoridades, Maillart se retira y se hace cargo su colaborador el arquitecto ruso, Jacques Spolsky.

El edificio, exponente de la arquitectura del academicismo francés, fue inaugurado el 28 de septiembre de 1928, antes de que el presidente Marcelo Torcuato de Alvear terminara su mandato.

En cuanto a sus fachadas poseen un revestimiento símil piedra, realizado artesanalmente mediante la mezcla de cemento, arena y molienda de piedras generalmente importadas de Francia, ya que era un material inexistente en el país. Su acceso principal se encuentra jerarquizado por medio de un cuerpo central saliente, integrado a un sistema compositivo de elementos verticales y horizontales dispuestos 
rítmicamente que son rematados por una cubierta amansardada que incluye una cúpula trunca. (Ver Fig. No 1 y $N^{\circ} 2$ ).

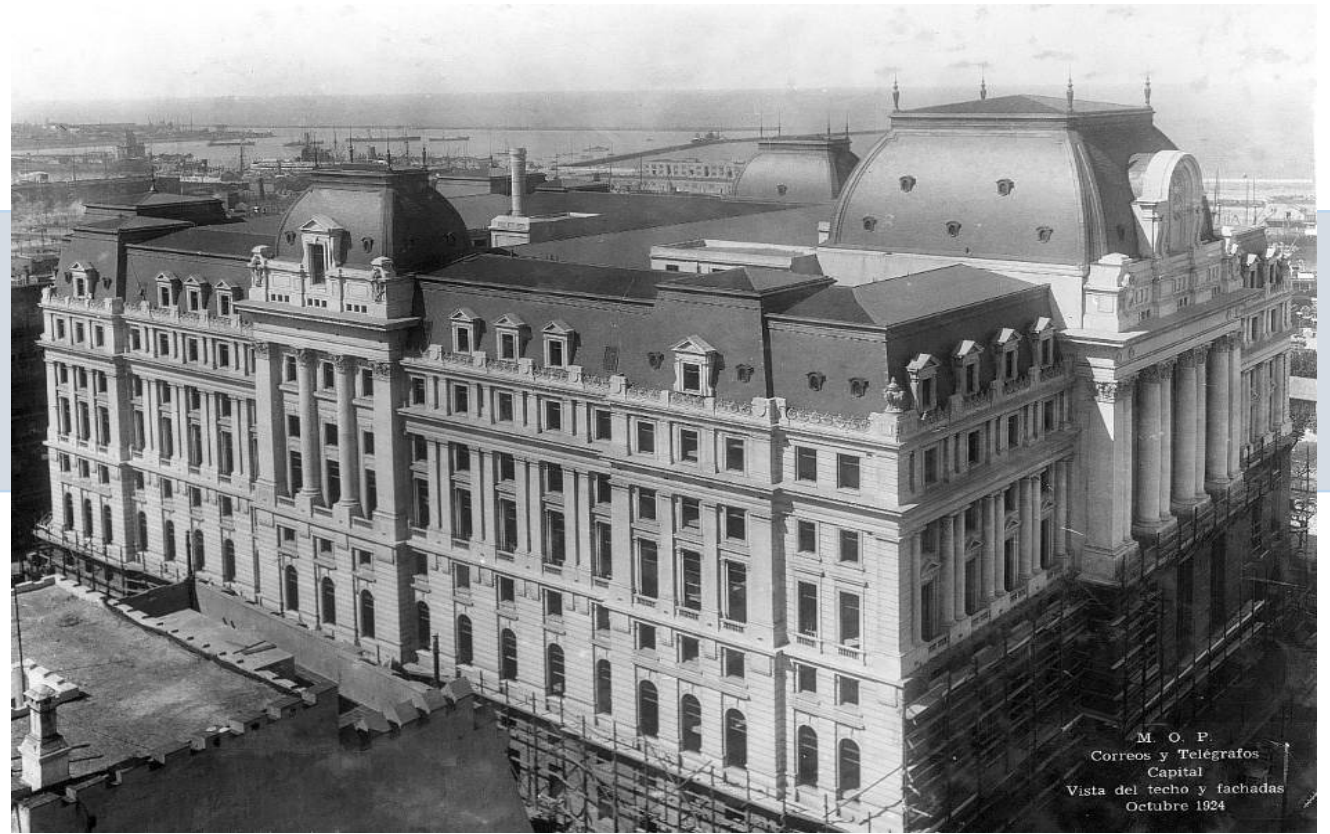

Fig. No 1.- Fotografía del Palacio del Correo (en blanco y negro) Año 1924. Digitalizada por el CeDIAP5

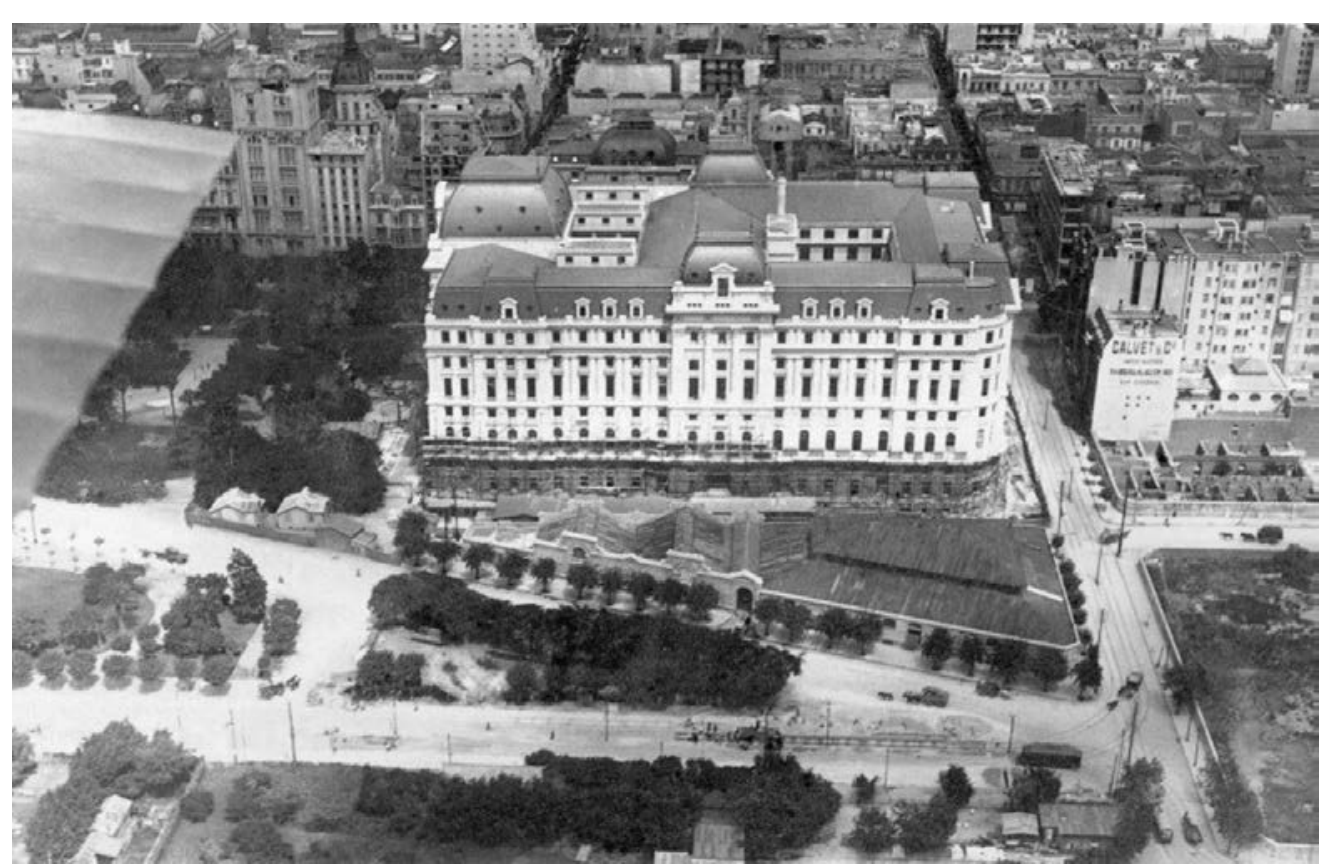

Fig $N^{\circ}$ 2.- Fotografía aérea fachada este Palacio del Correo (en blanco y negro). Autor desconocido 6

\footnotetext{
${ }^{5}$ Fuente Centro de Documentación e Investigación de la Arquitectura Pública.

${ }^{6} \mathrm{https}: / /$ www.facebook.com/buenosairesantesyahora/photos/a.389767124397553/389769204397345/?type=1\&theater Recuperado de internet de: (10/05/20)

Conjunto Edilicio Ministerio de Agroindustria de la Nación (ex Asilo Nocturno de la Capital) "Desarrollo de los instrumentos para la Conservación e Intervención del Patrimonio Arquitectónico. Hacia un Plan de Gestión".
} 
Distribuído en nueve niveles (subsuelo, planta baja y siete pisos superiores) originalmente estaba dividido en una parte "noble", que albergaba las oficinas de la administración, despachos y salones. El resto del edificio denominado área 'industrial", estaba conformado por grandes espacios interiores en donde se realizaba el trabajo de procesamiento con la posterior clasificación del material postal o telegráfico y los depósitos que se agrupaban sobre las fachadas y alrededor de un gran patio central de aire y luz.

El edificio sufrió profundos cambios en relación a su concepción original, motivados por consideraciones de programa que dan cuenta de la necesidad de adecuación de un proyecto que enfrentó múltiples dificultades y complejidades, incluida la demora durante décadas en su construcción y la dramática escasez de materiales producto de la 1era Guerra Mundial, que obligó a suspender algunas de las modificaciones propuestas. Estas readaptaciones estuvieron a cargo de la Dirección Nacional de Arquitectura del Ministerio de Obras Públicas de la Nación.

Entre las modificaciones que el edificio atravesó, se destaca el reemplazo de la estructura de muros macizos de albañilería por un esqueleto metálico y, a su vez, el reemplazo de los entrepisos de bovedillas por losas de hormigón armado. Esta nueva estructura, parece una decisión acorde a los progresos que se producen en el desarrollo de técnicas y tecnologías constructivas en acero de la época lo que permite generar espacio destinado a los muros de carga y otorga, en cambio, una notable regularidad y libertad de ordenamiento al espacio interior.

Por tratarse de terrenos ganados al río, se realizó un sistema de pilotes de hormigón armado a unos diez (10) metros de profundidad unidos por una losa superior, a modo de viga a fin de permitir distribuir las cargas del edificio al terreno.

Otro aspecto interesante fue la elección de un equipamiento de vanguardia para la época.

Hacia el año 1983 la Dirección de Paseos de la Comuna inaugura una plaza frente a la entrada principal del edificio resaltando su riqueza arquitectónica y enriqueciendo su relación con el entorno próximo. 
Fue declarado por ley Monumento Histórico Nacional hacia el año 1997, además de poseer una protección integral ${ }^{7}$ continuando funcionando como Palacio de Correos hasta el año 2003.

Dos años más tarde se llama a concurso para la búsqueda de la mejor alternativa de uso y ocupación del edificio. Tanto los trabajos premiados como en general todos los presentados, orientaban su transformación hacia un uso cultural. Es asi que, la propuesta para el Centro Cultural del Bicentenario fue el resultado de un segundo concurso del año 2007, cuyo primer premio se otorgó a los estudios de arquitectura Bares y Asociados (B4FS), de La Plata y Becker Ferrari, de Buenos Aires.

Las bases del concurso proponían por un lado una serie de operaciones tendientes a la restauración, reciclaje y puesta en valor del edificio interviniendo sobre el área Histórica o Ceremonial; y por el otro la refuncionalización del área industrial que sería objeto de múltiples cambios en su interior. Todo esto de acuerdo a las exigencias del programa de necesidades, a las consignas tecnológicas pre establecidas y a las condiciones de seguridad, habitabilidad y confort surgidas a partir de las premisas emergentes de su nuevo uso. El corazón del proyecto incluía además, la construcción de una gran sala sinfónica, auditorios de diferentes tamaños y lugares para exposiciones.

También se solicitaban ideas respecto al entorno urbano como articulación entre el edificio y la ciudad. Haciendo hincapié en la necesidad de obtener como resultado la suficiente flexibilidad espacial como para permitir modificaciones futuras.

En este contexto la nueva intervención debía afectar lo mínimo posible la composición original de su envolvente, incuyendo paños de mampostería y carpinterías, entre otros.

Luego de los años que duró el proceso de su puesta en valor, fue reinaugurado el 21 de Mayo del año $2015 .^{8}$

\footnotetext{
7 Fue declarado Monumento Histórico Nacional por Dec. N²62 del 20/03/97. Forma parte de un área de protección histórica s/ Art.5.4.13 del Código de Planeamiento Urbano de la ciudad de Bs.As. (con grado de protección estructural). 


\section{$\checkmark$ El Palacio de Justicia de la Nación (Palacio de Tribunales)}

El Palacio de Justicia sede de la Corte Suprema y otros tribunales, fue proyectado por el arquitecto francés Norbert Maillart en 1889, durante la presidencia de Miguel J.Celman.

Debido a una profunda depresión que derivó en una crisis económica y financiera durante el gobierno de Carlos Pelegrini la obra se paralizó por casi veinte (20) años. En 1903 se produjo el traspaso del parque de artillería del Ministerio de Guerra al Ministerio de justicia e instrucción Pública, para la construcción del Palacia de Justicia. Recién durante la segunda presidencia de Julio A. Roca se retomó, iniciándose en 1905.

En 1910 el presidente José Figueroa inauguró una parte del Palacio de Justicia Alcorta, en el marco del Centenario de la Revolución de Mayo. Con el estallido de la 1era Guerra Mundial en 1914, y por problemas administrativos y presupuestarios, se suspenden nuevamente los trabajos para retomarse en la década de 1920.

Hacia 1925, se modificó el proyecto original debido al crecimiento del Poder Judicial, construyendo un piso más, completándose en 1942 cuando se finalizó la Sala de Audiencias.

Este edificio academicista constituye lo que se denomina un edificio "exento", emplazándose sobre las calles Lavalle, Tucumán, Talcahuano y Uruguay, en posición estratégica respecto de los otros centros de poder político de la época y siendo precedido por un pulmón verde, la plaza Lavalle.

Los materiales utilizados para la construcción del Palacio como: bronces, mármoles, vitrales, pizarras enmarcan al edificio dentro de un criterio estético con tendencia hacia la majestuosidad que fue en definitiva lo que caracterizó a las edificaciones, tanto públicas como privadas del momento.

Su fachada ecléctica de composición axial, es acompañada por una escalinata en posición central que remarca el acceso elevado respecto al nivel peatonal, acentuando la escala monumental del edificio. (Ver Fig. №3). 


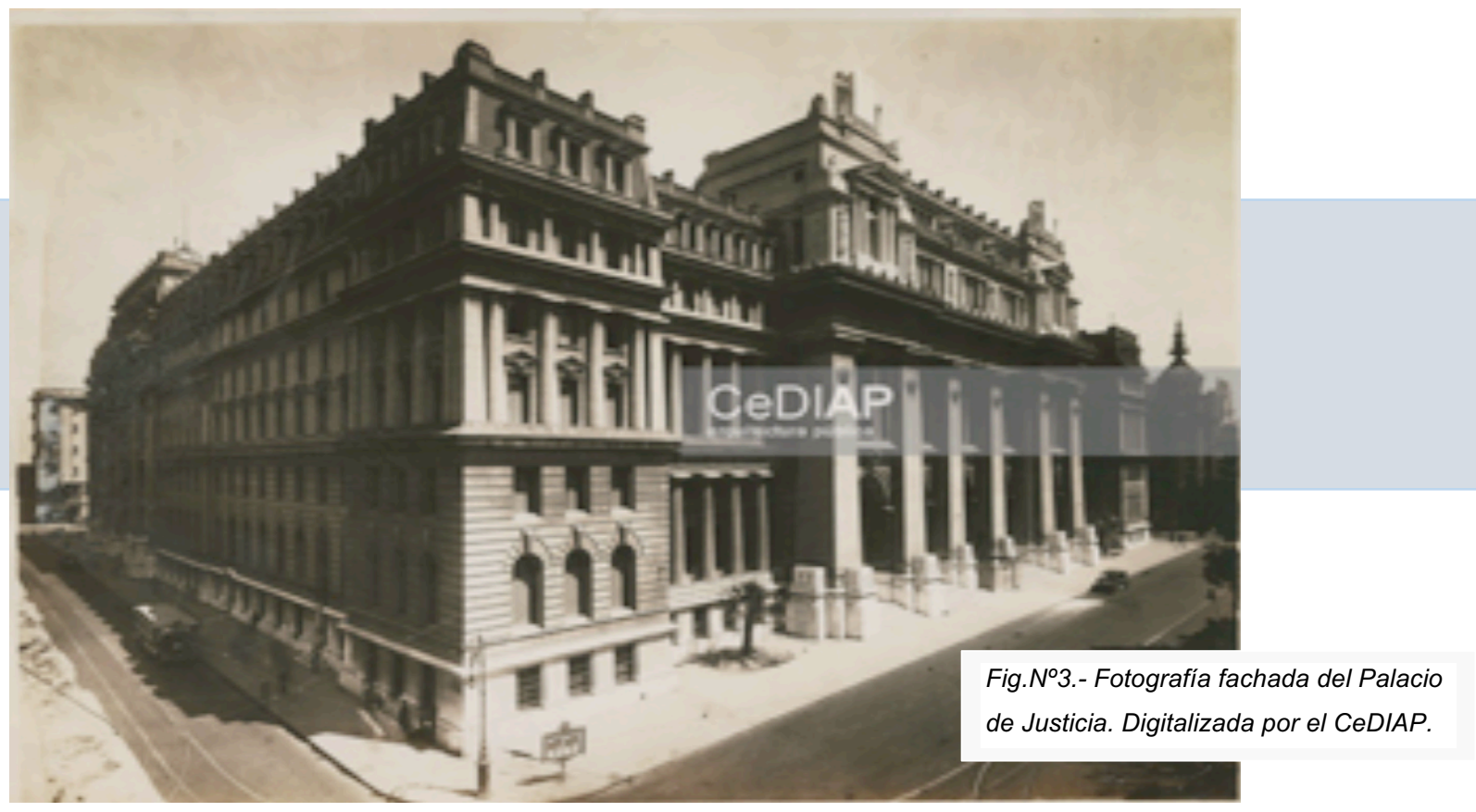

Lo mismo se repite en el interior con una sucesión simétrica de espacios que se articulan con patios internos de distinta jerarquía. Es importante destacar que estos patios, son elementos proyectuales muy utilizados en la mayoría de los edificios públicos de la Capital como así también en los incluidos en el presente capítulo. (Ver Fig. № 4).

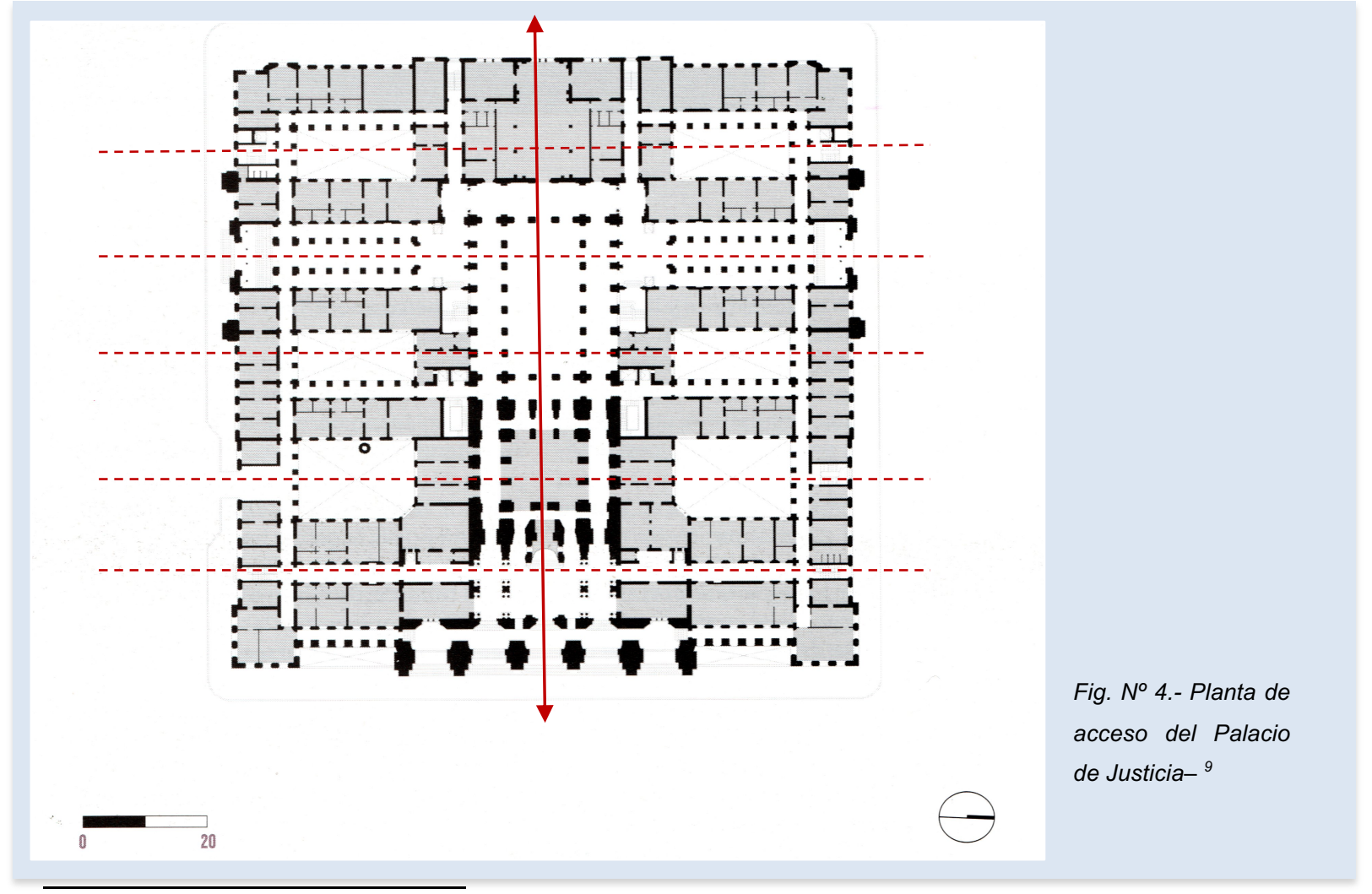

${ }^{9}$ Susini Burmester, C. "Palacio de Justicia. Templo ecléctico para los tribunales"; "Cabildos, casas de gobierno y edificios públicos"' Incollá, M. de las nieves, ed. literaria a cargo de Berto González Montaner.1ª ed. Bs.As. Arte Grafico Editorial Argentino, año 2012 (pág. 106 a 115).

Conjunto Edilicio Ministerio de Agroindustria de la Nación (ex Asilo Nocturno de la Capital) "Desarrollo de los instrumentos para la Conservación e Intervención del Patrimonio Arquitectónico. Hacia un Plan de Gestión”. 
En el año 1995 y luego de décadas sin el mantenimiento adecuado, comienza a comprobarse un alto deterioro con desprendimientos en las fachadas del edificio por lo que se iniciaron tareas de consolidación. Hacia 1997 se propone realizar una prueba piloto para estudiar la materialidad, las lesiones y patologías, el comportamiento de los materiales de reposición en relación con los existentes y los sistemas de limpieza. Entre los años 2002 - 2007 se inicia un complejo proceso de intervención con el armado de andamios por sectores y etapas sucesivas, en las fachadas principales (calles Talcahuano y Uruguay) como así también en el interior del edificio.

En 2010, comenzaron las obras faltantes, correspondientes a los frentes laterales de las calles Viamonte y Lavalle, últimas necesarias para que el exterior del edificio Monumento Histórico Nacional, ${ }^{10}$ recuperara su aspecto original. Las etapas de trabajo contemplaron la limpieza del sustrato, el tratamiento de los hierros expuestos, de mampostería, premoldeados y friso, trabajos de herrería, mármoles, mansarda, equipos de aire acondicionado, sistema ahuyenta aves, cubiertas, desagues y canaletas, rejas de ventanas del subsuelo y carpinterías en general.

\section{$\checkmark$ El Congreso Nacional}

Tal como ocurrió con otros edificios públicos hacia fines del siglo XIX, se hace imprescindible asignar al Poder Legislativo una sede definitiva. Es asi que en 1894 con la inauguración de la Avenida de Mayo, el poder ejecutivo es autorizado a llevar a cabo la construcción del Palacio del Congreso.

En 1889 el presidente Juárez Celman envió al Congreso de la Nación un proyecto de ley que proponía como locación para el nuevo Palacio, la manzana comprendida por la calles Entre Ríos, Combate de los Pozos, Victoria (hoy Yrigoyen) y Rivadavia. La elección del lugar resultaba estratégica por cuanto representaba el remate del trazado de la Avenida de Mayo, en cuyos extremos se situarían la Casa de Gobierno y el Cabildo histórico, por un lado, y el Congreso Nacional, por el otro.

A tal efecto se llamó a un concurso internacional, organizado por la Sociedad Central de Arquitectos y la obra fue adjudicada al arquitecto italiano Victor Meano. La idea rectora reconocía como fundamento tres ejes centrales: el academicismo, el eclecticismo y el

10 Declarado Monumento Histórico Nacional por decreto N 349/99. 
clasicismo, pero además poseía características únicas que no solo lo diferenciaban del resto de las ideas presentadas sino que lo llevaron a ser la propuesta elegida para ganar el concurso.

Tal lo expresado en el texto del libro "Palacio del Congreso Nacional, Historia de su arquitectura"11 (pág.56) cuando refiere a los fundamentos por los cuales los miembros del jurado premiaron a Meano:

\begin{abstract}
..."El proyecto a adoptarse debía ser aquel que permitiese resultar el primer monumento arquitectónico de la capital Argentina y su principal ornamento. Débese tener presente, ante todo, la grandiosidad del edificio, su belleza arquitectónica, la majestad del monumento destinado a impresionar la imaginación del forastero y del argentino y llamado a imprimir en su ánimo el concepto, la altísima idea de la potencialidad, de la fortuna, de los altos destinos de la patria"...
\end{abstract}

La idea de edificio monumental tal lo expresado por el jurado para la selección de este proyecto representa, sin dudas, el pensamiento regente de la época y es el concepto que acompañó la concepción de todas y cada una de las instituciones de la República.

Con la construcción del Palacio del Congreso, surgió la idea de incorporar una plaza que reforzara su monumentalidad y consolidara la presencia del eje institucional del poder ejecutivo con el legislativo, continuando con lo proyectado por Meano según lo que había formulado en la memoria del edificio. (Ver Fig. №5 y 6).

Así, por iniciativa del senador Miguel Cané, en 1905 se sancionó la Ley que establecía la creación de la Plaza del Congreso en terrenos expropiados. En 1906 los legisladores decidieron que el inminente período legislativo debía iniciarse en el nuevo edificio, que aún no estaba terminado. Así fue que el 12 de mayo de 1906, durante la presidencia de José Figueroa Alcorta, se inauguró el Palacio Legislativo en un recinto de sesiones todavía sin terminar.

\footnotetext{
11 Aliata, F. R., Carasatorre C.,Della Védova F., Garcia G.F.R.,Iturria V., Ponce N.Sessa E.T., Tuler S. Palacio del Congreso Nacional, Historia de su arquitectura, 1ed. CABA, Editorial de la Imprenta del Congreso de la Nación, (2015) Recuperado de internet https://issuu.com/frentemarchita/docs/libro-palaciolegislativo-26x30-comp (01/05/20). Arquitectónico. Hacia un Plan de Gestión”.
} 
FACULTAD DE ARQUITECTURA Y URBANISMO - UNIVERSIDAD NACIONAL DE LA PLATA MAESTRÍA EN CONSERVACIÓN, RESTAURACIÓN E INTERVENCIÓN DEL PATRIMONIO ARQUITECTÓNICO Y URBANO (CRIP - FAU / UNLP)

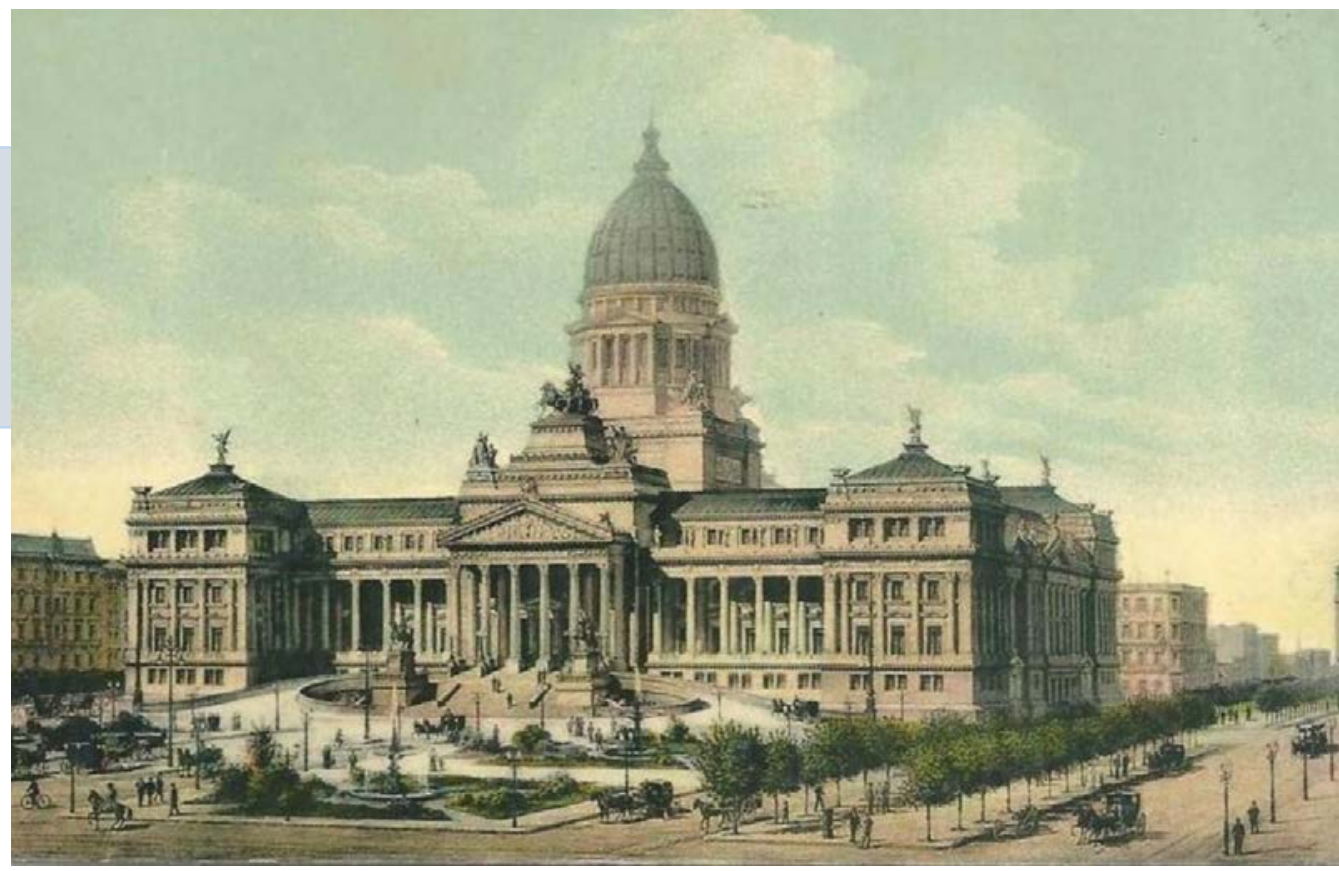

Fig. N`5.- Imágen en perspectiva del Congreso Nacional, autor Vittorio Meano (1896) ${ }^{12}$.

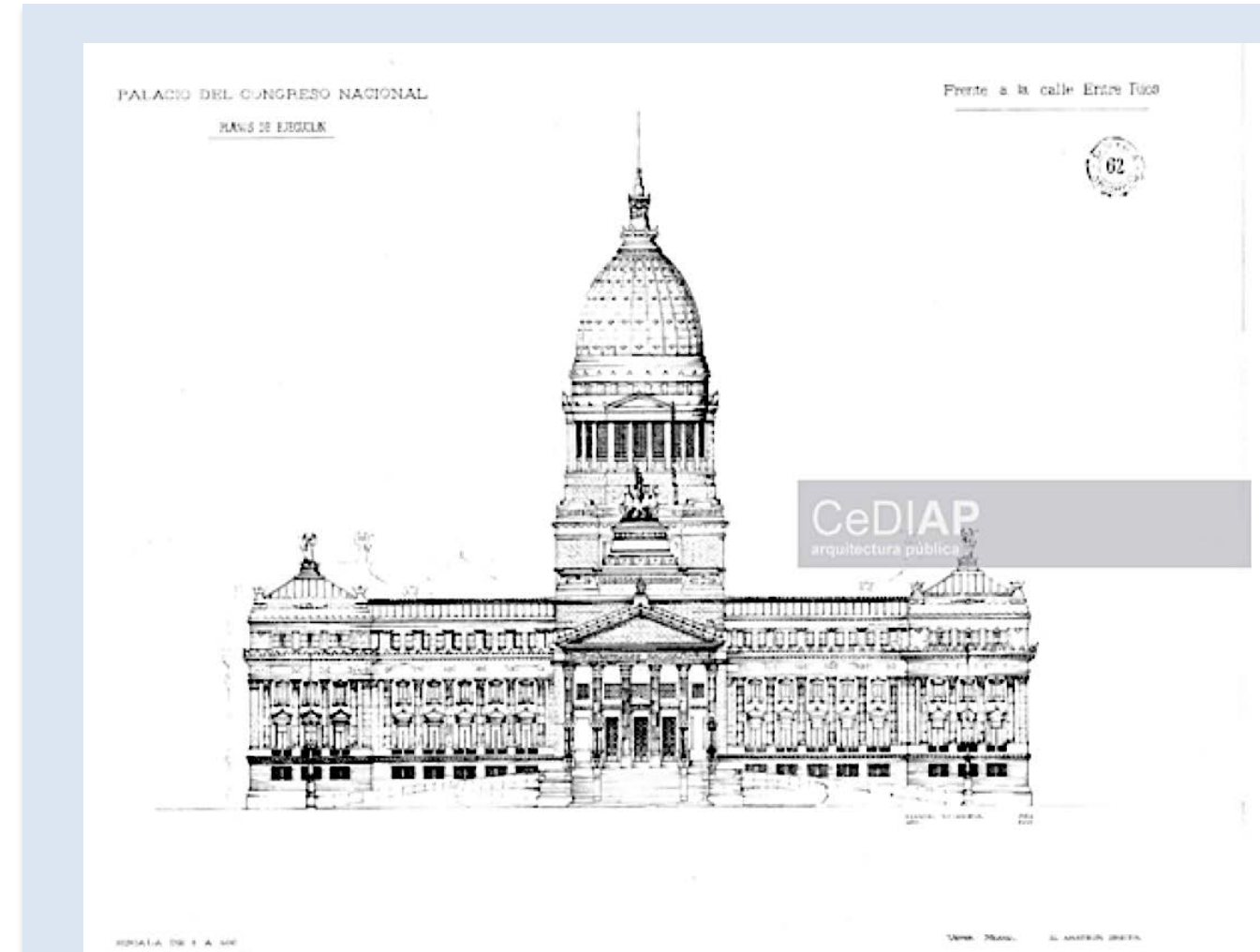

Fig. Nº 6. Imágen de la fachada principal del Congreso Nacional. Digitalizada por el CeDIAP.

\footnotetext{
${ }^{12}$ Recuperado de internet https://www.danielschavelson.com.ar/?cat=70 (10/05/2020) - El Proyecto de Vittorio Meano para el Teatro Colón de Buenos Aires.
} 
El edificio fue atravesado por distintas ampliaciones y adiciones motivadas por los cambios en el confort, como por ejemplo el cierre de las galerías de los patios y la necesidad de la modernización de sus servicios que habían sufrido cambios rotundos luego que Meano lo proyectara y hasta que quedó concluido en 1946.

En cuanto a su morfología, la obra está constituída por una gran masa muraria de perímetro libre, distribución tripartita en el sentido horizontal, un basamento de granito, el desarrollo definido por el orden que toma los pisos principales y la culminación con la cúpula que no solo acentúa la simetría del conjunto sino que además coloca al edificio en la dimensión de una escala urbana metropolitana. La fachada principal contiene pórticos en su frente que se repiten en las alas laterales. (Ver Fig. $N^{\circ} 7$ )

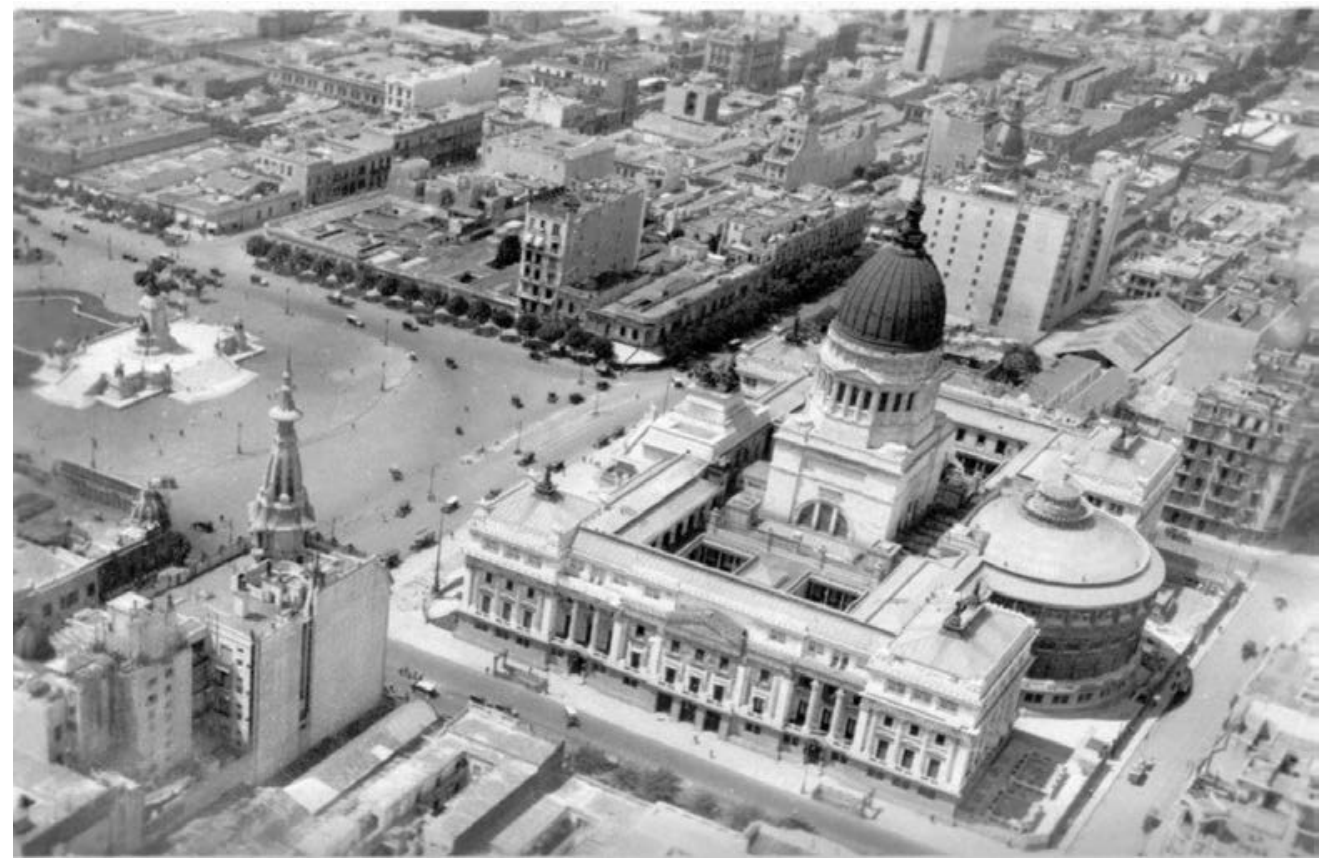

Fig. Nº 7.- Imágen aérea del Congreso Nacional, fotografía blanco y negro (año 1920)-autor desconocido ${ }^{13}$

Funcionalmente se organiza en base a dos ejes de composición perpendiculares (esteoeste) correspondientes al acceso principal, vestíbulos, salones y finalmente la cámara de diputados, mientras que los ejes norte - sur albergan los accesos secundarios, salones varios y recinto de senadores. Es declarado Monumento Histórico y Artístico Nacional según el decreto N 2676-93. (Ver Fig. № 8).

${ }^{13}$ https://www.facebook.com/buenosairesantesyahora/photos/a.389767124397553/389768477730751/?type=1\&theater. (10/05/20) Recuperado de internet. 


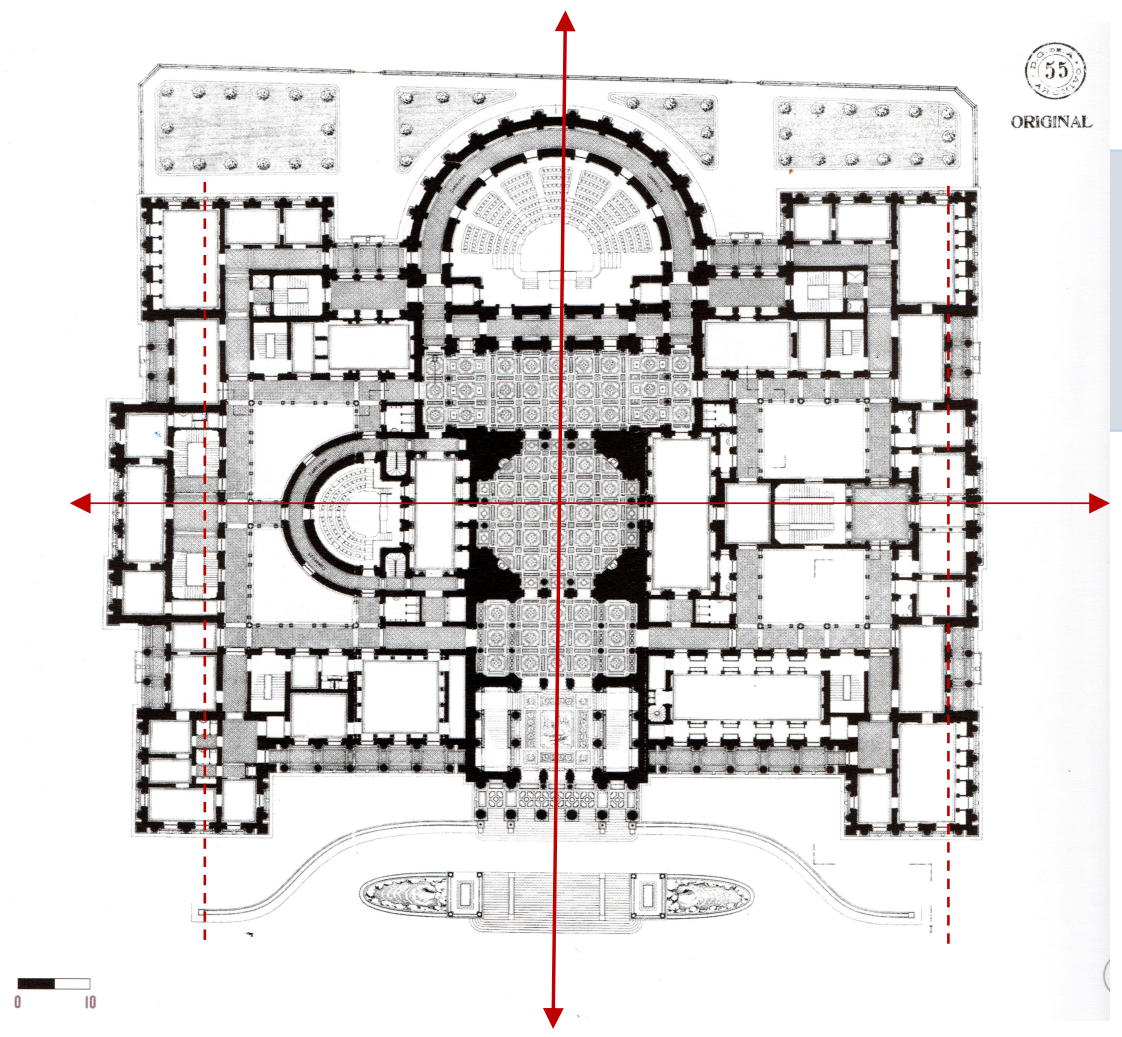

Fig. No 8.- Planta del 1er piso del Congreso Nacional. 14

En el año 2012 y a través del Plan Rector de Intervenciones Edilicias (PRIE), se comienza a dar un enfoque multidiciplinario de preservación del edificio abarcando la restauración, la puesta en valor integral, la adecuación tecnológica y funcional del bien.

A partir de la puesta en marcha de este plan, se inician tareas que incluyeron el relevamiento, el registro, el análisis, la determinación del estado de conservación, las patólogias, desajustes o daños encontrados y los mecanismos de rescate tanto del patrimonio inmueble como mueble ya que se concibe al edificio como un bien integro en donde cada una de sus partes conforman el todo. De esta forma se elaboraron los estudios correspondientes para definir las intervenciones.

Desde finales del 2019, el edificio se encuentra sometido a un proceso de puesta en valor de su fachada sobre Av. Entre Ríos, lindante con la plaza que lleva su nombre.

14 Bozzano, J.N. "Palacio del Congreso de la Nación" "Cabildos, casas de gobierno y edificios públicos", Arias Incolla, M.de las Nieve, ed.literaria a cargo de Berto González Montaner. $1^{a}$ ed. BsAs Arte Grafico Editorial Argentino, 2012 (pág. 82-93). 


\section{$\checkmark$ EL TEATRO COLÓN}

El Teatro Colón inició sus actividades en un edificio ubicado frente a la Plaza de Mayo, donde hoy se encuentra el Banco Nación y funcionó allí entre los años 1857- 1888. La nueva construcción emplazada entre las calles Cerrito, Viamonte, Tucumán y Libertad se inició en 1890, con la intención de inaugurarlo antes del 12 de octubre de 1892, en coincidencia con el 4to Centenario del descubrimiento de América.

El proyecto para el teatro fue encargado al arquitecto Francesco Tamburini, quien cumplía funciones como director general de arquitectura de Argentina. Tras su muerte, éste fue continuado y modificado por su socio, el arquitecto Víctor Meano. (Ver Fig. № 9).

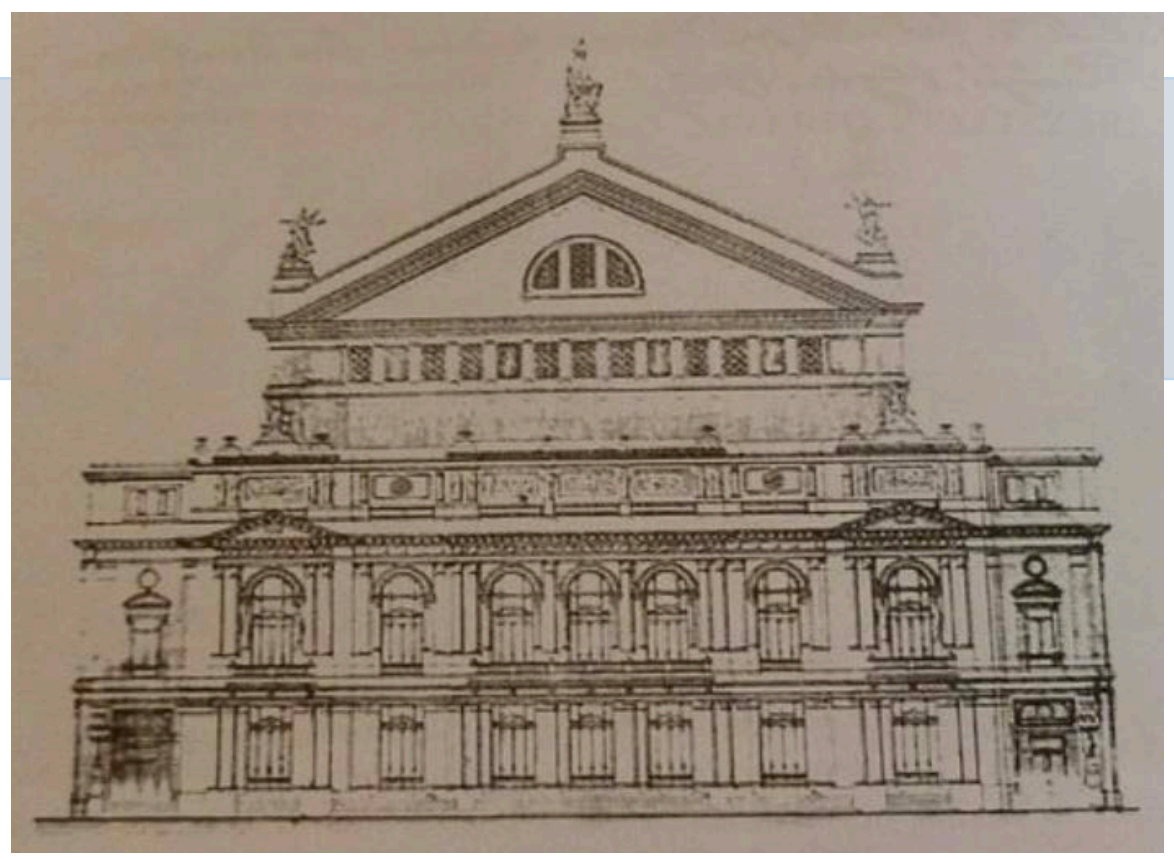

Fig. No 9.- Diseño de la fachada del Teatro Colón, dibujo del Arqto Victor Meano, año $1892 .{ }^{15}$

Las obras avanzaron hasta 1894 , pero se estancaron por cuestiones financieras. En 1904, al morir Meano, el Gobierno solicitó al belga Jules Dormal que la termine. Este introdujo algunas modificaciones estructurales y dejó definitivamente impreso su sello en el estilo francés de la decoración de los balcones superiores, las dimensiones de espacios como los vestíbulos y halls, siendo inaugurado el 25 de Mayo de 1908. El

\footnotetext{
${ }^{15}$ Pellizzari de Hermitte, A. T. M (2013). Teatro Colón. Historia de la construcción, Buenos Aires, Ed. De los Cuatro Vientos( pág. 60). 


\section{MAESTRÍA EN CONSERVACIÓN, RESTAURACIÓN E INTERVENCIÓN DEL PATRIMONIO ARQUITECTÓNICO \\ Y URBANO (CRIP - FAU / UNLP)}

edificio sin dudas se enriqueció arquitectónicamente en función de los largos años de construcción y el complejo proceso de diseño, donde se mixturaron los estilos de estos tres arquitectos, siendo entre ellos de diverso origen y formación académica.

El resultado final se traduce como una robusta edificación, que sigue tanto en su fachada como en su distribución interior, las matrices académicas de origen italiano y francés. Su composición simétrica está enfatizada en su parte central por una marquesina y una escalinata que jerarquizan el acceso al teatro. La transición entre el exterior y el interior se produce mediante un gran foyer, que constituye uno de los elementos ampliamente utilizados en los edificios emblemáticos de la época. La sala principal del teatro tiene forma de herradura y sigue la estructura clásica de los teatros italianos. Por otro lado los palcos abiertos, los vestíbulos, los foyers de amplio desarrollo conforman espacios de distintas jerarquías espaciales y decorativas típicos de la tradición francesa. El empleo de una estructura combinada de hierro y hormigón armado, transforma al Teatro en el primer gran edificio de la ciudad, donde se experimenta este tipo de sistema estructural mixto.(Ver Fig. № 10 y No 11).

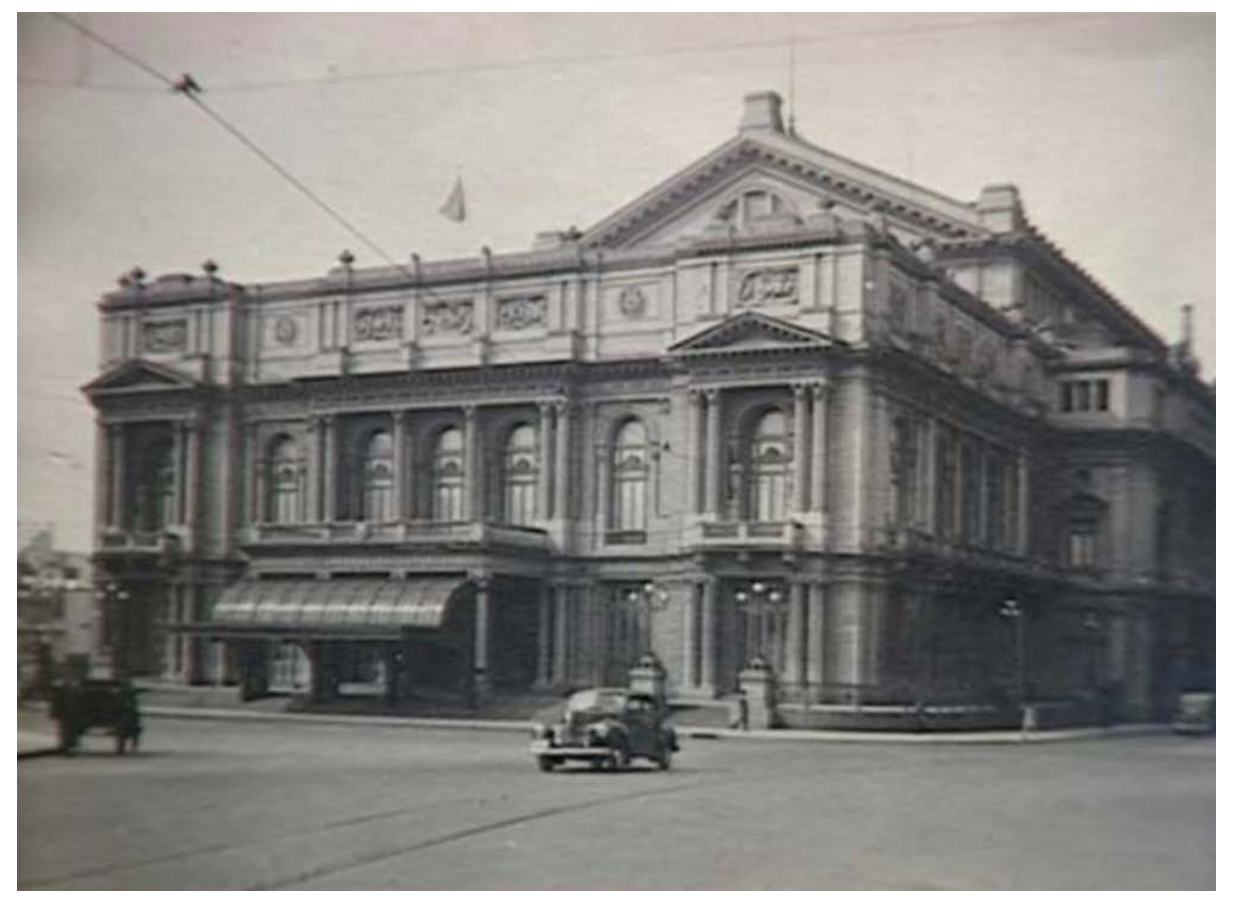

Fig. N N 10.- Fachada oeste del Teatro Colón ${ }^{16}$

\footnotetext{
${ }^{16}$ https://es. wikiarquitectura.com/edificio/teatro-colon/ \#0001-teatro-colon. Recuperado de internet (10/05/20)
} 
Fig. No11.- Plano nivel de acceso del Teatro Colón, dibujo del Arqto Victor Meano, año $1898^{1}$.

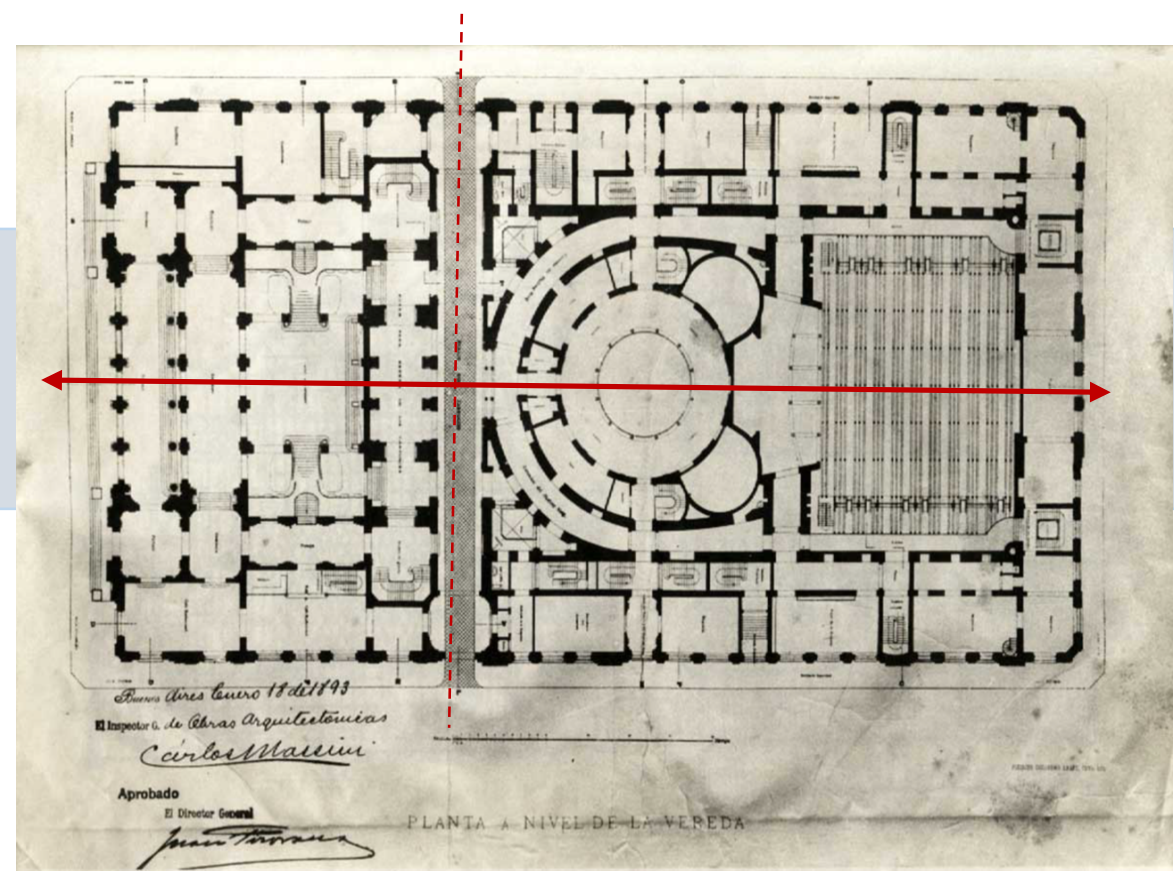

Respecto a su conservación, en el año 1989 se declara al Teatro Colón como "Monumento Histórico Nacional". A partir del año 2006 la ciudad encaró un ambicioso proceso de recuperación, por lo que el edificio fue sometido a un profundo estudio para definir las intervenciones necesarias tanto para la conservación del Monumento Histórico como para su adecuación tecnológica, jerarquización del entorno urbano del teatro y recuperación de la plaza del Vaticano, entre varios otros.

Así es que se pudieron establecer una serie de objetivos: más salas de ensayo, mejora en los servicios para el público, actualización tecnológica escénica, puesta en valor y adecuación de instalaciones de las áreas de mayor valor patrimonial como la Sala Principal, el foyer y el Salón Dorado. Todo esto, además, bajo dos premisas fundamentales: la restauración conservativa y la conservación de la calidad acústica. Fue reinaugurado el 25 de Mayo de 2010, como parte de los festejos del Bicentenario.

Por último cabe mencionar que se celebraron dos (2) Congresos de arquitectura Moderna, el primero en Atenas y el segundo en Venecia, de los cuales se redactaron dos (2) Cartas Internacionales ${ }^{17}$ que se constituyeron como referentes de la concepción que se tendría a partir de entonces de las funciones básicas de las ciudades y de los principios sobre la salvaguardia de los edificios y su significado. Esto es, la definición de los conceptos de conservación, restauración edilicia y monumento histórico.

\footnotetext{
17 Carta de Atenas para la restauración de Monumentos Históricos: Adoptada en la Primera Conferencia Internacional de Arquitectos y Técnicos de Monumentos Históricos, Atenas, (1931) / Carta Internacional sobre la Conservación y la Restauración de los Monumentos y de los sitios de Venecia (1964). 
Debido a la trascendencia de estos documentos hasta la actualidad, es indudable que forman parte de los antecedentes arquitectónicos tenidos en cuenta para la intervención en cada una de las obras descriptas en el presente trabajo. (Esto será mencionado en los siguientes capítulos).

\subsubsection{Conclusiones Parciales}

Podría decirse que el final del siglo XIX y el comienzo de XX estuvieron marcados a nivel internacional por distintos sucesos políticos y sociales que, como en otros momentos de la historia de la humanidad, afectaron directamente la forma de concebir la arquitectura.

Refiriéndonos a nuestro país, sin dudas Francia y en especial París, se configura como el foco de atención tanto para los gobernantes como para la elite local, convirtiéndose en el paradigma del nuevo modo de proyectar las ciudades que se encuentran en pleno desarrollo. Así el academicismo predomina tanto en proyectos de la edilicia institucional como también en el ambito privado.

Los estilos borbónicos del primer renacimiento francés quedan atrás cuando se reivindica el primer Luis XVI. Se impone así un clasicismo elemental que lucha por recuperar los valores tradicionales puestos en crisis al multiplicarse las distintas corrientes heterogéneas.

Junto con la corriente inmigratoria y el modelo agro - exportador, el país comienza un incipiente crecimiento colocándose en las primeras décadas del siglo XX como lider regional. Este giro también se ve plasmado en obras de arquitectura como las mencionadas en el presente capítulo que fueron proyectadas durante este período y las cuales se vieron afectadas por la 1era guerra mundial.

Fue entre ésta y la 2da guerra mundial que los edificios pudieron concluirse cuando el comercio exterior ya se encontraba en baja y el desarrollo nacional comenzó a decaer.

Comparando al edificio tema del presente trabajo con los detallados anteriormente, esto es: el Palacio de Correo, el Palacio de Justicia, el Congreso Nacional y el Teatro Colón podemos encontrar varios puntos en común. En cuanto al lenguaje todos ellos responden a un estilo ecléctico academicista Francés. 
Cronologicamente se enlazan en un mismo período y se ven afectados por las mismas condiciones políticas y económicas que provocan la interrupción de las obras por largo tiempo. Por otro lado, los avances tecnológicos que se suceden en poco tiempo, generan la necesidad de cambios y actualizaciones en cada uno de los proyectos, que implican reformulaciones con distintos grado de complejidad, según el estado de avance que cada edificación había alcanzado hasta ese momento.

En cuanto a la morfología de los edificios, todos ellos se articulan como volúmenes exentos, acordes a la voluntad gubernamental, que éstos fueran masas murarias de gran porte y majestuosidad. Otras características comunes son; la composición axial de las fachadas con la generación de cuerpos entrantes y salientes, la disposición en altura de un basamento, un desarrollo y un remate integrado por mansardas con cúpulas o sin ellas, el uso de materiales nobles e importados, mientras eso fue posible por cuestiones económicas y políticas, etc.

En relación al tratamiento interior, en general se observa un hall de acceso de doble altura que actúa como nexo de vinculación entre la escala urbana y la escala propuesta por el proyecto. También la delimitación de ejes principales y secundarios con sus respectivos patios internos techados o a cielo abierto, que diferencian las áreas nobles respecto de los sectores de trabajo o depósitos.

A su vez se encuentra otro punto en común entre el Palacio de Correos y el conjunto edilicio motivo del presente estudio. Ambos se emplazan en terrenos ganados al río estratégicamente ubicados con cercanía al puerto, lo que muestra la importancia que eso representaba para la consolidación de la ciudad. La caracteristica de estos tipos de suelo trajo aparejada la necesidad de proyectar un complejo sistema estructural, que asegurara la estabilidad de los edificios mediante el asentamiento de bases a gran profundidad.

Cabe mencionar que todos estos edificios habian sido construidos con materiales nobles, de excelente calidad, muchos de los cuales fueron traídos del exterior. Pero debido a la falta de mantenimiento y a problemas de uso como la instalación de equipos de aire acondicionado sobre fachadas o el biodeterioro causado por la erosión atmosférica, la aparición de líquenes, microorganismos y guano de palomas, se encontraban en avanzado estado de deterioro. A fin de dar solución a estas patologías, en los últimos años fueron sometidos a intervenciones correctivas cuyo alcance incluyó procesos de puesta en valor, refuncionalización y actualización de sus instalaciones. 
Por último se cree importante mencionar que cada uno de ellos fue declarado Monumento Histórico Nacional salvo el Ministerio de Agroindustria, que solo cuenta con una protección estructural, siendo el pedido de declaratoria una de las instancias que este trabajo pretende retomar.

\subsection{Antecedentes Sociales}

\subsubsection{La Inmigración}

En 1862 el Congreso autorizó la contratación de inmigrantes para colonizar los territorios nacionales, específicamente las regiones externas a las provincias constituidas, que eran regidas desde Buenos Aires.

La Dirección de Migraciones, establecida en 1869, nombró agentes en Europa para reclutar colonos. Así, durante un breve período, a finales de la década de 1880, el gobierno subsidió pasajes en barco para los inmigrantes.

El proceso de inmigración fue de largo plazo y su periodización contempló tres grandes etapas: $1820-1880,1880-1914$ y $1914-1945$.

El primer período (1820 - 1880) ocurre cuando Argentina tras obtener su independencia de España a principios del siglo XIX, adopta una política de inmigración abierta y alentó a los extranjeros a elegir al país como propio. En estos años la inmigración hacia la América del Sur empezó a crecer, en algunos casos, apoyándose en las incipientes comunidades extranjeras que ya se habían instalado en la región en los tiempos coloniales.

La siguiente etapa (1880 - 1914) comprendió las décadas de auge de la inmigración europea, lo que sentó las bases del aumento poblacional en el ámbito bonaerense, al tiempo que participó del proceso de inserción de la región pampeana en el mercado internacional como exportadora de productos agropecuarios.

Finalmente, la tercera etapa (1914 - 1945) se caracteriza por las importantes oscilaciones en las corrientes inmigratorias, motivadas por las guerras mundiales, las crisis económicas en el plano internacional y las periódicas fases de inestabilidad del gobierno argentino, entre otros factores. 
Cabe aclarar que, en la década del 20' las cifras de inmigración disminuyeron cuando la política migratoria cambió dificultando el ingreso de extranjeros al país, ya que, debido al temor de las clases gobernantes a una revuelta de los recién llegados, se aumentó la seguridad en los puertos de desembarque. Por otro lado, en Europa, la productividad y los salarios aumentaron, representando una fuerte competencia.

La recesión económica de 1929 golpeó fuertemente al país con salarios que ya no lograban competir con los europeos, generando una baja significativa a la inmigración masiva desde Europa. Con excepción de un breve período posterior a la Segunda Guerra Mundial, la inmigración europea continuó descendiendo, siendo las comunidades italianas y españolas las dominantes hasta la década del 40'. En este lapso también se destaca la presencia de inmigrantes rusos y del ex Imperio Otomano.

En el mismo momento que se producían estos cambios respecto al proceso de la inmigración en nuestro país, el conjunto edilicio seguía creciendo ya que fue durante este período que se incorporó la mitad norte de la manzana y se construyó el segundo edificio en Av. Paseo Colón N922.

Resumiendo, se estima que entre 1870 y 1929 el país recibió más de siete millones (7.000.000) de inmigrantes, mayoritariamente de origen europeo. En el caso de los italianos llegaban buscando la oportunidad de dejar atrás su país empobrecido por la unificación de los estados italianos en los que prevalecía el desempleo y la superpoblación. Otro punto de atracción fueron los programas gubernamentales, los avances en el transporte y la oferta de mejores salarios. Todo esto producto del ingreso de la Argentina a una etapa de expansión económica, pacificación política y consolidación de las instituciones, que favoreció la llegada de inmigrantes, convirtiéndola durante años en uno de los destinos privilegiados.

\section{La legislación Inmigratoria Nacional}

Otorga igualdad de derechos y obligaciones a nativos y extranjeros. Así lo sostiene nuestra Constitución (Artículo 20):

..."Los extranjeros gozan en el territorio de la Nación de todos los derechos civiles del ciudadano; pueden ejercer su industria, comercio y profesión. No están obligados a admitir la ciudadanía, ni a pagar contribuciones forzosas extraordinarias". ... 
Durante la presidencia de Nicolás Avellaneda, en 1876, se sancionó y promulgó la ley №817 que consta de 121 capítulos, la mitad de ellos dedicados a la inmigración, y la otra mitad a la colonización.

En 1903, al sancionarse la ley $\mathrm{N}^{\circ} 4167$ "de venta y arrendamiento de tierras fiscales", quedó derogada la parte correspondiente a la colonización. Por medio de esta Ley se creó el Departamento General de Inmigración, dependiente del Ministerio del Interior; dándole al Poder Ejecutivo la facultad de nombrar agentes en aquellos puntos de Europa o de América que considerara convenientes para fomentar la inmigración para la República Argentina, los que tendrían como función desarrollar una continua propaganda, proporcionar gratuitamente informes a los interesados, certificar sobre la conducta y actitud industrial del inmigrante, intervenir en los contratos de transporte y, en algunos casos, pagar sus pasajes.

El Ejecutivo podía también nombrar oficinas de trabajo y de colocación que cumplieran la función de colaborar con el Departamento de inmigración de Buenos Aires y con las comisiones locales para atender los pedidos de profesores, artesanos, jornaleros o labradores, procurando condiciones ventajosas para los inmigrantes en el arte, oficio o industria a que prefiriesen dedicarse. Fomentando y facilitando, además, la instalación de estos inmigrantes en el interior del país.

La ley define como inmigrante a:

\footnotetext{
..." Todo extranjero jornalero, artesano, industrial, agricultor o profesor, que siendo menor de sesenta años y acreditando su moralidad y sus aptitudes, llegase a la república para establecerse en ella, en buques a vapor o a vela, pagando pasaje de segunda o tercera clase, o teniendo el viaje pagado por cuenta de la Nación, de las provincias o de las empresas particulares, protectoras de la inmigración y la colonización.” ... (Art. 12).
}

Todo inmigrante, siempre que: 
..."Acreditase suficientemente su buena conducta y su aptitud para cualquier industria, arte $u$ oficio útil", gozaba del derecho de ser alojado y mantenido a expensas del Estado durante los cinco días siguientes a su desembarco.”... (Art.45).

Además, el Poder Público se hacía también cargo de su traslado al lugar del país que eligiese como residencia. Por otra parte, cuando el inmigrante así lo desease, podía obtener ocupación a través de la Oficina del Trabajo.

En caso de dirigirse al interior del país, y si en el lugar de destino había Comisión de Inmigración, ésta debía otorgar al inmigrante alojamiento y alimentación por un plazo de hasta diez (10) días.

Dentro del contenido de los capítulos referidos a la Colonización se creaba la Oficina de Tierras y colonias, organismo encargado de centralizar la acción estatal. Además, la ley preveía diversos sistemas de colonización:

- Directa: Llevada a cabo por el Estado en territorios nacionales y en tierras cedidas por los gobiernos de provincia.

- Indirecta: a través de empresas particulares en tierras ya mensuradas y divididas, o en lugares que no hubieran sido explotados.

- Por iniciativa individual.

- De los gobiernos provinciales estimulados por el gobierno nacional.

- Por particulares amparados por el gobierno.

\subsubsection{Influencias sociales en la Arquitectura local}

Hacia 1820, por iniciativa de Rivadavia arribaron los primeros ingenieros franceses contratados especialmente por el nuevo gobierno. Aún cuando los proyectos en muchos casos no lograron concretarse estos técnicos fueron los pioneros de la arquitectura republicana.

El crecimiento poblacional y la corriente inmigratoria atrajeron la llegada de la mano de obra, tanto italiana como española y se vieron favorecidos también por la utilización de nueva tecnología y, especialmente nuevos requerimientos sociales de funcionalidad respecto de los pocos y sencillos tipos de fines del siglo XVIII.

Todo ello derivó en la innovación de los programas arquitectónicos, los tipos espaciales, ricos y eclécticos lenguajes. Así fue que durante la primera mitad del siglo se 
construyeron numerosos edificios monumentales, identificados como una adaptación francesa a la arquitectura neoclásica (según fue descripto en el punto 1.1.2).

Esta línea estaba representada por el academicismo Beaux Arts en sus diferentes acepciones estilísticas.

Por otro lado, y según se ha mencionado anteriormente, las oleadas inmigratorias en nuestro territorio con la llegada de los incesantes buques al puerto de Buenos Aires impactaron fuertemente generando un súbito aumento de la población. Lo que trajo aparejado el hacinamiento y la precariedad de viviendas, debido a que en ese momento los valores de las tierras llegaban a niveles inalcanzables.

Hacia 1852 se desató la fiebre amarilla, cuyo foco infeccioso se concentró principalmente en las inmediaciones de San Telmo, Barracas y Montserrat, lugares tradicionales de familias "patriarcas" que abandonaron sus mansiones para trasladarse a Recoleta y Barrio Norte. Aquellas casonas rápidamente encontraron un nuevo destino muy redituable para sus dueños que vieron en el aluvión inmigratorio una gran oportunidad productiva para sus viviendas abandonadas.

Los palacetes fueron transformados en palomares, con habitaciones sin ventanas y con un solo baño para cientos de personas.

El puerto durante el brote fue puesto en cuarentena y las provincias limítrofes impidieron el ingreso de personas y mercaderías procedentes de Buenos Aires. Pasado el brote de la fiebre amarilla, cuando se reabre el puerto, se inicia una etapa de ingreso masivo de inmigrantes al país por lo que surge una nueva problemática vinculada a la necesidad de contar con sitios provisorios para dar alojamiento a los extranjeros hasta su radicación definitiva.

\subsubsection{Respuestas políticas frente a la corriente migratoria del siglo XIX}

Los recién llegados gozaban de alojamiento gratuito, exención de pago de impuestos sobre sus posesiones y con el tiempo también recibieron el traslado sin costo en tren. Muchos de los primeros inmigrantes lograron una rápida movilidad social, aunque muy pocos pudieron adquirir tierras. 
Es así que surgen distintos proyectos con esta nueva temática inédita hasta entonces inspirados en el espíritu de darle cobijo a miles de inmigrantes, procedentes de todo el mundo. Siendo los albergues de inmigrantes las tipologías arquitectónicas mediante las cuales el estado procuraba dar una respuesta social a la problemática emergente. Cumpliendo además otras funciones como prestar servicios y distribuir a los flamantes residentes hacia distintos puntos del país.

El inicio de los albergues de inmigrantes estuvo relacionado con sitios como el Asilo de la Recoleta y el de la Chacarita de los Colegiales (1825), el Asilo de Corrientes $N^{\circ} 810$ (1857 - 1874) y el hospedaje de la calle Cerrito (1882 - 1888) con sus alojamientos complementarios.

En 1884 el cólera afectó nuevamente a la población y fue causa de la emigración a diferentes cuarteles y puntos de la ciudad. A partir de ese año funcionó en Retiro el Hotel de la Rotonda.

En el próximo capítulo se analizará la dimensión formal, espacial, funcional y morfológica de estos albergues, todo esto sin dejar de tener en cuenta el bien en cuestión.

\section{HOTEL DE LA ROTONDA}

Esta construcción conocida también como el "Hotel de Inmigrantes Redondo", de tres (3) pisos, casi circular, se presentaba desde el Río de la Plata como la primera visión de Buenos Aires. Se utilizó durante dos (2) décadas, convirtiéndose en la estructura de recepción más importante para el caudal migratorio europeo.

El hotel se amplió varias veces y funcionó hasta su demolición en el año 1908 cuando se inicia la construcción de la nueva estación de Retiro y el hotel de los inmigrantes. Hasta allí llegaban los inmigrantes en carros tirados por caballos a los que transbordaban ni bien abandonaban los botes.

Los dormitorios para mujeres y niños se habilitaron en la planta baja y los de hombres en el primer piso y a veces también en el segundo, cuando había mayor afluencia de inmigrantes. A esta edificación de la Rotonda se le adosó otra nueva, de forma rectangular y de una sola planta. En esta última sección estaban las cocinas, los comedores y los servicios sanitarios. En uno de los patios funcionaba la Oficina de Trabajo. 
Los inmigrantes podían permanecer gratuitamente en el Hotel por cinco (5) días. Vencido el plazo y de no mediar razones de fuerza mayor, estaban obligados a asumir los gastos de estadía.

\section{- EL HOTEL DE LOS INMIGRANTES}

Ubicado en un predio de seis (6) hectáreas del puerto nuevo de la Dársena Norte, el hotel fue iniciado por los constructores italianos Udina y Mosca, según proyecto del Ministerio de Obras Públicas y concluido por el alemán Kronffuss, tras superar varias dificultades.

Estaba conformado por un conjunto edilicio de diversos pabellones destinados al desembarco, colocación, administración, atención médica, servicios y alojamiento de los inmigrantes sin recursos, muchos con numerosa prole, a la espera del primer trabajo.

Los nuevos programas arquitectónicos fueron el resultado del modo en que se hizo más compleja la vida urbana planteada por la generación liberal a partir de la aplicación de los modelos europeos. Esto se mantuvo así por años, aunque este foco inmigratorio fue cambiando al producirse dos procesos posteriores:

$>$ La desaceleración de la migración transatlántica.

> La consolidación de Argentina como polo de atracción de las migraciones de países limítrofes debido al alto estándar de desarrollo humano y económico del país, en relación a los países de origen de estas poblaciones.

El hotel de inmigrantes que comenzó a funcionar en el año 1911, fue el que concentró el mayor volumen de inmigrantes. Esto se debió a su ubicación estratégica y cercanía respecto del punto de desembarco además de la capacidad de alojar a tres mil (3.000) personas.

En el siguiente cuadro se puede apreciar la distribución dentro de la ciudad de Buenos Aires de los distintos albergues y hoteles, los cuales estaban ubicados en su mayoría en las cercanías del puerto, próximos también al terreno en donde se construyó el conjunto tema de la presente tesis. (Ver Fig. $N^{\circ} 12$ ). 


\section{HOTELES DE INMIGRANTES EN BUENOS AIRES}

\section{1) $1810-1835$}

Primer "Asilo"u "Hotel de Inmigrantes", ubicado en las Instalaciones del antiguo convento de La Recoleta al costado de la lolesia del Pilar. Alli se alojaron, entre muchos otros los británicos y los alemanes llegados en 1825.

"Chacarita de los Colegiales lugar donde se

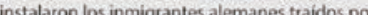
Heineen 1826.

\section{$2 \quad 1836-1854$}

Ante la llegada de un grupo de familias de las Islas Canarias, se habilitiaron provisoriamente las Cuando en 1836, arribo un segundo contingente de

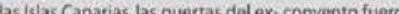
nuevamente abiertas

\section{$3 \quad 1855-1879$}

"Asilo" de la calle Corrientes 8, ubicado en Paseo de Julio - hoy Av. Leandro Alem-y la calle 25 de Mayo. (1857-1873).

En el dia de su inauguración fue alojado alliel primer contingente de inmigrantes de origen suizo.

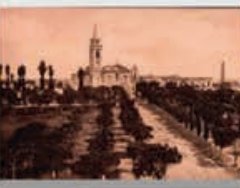

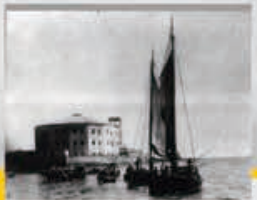

4

El Hotel de la calle Cerrito estaba emplazado en las instalaciones donde se desarrollo la Primera Exposición Industrial y Artistica ltaliana, Cerrito 1250 entre Arenales y Juncal (hoy Centro Argentino de Ingenieros).

Aquellas construcciones se ampliaron hasta la calle Libertad, prestó servicio hasta los primeros meses de 1888 .

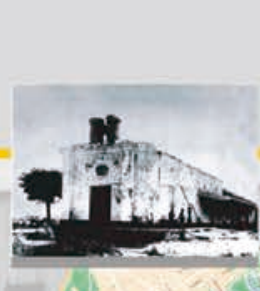

2
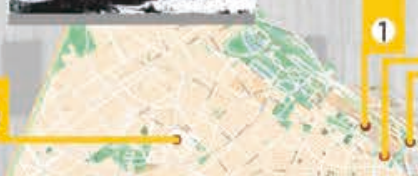

4

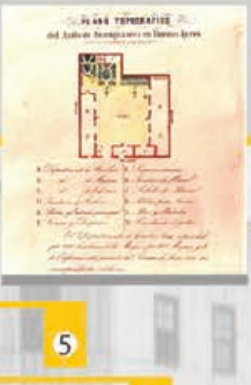

\section{5}

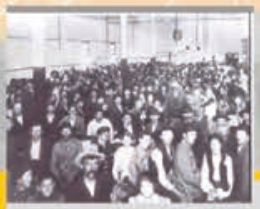

Hotel de "La Rotonda": Dado el crecimiento del aluvión inmigratorio, se hacia necesario contar con un hotel que permitiera la recepción de los grandes contingentes de inmigrantes que llegaban. Estaba emplazado en donde hoy se encuentra la estación del Ferrocarril Gral.Mitre- Retiro.
6

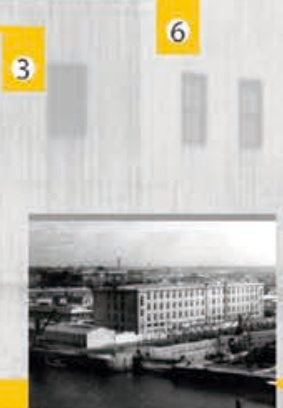

$6 \quad 1911-1953$

Hotel de Inmigrantes "definitivo" ubicado al costad del entonces Puerto de Buenos Aires -hoy Darsena Norte, era un gran complejo preparado para dar asistencia a los inmigrantes. Su imponente pabellón de alojamiento podia albergar a más de 3000 personas.
INMIGRANTES ARRIBADOS

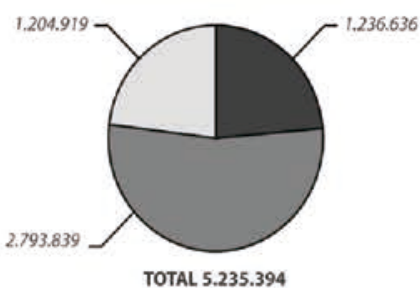

ALOJADOS

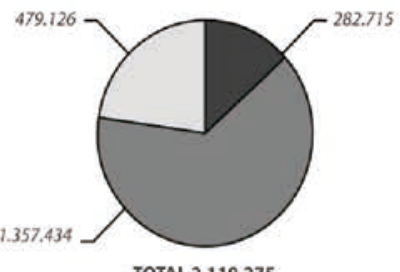

ALOJADOS S/ARRIBADOS

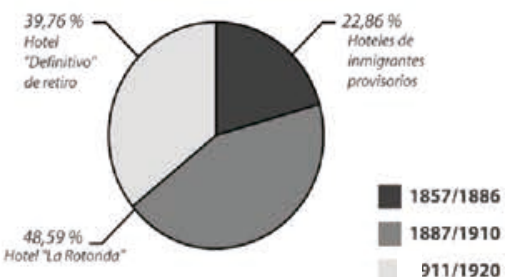

Fig. No 12.- Cuadro de ubicación de los Hoteles de inmigrantes desde el año 1810 y porcentaje de los alojados hasta $1920 .^{18}$

\footnotetext{
${ }^{18}$ Autor y fecha desconocidos - Ilustración a color-Recuperado de internet

http://www.migraciones.gov.ar/pdf_varios/museo/hoteldelinmigrantes.pdf - Fecha de consulta 26/06/19 Conjunto Edilicio Ministerio de Agroindustria de la Nación (ex Asilo Nocturno de la Capital) "Desarrollo de los instrumentos para la Conservación e Intervención del Patrimonio Arquitectónico. Hacia un Plan de Gestión".
} 


\subsubsection{Aspectos sociales en la consolidación de la ciudad moderna}

En torno a la década de 1860, Buenos Aires era ya una ciudad moderna, sede del poder económico debido al dominio del puerto y de la aduana.

En 1880 se convirtió en la Capital Federal del país. Lo hizo después de décadas de conflictos con la provincia, que no quería perder el territorio de la ciudad por motivos económicos y políticos. Ya contaba con tendido de red de agua corriente y crecía a pasos agigantados gracias al constante flujo inmigratorio europeo.

El desarrollo industrial comienza a tomar fuerza y se sumó como factor clave de la economía local. La planta urbana tradicional se transformó rápidamente, se consolidó el área central y los barrios fueron adquiriendo diferentes funciones y jerarquías. La población de mayores recursos fue abandonando su tradicional emplazamiento en la zona sur de la ciudad. Construyó sus nuevas residencias en la zona norte. Lo hizo en los barrios de Retiro, Recoleta y Palermo, debido a las deficientes condiciones de salubridad que presentaba el sur. Pero esta elección también se debió a las modas de la época, que privilegiaban los palacetes individuales.

La población siguió creciendo rápidamente alcanzando los seiscientos sesenta y cuatro mil (664.000) habitantes en 1895 con la inmigración como principal motor de este aumento.

Se aceleró el trazado de nuevas calles, el adoquinado en las ya existentes y la construcción de servicios hospitalarios y educacionales. Paralelamente, se incrementó la red de tranvías (primero a caballo y después eléctricos) para cubrir la creciente necesidad de movilidad, integrando paulatinamente a la ciudad en expansión. Los cambios en los medios de transporte jugaron históricamente un rol central en esta dinámica. 
Así, Buenos Aires se separó de su provincia. La Plata pasó a ser la sede de los poderes provinciales. El Gobierno Nacional se reservó el control del puerto, la administración de la justicia y la policía.

A partir de 1905 comenzó un paulatino proceso de incorporación del automóvil. Se hizo entonces necesaria la construcción de caminos adecuados. Mientras que por ese entonces apenas el $26 \%$ de la población del distrito federal residía a más de cinco (5) kilómetros de la Plaza de Mayo, hacia 1914 el 46\% se encontraba en esta situación, y la ciudad fue creciendo a dos velocidades. Los motivos fueron principalmente los hábitos culturales y la diferente calidad del transporte.

\subsubsection{Parámetros vinculantes con el conjunto edilicio en cuestión}

Según se mencionó anteriormente los albergues constituyeron el primer eslabón y nexo para el asentamiento de las corrientes inmigratorias en el país.

Analizando estos sitios (en especial el Hotel de la Rotonda y el Hotel de los Inmigrantes) en relación al conjunto edilicio tema central de la presente tesis, podemos encontrar varios aspectos en común tanto desde el punto de vista cronológico, como en lo referido a la ubicación geográfica, según se detalla a continuación:

\section{- Cronología:}

El primer punto en común se encuentra en la correspondencia temporal que compartieron parte de estos inmuebles.

Hacia los inicios de 1911, se inaugura el Hotel de los inmigrantes suplantando al Hotel de la Rotonda e instalándose como un gran complejo preparado para dar asistencia a los inmigrantes.

En simultáneo según un Decreto firmado en julio del mismo año, se designa la mitad sur de la manzana comprendida entre las calles Paseo Colón, Estados Unidos, Carlos Calvo y Azopardo para la construcción de un Asilo Nocturno para la Capital (actual Ministerio de Agroindustria). 
- Ubicación Geográfica:

Los primeros albergues se convirtieron rápidamente en los núcleos receptores ideales para los inmigrantes, debido a su proximidad respecto al puerto de Buenos Aires. Ya que apenas estos arribaban, luego de extensos viajes marítimos desde Europa, encontraban en tierra firme un sitio que cubría sus necesidades fundamentales.

La creciente expansión de la ciudad fomentó la iniciativa de modificar los límites costeros, rellenando parcelas con el fin de ganarle espacio al río y propiciar nuevos edificios de alojamiento cercanos al lugar de desembarcadero de los extranjeros.

\subsubsection{Conclusiones parciales}

Al iniciarse el proceso inmigratorio surge en primera instancia la necesidad de ampliar y sumar espacios a los hoteles ya existentes como respuesta a la problemática habitacional. Esto es debido al aumento exponencial de los recién llegados, que hacía que los alojamientos resultaran insuficientes y por ello se comienza a pensar en la construcción de nuevas edificaciones que lograran abastecer la fuerte demanda. Así es que el edificio en cuestión surge como respuesta a este dilema social.

En este contexto, la configuración espacial de la ciudad tuvo como característica la permanente expansión de sus límites y la consolidación de la ocupación, con la inmigración como principal impulsor de este crecimiento. 


\subsection{Antecedentes políticos y económicos}

\subsubsection{La configuración de la ciudad Capital}

Luego de décadas de luchas por establecer la sede de las autoridades nacionales y sucesos de violencia política que dieron como resultado el ascenso al poder de Julio A. Roca, se sanciona el decreto de federalización de Buenos Aires (1880) quedando la cuestión capital resuelta.

Ya que si bien, hacía casi dos décadas que el gobierno nacional funcionaba allí, la ciudad en un contexto de provisoriedad carecía de edificios que pudieran cumplir con la nueva demanda que la condición de capital requería.

La conciencia de que se estaba produciendo un pasaje de lo provisorio a lo permanente se evidenciaba asimismo, en la acción de la elite dirigente al ir transformando la trama urbana pequeña que mantenía su organización tradicional en un nuevo estado-nación. Asi es que irrumpen proyectos varios para gobierno, legislatura, justicia, biblioteca, museos, hotel de inmigrantes, sedes de policía, instalaciones militares, etc., a la vez que se inician obras para las infraestructuras de servicios, ferrocarriles, sanitarias, parques y el puerto. Estos proyectos requerían contar con el aval del congreso no solo a nivel presupuestario, sino también proyectual, debido a que la expansión demográfica producto de la inmigración y del crecimiento económico- producía un fuerte impacto en la cultura urbana que debía evaluarse detalladamente para convertir a Buenos Aires en un atractivo centro urbano, imagen de su incipiente progreso.

Aunque a esa altura la pregunta clave sobre dónde debía instalarse la capital argentina había sido definida, surgen a partir de ahora nuevos interrogantes:

¿Cómo debía ser la capital? ¿Cual debería ser la extensión y su trazado definitivo? ¿Que carácter debían tener sus edificios más representativos?

Es desde allí, en donde se reveen conceptos como la noción de carácter que hasta el siglo XVIII representaba la expresión exterior del destino del edificio y luego esta idea se diversifica. 
Por otro lado la figura de los palacios ligados a la belleza, la solidez y el poder, si bien en sus inicios se constituían como las viviendas de los reyes, a partir del surgimiento de las repúblicas se tranforman en edificios públicos. De allí es la expresión que dá título al trabajo: "Palacios sin reyes, Edilicia pública para la capital permanente", Buenos Aires 1880-1890 de la arqta Claudia Schmidt ${ }^{19}$, cuyo contenido se toma como referencia para la elaboración del presente capítulo.

La imagén del "palacio sin reyes" se impone como el modelo elegido por técnicos y políticos para comenzar a delinear la nueva capital y darle carácter nacional. Mientras se termina de construir la Casa de Gobierno en su ubicación original y se convierte en la primera manifestación de respeto hacia el sitio histórico, se inician las obras de edificios significativos en torno a una diagonal virtual que parte desde allí y que vinculará paulatinamente la Plaza Lavalle y la Escuela - Palacio Petronila Rodríguez, en la dirección noroeste.

Esta deliberada distribución dentro de la trama de la Capital, haría evidentes los roces que el estado mantenia con la Iglesia. Se reafirmaría así la zona más moderna, con la localización del Palacio del Congreso Nacional y el traslado del tanque de provisión de aguas corrientes para convertirlo en un palacio, éste último como muestra suprema del concepto de objeto que se separa de su destino, ya que la fachada no tenía una lectura correlativa en su interior.

Simultáneamente, otro polo de atracción se estaba formando tras reunir en un mismo sector de la ciudad cuatro edificios públicos: una Escuela Primaria, un Museo, el Palacio de Justicia y el Teatro Colón. Todos proyectados por Tamburini y en quien Roca habia depositado sus expectativas.

Así durante los primeros años de su gestión, se fue delineando un posible programa de edificios públicos, aunque sin un plan integrador y en un contexto en donde todavía imperaba el eclecticismo.

\footnotetext{
19 Schmidt C. "Palacios sin reyes, Edilicia pública para la capital permanente", Buenos Aires 1880-1890 -Tesis doctoral, diciembre 2004.
} 
Por otro lado el ensache de la capital, sumando los pueblos de Flores y Belgrano (1887) implicó, además del trasfondo político, la extensión de sus límites y la posibilidad de repensar la ciudad en términos territoriales.

El "asiento de las autoridades" en torno a la sede de los tres poderes republicanos, se terminaría de consolidar a finales de la década del ochenta, con nuevos edificios ligados a procesos de modernización en el contexto de la construcción del estado -nación. Es a través de la decisión de la reubicación del Palacio del Congreso, la nueva sede para el Correo en cercanías del Puerto y el traslado del Teatro Colón, que se despeja el entorno de la Casa de Gobierno, ubicando una pieza singular como remate de la Avenida de Mayo.

Esta capacidad de transmutación de sitios en la ciudad y la compra de terrenos que luego serían vendidos o que modificarían su función, son recursos por entonces puestos a disponibilidad que eran acompañados de la creciente prosperidad económica. Por otro lado, la alta prioridad que se le asignó a la arquitectura escolar relegó a otros temas vinculados como el de los museos, que no tendría un lugar prioritario en la capital por muchas décadas más y constituyó una buena parte del conjunto de los palacios sin reyes que representaron el "asiento de las autoridades".

La década de 1890, indicará un paréntesis en la producción de edilicia pública, aunque continúa el debate. Los palacios se irán completando y el estado desarrollará su nueva imágen, combinando la primera expresión republicana con una más clara búsqueda de la representación de un estado - nación moderno.

Es cuando el desarrollo industrial, tomó fuerza y se sumó como factor clave de la economía urbana. La ciudad adquiere una nueva configuración en función de la reubicación de su población. Asi es que los sectores de mayores recursos se desplazan ocupando la zona norte. Los barrios adquieren nuevas categorías y escalas dentro de la sociedad.

Conjunto Edilicio Ministerio de Agroindustria de la Nación (ex Asilo Nocturno de la Capital) 


\subsubsection{Proceso de expansión de la actividad agrícola- ganadera}

Las primeras décadas del siglo XIX estuvieron marcadas por el inicio de la ruina de las economías interiores, las guerras civiles y el condicionamiento de la gestión agraria según el criterio de los gobernantes de turno.

En un principio, se impuso una práctica liberal, que favorecía el libre cambio, en perjuicio de las economías interiores. Luego siguió un período proteccionista asumido por el federalismo y en particular por el gobierno de Rosas, que permitió una expansión de la actividad agropecuaria, incorporando nuevos cultivos a la producción, auspiciando el aumento de la superficie sembrada y propiciando la siembra de otros cereales. Es esta una de las primeras políticas agrícolas aplicadas con un sentido nacional y en beneficio del país.

Los gobiernos que se sucedieron luego de 1853, demostraron un enorme interés por el desarrollo de la ganadería lanar, lo que provocó un verdadero auge de esta actividad. Durante la presidencia de Sarmiento (1868-1874) se crea por Ley, el Departamento Nacional de Agricultura, dependiente del Ministerio del Interior y se plasman los fundamentos de una agricultura moderna capitalista, con objetivos claros, capacitación del personal y profundización del carácter científico de la actividad.

En pocos años el país se convirtió en uno de los principales exportadores de cereales, como así también de carnes, y recibió el mayor porcentaje de las inversiones Inglesas hacia América latina, las que se dedicaron a la extensión del ferrocarril, a la instalación de frigoríficos y empréstitos a los gobiernos.

En relación a lo mencionado, hacia el año 1872 el entonces Director del Departamento Nacional de Agricultura Ernesto Oldendorff expresaba en las Memorias Ministerio de Agricultura, Buenos Aires: ${ }^{20}$

"Pocos países existen en que la naturaleza haya sido más pródiga y en que la agricultura en sus diversos ramos prometa, a no dudarse, un porvenir más halagüeño que en la República Argentina".

\footnotetext{
${ }^{20}$ Memorias Ministerio de Agricultura, 1872. Archivo General de la Nación (AGN) del Ministerio del Interior, Buenos Aires, Argentina.
} 
A través de sus palabras podemos inferir cual era la situación del país, las riquezas que albergaba y el futuro alentador que, por entonces, se creía vislumbrar.

Años más tarde, la primera presidencia de Julio Roca (1880 - 1886) marca en el campo económico la época de oro del sistema liberal, el desarrollo de recursos naturales y la atracción de los capitales extranjeros, afianzando un modelo primario exportador de tinte agropecuario.

Con la crisis del 90' caen las acciones, el poder adquisitivo del salario disminuye, la emisión de billetes es indiscriminada y el crédito se restringe.

Luego de varios vaivenes políticos y cambios de mando es elegido nuevamente Julio Roca como Presidente de la República (1898 - 1904). Su segundo mandato coincide con el final de la crisis del 90' y el inicio de una curva ascendente en la economía.

\subsubsection{Parámetros vinculantes con el conjunto edilicio en cuestión}

Fue durante este período (1898), que el entonces presidente creó el Ministerio de Agricultura, sobre la base del antiguo Departamento de Agricultura instaurado por Sarmiento en 1871, siendo su titular el doctor Emilio Frers quien asumió como primer Ministro de Agricultura de la Nación.

El mismo que ese año, pronunciando su discurso ante la Honorable Cámara de Diputados, afirmaba:

(...) "Yo no puedo saber cuáles serán los destinos que el futuro reserva a este Ministerio...espero que, dentro de un cuarto de siglo, cuando se recuerde la inspirada y patriótica iniciativa de este Congreso, se podrá decir de ella que contribuyó poderosamente a realizar los sueños, entonces fantásticos y acaso utópicos, de los que en 1810 se propusieron fundar una nación poderosa, rica y feliz!" 21

\footnotetext{
${ }^{21}$ Memorias Ministerio de Agricultura, 1898 Memorias Ministerio de Agricultura. Archivo General de la Nación (AGN) del Ministerio del Interior, Buenos Aires, Argentina.

Conjunto Edilicio Ministerio de Agroindustria de la Nación (ex Asilo Nocturno de la Capital)
40 "Desarrollo de los instrumentos para la Conservación e Intervención del Patrimonio
Arquitectónico. Hacia un Plan de Gestión".
} 
Continuando con el mismo espíritu positivista de Ernesto Oldendorff quien años atrás había augurado para el país un futuro prometedor, Frers también refiere al mismo como un lugar de plenas posibilidades de progreso.

Mientras tanto la red ferroviaria crecía en todo el país, la producción agrícola se desarrollaba en forma sostenida, el flujo de inmigrantes no cesaba y los resultados de la incorporación de mejoras en la producción ganadera y en el proceso de faenamiento alcanzaba rápidos resultados exitosos.

Cabe considerar que el organismo, como principal área técnica agraria del país y con una concepción estratégica de explotación de los recursos naturales, comprendía entre sus funciones la exploración geológica de detección de napas de aguas subterráneas, las actividades mineras y petroleras. Por eso, fue personal de la División de Minas, Geología e Hidrología del entonces Ministerio de Agricultura, quien perforó por primera vez un pozo petrolero en Comodoro Rivadavia (1907).

\subsubsection{Conclusiones Parciales}

Como se ha descripto una parte importante de las transformaciones que atraviesa Buenos Aires a partir del año 1880 están ligadas a una expansión económica sin precedentes y a la conformación de una capital permanente.

Desde esta perspectiva, se puede comprender la preocupación de los políticos y proyectistas en esta primera etapa, al procurar conformar un carácter público todavía bajo un confuso formato y en permanente búsqueda, tomando la lógica del palacio como modelo de esa imágen que se pretendía alcanzar, siempre y cuando los nuevos edificios portaran un alto grado de representación simbólica.

Al decir de la arqta Schmid, en su trabajo ya mencionado:

"Si bien es evidente que las búsquedas expresivas, estéticas y simbólicas no estaban del todo claras, se puede encontrar un denominador común: el de la apelación a la figura del palacio como la expresión republicana de la nueva presencia del Estado en términos institucionales". 
El ensanche, la regulación de los límites de la capital y la fundación de La Plata terminaron con un largo período de enfrentamientos políticos. A su vez ligados a cambios profundos en una sociedad que aún se encontraba en plena formación y que se incrementaría sustancialmente a partir del proceso de inmigración masiva.

En este contexto se fueron respondiendo los interrogantes iniciales acerca de cómo debía ser la capital que pasó de provisoria a permanente, cuales serian ahora sus nuevos límites y como estaría conformado su trazado definitivo, delimitando los ejes posibles de desarrollo y proyectando sus diagonales. Determinando el carácter que debían tener sus edificios más representativos en función de encontrar una identidad propia y haciendo hincapié en la localización de esos principales monumentos para convertirlos en focos de articulación urbana. A la vez buscando un equilibrio en la tensión entre los edificios y los espacios abiertos que los preceden.

Estas propuestas se vincularían también con otro tipo de emprendimientos como por ejemplo la construcción de las escuelas - palacio. Siendo todos ellos parte de un mismo plan del estado, en este caso a nivel educacional, procurando involucrarse en una nueva formación de enseñanza laica y popular, en vías del crecimiento al que la Nación aspiraba llegar.

\subsection{Conclusiones}

Por todo lo antes relatado podemos decir que el Asilo Nocturno de la Capital, emerge como una masa muraria de dimensión monumental, que sobresale de un entorno que por entonces mantenía una escala urbana acotada. Lo hace a través de una mirada ecléctica, dirigida hacia Europa, tal lo ocurrido con el resto de los edificios responsables de la constitución de la Capital. Compartiendo los mismos criterios de austeridad, monocromía y ausencia de ornamentaciones, pero cargados de significaciones. Una arquitectura basada en el concepto del Palacio y asociada a la idea del progreso que se pretendía alcanzar. 
La ubicación de la obra coincide con lo que entonces representaba el límite urbano hacia donde desembocaba en el Río de la Plata, con proximidad al puerto y como punto estratégico en los ya mencionados ejes urbanos de articulación de la ciudad.

En relación al cambio de destino que sufrió el edificio antes de su inauguración (tema que será abordado en el capítulo siguiente) podría pensarse que se debió a la conjunción de diferentes acontecimientos históricos entre ellos: aspectos sociales, políticos y económicos.

Por un lado el contexto social marcado por la desaceleración de la inmigración ocurrida entre la aprobación del proyecto y su terminación, que provocó la disminución en la cantidad de recién llegados al país.

Por otro lado el crecimiento de las actividades agrícolas - ganaderas a nivel nacional y las nuevas actividades productivas, hacían prever la urgencia de contar con un edificio propio acorde a las necesidades emergentes del sector, centralizando así las actividades que se comenzaban a emprender y buscando fomentar un crecimiento rápido y sostenido de nuestra economía, aprovechando los recursos naturales para mostrarle al mundo lo que éramos capaces de hacer.

Con el transcurso del tiempo el conjunto se fue modificando y ampliando conservando siempre la función que lo caracterizó desde el momento de su inauguración, cambiando únicamente su denominación pasando reiteradamente de ser Secretaría a Ministerio de Agroindustria hasta hoy.

Según se verá más adelante solo los últimos trabajos de intervención edilicia, se realizaron respetando los principios fundamentales planteados en los congresos de arquitectura internacional (ya mencionados en este capítulo), en lo referente a la conservación y restauración de sitios históricos. Esto es importante de destacar ya que nuestro país tardaría años en hacerse eco de las cartas y manifiestos allí formulados, mientras que en otras regiones se implementaron mucho más tempranamente. 


\section{Capítulo II.- PROYECTO ORIGEN Y SUS TRANSFORMACIONES}

Preguntas claves:

¿Cómo surgió el proyecto inicial en sus definiciones arquitectónicas y urbanas?

¿Cuáles fueron las incorporaciones y/o modificaciones que tuvo el conjunto con el paso del tiempo? ¿Qué influencia tuvieron?

\subsection{El proyecto original}

\subsubsection{Función / Programas}

2.1.2. Análisis Formal y Morfológico (Forma/ Materia/ Color/ Llenos y Vacíos)

2.1.3. Parámetros vinculantes con otros Hoteles de inmigrantes de la época

2.1.4. Conclusiones parciales

\subsection{Desarrollo histórico}

2.2.1. Nuevo destino de la obra. Modificaciones formales, funcionales y de uso de los espacios

2.2.2. Transformaciones identificadas a lo largo del tiempo

2.2.3. Conclusiones parciales

2.3. Marco socio - político-cultural de las transformaciones y adecuaciones

2.3.1. Conclusiones parciales

\subsection{Conclusiones}




\subsection{El proyecto original}

\subsubsection{Función / Programas}

Según el Decreto firmado en julio del año 1911, se destina la mitad Sur de la manzana comprendida entre las calles Paseo Colón, Estados Unidos, Azopardo y Carlos Calvo para la construcción del Asilo Nocturno para la Capital Federal, que daría albergue a 100 mujeres, 25 niñas, 45 niños y 370 hombres, en total a 540 personas.

El proyecto original del primer edificio fue pensado, por la Dirección General de Arquitectura del entonces Ministerio de Obras Públicas y sus planos estudiados de acuerdo a indicaciones formuladas por el Señor Presidente de la Comisión de Asilos y Hospitales Regionales. Los mismos se aprobaron el 21 de septiembre de 1912 y se adjudicó a los señores Andrés Vanelli e hijos.

Dado que el predio estaba enmarcado dentro del perímetro de terrenos ganados al Río de la Plata cuando se ejecutaron las obras del puerto de la Capital, el esquema de su cimentación estaba conformada por pozos y arcos.

El edificio fue proyectado con una planta de $52 \times 52 \mathrm{mts}$, un semi subsuelo, tres pisos y una mansarda. Preveía una fachada con un acceso central principal jerarquizado por un pórtico saliente, compuesto por tres arcos Tudor, sostenidos por pilares decorados con pilastras rectas y curvas intercaladas, rematadas por un capitel de estilo corintio. Atravesado el ingreso y ya en su parte interior, una bóveda de crucería con nervaduras, y detalles neo medievalistas.

La distribución en las distintas plantas contemplaba sectores destinados a oficinas, comedores, baños, peluquerías, depósitos varios, casita para el administrador, una enfermería, talleres y escuela.

Respecto a las cocinas, lo previsto en el proyecto de Asilo Nacional Nocturno para la Capital Federal ${ }^{22}$ presentado al Señor Ministro de Obras Públicas Ezequiel Ramos Mejía, era lo siguiente:

\footnotetext{
${ }^{22}$ Ministerio de Obras Públicas, Dirección General de Arquitectura. Buenos Aires- Año 1912.
} 
..." A las obras así previstas debe agregarse la instalación de la cocina, que podrá hacerse con una cocina económica tan solo, - pues que no se da de comer en estos asilos - la instalación del lavadero y la de la caballeriza..." (Pág.№2)

Se preveía inicialmente la construcción de un único edificio para albergar a trescientas (300) personas, pero luego se decidió ampliar su capacidad y complementarlo además con dos edificios anexos destinados a lavandería y cocheras. Estos volúmenes de menor tamaño se ubicaban en la parte posterior, completando el sector sud - este del predio. (Ver Fig. No 13 y 14).

M.O.P.

- DIRECCION GENERAl. DE ARQUTTECTURA .

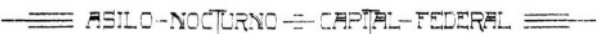

SOTANO

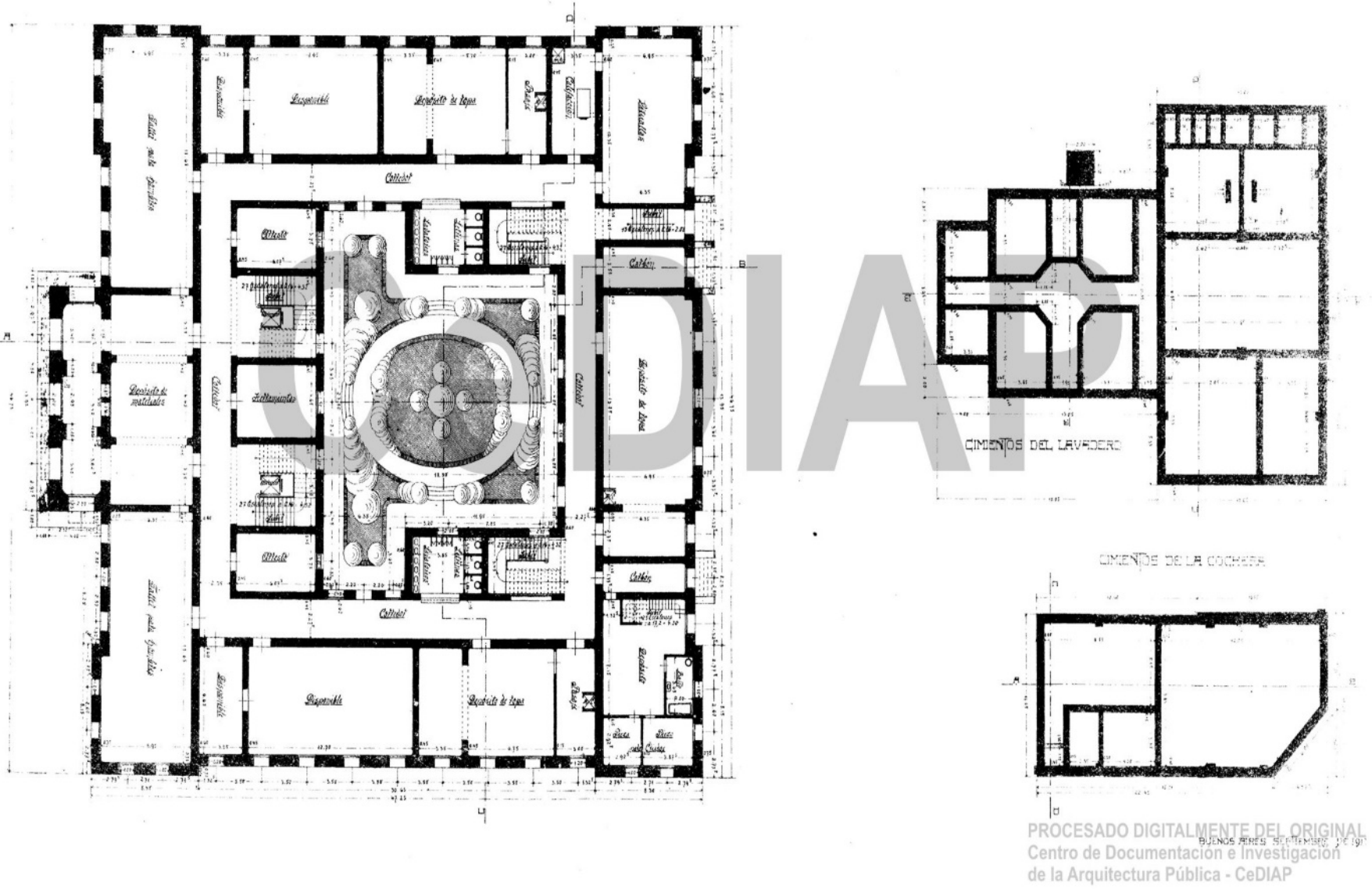

Fig. NN 13.- Plano de la planta baja y los edificios anexos (Digitalizada por el CeDIAP) 


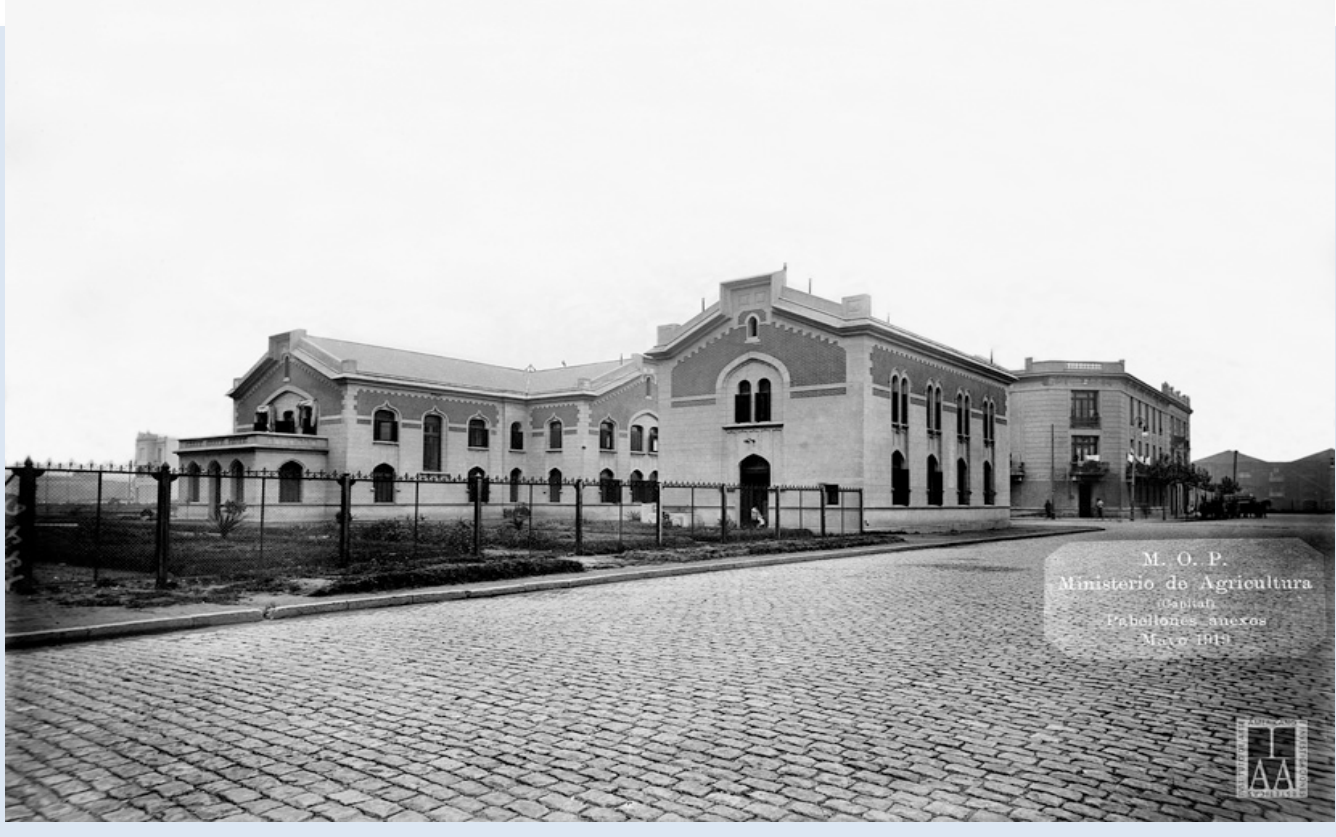

Fig. № 14.- Fotografía de los anexos, blanco y negro (Digitalizada por el CeDIAP).

Si bien los tres (3) cuerpos inicialmente eran independientes entre sí, el tratamiento de fachadas de cada uno de ellos hacía verlos como un conjunto consolidado. Verificable en el cromatismo de los materiales de construcción, entre ellos, destacables a simple vista el ladrillo rojo, la pizarra y la piedra. Años más tarde los anexos fueron unificados.

Los trabajos fueron iniciados demoliendo un volumen existente del cual no se tienen registros salvo lo que figura en el Pliego de estipulaciones para la construcción del edificio, perteneciente al documento antes mencionado:

..." El contratista demolerá todo el edificio viejo existente, despejando a la vez completamente el terreno de obras o materiales inútiles.

La demolición de partes de edificio viejo que deban prestar servicios provisionales o las paredes medianeras o que sustenten obras subsistentes, serán realizadas con toda precaución, apuntalando donde fuera menester y recabando previamente la conformidad de la Inspección..." (Título VII- Disposiciones varias- Art. 42- Demolición del edificio viejo, página 29).

El conjunto edilicio proyectado debía construirse en un plazo entre un año y medio hasta dos, sin embargo el proceso de su ejecución fue lento y con interrupciones, atravesando 
varios cambios de gobierno y la 1era guerra mundial de por medio hasta concluirse en el año 1919.

Finalizada esta etapa, años más tarde se inició la construcción del segundo edificio casi idéntico al volumen principal preexistente, separado de éste por una calle interna con acceso desde la Av. Paseo Colón.

Si bien esta incorporación y otras que continuaron años más tarde serán detalladas posteriormente, dado que la lectura exterior de ambos volúmenes es casi identica se toma al conjunto como referencia para el siguiente análisis formal y morfológico.

\subsubsection{Análisis Formal y Morfológico (Forma/ Llenos y Vacíos/ Materialidad/ /lenguaje / Color)}

El análisis formal y morfológico deriva entonces de lo observado, de la envolvente de los edificios principales, hacia el núcleo central de cada uno de ellos, contemplando los siguientes aspectos: la forma, los llenos y vacíos, la materialidad, el lenguaje y el color.

El objeto de este análisis es el de establecer cuáles fueron los distintos parámetros que se tuvieron en cuenta para la construcción de los mismos. Ya que, el enfoque adoptado en las decisiones proyectuales radica el uso que se le pretendía dar a cada espacio y como era concebido el conjunto para la sociedad de la época.

a) FORMA: El conjunto edilicio está conformado principalmente por dos (2) construcciones de volumetrías visualmente gemelas, pero planimétricamente diferentes.

Cada una de estas estructuras responde a un esquema tradicional de planta cuadrada, con un patio central, rodeado por corredores de circulación horizontal y vertical. La composición utiliza un eje de simetría sobre el volumen de acceso saliente central, que divide a cada edificio en dos mitades idénticas, siguiendo el esquema de alas laterales y volúmenes esquineros, levemente exentos. (Ver Fig. N $\left.{ }^{\circ} 15\right)$. 


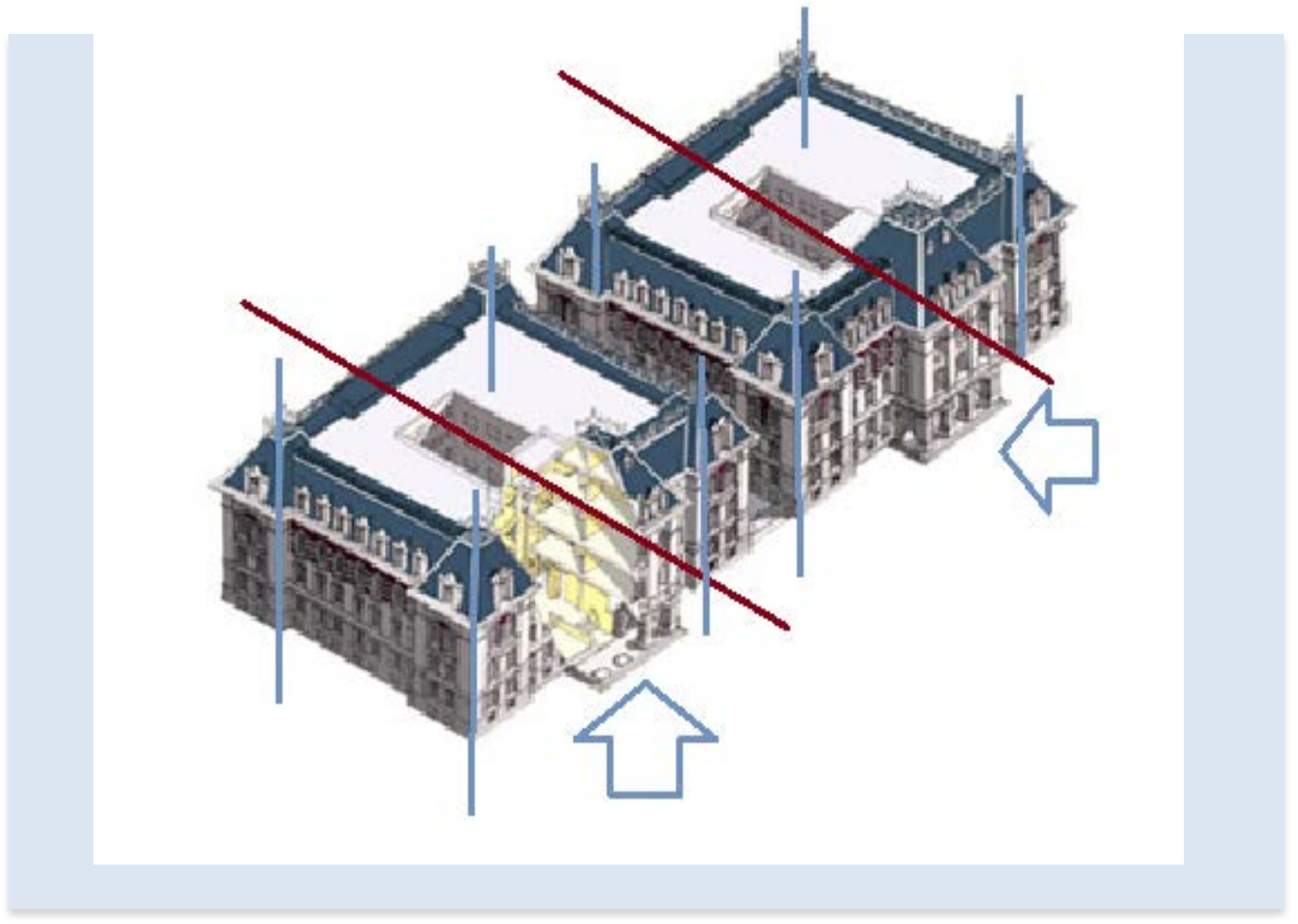

Fig. No 15.- Axonometría del conjunto edilicio desde la actual Av. Paseo Colón (Autor desconocido)

El proyecto original preveía una distribución espacial interior que se caracterizaba fundamentalmente por un esquema de planta libre. Esa permeabilidad de la planta fue lo que facilitó su adaptación al nuevo uso (Ver Punto 2.2.1 - Modificación del destino de la obra) sin que esto conllevara cambios profundos en los espacios, resultando ser flexibles a los nuevos requerimientos.

b) LLENOS Y VACIOS: Los accesos principales ubicados sobre la Avenida Paseo Colón se ven jerarquizados por un pórtico saliente de tres (3) arcos Tudor, sostenidos por pilares, los cuales están decorados con pilastras rectas y curvas intercaladas, rematadas por un capitel de estilo corintio. Su parte interior está compuesto por una bóveda de crucería con nervaduras, generando un hall semicubierto.

Las esquinas también se encuentran diferenciadas, en menor escala con respecto a los accesos, con entrantes y salientes, integrando los laterales respecto del resto del conjunto.

Los volúmenes se alzan como cuerpos de formas básicas cerradas que se abren hacia sus propios centros integrados por los patios internos que conforman las 
áreas de expansión y también dialogan con el resto del conjunto a través del jardín que se articula como nexo de estos.

Esta dinámica de llenos y vacíos muestra una escala monumental, pero a la vez dinámica, hacia la ciudad y genera una escala más acotada e intimista hacia el interior de cada uno de los edificios.

La variedad de superficies, permite deducir que el proyecto no buscaba una lectura metódica y plana de los edificios, sino todo lo contrario un juego de luces y sombras, rectas y contra rectas brindando la idea de un conjunto en constante movimiento.

c) MATERIALIDAD: el conjunto edilicio está compuesto estructuralmente por muros con una terminación exterior tipo símil piedra, hormigón de piedra para los pozos de cimentación y hormigón armado para los entrepisos. Otros materiales empleados son: pavimentos entarimados, mosaicos calcáreos para pasillos de circulación y mármoles de carrara para solías y escalinatas. Para las carpinterías exteriores, tanto en las calles perimetrales como las interiores con vista hacia los jardines, se optó por madera de cedro y marcos de algarrobo, mientras que para las aberturas interiores se eligieron contramarcos de pino.

Los materiales utilizados fueron en su mayoría importados de Francia y las tareas ejecutadas por profesionales u operarios formados en su mayoría en Europa.

Podría decirse entonces que la materialidad adoptada permitió darles un estilo robusto, simple y a la vez de jerarquía, que mostrara la influencia de las tendencias europeas en el país y el impacto que estas generaron.

El conjunto edilicio se suma así al resto de los inmuebles de la ciudad de Buenos Aires que apelaban a generar un impacto visual en la población local y extranjera, mostrando un país en constante crecimiento.

d) LENGUAJE: En cuanto a la ornamentación arquitectónica, es de estilo neogótico, con algunos retoques vinculados al estilo Tudor, y otros renacentistas.

El predominio del almohadillado acompaña el desarrollo de los pisos centrales de los edificios, remarcando la horizontalidad de las fachadas que se ven armonizadas con los ritmos verticales de las carpinterías. (Ver Fig. $\left.N^{\circ} 16\right)$. 


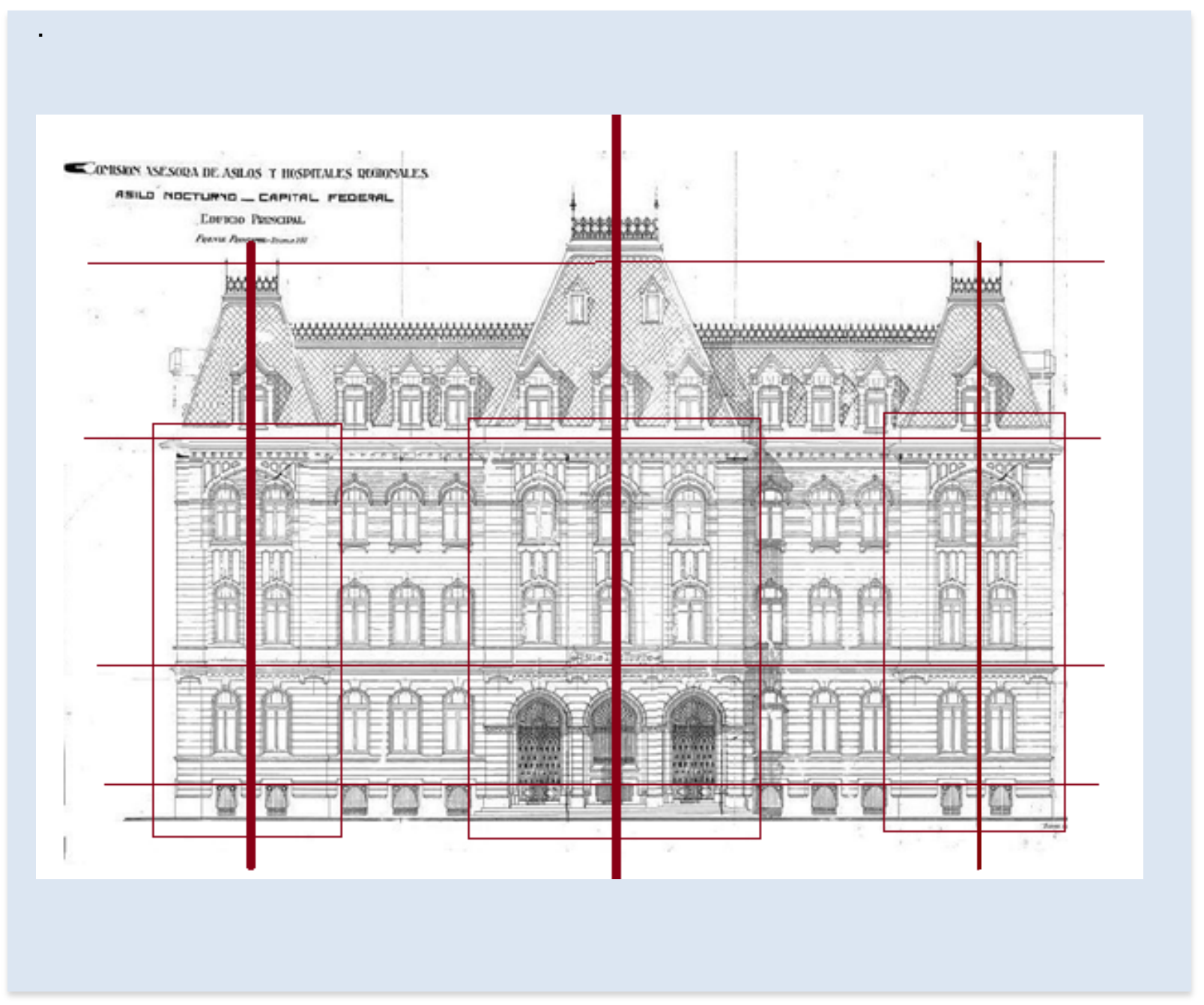

Fig. N¹6.- Fachada principal del edificio de Paseo Colon $N^{\circ} 982$ (Plano año 1911, digitalizado por el CeDIAP). -

En el remate de los edificios las cresterías con dibujos calados y pináculos envuelven todo el recorrido de las terrazas en sus cuatro frentes.

Es así que el lenguaje arquitectónico presenta una construcción contundente, de carácter propio.

e) COLOR: Los edificios muestran un diseño de las fachadas basado en el uso expresivo de los materiales de construcción expuestos aquí en sus colores naturales.

Entre los colores más significativos del conjunto se destaca el ladrillo rojo en el tercer piso y las pizarras grises tipo inglesas de las cubiertas de ambos edificios. Estas 
techumbres se encuentran separadas del piso inferior por medio de una cornisa, sostenida por ménsulas, la cual unifica los volúmenes dándoles una unidad plástica.

Las fachadas presentan una lectura armónica, casi monocromática con pequeños resaltes de color a medida que crecen en altura.

\subsubsection{Parámetros vinculantes con otros Hoteles de inmigrantes de la época}

Según lo mencionado en el capítulo I (pto 1.2.3 respuestas políticas frente a la corriente migratoria del siglo XIX), los albergues de inmigrantes se constituyeron como la respuesta política a la problemática social emergente producto de la inmigración, así sucedió con el hotel de la Rotonda y el hotel de los Inmigrantes.

A continuación, se realizará un análisis morfológico de ambos y se establecerá si existe alguna vinculación con los edificios tema de la presente Tesis.

HOTEL DE LA ROTONDA conocido también como "Hotel de Inmigrantes Redondo"

Se encontraba en algún lugar no identificado de la ribera y fue construido para recibir, prestar servicio, alojar y distribuir a los miles de inmigrantes que, procedentes de todo el mundo, arribaban a nuestro país.

A la primera edificación con forma poligonal, se le adosó posteriormente una planta de forma rectangular, integrada por las cocinas, los comedores, la administración, los patios y los servicios sanitarios. (Ver Fig. № 17).

Funcionó hasta su demolición en 1911 cuando se inicia la construcción de la nueva estación de Retiro y estaba en obra el hotel de los inmigrantes. 


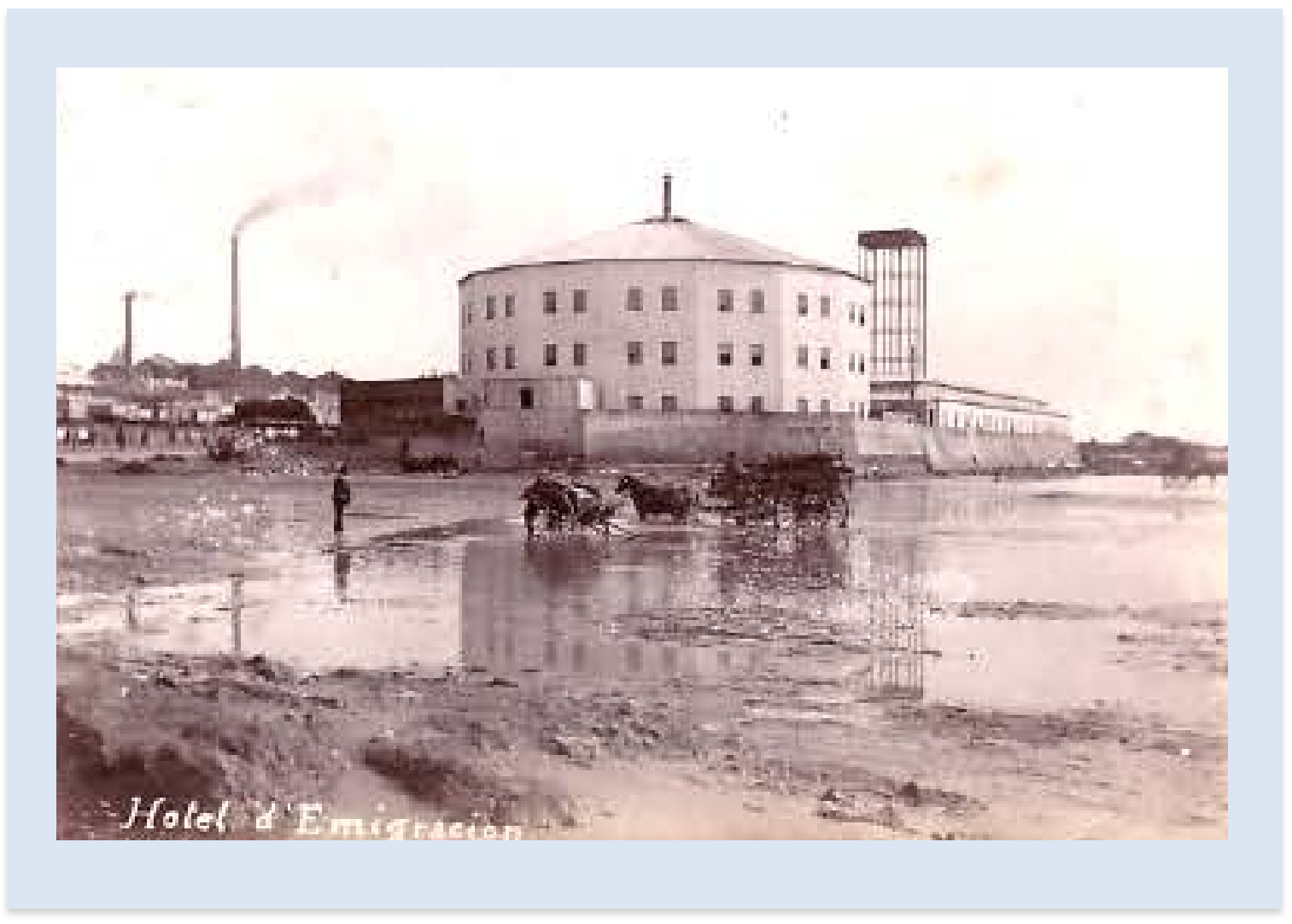

Fig. No 17.- Imagen fachada principal "Hotel de la Rotonda"-Año 1887- Buenos Aires ${ }^{14}$

\section{- HOTEL DE LOS INMIGRANTES}

Según lo que consta en la página de la Dirección Nacional de Migraciones, el complejo estaba conformado por diversos pabellones destinados al desembarco, colocación, administración, atención médica, servicios, alojamiento y traslado de los inmigrantes. ${ }^{23}$

El edificio principal estaba distribuido en tres (3) pisos, con dormitorios para mujeres y niños en la planta baja y para hombres en el primer piso y a veces también en el segundo, cuando había mayor afluencia de inmigrantes. Estos dormitorios estaban amueblados con cuchetas altas y bajas.

Hasta allí llegaban los inmigrantes en carros tirados por caballos a los que transbordaban ni bien abandonaban los botes.

23 http://www.migraciones.gov.ar/accesible/indexN.php?hotel, Galería de Fotografías del Museo de la Inmigración Recuperado de internet $(26 / 04 / 19)$ 
La obra se llevó a cabo siguiendo el orden que la necesidad demandaba. En primer lugar, el desembarcadero, luego la oficina de trabajo, la dirección, el hospital, y por último el hotel. Mientras se ejecutaba la construcción, los inmigrantes comían y dormían en el antes mencionado hotel de la Rotonda, a pocas cuadras de la nueva edificación. De esta forma, una vez desembarcados, se iban caminando hasta allí, donde eran alojados.

Cada uno de los edificios que integraban el flamante hotel cumplía una función determinante en la organización general de las tareas vinculadas a la inmigración:

- DESEMBARCADERO El acto de desembarco consistía en el abordaje de una junta de visita a cada barco que llegaba, con el objeto de constatar la documentación exigida a los inmigrantes, de acuerdo a las normas, y permitir o no su desembarco.

El control sanitario se realizaba a bordo, por un médico asignado a tal fin constatando que los inmigrantes no estuvieran afectados por enfermedades contagiosas, no fueran inválidos, dementes o sexagenarios ya que la legislación del momento prohibía el ingreso al país de extranjeros que presentaran algunas de estas características.

La revisión de los equipajes se llevaba a cabo fuera de los buques, en uno de los galpones del complejo edilicio.

- OFICINA DE TRABAJO Nació como una dependencia de la Comisión de Inmigración (1872) y cumplió un rol importante dentro de las actividades del Hotel, en la búsqueda de trabajo, colocación y traslado de los inmigrantes al sitio donde hubieran sido solicitados.

Paulatinamente, la oficina de trabajo extendió sus funciones. Contando hacia 1913 con salas destinadas a la exposición de maquinarias agrícolas y la enseñanza de su uso para los hombres, oficina de intérpretes, de proyecciones, oficina de colocación y de enseñanza de labores domésticas a las mujeres. Asimismo, una oficina dactiloscópica 
se encargaba de confeccionar las cédulas de identidad de los inmigrantes, de acuerdo al "moderno sistema Vucetich". ${ }^{24}$

En la planta baja funcionaba una sucursal del Banco de la Nación Argentina, cuyo propósito era el de facilitar a los inmigrantes las operaciones de cambio. Desde este edificio, se ejercía la dirección y planificación de las políticas migratorias en todo el país, y la administración del Hotel de Inmigrantes.

- HOSPITAL equipado con los elementos más modernos de su época, atendía a los miles de inmigrantes que arribaban a Buenos Aires afectados, sobre todo, por enfermedades vinculadas a las vicisitudes del viaje, la mala alimentación y las penurias.

- HOTEL su estructura estaba conformada por hormigón armado con un sistema de losas, vigas y columnas de ritmo uniforme. Se destacaba por su volumen simétrico, con fachadas de líneas simples y sobria ornamentación que enfatizaban el acceso principal. La construcción era de calidad: contaba con escaleras de mármol de carrara, las paredes estaban pintadas de blanco, y las áreas húmedas poseían mosaicos traídos de Europa, lo que acentuaba en todos los ámbitos la sensación de amplitud y luminosidad.

Distribuido en cuatro (4) niveles. Los primeros tres (3) pisos correspondían a los dormitorios compuestos por espacios amplios dispuestos a ambos lados de un corredor principal con una capacidad total para doscientas cincuenta (250) personas, separadas por sexo y dispuestas en cada uno de sus pisos. En la planta baja se encontraba el gran comedor con capacidad para setecientas (700) personas en cada turno de comida.

Durante la mañana a los inmigrantes los despertaban muy temprano las celadoras, las mujeres se dedicaban a los quehaceres domésticos, como el lavado de la ropa o el cuidado de los niños y los hombres gestionaban su colocación en la oficina de trabajo. Con turnos dispuesto para el almuerzo, a la tarde a los niños se les daba la merienda, después comenzaban los turnos para la cena, y luego quedaban abiertos los dormitorios.

\footnotetext{
24 Sistema mediante el cual se identificaba a las personas por sus huellas dactilares, creado por Juan Vucetich.(1891).
} 
Al llegar al hotel, se les entregaba un número que les servía para entrar y salir libremente, y conocer de a poco la ciudad. El alojamiento por "Reglamento", era gratuito por cinco (5) días, pero generalmente se extendía por caso de enfermedad o de no haber conseguido un empleo. (Ver Fig. № 18 a 22).

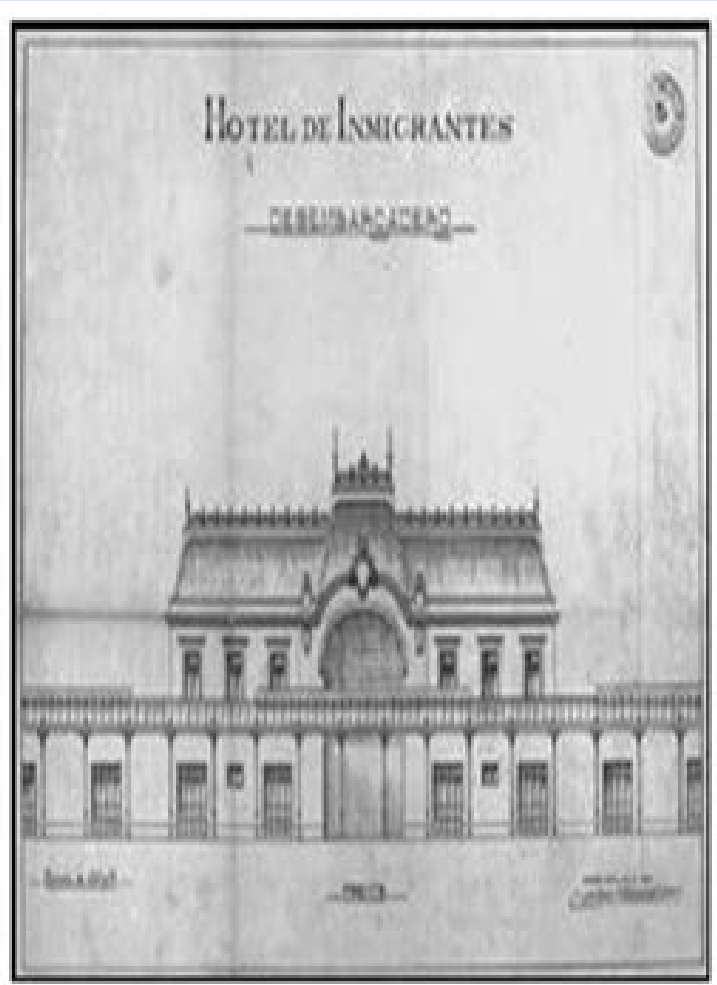

Fig. N 18 y 19.- Imágenes fachada principal y planta del Desembarcadero "Hotel de los Inmigrantes"Buenos Aires, Argentina- 25

\footnotetext{
${ }^{25}$ Autor y fecha de creación desconocidos, Ilustraciones en blanco y negro- Museo Nacional de la Inmigración http://www.migraciones.gov.ar/accesible/indexN.php?hotel - Extraído de internet el 26/04/19

Conjunto Edilicio Ministerio de Agroindustria de la Nación (ex Asilo Nocturno de la Capital)
56 "Desarrollo de los instrumentos para la Conservación e Intervención del Patrimonio
Arquitectónico. Hacia un Plan de Gestión".
} 
FACULTAD DE ARQUITECTURA Y URBANISMO - UNIVERSIDAD NACIONAL DE LA PLATA

MAESTRÍA EN CONSERVACIÓN, RESTAURACIÓN E INTERVENCIÓN DEL PATRIMONIO ARQUITECTÓNICO Y URBANO (CRIP - FAU / UNLP)

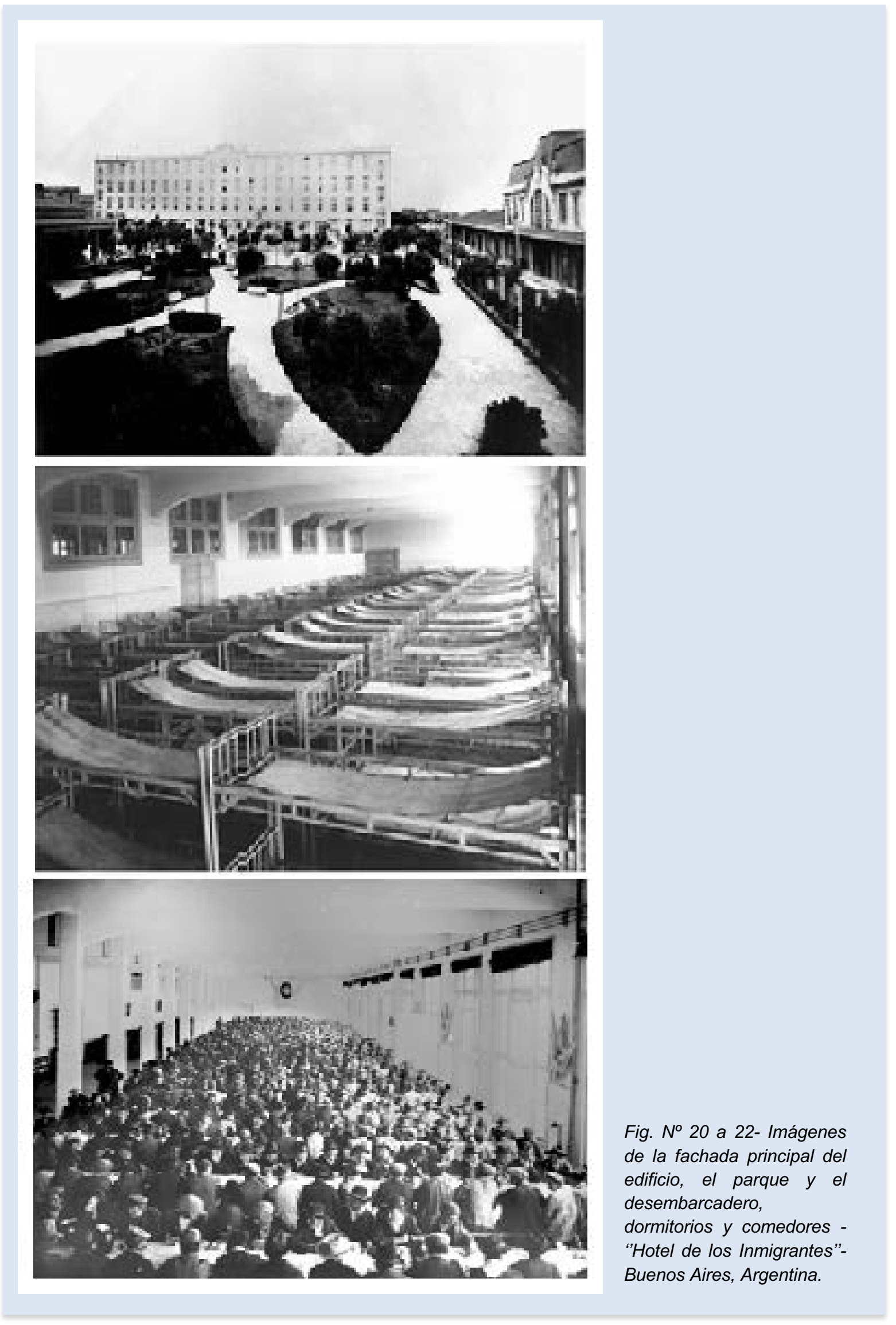




\subsubsection{Conclusiones parciales}

De los sitios descriptos anteriormente el Hotel de los Inmigrantes fue el que albergó la mayor infraestructura edilicia y además el que funcionó más extendidamente en el tiempo, por tal motivo será el contemplado para la siguiente comparación.

Analizando el esquema funcional planteado para el Hotel en relación al proyecto original del asilo nocturno de la capital, podemos establecer algunas pautas comunes a ambos casos.

En ellos se observan:

- Diseño de los espacios: a partir de cómo estaban concebidos los espacios, puede deducirse la intencionalidad de crear ambientes amplios, simples, depurados, en donde primara la practicidad pero que a la vez no invitaran al inmigrante a permanecer en el lugar, sino que lo hicieran sentir que estaba de paso.

- Distribución de los espacios: habitaciones de plantas libres rodeadas de corredores, con diferenciación por pisos según sexo y edad (pabellones para mujeres, niños en plantas inferiores y para hombres en las superiores).

- Espacios educativos: presentes en estos ámbitos mediante clases impartidas siempre bajo la concepción de estadía temporal.

- Vida en comunidad: mediante la implementación de grandes comedores y espacios de uso compartido.

- Control y asistencia: Habitaciones para guardias, celadores y médicos.

- Recepción y estadía acotada: Estos edificios fueron concebidos para alojar a todo inmigrante que arribara al país y cuya permanencia le fuera permitida, proporcionándole estadía gratuita por el plazo máximo de cinco (5) días o en algunos casos esto podía extenderse hasta que el recién llegado consiguiera trabajo. 


\subsection{Desarrollo histórico}

2.2.1. Nuevo destino de la obra. Modificaciones formales, funcionales y de uso de los espacios

Luego que fuera adjudicada la obra, la construcción de los edificios comenzó su paulatino avance con altibajos que hicieron que esta se demorara más de lo inicialmente previsto. Durante este período fue que se desarrolló la Primera Guerra Mundial (19141918). Y si bien no se tienen registros escritos acerca de cómo la guerra afectó la continuidad de los trabajos del asilo es sabido que perjudicó profundamente la economía argentina, provocando la declinación del flujo de capitales, la incorporación de mano de obra especializada proveniente del exterior y el arribo de las manufacturas Europeas.

Tampoco hay documentación feaciente que revele porque durante la ejecución se modificó su destino. Así fue que hacia el año 1917 y antes de ser inaugurado el conjunto, se reformaron parte de los edificios y fueron entregados al Ministerio de Agricultura.

Esto explica la aparición de una cantidad de divisiones y agregado de equipamiento que fue adicionado a los planos originales, los cuales fueron incorporados utilizando materiales de la misma época. Un ejemplo de esto, verificable tambien en otros planos, es el que pertenece a la planta del primer piso de Paseo Colon $N^{\circ} 982$.

En el mismo se puede observar la subdivisión de los amplios pabellones del proyecto original al que se suman tabiques que particionan los espacios y dan lugar a las nuevas oficinas comprendidas por: la Dirección general de Ganadería y las Direcciones generales de Comercio e industrias las cuales ocupan la totalidad de la planta mencionada. (ver Fig. №23).

Es así entonces que, tanto este como otros planos también digitalizados por el CeDIAP nos ayudan a concluir que, con el edificio casi terminado proyectado como asilo nocturno se dividieron las grandes salas del plan original, en oficinas y otras dependencias.

Por su parte los accesos, los pasillos y sectores de circulación vertical mantuvieron su distribución original por lo que no sufrieron modificaciones. 


\section{M.0.P.}

DIRECCION GENERAL DE ARQUITECTURA

EDIFICIO OCUPADO POR EL MINISTERSO DE GGRICULJURG PASEO COLON Y CARLOS CyLVO

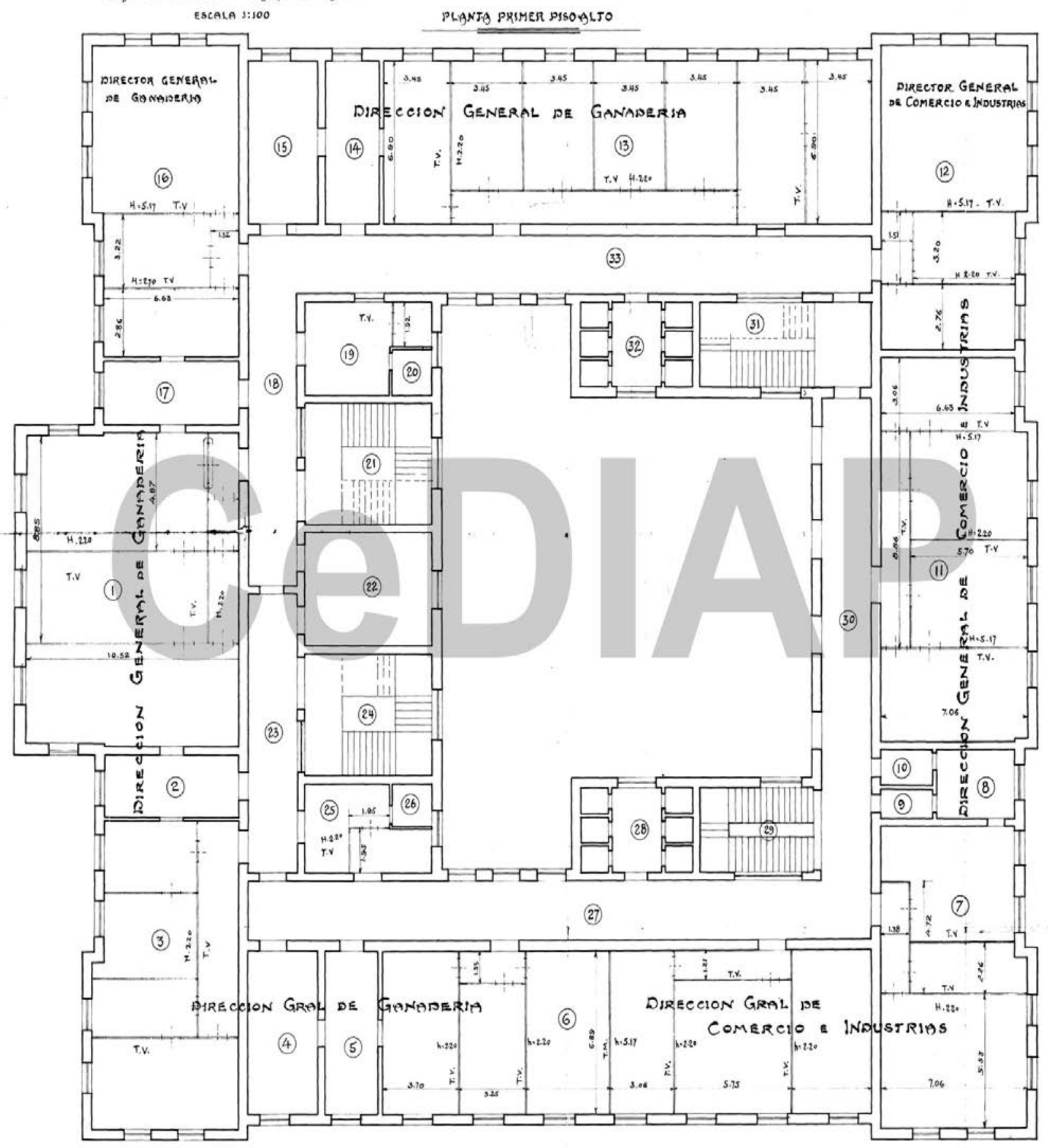

Seccion Conservacion de Euificios Fiscales

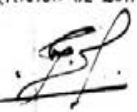

Fig. N 23.- Planta del primer piso Edificio Paseo Colon No 982, año 1917 (Digitalizado por el CeDIAP).

Conjunto Edilicio Ministerio de Agroindustria de la Nación (ex Asilo Nocturno de la Capital) "Desarrollo de los instrumentos para la Conservación e Intervención del Patrimonio Arquitectónico. Hacia un Plan de Gestión”. 
En otro plano de modificaciones fechado en septiembre de 1923, se pueden observar las reformas correspondientes a la cara noreste del primer piso del edificio, entre ellas la terminación de solados y la unión entre los distintos materiales, o el detalle de los umbrales de mármol de las puertas principales de acceso a los despachos. Como así también la diferenciación de los pisos de los pasillos compuestos por mosaicos y en el interior de las oficinas por madera de pinotea machimbrado de 1"x 3 " sobre tirantes de 2"x 3 " cada $0.70 \mathrm{mts}$ con umbrales de mármol blanco de $0.04 \mathrm{mts}$ de espesor. (Ver Fig. $\mathrm{N}^{\circ} 24$ y detalle).

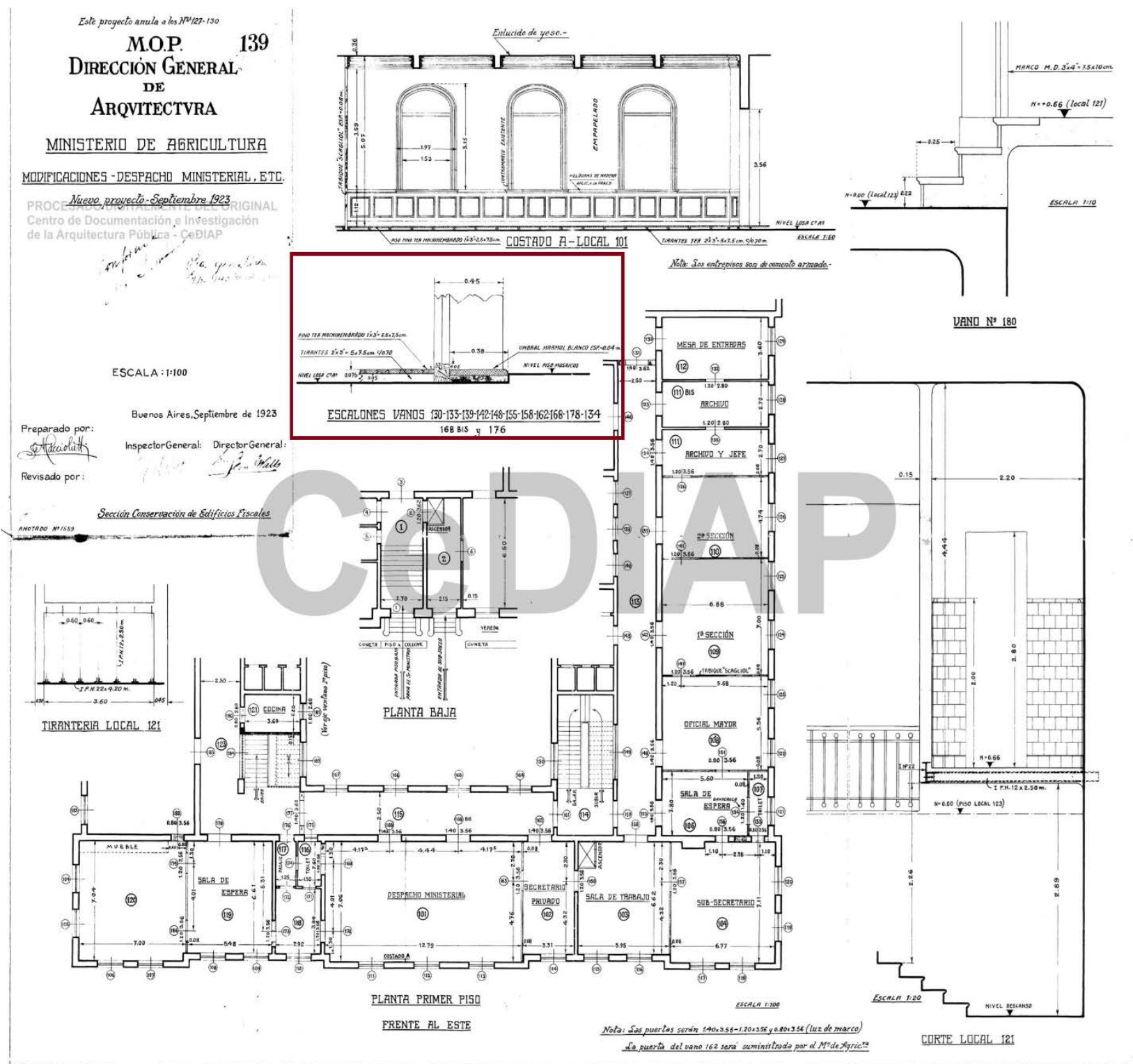

Fig. No 24.- Plano de Modificaciones de despachos en 1er Piso (Digitalizado por el CeDIAP, año 1923). 


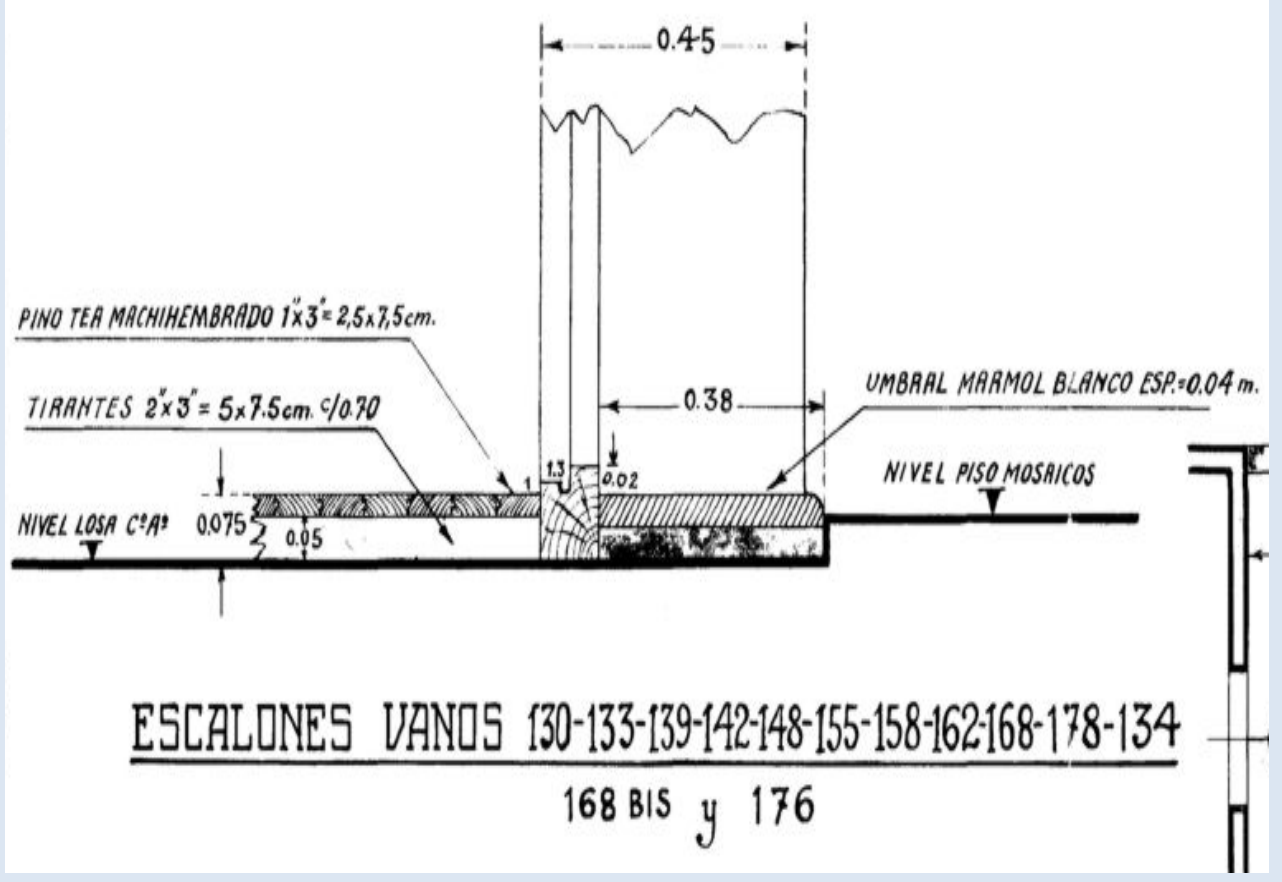

Fig. N²4 (2). - Detalle plano umbrales de mármol.

2.2.2. Transformaciones identificadas a lo largo del tiempo

\section{a) Ampliación y construcción del segundo edificio (Paseo Colón N922)}

A pocos años de haberse inaugurado el entonces Ministerio de Agricultura, se adquiere la otra mitad de la manzana (cara Norte) y así surge la incorporación más importante para el conjunto, con la construcción del segundo edificio principal. Dicha tarea estuvo a cargo de la empresa Kimbaun y Cía. con una obra que demandó tres (3) años, terminándose en 1931.

Originariamente albergó dependencias de YPF (Yacimientos Petroliferos Fiscales), hasta que en 1938 pasó a formar parte de la sede de la Secretaría de Agricultura y Ganadería de la Nación ${ }^{26}$, asumiendo luego y durante varios años el grado de Ministerio.

En el año 1948, se instaló en un sector del nuevo edificio la Dirección de Meteorología Nacional.

${ }^{26}$ Decreto N 102.093 es autorizada, por acuerdo de ministros, la adquisición de Paseo Colón 922, (marzo de 1937). 
A pesar de su aspecto exterior idéntico al primero, varios elementos arquitectónicos, materiales y detalles de los interiores variaron en el diseño.

El primero tiene estructura metálica y enladrillado, con ventanas y puertas de madera, el segundo es de hormigón y exhibe en su patio interno ventanales de metal y un claro aire racionalista.

Ambos poseen plantas cuadrangulares que encierran sendos patios centrales. En torno a ellos se desarrolla un primer anillo donde, entre otros locales, se ubican las escaleras y los servicios sanitarios. Un segundo anillo, básicamente de oficinas, da al exterior. Entre ambos corre un ancho pasillo que circunda todo el perímetro.

La composición utiliza un eje de simetría sobre el acceso central, que divide a cada uno en dos mitades idénticas, siguiendo el esquema de alas laterales y volúmenes esquineros, levemente exentos.

La imágen exterior de los dos edificios es similar, con un basamento donde asoman las ventanas de los locales ubicados en el semisótano. Elevado respecto del nivel de vereda se dispone la planta baja y por encima los pisos 1 ero y 2 do.

El 3er piso, ocupado por dependencias como los dos anteriores, se encuentra rematado por mansardas de pizarra inglesa, con cuerpos salientes en las cuatro esquinas principales que conforman una suerte de torres.

En un 4to nivel, una azotea accesible recorre el perímetro exterior de los edificios con objetos decorativos que originariamente eran de zinc liso ${ }^{27}$ y fueron reemplazados en una anterior intervención por reproducciones en PRFV (plástico reforzado con fibra de vidrio). (Ver Figura $N^{\circ} 25$ y 26).

27 Según consta en el "Proyecto de Asilo Nacional Nocturno para la Capital Federal", del Ministerio de Obras Públicas, Direccion General de Arquitectura Buenos Aires, 1912 


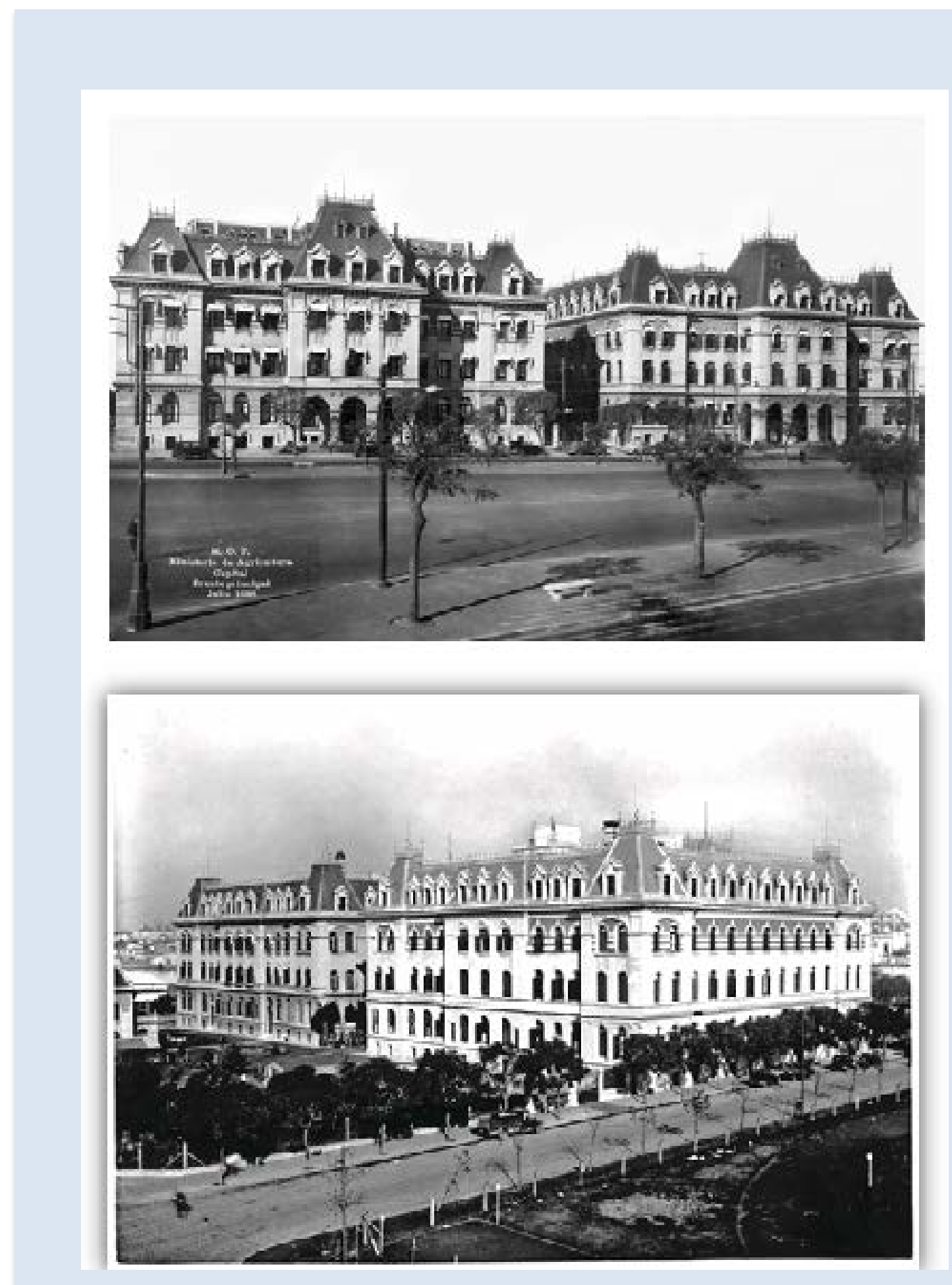

Fig. N N 25 y 26.- Fotografía frontal del conjunto edilicio desde la actual Avenida Paseo Colón y Vista desde calle Estados Unidos, esquina Azopardo. circa 1938 (Digitalizadas por el CeDIAP). "Desarrollo de los instrumentos para la Conservación e Intervención del Patrimonio Arquitectónico. Hacia un Plan de Gestión". 
Centrando la mirada del conjunto hacia su entorno más próximo, en esta última fotografía se puede apreciar su gran monumentalidad. No solo comparando las dimensiones de los volúmenes en relación con las alturas que prevalecían en la ciudad de Buenos Aires de esa época, sino también en las características propias de la construcción y la envergadura que estos adquieren frente al resto de las edificaciones.

En lo que refiere al conjunto hacia su interior, muy tempranamente los dos edificios auxiliares destinados a cocheras y lavaderos ubicados en la parte sudeste de la manzana fueron unificados. Construyendo un volúmen que los aunó y respetó el estilo de los preexistentes. (Ver Figura $N^{\circ} 27$ ).

Fig. $N^{\circ}$ 27.- Plano general del conjunto edilicio a color (Digitalizada por el CeDIAPautor desconocido).

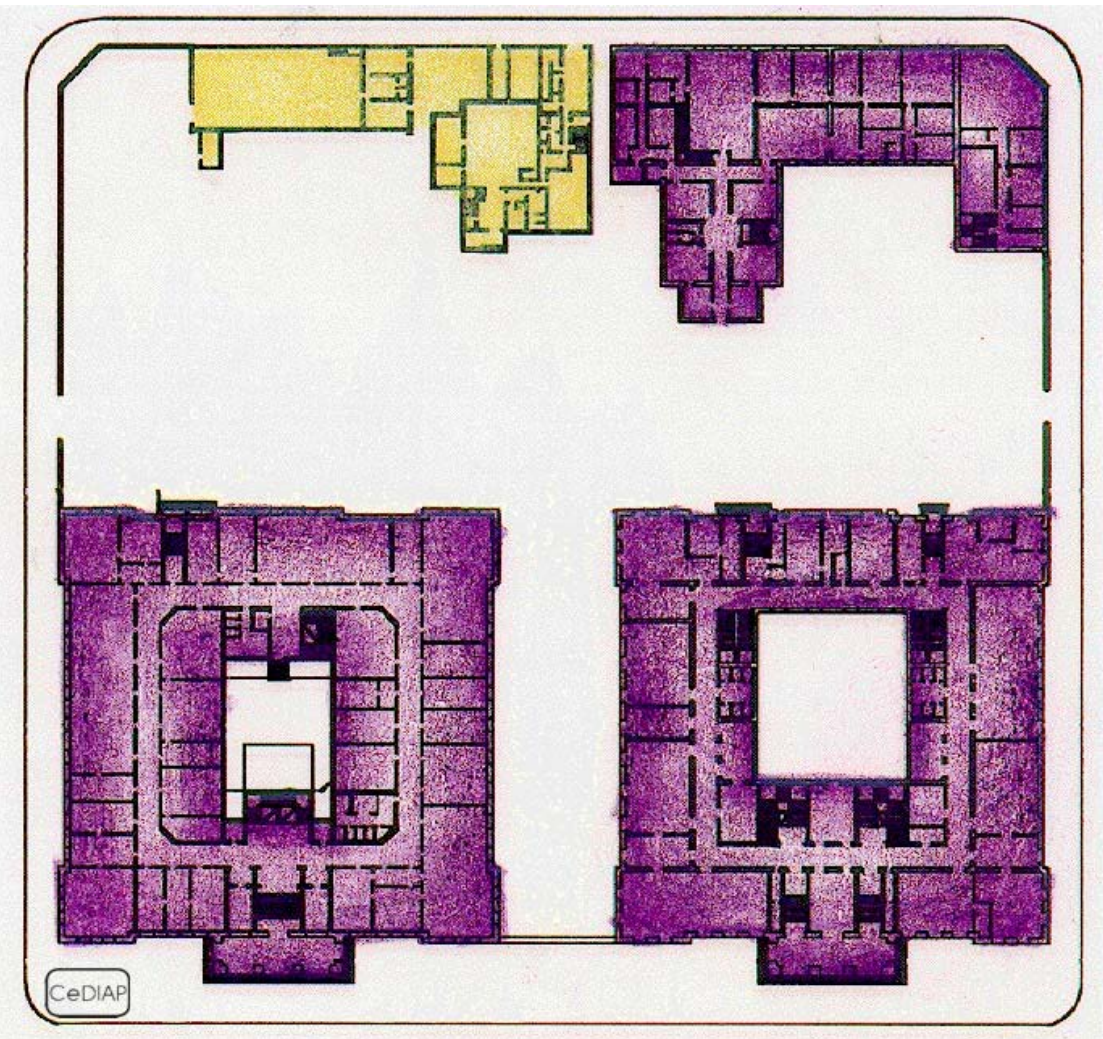

En el plano se pueden observar los dos edificios principales sobre la calle Paseo Colón, los anexos sobre la fachada sud-este ya unificados y un cuarto volumen (representado en color amarillo) conformado por la biblioteca que años más tarde fue demolido y luego reconstruido en un estilo moderno que diferencia su temporalidad respecto al resto. 


\section{b) Proyecto de construcción de Pasaje subterráneo}

En planos del año 1928 digitalizados por el CeDIAP, correspondientes a la planta del subsuelo de Paseo Colon N922 que inicialmente pertenecía a Yacimientos Petrolíferos fiscales (YPF), puede observarse una escalera ubicada sobre el sector central de la fachada Sur. La misma vinculaba al subsuelo con la planta baja del espacio entre edificios. (Ver Fig. $\left.N^{\circ} 28\right)$.

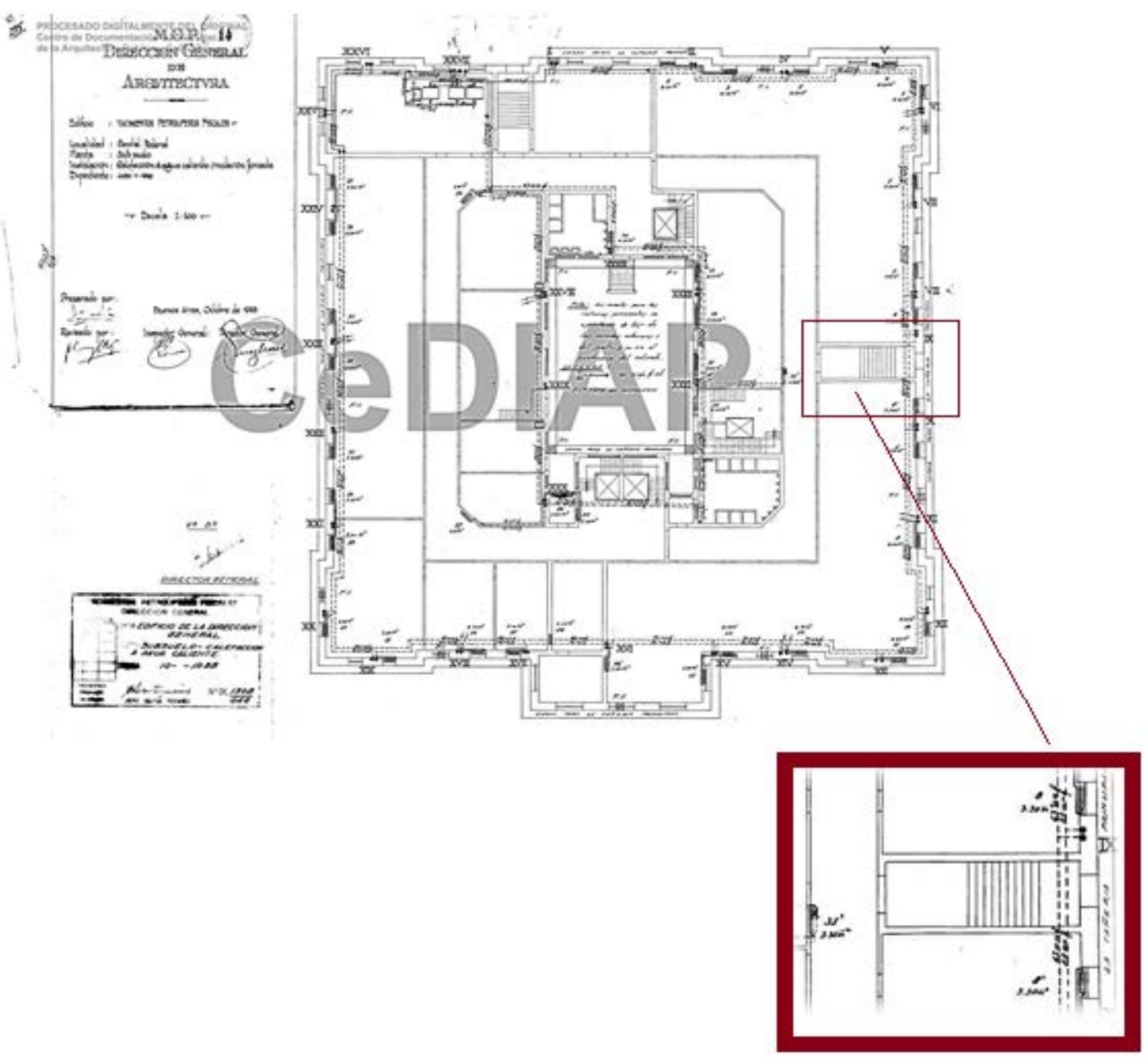

Fig. $N^{\circ}$ 28.- Subsuelo Paseo Colon N922 (Plano digitalizado por el CeDIAP). 
Si bien en la actualidad esa escalera es inexistente, realizando un relevamiento in situ puede observarse lo siguiente:

El sector en cuestión está ocupado por la oficina $\mathrm{N}^{\circ} 55$ perteneciente al pañol del área de mantenimiento del actual Ministerio.

El ingreso al mismo se da por medio de una puerta doble, mientras que el resto de las puertas de esa ala son de una sola hoja. Esta diferenciación no posee a simple vista ninguna justificación ya que la superficie de la oficina es reducida. Interiormente se aprecia un cambio en la terminación de las paredes laterales que no son lisas como las demás, sino que poseen buñas y se deduce conformarían la transición entre el espacio interior y el exterior. Por otro lado, el marco de la carpintería de esa oficina está cortado y por debajo de él se observa un gran parche de revoque. Lo que lleva a pensar que allí se encontraban originariamente la escalera y seguidamente a ésta la puerta que, en algún momento fueron retiradas, incorporando una ventana más pequeña y cubriendo el vano con mampostería hasta completar la altura faltante. (Ver Fig. $\mathrm{N}^{\circ} 29$ a 31).
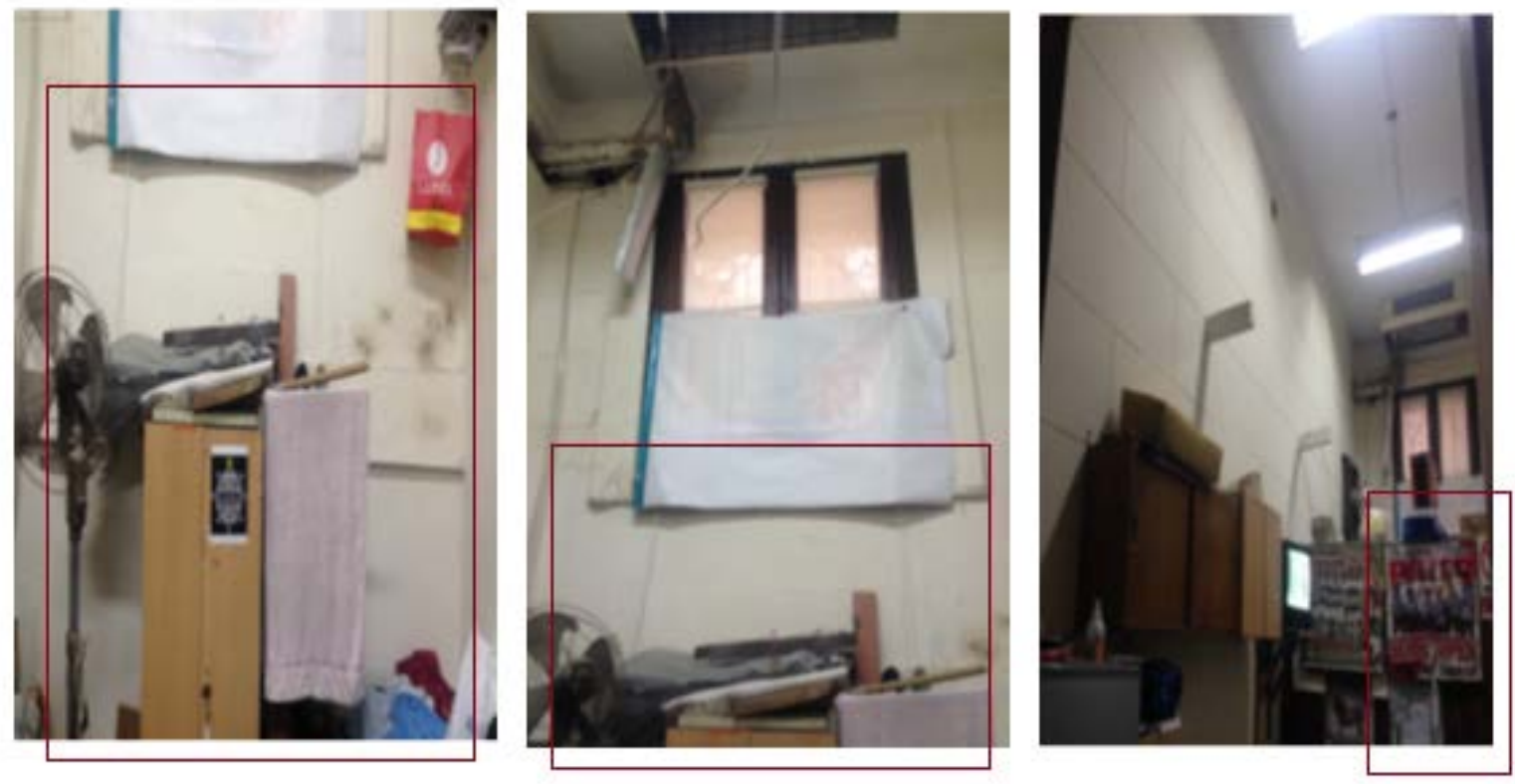

Fig. N²9 a 31.- Imágenes actuales Pañol oficina N 55 edificio Paseo Colón 922 Subsuelo (Autoría Propia).

En relación con el mismo sector, planos que datan del año 1947 (también digitalizados por el CeDIAP) muestran el detalle del proyecto de un pasaje subterráneo de comunicación entre edificios y su correspondiente planilla de locales. (Ver Fig. №32 y 
33). Mientras que la planta baja, según puede apreciarse en fotos de la época fue equipada con canteros y posteriormente ocupada por un área de estacionamiento hasta la actualidad.

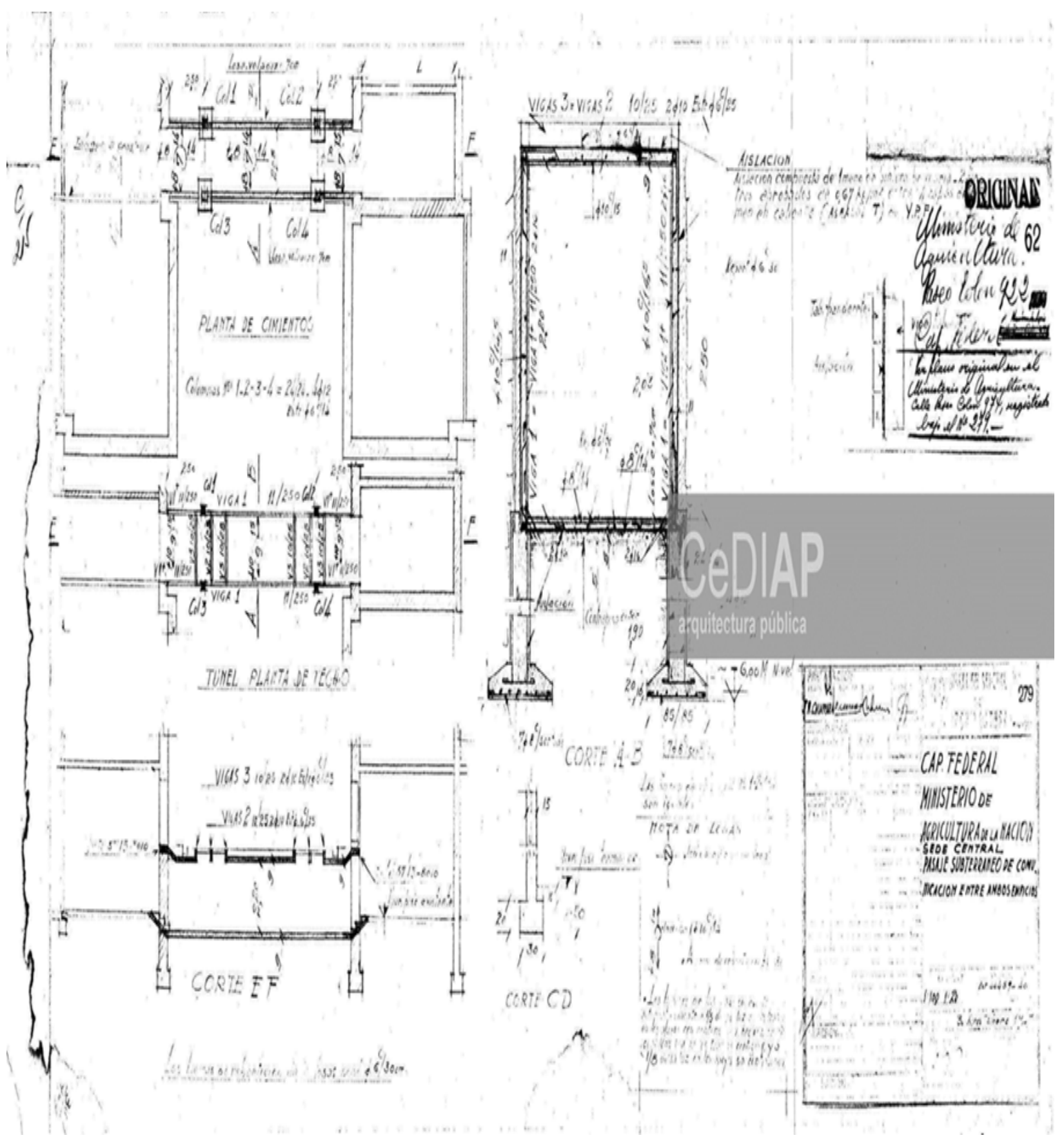

Fig. $N^{\circ}$ 32.- Plano de planta, cortes, vistas del proyecto original del Pasaje subterráneo entre edificios. (Año 1947, digitalizado por el CeDIAP). "Desarrollo de los instrumentos para la Conservación e Intervención del Patrimonio Arquitectónico. Hacia un Plan de Gestión". 


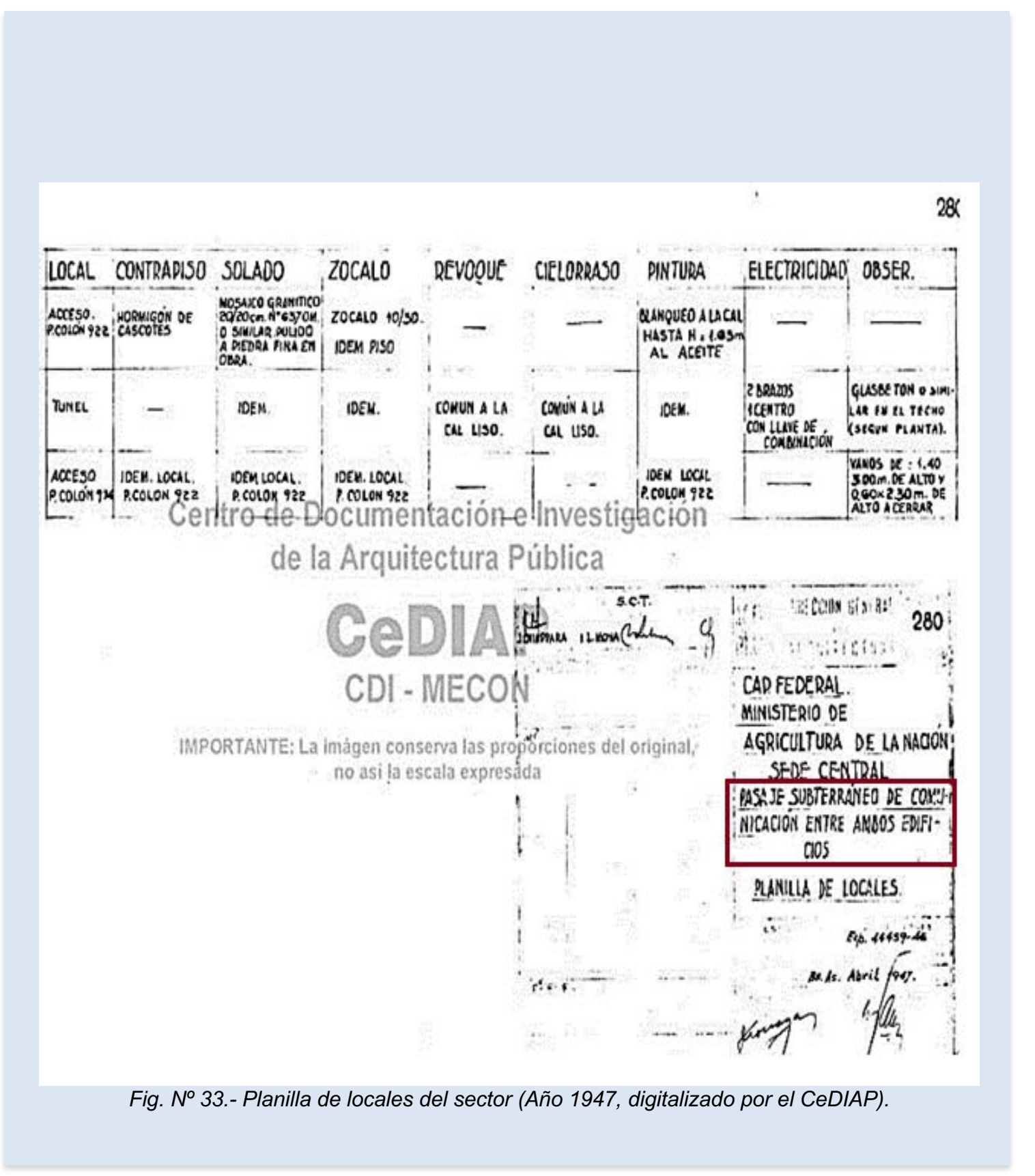

Volviendo al pasaje subterráneo y más allá del hallazgo de esta documentación no se tienen mayores registros a la fecha de su efectiva construcción, recomendándose la realización de cateos para continuar con esta investigación. 


\section{c) Parquización y espacios de estacionamiento.}

La siguiente fotografía fue tomada hacia el año 1938 aproximadamente. En ella se puede observar el detalle del contrafrente de uno de los edificios hacia la actual calle Estados Unidos y como se erigía en un entorno despoblado rodeado de arbolada.

El área que muestra la fotografía permite ver una zona parquizada con canteros delimitando el espacio de circulación vehicular. (Ver Fig. № 34).

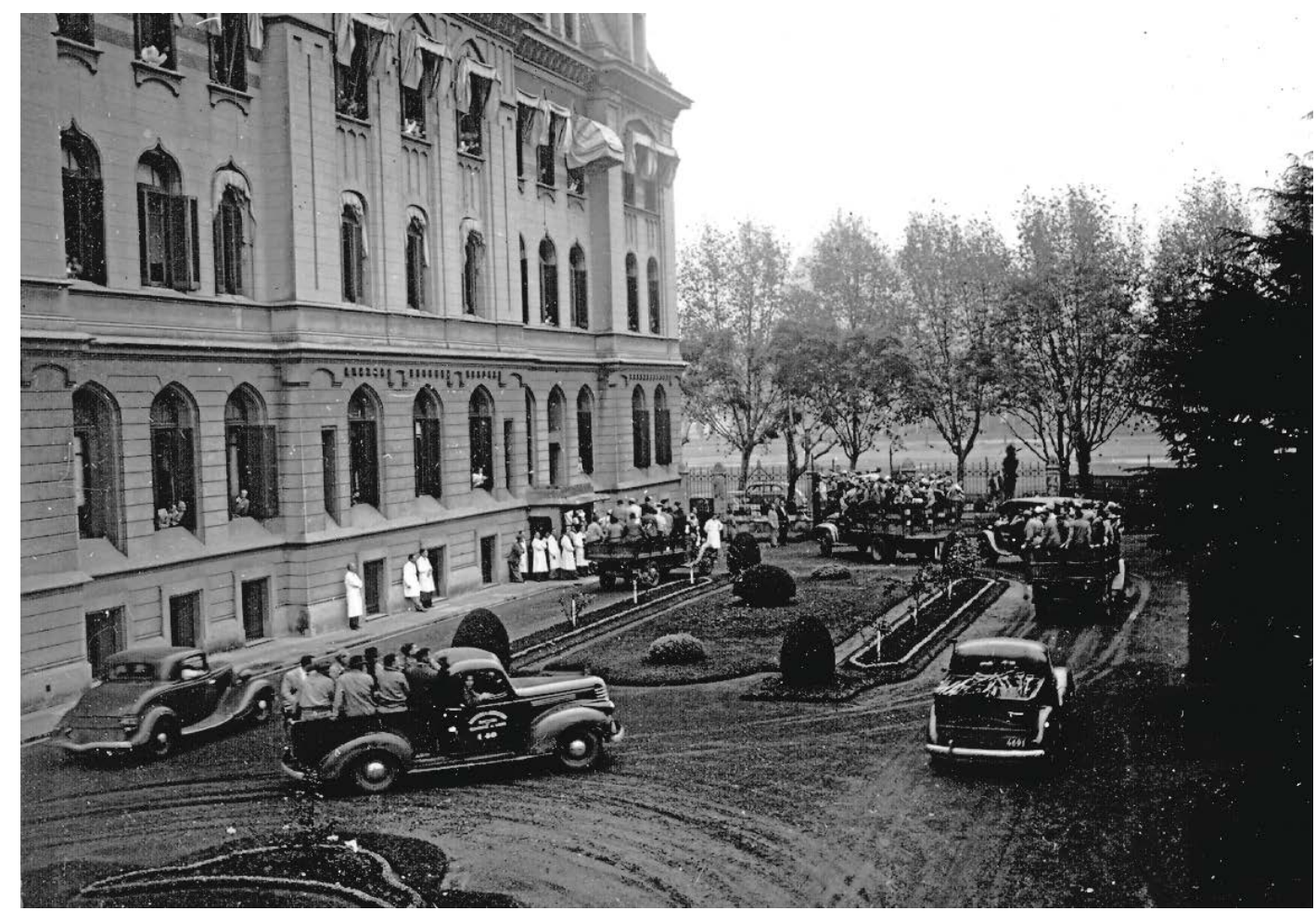

Fig. N 34.- Fachada trasera del Edificio Paseo Colón N 922, circa 1938. Fotografía Blanco y negro, digitalizada por el CeDIAP.

En cada uno de los edificios que integran el conjunto han habido a lo largo de los años modificaciones respecto al proyecto original, como adiciones de volúmenes y subdivisión de oficinas.

Una muestra de ello se puede observar en el 4to Piso de Paseo Colón $N^{\circ}$ 982. Allí nos encontramos actualmente frente a una realidad particularmente compleja.

\footnotetext{
\begin{tabular}{l|l} 
Conjunto Edilicio Ministerio de Agroindustria de la Nación (ex Asilo Nocturno de la Capital) \\
"Desarrollo de los instrumentos para la Conservación e Intervención del Patrimonio \\
Arquitectónico. Hacia un Plan de Gestión".
\end{tabular}
} 
La planta originalmente estaba constituída por una terraza accesible a la cual se ingresaba por medio de una escalera caracol ubicada sobre su cara oeste, dentro de la torreta principal, según se observa en distintos cortes de los edificios.(Ver Fig.Nㅜ5).

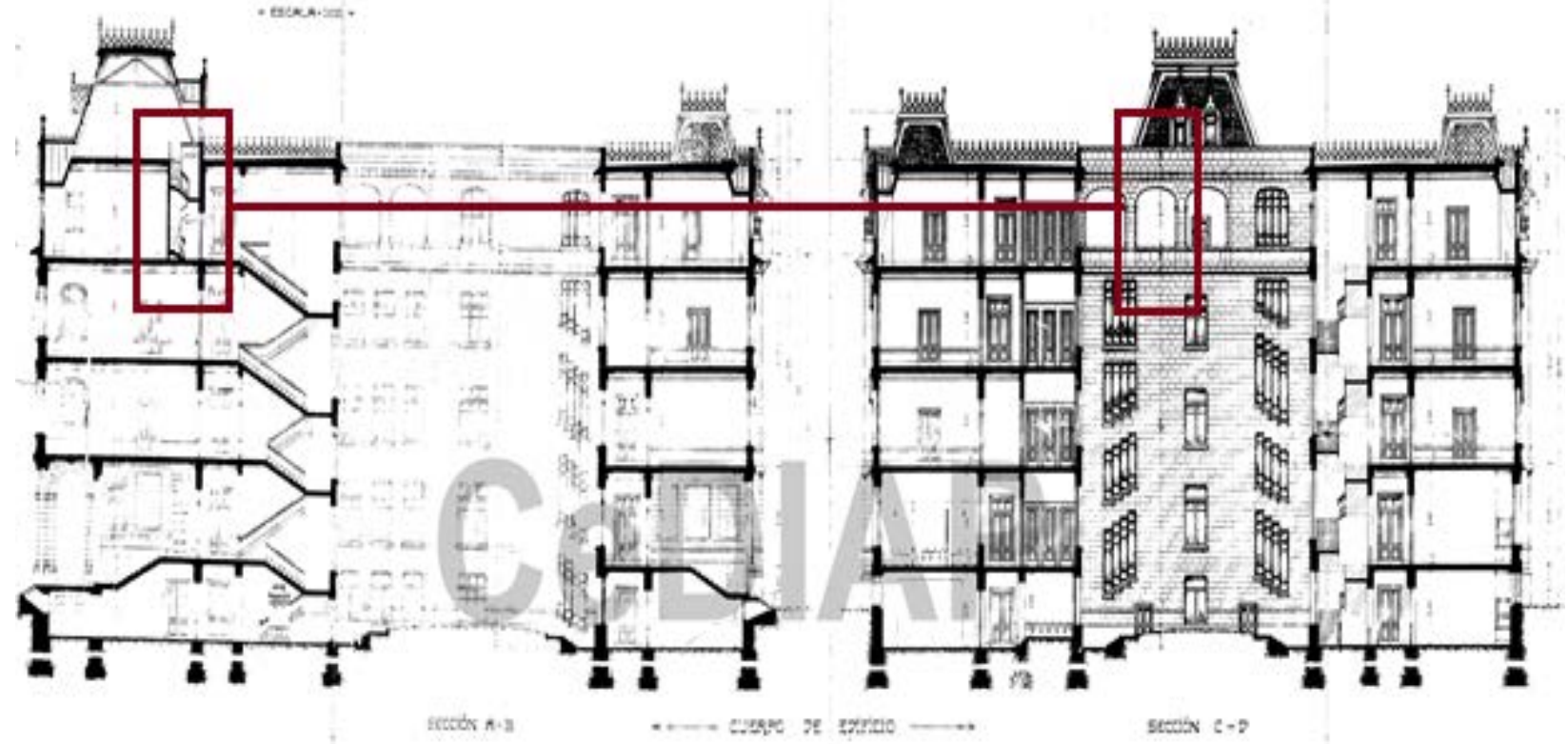

Fig. N'35.- Plano de corte transversal del edificio Paseo Colón $N^{\circ} 982$ y detalle de sector escalera. (Digitalizado por el CeDIAP).

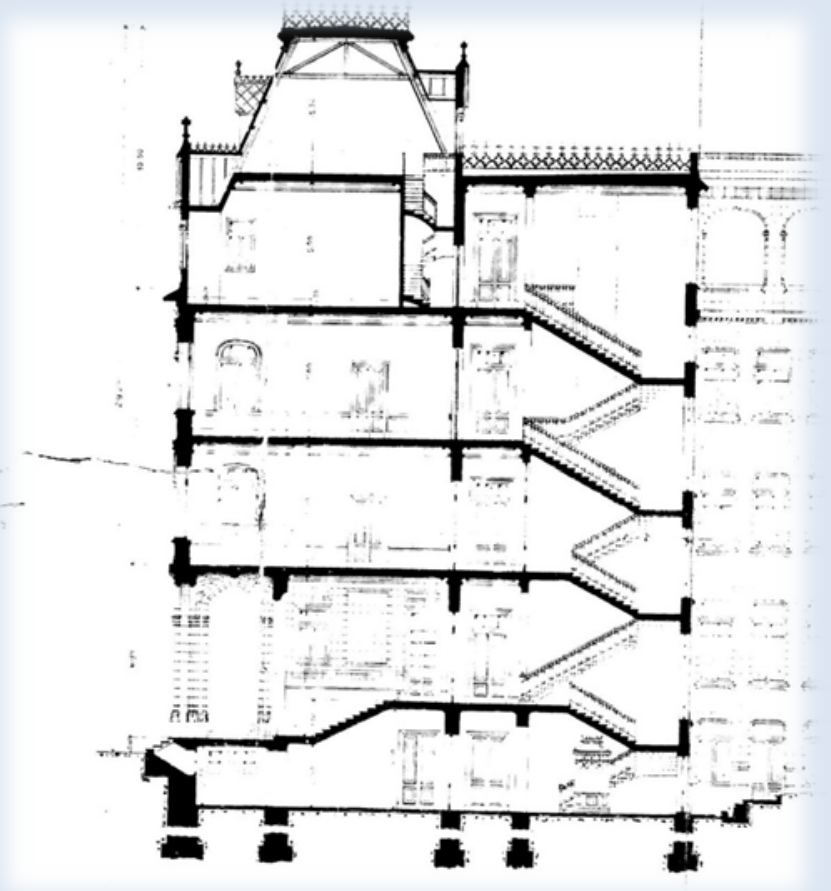


En intervenciones posteriores se fueron adicionando locales destinados a consultorios médicos, sanitarios y un ascensor pequeño con capacidad para hasta tres (3) personas. Dicha ampliación aparece en planos que datan de 1936 e imágenes de la época (ver Fig. $N^{\circ} 36$ y 37$)$.

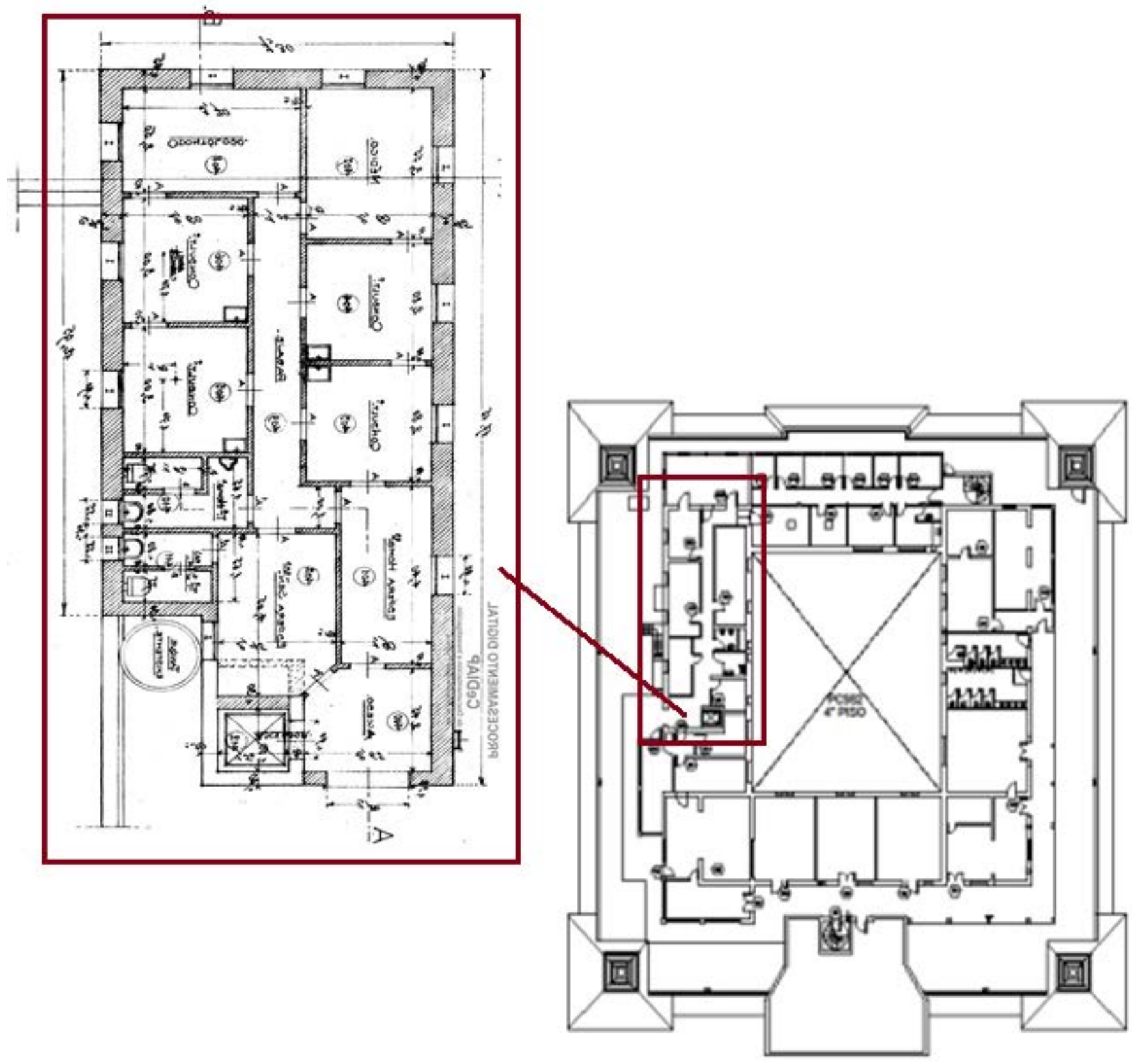

Fig. No 36 y 37.- Foto Antigua Ampliación sector NE del 4to piso del edificio de Paseo Colon N 982 (Circa 1936, digitalizado por el CeDIAP) y Foto actual del mismo sector (Autoría Propia).

Conjunto Edilicio Ministerio de Agroindustria de la Nación (ex Asilo Nocturno de la Capital)
"Desarrollo de los instrumentos para la Conservación e Intervención del Patrimonio
Arquitectónico. Hacia un Plan de Gestión". 
Otras adiciones como espacios de oficinas, parrillas y escaleras se fueron incorporando paulatinamente,eliminando los antiguos consultorios, hasta ocupar actualmente la totalidad de la planta, dejando libre unicamente un área de circulación perimetral. (ver Fig. No 38 y 39$)$.

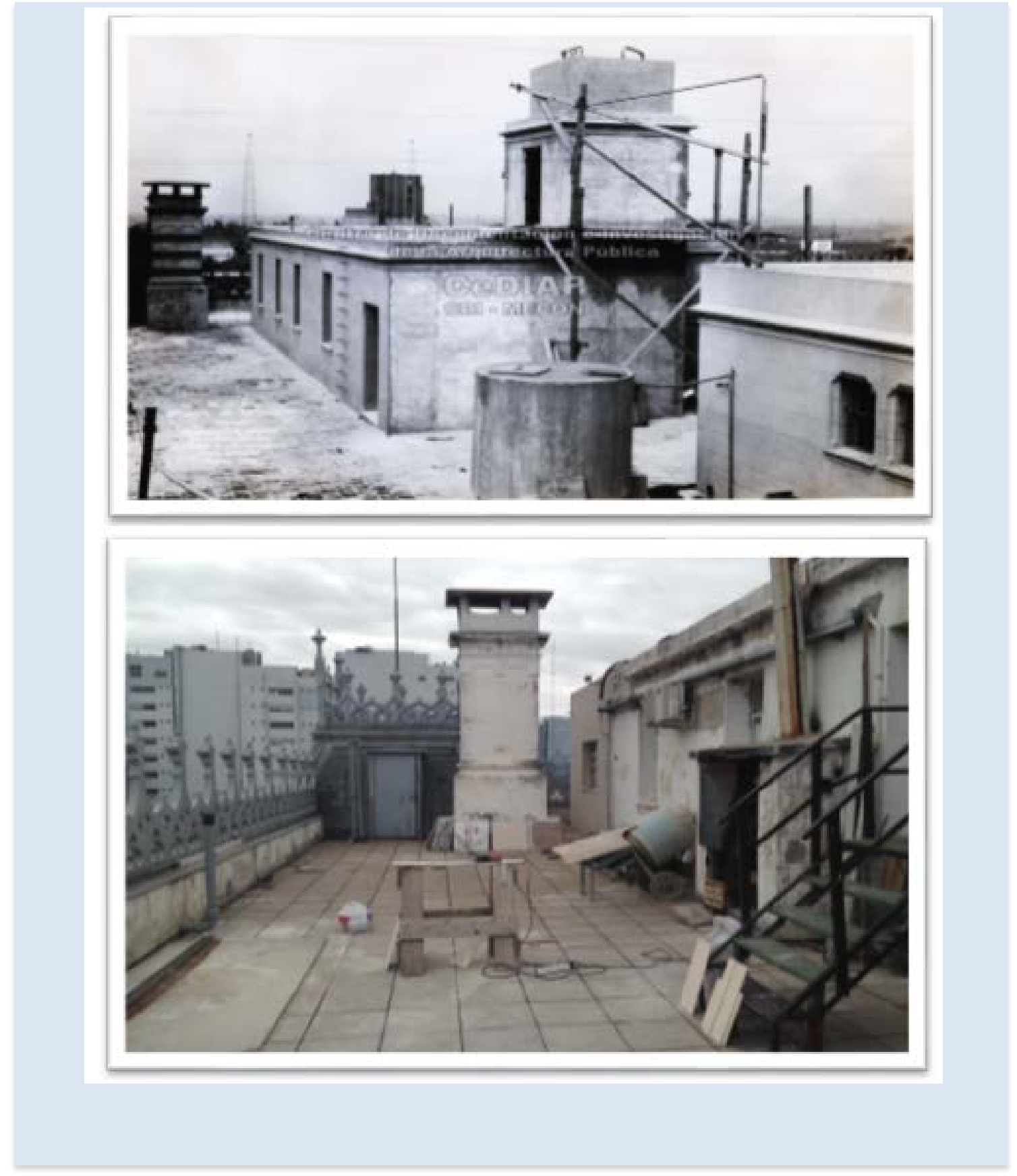

Fig. No 38. Imágen general del 4to piso del edificio Paseo Colón 982 con sector destinado a consultorios medicos. (Fotografia Blanco y negro, Digitalizada por el CeDIAP), año 1936.

Fig. № 39. - Imágen actual sucesivas del 4to piso del edificio Paseo Colón 982 (Fotografía a color de autoría propia). 
Otros espacios también han sufrido modificaciones, entre los que se destacan: sanitarios que fueron demolidos y hoy están destinados a áreas de trabajo, sectores sin edificar que actualmente constituyen oficinas, sumado a nuevas funciones que se fueron incorporando y antes eran inexistentes como por ejemplo baños para discapacitados, escaleras exteriores de escape, etc.

\subsubsection{Conclusiones parciales}

Podria decirse que las transformaciones que sufrio el conjunto a lo largo del tiempo, tuvieron que ver principalmente con la adquisición de la otra mitad de la manzana, lo que permitió sumar mayor superficie y pensar asi en construir un edificio gemelo al principal ampliando considerablemente las areas de trabajo. Por otro lado el incremento de la cantidad de personal del entonces Ministerio de Agricultura, hicieron necesario generar nuevos espacios de oficina o subdividir los ya existentes.

A su vez la incorporación de los vehiculos en las tareas diarias, promovió la creación de áreas de estacionamiento interno y espacios verdes, generando sectores de expansión en el pulmón del conjunto. También fueron adosados nuevos volúmenes a las terrazas y los jardines internos de cada uno de los edificios principales. Los que permitían en algunos casos una lectura integrada de los espacios prexistentes mientras que en otros referian a elementos adicionados sin criterio alguno, generando un fuerte contraste con su entorno inmediato.

Es así que, parte de estas adiciones influyeron positivamente en el conjunto pero otras provocaron la ruptura de la lectura general y consolidada que el bien había logrado hasta entonces.

\subsection{Marco socio-político-cultural de las transformaciones y adecuaciones}

Si bien el conjunto edilicio atravesó sucesivas instancias de adecuaciones a lo largo de los cien (100) años que transcurrieron desde su construcción, se contemplarán cuatro (4) instancias que fueron hito en sus transformaciones.

a) Año 1919 durante la presidencia de Hipólito Yrigoyen se terminó de construir el edificio principal con sus anexos y se tomó la decisión del cambio de destino respecto al proyecto inicial, sin registros escritos de la causa. 
De todas maneras y como ya fue mencionado, se estima que la misma se debió a cuestiones socio - políticas referidas al momento que vivía el país por ese entonces, luego de atravesar una fuerte depresión económica como efecto de la primera posguerra con una alta inflación, la caída del salario real y el aumento del costo de vida. Recién a partir del año mencionado, la economía se reactiva debido a una ola de agitación sindical que abarcó principalmente los sectores vinculados a la exportación y los frigoríficos, entre otros.

Además de todo lo mencionado, el Hotel de los Inmigrantes se encontraba funcionando activamente, la inmigración comenzaba su período de declive. En medio de esa nueva realidad nacional era lógico pensar en destinar el flamante edificio a un nuevo uso, Ministerio de Agricultura.

b) Años 1931 a 1936 En 1931 y luego de tres (3) años, finalizó la construcción del segundo edificio principal del conjunto albergando dependencias de YPF (Yacimientos Petrolíferos Fiscales) hasta que en 1938 pasó a integrar la Secretaría de Agricultura y Ganadería de la Nación.

En ese mismo período se realizaron distintas adecuaciones y modificaciones, las cuales quedaron plasmadas en fotografías y planos de la época. Estas se debieron principalmente a la necesidad de ampliar y redistribuir oficinas en función del incremento de personal y de las nuevas áreas incorporadas.

Según fue mencionado en el capítulo I, hacia el año 1931 se llevó a cabo el Congreso de Arquitectura internacional del cual surgió el manifiesto de la Carta de Atenas, en el que se asentarían las bases de las funciones básicas de las nuevas ciudades.

Por esos años el país se encontraba dentro de la llamada Década infame (19301943) y atravesaba el primer golpe de estado de la historia institucional argentina con el derrocamiento del presidente Hipólito Yrigoyen, quien no supo sortear la crisis económica mundial del 29'. El nuevo presidente, el gral. José Félix Uriburu tampoco encuentra salida a la depresión, hasta que, en el año 1933, durante la presidencia de Justo se tomaron las medidas necesarias para paliar la situación. En tanto la economía continuaba supeditada a las exportaciones agrícolas, principalmente la venta de carne al Reino Unido. El pacto Roca-Runciman profundizó esa dependencia y generó un importante debate en torno a la actividad de los grandes frigoríficos británicos que se vieron beneficiados con el tratado. 
c) Año 1982 Es cuando el conjunto queda regido bajo el Decreto 1063/82 28 que establece que los edificios de más de 50 años de antigüedad, propiedad del estado nacional, están tutelados por la Comisión Nacional de Monumentos, de Lugares y de Bienes Históricos.

El país se encontraba gobernado por el militar Leopoldo Galtieri y estaba atravesado por la Guerra de las Islas Malvinas. Fue una etapa caracterizada por la incorporación de sectores a los volúmenes existentes, los cuales no seguían ningún principio estético y la realización de tareas de mantenimiento de espacios interiores, de los cuales no se han conservado registros escritos y ni planos.

Cabe mencionar que si bien ya se contaba con el existencia de la Carta de Venecia ${ }^{29}(1964)$, como antecedente fundamental para la conservación y restauración de edificios históricos, se hace evidente que estos principios no fueron tenidos en cuenta durante este período.

d) Años 2010 a 2014 Por decisión del entonces ministro Julián Domínguez, se lleva a cabo la licitación que diera inicio a la puesta en valor del conjunto (2010).

El proceso de intervención se desarrolló en los edificios principales a partir de obras simultáneas contratadas por separado atendiendo a la especificidad de cada uno de ellos y se trataron luego los anexos ubicados en la parte posterior del jardín central.

El encargo surgió por iniciativa de las autoridades de la entonces Secretaría de Agricultura Ganadería y Pesca, demandando más de cuatro (4) años de trabajo y contó con el asesoramiento del Arquitecto Marcelo Magadan, Máster en Restauración de Monumentos y Especialista en Gestión de Conservación.

El detalle de los trabajos realizados se desarrollará en el capítulo siguiente en donde se describirá cual fue el proceso de restauración y readecuación edilicia ejecutado. (Ver Capítulo III).

\footnotetext{
${ }^{28}$ Decreto 1063/82 (de la Ley predecesora 12.668 y su modificatoria 27.103) Art. 1: Los funcionarios públicos a quienes corresponda la decisión acerca del destino de los inmuebles de propiedad del Estado cualquiera sea su naturaleza jurídica, de una antigüedad de más de cincuenta (50) años, no podrán autorizar modificación alguna de dichos inmuebles, ni su enajenación, sin la consulta previa de la Comisión Nacional de Museos y de Monumentos y Lugares Históricos, dependiente de la Secretaría de Cultura de la Presidencia de la Nación, las que se expedirán dentro de los sesenta (60) días de la recepción de las actuaciones respectivas, acerca de la conveniencia o no de las medidas que se intentan, teniendo en cuenta respectivamente el valor histórico, artístico o arquitectónico de los inmuebles.

${ }_{29}$ Carta de Venecia (Carta Internacional para la Conservación y la Restauración de Monumentos y sitios - II Congreso Internacional de Arquitectos y Técnicos de Monumentos Históricos) Venecia ,Italia (Mayo de 1964). 


\subsubsection{Conclusiones parciales}

El conjunto edilicio fue atravesando distintas modificaciones y adiciones a lo largo de su historia. Principalmente debido al crecimiento ocurrido tanto con la incorporación de la otra mitad de la manzana, que permitió adicionar un volúmen idéntico al del proyecto original, como así también otros que servirían de apoyo a este.

Asimismo, las funciones e incumbencias del Ministerio también se fueron modificando. Sin embargo, y a pesar de todos estos cambios la lectura de los edificios principales a nivel de fachadas y en relación directa con el resto de la ciudad no fue alterada.

\subsection{Conclusiones}

El mapa socio-habitacional de Buenos Aires en el que surgió el proyecto se fue trasformando producto de distintos factores que intervinieron en ello. Por un lado, como ya fue analizado anteriormente, debido a los cambios que ocasionó la llegada al país de inmigrantes de distintas partes del mundo. Este fue el punto de partida y comienzo de la historia del conjunto en cuestión. Teniendo como función principal la de dar albergue a los recién llegados bajo la premisa de ser un espacio de recepción, alojamiento temporal y rápida ubicación de los extranjeros en sus nuevos hogares.

Los planos originales del conjunto, emergen así como una entidad arquitectónica que forma parte de las tendencias predominantes de la época, siendo un eslabón más dentro del contexto político y social, en constante evolución.

Del análisis morfológico del conjunto se concluye que a través de los juegos de llenos sobre vacíos presentes en movimientos articulados, se rompe la monocromía que caracteriza a casi toda la extensión de las envolventes haciendo que estas no aparezcan como cuerpos planos, sino plásticamente ensamblados. Por otra parte, los accesos con sus escalinatas y las superficies semicubiertas logran generar una aproximación a escala peatonal, reduciendo el impacto que produce la monumentalidad de los edificios. 
A su vez las formas de estas edificaciones se implantan como estructuras cerradas en sí mismas y generan una apertura hacia el interior de sus propios núcleos que resulta invisible desde el exterior.

Por lo expresado la obra se convierte en una pieza urbana de gran escala, pero siendo a la vez absolutamente austera, con predominio del materiales estéticamente afines lo que le permite vincularse a su entorno próximo sin mayores sobresaltos.

En cuanto al desarrollo histórico de su construcción, si bien al momento de su inauguración el destino fue cambiado, rápidamente pudieron realizarse las adaptaciones correspondientes a su nuevo uso. Las transformaciones identificadas a lo largo del tiempo fueron múltiples y en muchos casos no se tiene información acerca de su datación o proceso de ejecución. Dichas innovaciones estuvieron ligadas a múltiples situaciones, ya que los cambios políticos, sociales y/o culturales que afectaron al país a lo largo de sus cien (100) años de vida, no fueron ajenos al conjunto edilicio, sino que repercutieron inevitablemente sobre el mismo.

A su vez los golpes militares impactaron como épocas de visible falta de mantenimiento y ausencia de contratación de profesionales que pudieran aportar una mirada técnica a la arquitectura del lugar.

Por ello varios de los espacios interiores fueron pintados de colores oscuros sin seguir ningún criterio estético que respondiera a la historia del bien, tal como fueron detectados en los cateos realizados durante proceso de intervención del conjunto que se inició hacia el 2010 y se extendió por los siguientes cuatro (4) años. (Esto será detallado en el capítulo III).

Actualmente el conjunto posee una catalogación de protección estructural. Además, posee una declaratoria de APH (Área de protección Histórica). Esto es para aquellos edificios de carácter singular y tipológico que, por su valor arquitectónico, urbanístico o simbólico, caracterizan su entorno, califican un espacio urbano o son testimonio de la memoria de la comunidad.

Esta catalogación junto con las tareas de puesta en valor y readecuación edilicia realizadas, son las que permiten tener hoy un conjunto revitalizado en buenas condiciones de conservación acorde a su uso y función. 


\section{Capítulo III.- PROCESO DE RESTAURACIÓN Y READECUACIÓN EDILICIA}

Preguntas claves:

¿Cómo fue el proceso de intervención del conjunto edilicio?

¿Cuáles fueron los logros obtenidos y cuáles son los aspectos que aún quedan pendientes por resolver?

3.1. Intervención edilicia del conjunto (Años 2010 - 2014)

\subsubsection{Descripción general}

3.1.2. Niveles de Intervención del Inmueble

3.1.3. Etapas de Intervención

3.1.4. Resultados de los trabajos realizados

3.1.5. Conclusiones parciales

3.2. Aspectos no contemplados en la intervención y situación actual

3.2.1. Patologías y deficiencias varias

3.2.2. Conclusiones parciales

\subsection{Conclusiones}




\subsection{Intervención edilicia del conjunto (Años 2010 - 2014)}

\subsubsection{Descripción general}

Contexto político: El conjunto edilicio hasta el año 2008, se constituía como una secretaría que dependía del Ministerio de Economía y, desde aquel año hasta 2009, quedó bajo la cartera de Producción. A partir del 01 de Octubre del año 2009, el departamento fue elevado por la ex Presidenta Cristina Fernández de Kirchner a rango de Ministerio con el nombre de "Ministerio de Agricultura, Ganadería, Pesca y Alimentación" (MAGyP) siendo su primer titular Julián Domínguez, quien sucedió al hasta ese momento secretario de agricultura Carlos Chepp.

Es allí cuando, por decisión del mismo ministro Julián Domínguez a mediados del año 2010, encarga volcar en un pliego la necesidad de que se efectúen diferentes trabajos de mantenimiento y adecuación edilicia, incluyendo la modernización de instalaciones, debido a la magnitud de los deterioros que el complejo había adquirido con el paso del tiempo.

Características del Proceso de Intervención: El mismo se desarrolló durante más de cuatro (4) años y fue materializado por medio de distintos pliegos de licitación. El primero abordó la Restauración de las fachadas exteriores de Av. Paseo Colón 982 y 922 como así también sus patios interiores. Los edificios principales fueron intervenidos a partir de obras simultáneas contratadas por separado atendiendo a la especificidad de cada uno de ellos. Luego se trataron los anexos de menor tamaño ubicados en la parte posterior del jardín central.

Este primer pliego contemplaba una intervención integral, mediante un tratamiento exhaustivo que permitiera devolverles a las construcciones el aspecto original perdido.

Superficies totales afectadas a la Intervención: Podemos tener una idea de la magnitud del proyecto integral considerando que se intervinieron a lo largo de los años $15.250 \mathrm{~m} 2$ de superficies exteriores, de los cuales $11.790 \mathrm{~m} 2$ corresponden a los edificios de Paseo Colón No 922 y 982, a los cercos y a los volúmenes posteriores que alojan a las Direcciones de Pesca y Forestal y $3.460 \mathrm{~m} 2$ a las fachadas de los dos patios interiores. 
Responsables de la intervención: Los trabajos fueron llevados adelante por la Dirección General de Administración a cargo del CPN Héctor Rodriguez quien formaba parte de la Subsecretaria de Coordinación Técnica y Administrativa bajo el mando del CPN Hugo Alberi.

Las actualizaciones tecnológicas a su vez fueron desarrolladas por la Dirección de Informática a cargo del Lic. Gabriel Melgar.

Los aspectos técnicos fueron llevados adelante por la Dirección Tecnica Operativa, contando con la colaboración de la Coordinación de Servicios Generales, del Departamento de Arquitectura y el Programa de Patrimonio Cultural del Ministerio.

Debido a que en ese momento el organismo no contaba con profesionales especializados en patrimonio arquitectónico, se contrató al Arquitecto Marcelo Magadán, Máster en Restauración de Monumentos y Especialista en Gestión de Conservación, como consultor externo.

Por su parte y dado que el conjunto está alcanzado por el Decreto $1063 / 82^{30}$, la Comisión Nacional de Museos y de Monumentos y Lugares Históricos de la Nación (CNMMLH) supervisó todo el proceso de intervención.

Una vez adjudicadas las obras, las empresas encargadas de las tareas fueron Niro Construcciones y Consulper S.A, quienes contaron a su vez con el asesoramiento de los especialistas: Gisela M. Korth y el Arq. Alberto Leonforte respectivamente.

\subsubsection{Niveles de Intervención del Inmueble}

La intervención se realizó siguiendo las etapas enunciadas a continuación, a partir de los principios de:

\section{$>$ MANTENIMIENTO \\ $>$ REPARACIÓN \\ $>$ REHABILITACIÓN \\ $>$ RESTAURACIÓN}

\footnotetext{
${ }^{30}$ El Decreto 1063/82 establece que los edificios de más de cincuenta años de antigüedad, propiedad del Estado Nacional, están tutelados por la Comisión Nacional de Museos y de Monumentos y Lugares Históricos de la Nación. (31/05/1982)
} 


\subsubsection{Etapas de Intervención}

\section{1) RECONOCIMIENTO - ESTUDIO DE ANTECEDENTES}

a) La finalidad de la intervención fue la restauración del complejo edilicio, la re-funcionalización de los espacios que habían sido modificados con el tiempo y la recuperación de todos los materiales originales degradados o perdidos.

b) Se contó como punto de partida con documentación técnica del proyecto original. A su vez con material referido a intervenciones anteriores y sus respectivos manuales de mantenimiento.

c) Se realizaron relevamientos de cada uno de los sectores a tratar, con el fin de llevar luego un seguimiento de los avances de la obra, tanto en la parte gráfica como fotográfica.

\section{2) RELEVAMIENTO DE DEFICIENCIAS Y TOMA DE MUESTRAS Y/O CATEOS a) RELEVAMIENTO DE DEFICIENCIAS}

Para el relevamiento de deficiencias se confeccionaron planos de patologías de cada edificio en formato digital, siendo la metodología aplicada para estos la enunciada a continuación:

$\checkmark$ Para relevar las patologías, se comenzó utilizando planos generales de cada una de las fachadas.

$\checkmark$ Estos planos fueron divididos en paños por niveles (del 1 al 6 ) y sectores (del 1 al 5). Sobre estos se volcaron los grafismos que identificaron cada tipo de patología. (Ver Fig. $N^{\circ} 40$ ).

$\checkmark$ A su vez se ubicó en un plano general de planta baja, cada uno de los subsectores de fachada estudiado. 
FACULTAD DE ARQUITECTURA Y URBANISMO - UNIVERSIDAD NACIONAL DE LA PLATA MAESTRÍA EN CONSERVACIÓN, RESTAURACIÓN E INTERVENCIÓN DEL PATRIMONIO ARQUITECTÓNICO Y URBANO (CRIP - FAU / UNLP)

En una planilla separada se identificaron todas las patologías según un grafismo específico. Este grafismo fue volcado a los planos de las fachadas generales. (Ver Fig. No 41 ).

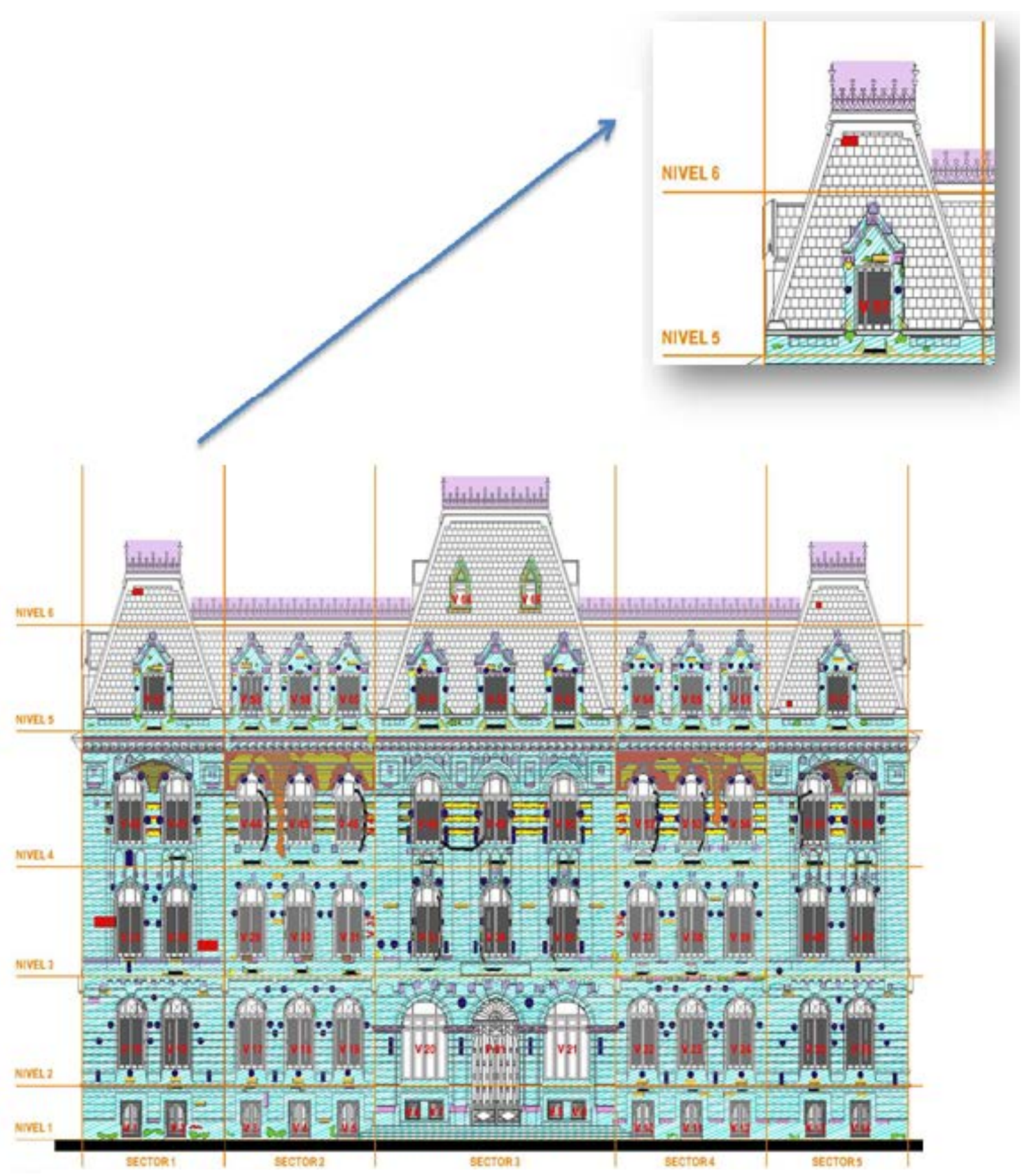

Fig. $N^{\circ}$ 40.- Plano general y detalle, elaborado en formato digital por la empresa Consulper S.A. (una de las Adjudicatarias de la obra). 


\section{REFERENCIAS}

\begin{tabular}{|c|c|}
\hline$\triangle$ & Nidos y deyecciones de Aves \\
\hline - & Degradación de molduras \\
\hline & Simil ladrillo degradado \\
\hline WIIn & Microfisuras - Superficie pintada \\
\hline & Hierros expuestos \\
\hline \multicolumn{2}{|c|}{ m Fisuras } \\
\hline$\infty$ & Revoques desprendido \\
\hline & Pizarra a reemplazar \\
\hline 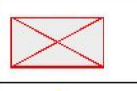 & Aire acondicionado \\
\hline & Elementos empotrados (Cañerías \\
\hline & Formación de sulfatos (Costras negras) \\
\hline & Ladrillos expuestos \\
\hline$\infty$ & Sales solubles - humedad \\
\hline & Rejillas de ventilación \\
\hline & Veladuras \\
\hline$\Delta$ & Parches cementicios \\
\hline$\triangle$ & Vegetacion invasiva \\
\hline$m$ & Gritas \\
\hline$\square$ & Erosión de la superficie \\
\hline
\end{tabular}

Fig. No 41.- Planilla General de identificación de patologías realizada por la empresa Consulper S.A.

Conjunto Edilicio Ministerio de Agroindustria de la Nación (ex Asilo Nocturno de la Capital) "Desarrollo de los instrumentos para la Conservación e Intervención del Patrimonio Arquitectónico. Hacia un Plan de Gestión". 


\section{b) TOMA DE MUESTRAS YIO CATEOS}

Antes de finalizar la redacción de las especificaciones técnicas del pliego licitatorio, las autoridades del Ministerio accedieron a contratar los servicios de la Restauradora Laura Basterrechea para que, bajo la supervisión del arqto. Magadán, hiciera algunos cateos y ensayos de retiro de las capas de pintura del símil piedra original. Se hicieron varios de estos ensayos, pero limitados únicamente al basamento de los edificios. Esto se debió exclusivamente a la escasez de tiempo y falta de fondos para pensar en armar andamios y catear en altura.

\section{3) ENSAYOS Y ANÁLISIS DE LABORATORIO SOBRE MUESTRAS EVALUACIÓN DE DEFICIENCIAS Y SUS PROBABLES CAUSALES}

Una vez iniciada la obra de intervención en el edificio de Paseo Colón № 982 a cargo de la empresa Niro Construcciones, se les solicitó que se hicieran ensayos de retiro de las capas de pintura en los paramentos que, según se sabía, habían sido aplicados años atrás. Estos abarcaron algunos sectores acotados y se llevaron a cabo sobre la cara norte.

Esta tarea fue ejecutada con el objetivo de encontrar las diferentes capas de pintura y así llegar a los materiales originales, tanto en interior como en el exterior.

Los cateos comenzaron en el interior del tercer piso y siguieron en forma descendente, terminando en el exterior efectuando pruebas de color, hasta encontrar una combinación que lograra reproducir el tono del símil piedra utilizado durante la construcción de las fachadas de los edificios.

En ambos casos se realizaron tareas de decapado en forma mecánica, empleando donde así lo requería, un gel removedor al agua trabajando por estratigrafías. (Ver Fig. $\mathrm{N}^{\circ} 42$ y 43$)$. 

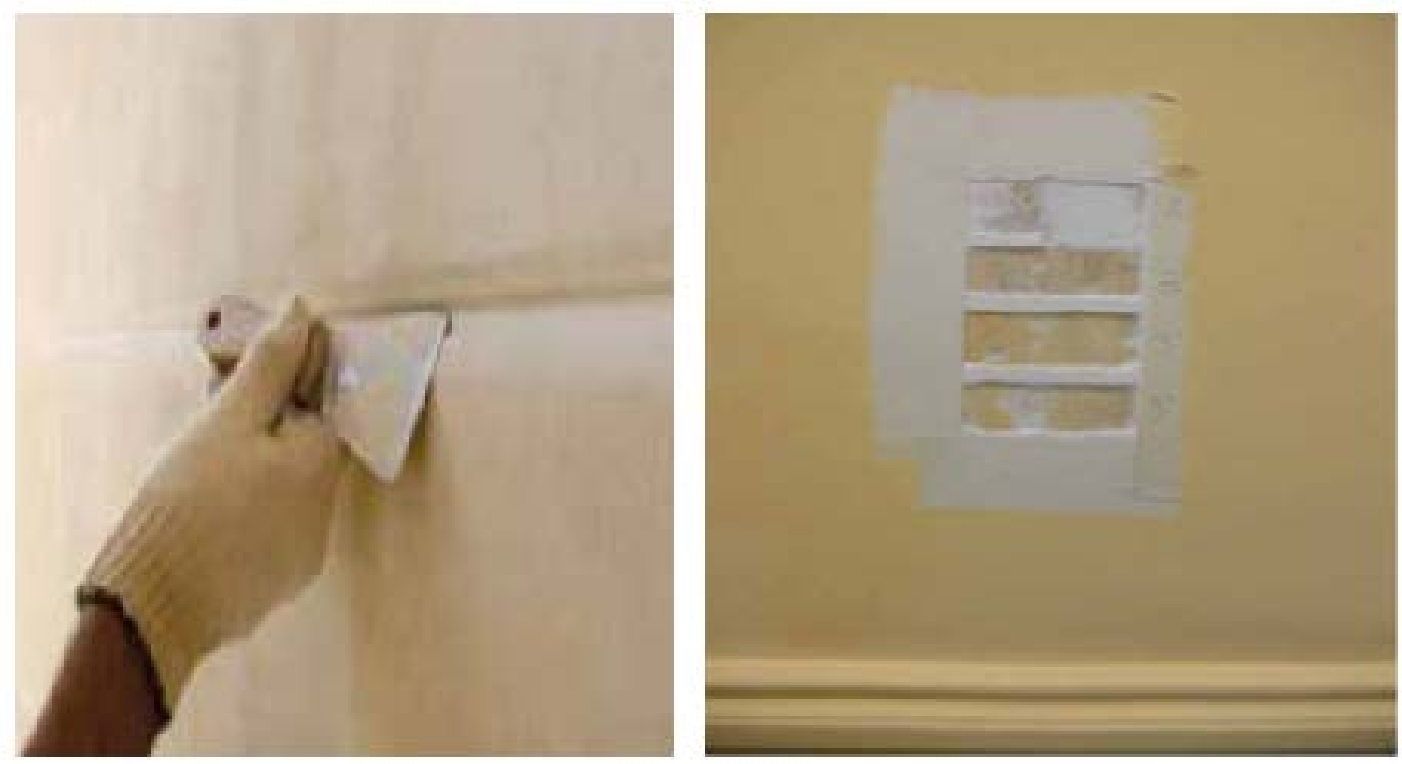

Fig. Nํㄴ y 43.- Aplicación del nuevo Símil piedra y cateos de color en muros interiores

Luego de realizados los cateos, se observó que los paramentos exteriores habían sido limpiados agresivamente y posteriormente vueltos a revocar con un material tipo enduído de cemento y pintados encima en varias capas, lo que llevó a arribar a algunas conclusiones:
a. Era posible retirar las capas de pintura con un resultado aceptable.
b. El procedimiento para lograrlo era lento.

c. La superficie del sustrato no estaba en buenas condiciones. Por ello cuando se lograba retirar la totalidad de los recubrimientos, quedaba expuesto el símil piedra original erosionado, disgregado y fisurado.

d. El costo de la tarea era elevado para lo que el Ministerio estaba dispuesto a gastar.

e. El tiempo que hubiera llevado ese trabajo excedería ampliamente el plazo previsto para los trabajos propuestos.

Por último cabe mencionar que cuando se informó la decisión a la CNMMLH de llevar adelante la obra, se le planteó la posibilidad de volver a pintar las fachadas y postergar una intervención más profunda para el futuro. Esto en espera de que se dispusiera de presupuesto, tiempo y de equipos acordes al tipo de tarea a desarrollar. Pero desde la 
CNMMLH pidieron que no se volviera a pintar y se trabajara en la recuperación de los revestimientos originales.

Dadas las circunstancias se escogió retirar las gruesas capas de recubrimientos que poseía y aplicar un revestimiento nuevo símil piedra que diera una adecuada terminación a la superficie, respetando los colores y texturas de los originales.

Esta fue una de las decisiones más importantes que se tomaron mientras se ejecutaban las tareas y que solo pudo ser evaluada una vez iniciada la obra. El criterio que se aplicó para este edificio se replicó luego para el resto. (Ver Fig. № 44 a 46).

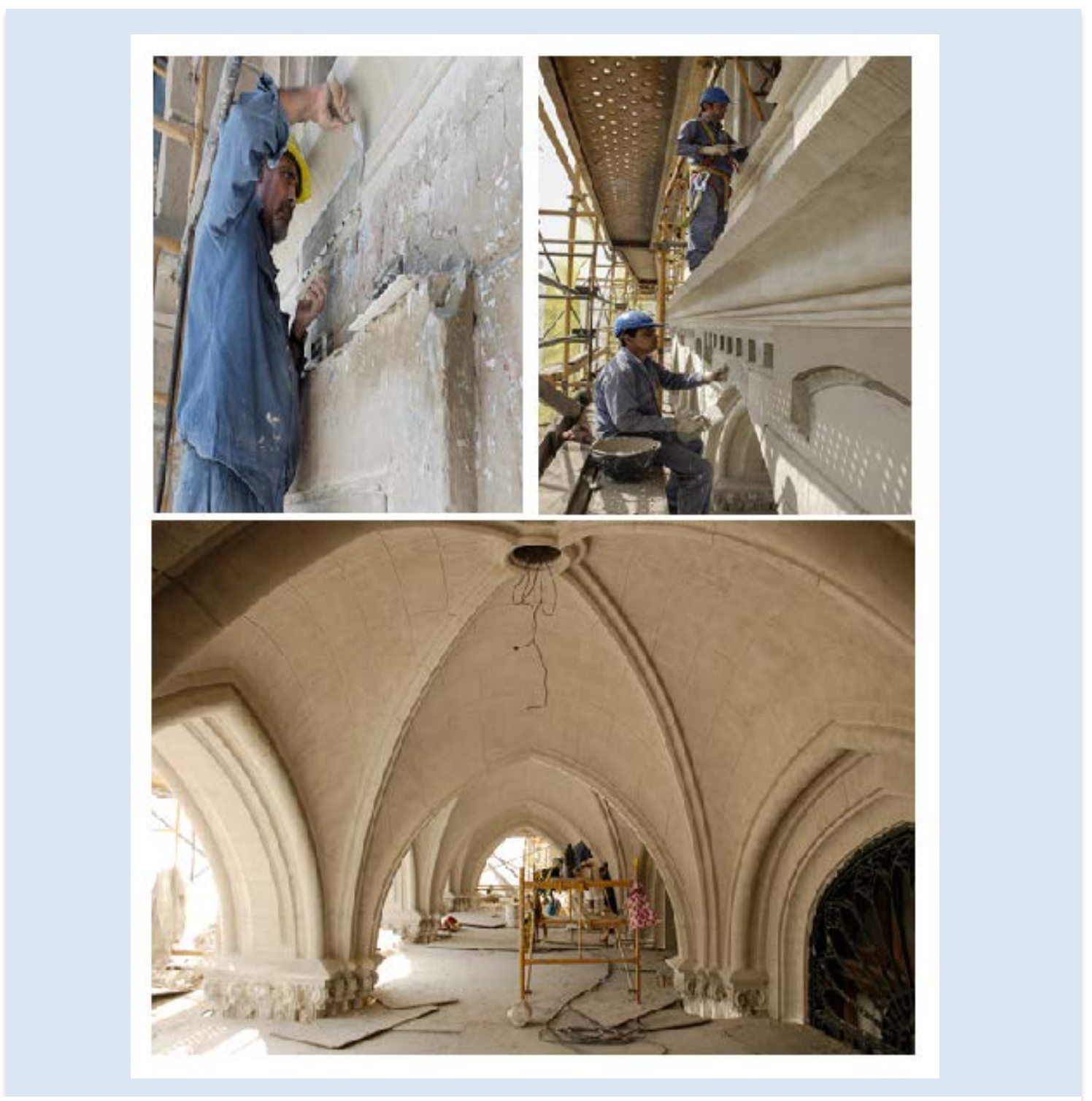

Fig. $N^{\circ}$ 44, 45 y 46.- Imágenes de los trabajos de intervención edilicia en revoques y cúpula de acceso al edificio de Paseo Colón 922. (Fotografías tomadas por la empresa CONSULPER S.A.)- Año 2012 


\section{4) METODOLOGÍAS DE LA INTERVENCIÓN SEGÚN LAS ESPECIFICACIONES TECNICAS DEL PLIEGO LICITATARIO DESCRIPCION DE LOS TRABAJOS Y CONSIDERACIONES VARIAS.}

El pliego licitatario promovía que las tareas partieran de estas premisas fundamentales:

a. Respetar los principios de mínima intervención y reversibilidad ${ }^{31}$ de las operaciones realizadas, en caso de ser necesario volver al estado anterior del bien.

b. Recurrir a la restauración, como grado de intervención, entendiendo que la misma está constituida por todos aquellos procedimientos técnicos que buscan restablecer la unidad formal y la lectura del bien cultural en su totalidad, respetando su historicidad, sin falsearlo.

c. Responder a las leyes vigentes, tanto de índole municipal como nacional e internacional en general y en este caso en relación a la accesibilidad física para todos y los medios de evacuación seguros, entre otros.

d. Lograr un mejoramiento del uso y habitabilidad de los espacios con intervenciones de adiciones simples que no compitieran con las obras patrimoniales en cuestión.

e. Liberar y demoler aquellos espacios, materiales y/o elementos agregados no originales que se encontraran alterando al inmueble y no tuvieran un valor que se correspondiera con la historicidad del conjunto.

El tratamiento de las fachadas exteriores se enfocó en la recuperación de su imagen original siguiendo las recomendaciones internacionales en lo que hace a la conservación de este tipo de edificios: mínima intervención, reversibilidad y notoriedad de las intervenciones.

El plan de trabajo consistió en dividir las fachadas por caras completas. Por ello se instalaron andamios tipo tubular en toda su longitud desde la terraza hasta el nivel de planta baja, trabajando en forma descendente, tomando las precauciones de seguridad

${ }^{31}$ PRINCIPIOS PARA EL ANÁLISIS, CONSERVACIÓN Y RESTAURACIÓN DE LAS ESTRUCTURAS DEL PATRIMONIO ARQUITECTÓNICO, ICOMOS (2003), Pto. 3.9: Siempre que sea posible, las medidas que se adopten deben ser "reversibles", es decir, que se puedan eliminar y sustituir por otras más adecuadas y acordes a los conocimientos que se vayan adquiriendo. En el caso de que las intervenciones practicadas no sean completamente reversibles, al menos no deberán limitar la posible ejecución de otras posteriores. 
correspondientes. En el caso de las fachadas exteriores que dan sobre la vía pública se colocaron pasadizos peatonales, para no interrumpir el ingreso y la circulación de las personas a través de estos. (Ver Fig. N47).

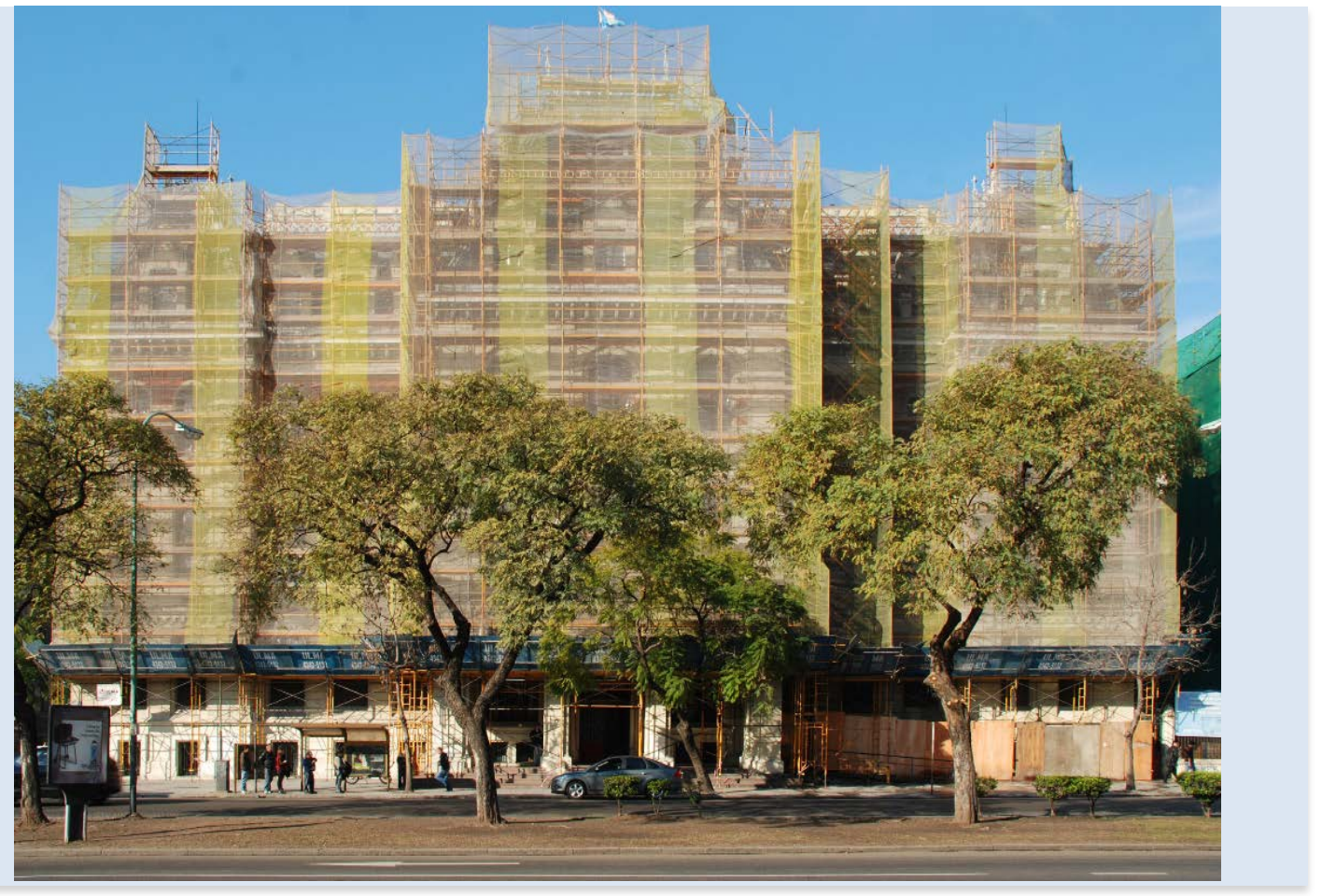

Fig. No 47.- Fachada Edificio Paseo Colon No 922 al inicio de los trabajos. (Fotografía a color de autor desconocido).

El primer paso para la Adjudicataria de cada edificio, abarcó el relevamiento y el diagnóstico de situación de las partes a intervenir, incluyendo la generación de los planos arquitectónicos de fachadas (vistas), los planos de deterioro y su respectivo registro fotográfico.

Asimismo, se debieron realizar los estudios complementarios, la toma de muestras y cateos de distintos materiales sustraídos de los paramentos para identificar la materialidad y/o los deterioros de todos y cada uno de los sectores a restaurar (según lo detallado en el Pto 3.1.3.). 
Completado el relevamiento de los distintos sectores y tomando como base las indicaciones contenidas en el Pliego de Especificaciones Técnicas, cada Adjudicataria, realizó el proyecto ejecutivo de intervención. Indicando en él, cuáles eran los trabajos que emplearía en cada lugar para corregir los deterioros existentes, así como los ensayos de comportamiento que habría de realizar antes de comenzar a aplicar los citados procedimientos en forma generalizada.

Esta información fue evaluada por la Dirección de los trabajos, la que debió aprobarla antes de que se procediera a ejecutar los ensayos de comportamiento en los edificios.

Atendiendo al valor del conjunto a intervenir, se exigió que las tareas debían estar a cargo de personas formadas y con experiencia en el tipo de intervenciones a desarrollar y se realizaran contando con los equipos adecuados, montando las protecciones requeridas destinadas a resguardar las partes originales del conjunto y tomando los recaudos necesarios para garantizar la integridad, tanto de las personas, como de los trabajos.

A su vez la totalidad de las operaciones realizadas por la Adjudicataria debían estar supervisadas por su Responsable Técnico de Rehabilitación, siguiendo, en su selección, las pautas indicadas en el Pliego de Especificaciones Técnicas. Debía registrar la información derivada de todas y cada una de las etapas de su trabajo, mediante la confección de la documentación correspondiente. Entregando un informe final que diera cuenta de lo realizado y de los resultados alcanzados. También debía entregar un Manual de Mantenimiento destinado a facilitar el correcto uso y conservación de los elementos y sus componentes.

- Extensión de los trabajos: abarcó las cuatro (4) fachadas de cada uno de los edificios con todos los elementos que las conforman, desde el solado de las aceras perimetrales hasta el nivel de cubierta inclusive. En el caso de los volúmenes principales se sumaban además la crestería de las mansardas, los paramentos internos de los muros de carga ubicados entre los remates citados y el solado de la cubierta plana del 4to piso.

- Tareas principales: las mismas se detallan en la siguiente tabla. (Ver Fig. №48). 
FACULTAD DE ARQUITECTURA Y URBANISMO - UNIVERSIDAD NACIONAL DE LA PLATA

MAESTRÍA EN CONSERVACIÓN, RESTAURACIÓN E INTERVENCIÓN DEL PATRIMONIO ARQUITECTÓNICO Y URBANO (CRIP - FAU / UNLP)

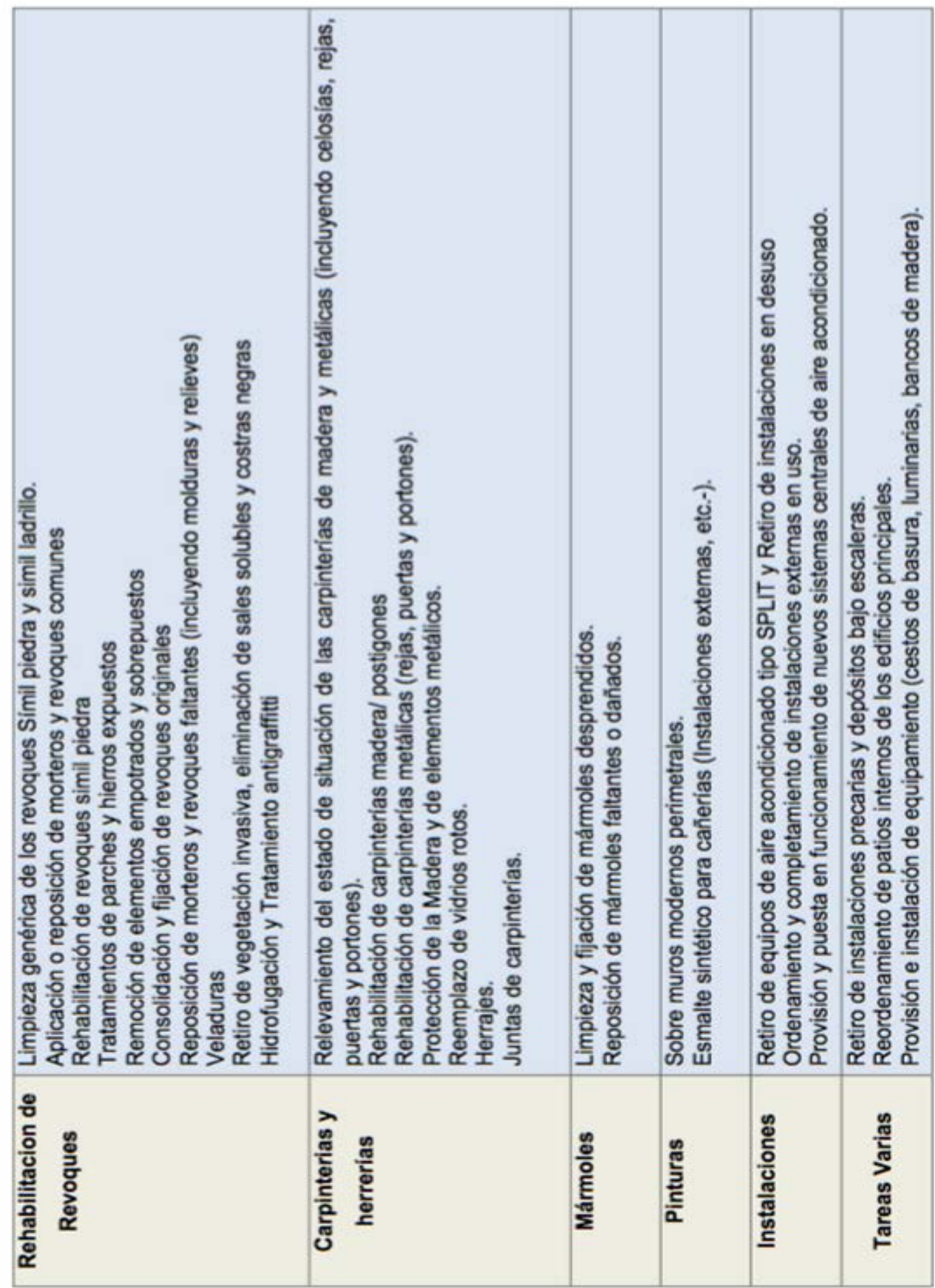

Fig. N48.- Tabla descripción de las tareas a realizar durante la intervención (Autoría Propia). 


\subsubsection{Resultados de los trabajos realizados}

\section{1) ASPECTOS POSITIVOS}

- Limpieza genérica de los revoques símil piedra: Al igual que la limpieza del símil ladrillo se efectuó mediante hidrolavado con spray de agua a baja presión con el objetivo de retirar restos de pintura, suciedad, microorganismos, carteles pegados, etc. Se empleó para ello agua limpia, libre de productos químicos o detergentes y a temperatura ambiente.

Regulando tanto el tamaño del abanico como la distancia de la lanza al paramento de la fachada para evitar dañar el recubrimiento original. A su vez el tiempo de exposición resultó de acuerdo a la resistencia que ofreciera la capa a remover.

En función de la salvaguarda del material se priorizó la aplicación de agua a menor presión, durante un lapso mayor de tiempo a efectos de alcanzar el resultado esperado. El barrido de la lanza, al lavar, se efectuó de forma tal que la limpieza resultara pareja y cubriera la totalidad de la superficie. Para la tarea se empleó personal idóneo.

- Eliminación de sales solubles y costras negras: Identificados los sectores afectados, se procedió a su eliminación por el método de compresas de $5 \mathrm{~mm}$ de espesor, empleando, como material inerte, pulpa de celulosa y agua destilada, como agente activo, dejándolas actuar hasta su secado total.

- Retiro de parches: Se procedió al retiro de todos los parches cuyas formas no respetaran la de las partes en las que fueron aplicados. En el caso de parches de cemento, como criterio general se intentó retirarlos hasta alcanzar el muro. Cuando se encontraban muy firmes, se autorizó que los mismos fueran perfilados de modo de liberar el espesor necesario para la aplicación del enlucido correspondiente (símil piedra o símil ladrillo).

- Hidrofugación: Terminada la intervención, los revoques exteriores recibieron la aplicación de un producto hidrorepelente en base a siloxanos oligoméricos de 
primera calidad: Broca BS001 o equivalente. El producto siempre fue aplicado sobre superficies limpias y perfectamente secas utilizando pincel, rodillo o pistola tipo airless.

- Tratamiento anti grafiti: La parte inferior de la fachada y hasta una altura de dos (2) metros, recibió un tratamiento anti grafiti a base a micro ceras en suspensión acuosa, mate, de primera calidad (Blocker 2, de Tecnología Antigraffiti S.A. o equivalente). A continuación, se pueden apreciar algunas fotografías tomadas por la empresa Adjudicataria durante la ejecución de las tareas mencionadas. (Ver Fig. № 49 a 52).

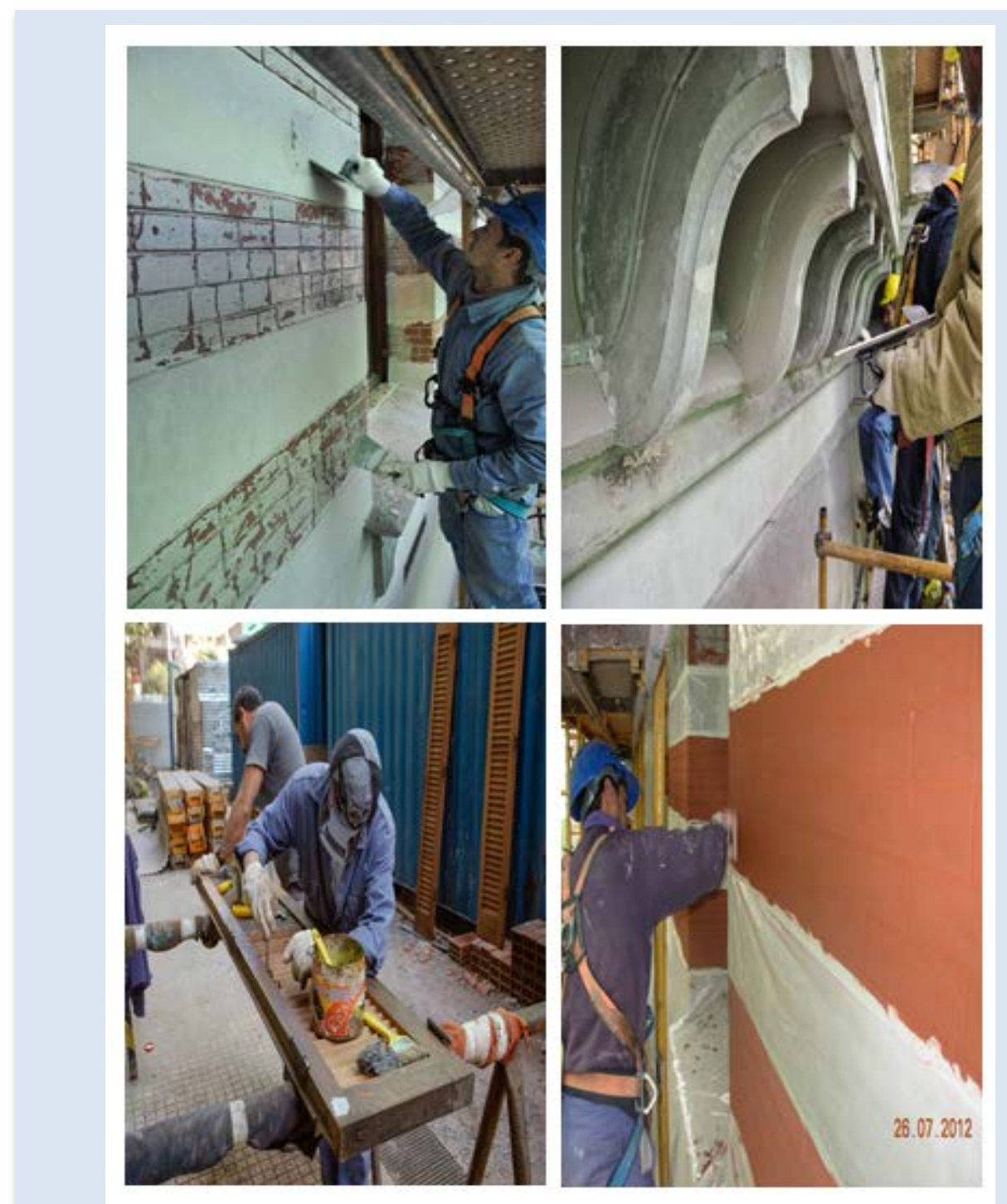

Fig. № 49 a 52.- Trabajos varios durante la intervención edilicia en muros, mansardas y carpinterías. (Fotografías a color tomadas por la empresa Consulper S.A.- Año 2012). 
- Equipos de aire acondicionado: Se procuró generar un ordenamiento del sistema de aire acondicionado de los edificios de Paseo Colón Nº 922 y 982 que permitiera retirar los equipos de ventana y Split de las fachadas que daban al exterior, en especial en lo que respecta a las calles (Av. Paseo Colón, Carlos Calvo y Estados Unidos). En los patios internos, se propuso que los equipos, e instalaciones sobrepuestas, quedaran en forma ordenada y prolija.

En primer lugar, los equipos tipo ventana que permanecían en uso fueron reemplazados por Split. En todos los casos, estos fueron colocados debajo de las ventanas del local que atendían, centrados respecto del vano. A su vez, se los unificó cromáticamente y se les colocó un contenedor metálico realizado con chapa perforada o metal desplegado de tipo industrial, sostenido por su correspondiente estructura metálica.

El escurrimiento del agua de condensación fue tenido en cuenta en el diseño del piso de los patios, de modo de evitar que chorreara sobre los paramentos de las fachadas o que pudiera molestar a las personas que transitaran por el lugar. En estos casos, los recorridos de las cañerías y los cableados de alimentación se resolvieron en el interior de los locales debiendo realizar las adaptaciones correspondientes a cada uno de ellos para que los equipos quedasen en funcionamiento.

En cuanto a los sistemas centrales empleados para el acondicionamiento de los locales situados en los anillos exteriores en reemplazo de los equipos de ventana y Split existentes, la ubicación de las unidades de tratamiento y los recorridos de cañerías se planteó de forma tal que se minimizara el impacto negativo sobre los edificios. Se tuvo especial cuidado en las acometidas del 1er piso de 982, resolviéndose desde Planta Baja o desde el 2do piso, según el caso. (Ver Fig. $\mathrm{N}^{0} 53$ y $\left.\mathrm{N}^{\circ} 54\right)$. 

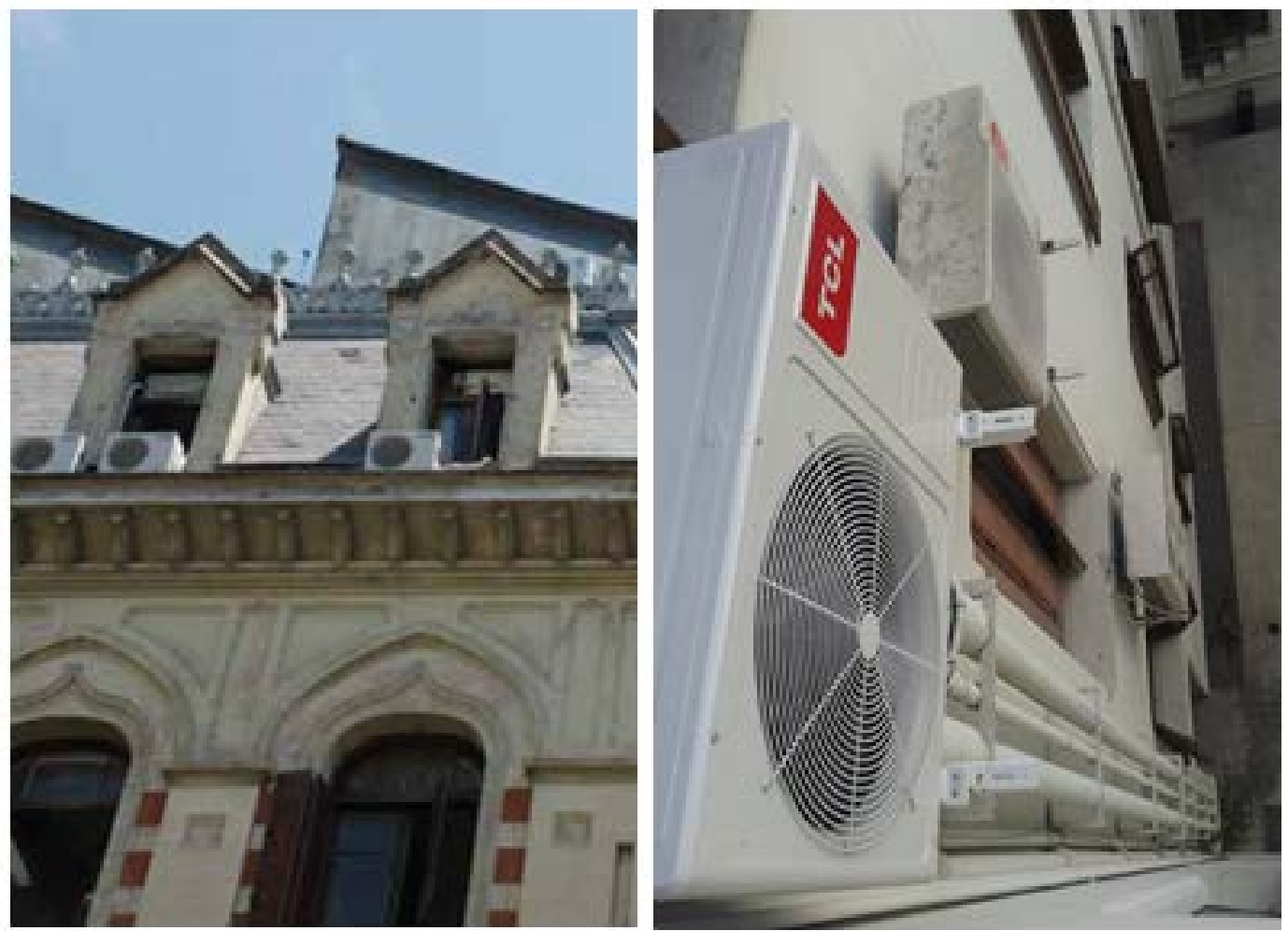

Fig. No 53 y 54.- Imágenes fachada posterior (cara este) Edificio Paseo Colon No 982 previo a las obras de readecuación y fachada interna una vez intervenida. (Autoría: Marta Casabene fotógrafa del Programa de Patrimonio Cultural del Ministerio de Agroindustria).

- Patios internos: Los patios de los dos edificios principales exhibían problemas de mantenimiento y cierta obsolescencia, en especial en el caso de las instalaciones y los servicios. A nivel de planta baja y subsuelo semienterrado presentaban construcciones de baja altura que servían de depósitos de pintura, aulas de capacitación, etc. Estas construcciones habían sido agregadas en distintas épocas. Se decidió demoler en su totalidad estos volúmenes, rediseñando los espacios para convertirlos en "plazas secas". Incorporando el equipamiento necesario para que pudieran ser utilizados por los empleados del Ministerio como área de descanso y esparcimiento.

Para ello, a comienzos del año 2013, se inició la intervención de los patios internos, unificando los niveles de piso terminado, colocando nuevo solado, rejillas de piso para el desagüe pluvial y adquiriendo nuevo equipamiento, esto es; bancos, mesas, sillas, columnas de alumbrado y vegetación. (Ver Fig. № 55 a 58). 


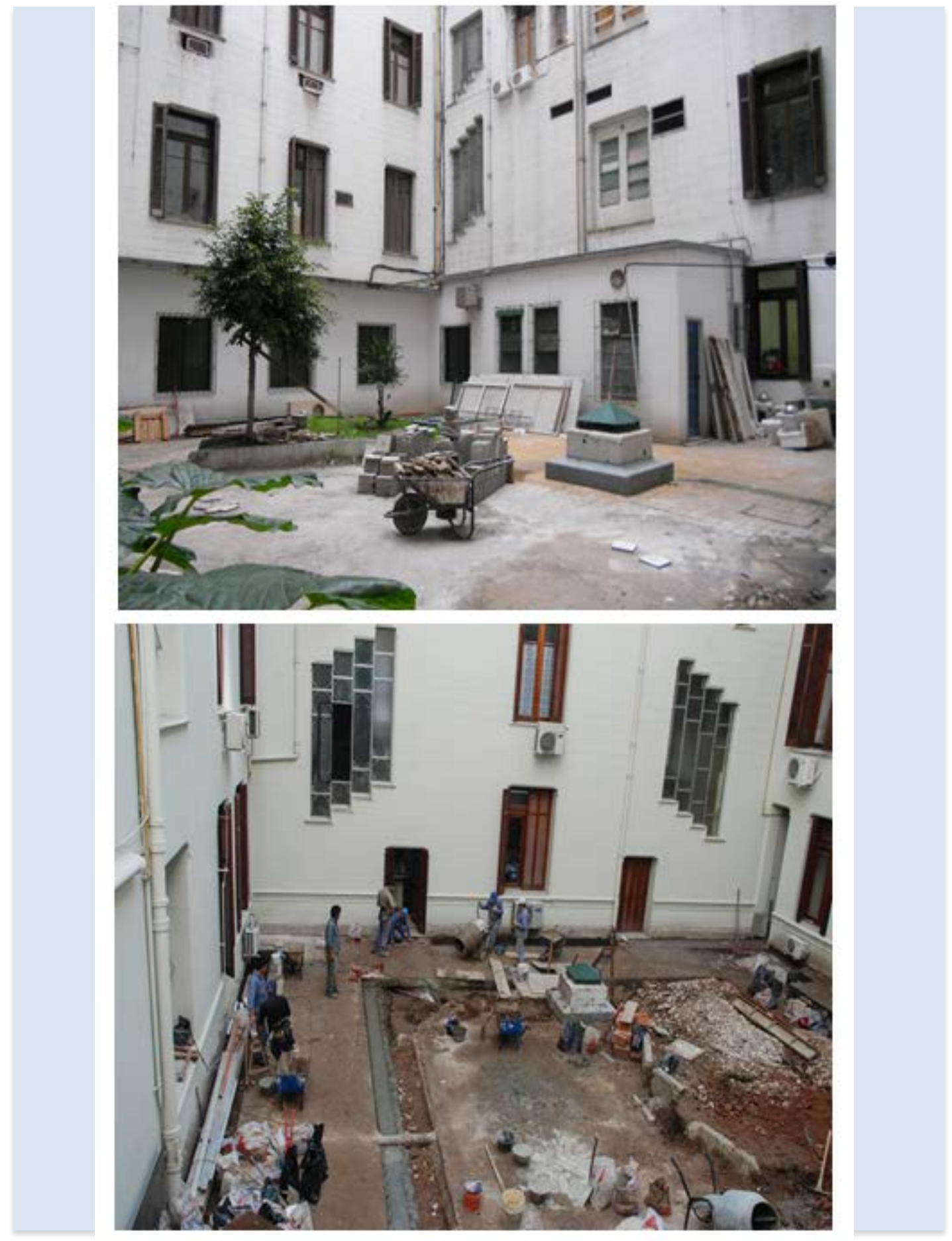

Fig. $N^{\circ} 55$ y 56.- Imágenes del estado de patio interno del Edificio de Paseo Colón Nº 982 antes de la intervención y durante la ejecución de los trabajos. (Autoría: arquitecto Marcelo Magadán- Año 2013).

Conjunto Edilicio Ministerio de Agroindustria de la Nación (ex Asilo Nocturno de la Capital) "Desarrollo de los instrumentos para la Conservación e Intervención del Patrimonio Arquitectónico. Hacia un Plan de Gestión". 
FACULTAD DE ARQUITECTURA Y URBANISMO - UNIVERSIDAD NACIONAL DE LA PLATA

MAESTRÍA EN CONSERVACIÓN, RESTAURACIÓN E INTERVENCIÓN DEL PATRIMONIO ARQUITECTÓNICO Y URBANO (CRIP - FAU / UNLP)

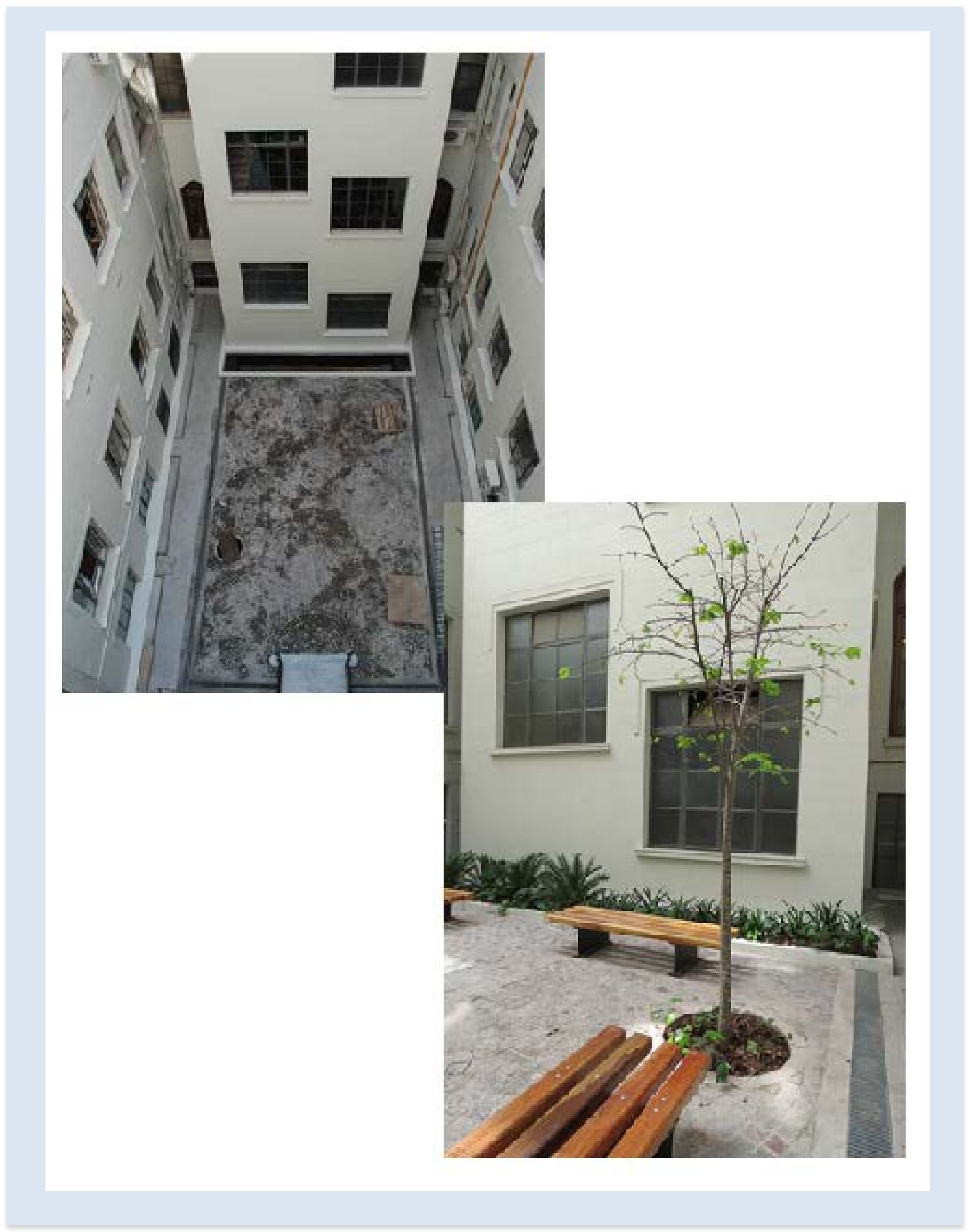

Fig. $N^{\circ} 57$ y $N^{\circ}$ 58.- Imágenes de la intervención edilicia en el patio interno del Edificio de Paseo Colón N 922, durante la ejecución de los trabajos y resultado final. (Autoría: arquitecto Marcelo Magadán- Año 2013). 
- Plantas altas: las terrazas se encontraban ocupadas con distintas construcciones que habían sido adosadas a lo largo del tiempo y provocaban la saturación del piso en cuestión.

A su vez los subsuelos que antiguamente habían funcionado como talleres, eran ahora depósitos de elementos en desuso, mobiliario con alto grado de deterioro o materiales de desecho que lo único que generaban era la atracción de múltiples roedores y un desaprovechamiento de los espacios de guardado.

- Cables, materiales eléctricos y cañerías: junto con los trabajos de restauración de las envolventes, se hizo un relevamiento de todos los cables y los caños que se hallaban sobre las fachadas. Aquellos que estaban en desuso fueron retirados y se reordenaron los que aún estaban en funcionamiento.

- Carpinterías: todas fueron intervenidas en los obradores que las empresas montaron dentro del predio. Como criterio general se cerraron los vanos abiertos producto de anteriores reformas internas, como ocurrió en la parte alta de la fachada Oeste de Paseo Colón № 982. Así mismo se abrieron las que fueron cerradas parcial o totalmente, tal los casos de los vanos de las escaleras de la citada fachada y del lado Sur del patio. También se cerraron los vanos correspondientes a los equipos de aire acondicionado que se encontraban empotrados.

Respecto de los vidrios, se trató de respetar el esquema original, manteniendo todas las ventanas que habían tenido vidrio estampado con ese mismo tipo de material (cajas de escaleras, sanitarios, etc.). Una vez retirados los vidrios, se procedió a evaluar la posibilidad de reunir los que se hallaban sanos para colocarlos en un mismo sector, quedando como testimonio de la situación original del patio.

- Escaleras de mármol: La totalidad de las escaleras interiores principales de los edificios con peldaños de mármol fueron restauradas. Como primera medida se comenzó realizando una limpieza destinada a eliminar la suciedad superficial. Los faltantes parciales fueron repuestos mediante la aplicación de incrustaciones realizadas con un material similar al original. 
Este mismo criterio se siguió cuando hubo que reponer piezas completas. Los elementos subsistentes que así lo requerían fueron consolidados.

Para optimizar costos de mantenimiento, se sugirió reemplazar las bandas antideslizantes pegadas por otras de tipo permanente, pero esto no fue puesto en práctica.

Se demolieron las construcciones menores bajo escaleras que no eran originales y se constituían como depósitos altamente precarios. Se liberaron así los espacios ocupados.

En el caso de los patios internos se reconstruyeron las molduras y las texturas perdidas que habían quedado tapadas debajo de las construcciones mencionadas.

- Espacios Interiores de los edificios, se comenzó tempranamente con dos intervenciones: la primera estuvo relacionada con todo lo referente a la actualización tecnológica. Se renovaron las instalaciones, anexando redes de datos, comunicación, detección de incendio, seguridad por sistema cerrado de televisión, audio, evacuación y seguridad de accesos, incorporando nuevas salas técnicas por piso.

- Pasillos: En el caso de los muros interiores, se consideró necesario repintarlos en su totalidad. Para ello se sugirió volver a los colores originales, los que deberían determinarse a partir de la realización de cateos en diferentes sectores de los pasillos de cada uno de los pisos. Seguidamente se debieron realizar las pruebas de colores para concretar los ajustes cromáticos correspondientes.

- Los cielorrasos de los pasillos, que habían sido bajados mediante la colocación de diferentes sistemas de placas, volvieron a recuperar su altura original.

- Sanitarios y cocinas (Paseo Colón No 922 y 982). Dado que tanto los baños como las cocinas existentes no eran originales o habían sido modificados perdiendo los componentes primigenios, se propuso que se intervinieran actualizándolos de acuerdo a la demanda y a la normativa vigente. 
En todos los casos se respetaron los vanos originales, tanto los que correspondían a las ventanas que daban a los patios, como las puertas hacia los pasillos. Esto también fue válido para las puertas de los baños de discapacitados que debían construirse asemejándolas a las existentes en el entorno inmediato del lugar que correspondiera, incluyendo nueva señalética y rampas.

- Readecuación del edificio que ocupó la Dirección Nacional de Coordinación Pesquera en la parte posterior del conjunto (cara Noreste) para trasladar allá a la biblioteca central del Ministerio. También se trabajó en la rehabilitación de las construcciones donde funcionaban las Direcciones de Producción Forestal y la de Pesca, ubicados sobre la esquina de las calles Azopardo y Carlos Calvo.

- Remates: fueron intervenidos posteriormente, cuando se contrató la adecuación del cuarto (4to) piso, a partir de lo cual se trató la mansarda realizando la revisión de la totalidad de las pizarras verificando su estado de condición y ubicando las que debían ser recambiadas. Luego se procedió a la reposición de las pizarras faltantes o fracturadas empleando nuevas de una tonalidad similar, equiparando además tamaño y espesor. También se procedió a la fijación de las desprendidas.

Una vez finalizados los procedimientos de recambio de piezas y reparaciones de cubiertas, se verificó la estanqueidad de las mismas.

Se trataron los remates de plástico reforzado con fibra de vidrio (PRFV) mediante limpieza, reposición de faltantes, tratamiento de uniones, lijado y pintura.

Los escudos, las placas conmemorativas esmaltadas y las mayólicas fueron tratados con las especificidades particulares que cada uno de los sustratos constitutivos requirió.

- Cercos exteriores también se intervinieron junto con las puertas metálicas de ingreso al predio, ubicadas sobre la cara este del conjunto y las rejas ubicadas delante de las carpinterías del subsuelo semienterrado de los edificios. En todos los casos se realizó un relevamiento previo del estado de situación de cada pieza, interviniendo en los deterioros que estas presentaban. Se restauraron respetando el color original de las mismas dándoles siempre una protección final. 
Si bien los tratamientos en cada edificio intervenido fueron diferentes, se procuró apelar a un criterio unificador que lograra un lenguaje común para todos los sectores del conjunto.

Las obras se llevaron a cabo con el complejo en funcionamiento, por lo que las tareas se facilitaron gracias a la buena voluntad y a la comprensión de todo el personal del entonces MAGyP que de una u otra manera veían afectado el normal desarrollo de sus actividades.

\section{2) ASPECTOS NEGATIVOS}

\section{- Tratamiento de lluminación de fachadas ${ }^{32}$}

En enero del año 2014 el arquitecto Magadán fue consultado en relación al proyecto de iluminación de las fachadas principales del conjunto edilicio.

A partir de dicha consulta elaboró un informe que fue recibido por las autoridades del Ministerio el 20 de enero del citado año. Sin embargo, hasta la fecha no hubo avances en este sentido.

A continuación se detalla el contenido del informe que parte de la base de considerar lo que las recomendaciones internacionales indican, en relación a que la percepción nocturna de los edificios históricos iluminados debe ser lo más parecida posible a la que de ellos se tiene durante el día.

Dentro del enfoque teórico del tema y de los distintos documentos que tratan el asunto el especialista menciona a las "Normas de Conservación Preventiva para la Implantación de Sistemas de lluminación en Monumentos y Edificios Históricos", del Instituto del Patrimonio Histórico Español del Ministerio de Cultura de España y la "Carta de Taxco", del Instituto Nacional de Antropología e Historia (INAH), México.

Al respecto, esta última dice:

32 Arqto. Magadán M., Informe interno Ministerio Agroindustria. 'La Iluminación de las fachadas del MAGyP”. 20/01/2014. 
"El tema de la implantación de luz artificial en los monumentos y centros históricos como un acto meramente contemplativo y ambiental es un fenómeno relativamente nuevo [...] es por ello que ante esta gran demanda que crece día a día, se requiere inducir y capacitar a cada vez más número de profesionistas, entre arquitectos, historiadores, urbanistas, restauradores, ingenieros, incluso al mismo cuerpo clerical y a usuarios. Retroalimentarnos de los atinados ejemplos que existan en otras ciudades del mundo, con el objeto de evitar y frenar el deterioro a los monumentos [...] con instalaciones y proyectos inadecuados de iluminación; asimismo promover intervenciones que se realicen en absoluto apego y respeto a la historicidad y estética de los mismos". ${ }^{33}$

Ese mismo documento en relación a la "lluminación Exterior" de los edificios, plantea un concepto clave cuando expresa:

"El proyecto propuesto deberá proporcionar al inmueble una iluminación UNIFORME, que permita apreciar la UNIDAD de la obra y que evite su apreciación distorsionada y fraccionada."

En función a llevar a cabo la aplicación de estos conceptos a los edificios históricos del Ministerio el consultor enfatiza la necesidad de analizar la iluminación desde el punto de vista de la conservación, en especial, teniendo en cuenta los aspectos estéticos y paisajísticos del conjunto. Incluyendo la provisión e instalación del sistema de iluminación en las mansardas y a los laterales de los volúmenes salientes que corresponden a los accesos sobre la Av. Paseo Colón No 922 y 982.

Buscando lograr una "iluminación uniforme", lo más semejante posible al efecto de la luz natural, de manera tal que permitieran apreciar la "unidad de la obra" y que evitaran su distorsión y/o fraccionamiento.

En cuanto a la instalación y las cuestiones operativas el arquitecto plantea en su informe la necesidad de trabajar con personal entrenado y disponiendo de medios de acceso al lugar de trabajo (como andamios, plataformas elevadoras o brazos hidráulicos) que no entraran en relación directa con las fachadas debido a que la textura del revestimiento podría alterarse fácilmente por acción mecánica (presión o roce). Con respecto a la

${ }_{33}$ INAH; "Carta de Taxco", Instituto Nacional de Antropología e Historia, México, 2009: "Antecedentes".

\footnotetext{
Conjunto Edilicio Ministerio de Agroindustria de la Nación (ex Asilo Nocturno de la Capital) 
ejecución de la instalación del sistema, el informe establecía que había que tener en cuenta que los artefactos debían montarse sobre ménsulas metálicas de acero inoxidable y contar con un recubrimiento adecuado para exteriores (epoxi o pintura termoconvertible) del mismo color de los artefactos.

Las ménsulas estarían diseñadas y construidas de forma tal que se facilitara el mantenimiento de los artefactos y debían servir para colocar tantos artefactos como resultara posible en cada punto. Se asegurarían a las partes verticales mediante fijaciones químicas.

El cableado de alimentación solo se colocaría dentro de caños galvanizados. No admitiendo el pegado de conductores sobre el recubrimiento ya que lo dañaría irreversiblemente ni admitiendo el empleo de caños plásticos en la medida que se deforman y/o fragilizan por efecto del sol. Siendo únicamente permitidos los tramos de caños rectos sin codos o curvas.

Los caños galvanizados y las partes visibles de los cables se pintarían del color del muro previo a proceder a su colocación en la fachada evitando manchas y chorreaduras de pintura.

Las acometidas desde el interior del edificio se darían en la menor cantidad de lugares posibles buscando atenuar el impacto visual y tendrían una leve pendiente hacia el exterior, de modo de impedir el ingreso de agua de lluvia a los locales.

En los sectores de mampostería, las perforaciones para las acometidas serían realizadas desde el exterior hacia el interior, de modo de minimizar el daño sobre el revestimiento de las fachadas. Mientras que, en las mansardas, se darían a través de los faldones de pizarras, colocando las piezas de zinguería que permitieran el paso de los conductores e impidiendo el ingreso de agua de lluvia al interior de los locales.

\section{- Los árboles del Ministerio como Patrimonio paisajístico ${ }^{34}$}

Fue también durante el año 2014 que la caída de una rama de uno de los gomeros (ficus) del jardín interno del Ministerio originó una poda excesiva del mismo y la amenaza de tala

34 Arqto Magadán M., 15/01/2014, Informe: "Los árboles del MAGYP como Patrimonio paisajístico." 
de otros árboles lo que motivó al arqto asesor Magadán a presentar un nuevo informe. Esto en relación a comentarios, que hablaban de una tala que abarcaría a este y otros árboles, incluyendo los dos gomeros ubicados sobre la línea municipal en el frente que da a la calle Estados Unidos, los que habrían sido plantados por los años 1945/50, durante la administración de Juan Domingo Perón. Por tanto se trataba de ejemplares de unos sesenta (60) años de antigüedad.

Entendiendo que, la caída de las ramas podían evitarse realizando las podas correctivas recomendadas de acuerdo a la especie de que se tratara. Además del impacto que implicaría la pérdida de estos ejemplares, su mutilación y/o tala dejando a la vista construcciones cuya calidad estética no era relevante.

Basándose en diferentes recomendaciones internacionales, el arquitecto aconsejaba procurar la asistencia de especialistas que pudieran hacer un correcto diagnóstico de la situación de cada uno de los arboles del parque, procediendo a realizar las postergadas podas correctivas. Más allá de eso afirmaba que, cualquier decisión que se tomara debía considerar las otras variables en juego que hacían a los aspectos patrimoniales del conjunto y que ese tipo de acciones debían concretarse solo como última medida ante situaciones extremas que no pudieran ser remediadas de otro modo.

A pesar que en el informe quedaba demostrado que dichos árboles integraban una unidad paisajística con los edificios históricos y tenían valor ambiental, poco tiempo después fueron retirados del predio.

\subsubsection{Conclusiones parciales}

El enfoque integral adoptado para abordar la problemática del conjunto sirvió como punto de partida esencial del proceso de intervención. Ya que aportó la información indispensable y el estado particular en que se encontraba al momento de iniciar los trabajos.

Resulta fundamental este procedimiento de trabajo dividido en etapas para comprender la problemática del sitio y establecer una metodología en relación a la situación real de los inmuebles y sus necesidades individuales. 
Así tareas como cateos y ensayos de laboratorio aportaron los datos específicos y veraces de la composición de los materiales utilizados originariamente para poder replicarlos siguiendo sus idénticas cualidades.

Sin dudas, los resultados obtenidos a partir del trabajo multidisciplinar realizado, fueron satisfactorios, tanto en lo que refiere a las envolventes, como a los tratamientos efectuados en los espacios interiores.

Sin embargo, algunas situaciones no atendidas oportunamente han traido consigo múltiples consecuencias negativas.

Esto es por un lado en lo referido a la demora en la incorporación de nueva iluminación en las fachadas lo que ocasionó que quedaran a oscuras durante la noche, fomentando los hechos de vandalismo, y dejando al sitio en un inevitable estado de desprotección.

Por otro lado el retiro de parte de los árboles del jardin interno, no solo fue injustificado sino que además se constituyó como una pérdida irreparable.

\subsection{Aspectos no contemplados en la intervención y situación actual}

\subsubsection{Patologías y deficiencias varias}

Hoy a pocos años de la culminación de las tareas de restauración y puesta en valor del complejo, se evidencian nuevas patologías que deben ser tratadas a la brevedad para detener el avance de las mismas y mantener los edificios en óptimo estado de conservación. Los deterioros se deben fundamentalmente a las siguientes causas: por un lado, hechos vandálicos verificables a través de pegatinas y grafitis alojados en todo el perímetro de las fachadas principales. (Ver Fig. № 59 y № 60). Esto sumado a los daños causados por problemas de humedades en muros, por obstrucción de canaletas y falta de limpieza o mantenimiento. Estas deficiencias y otras también encontradas serán analizadas detenidamente en el capítulo siguiente. 


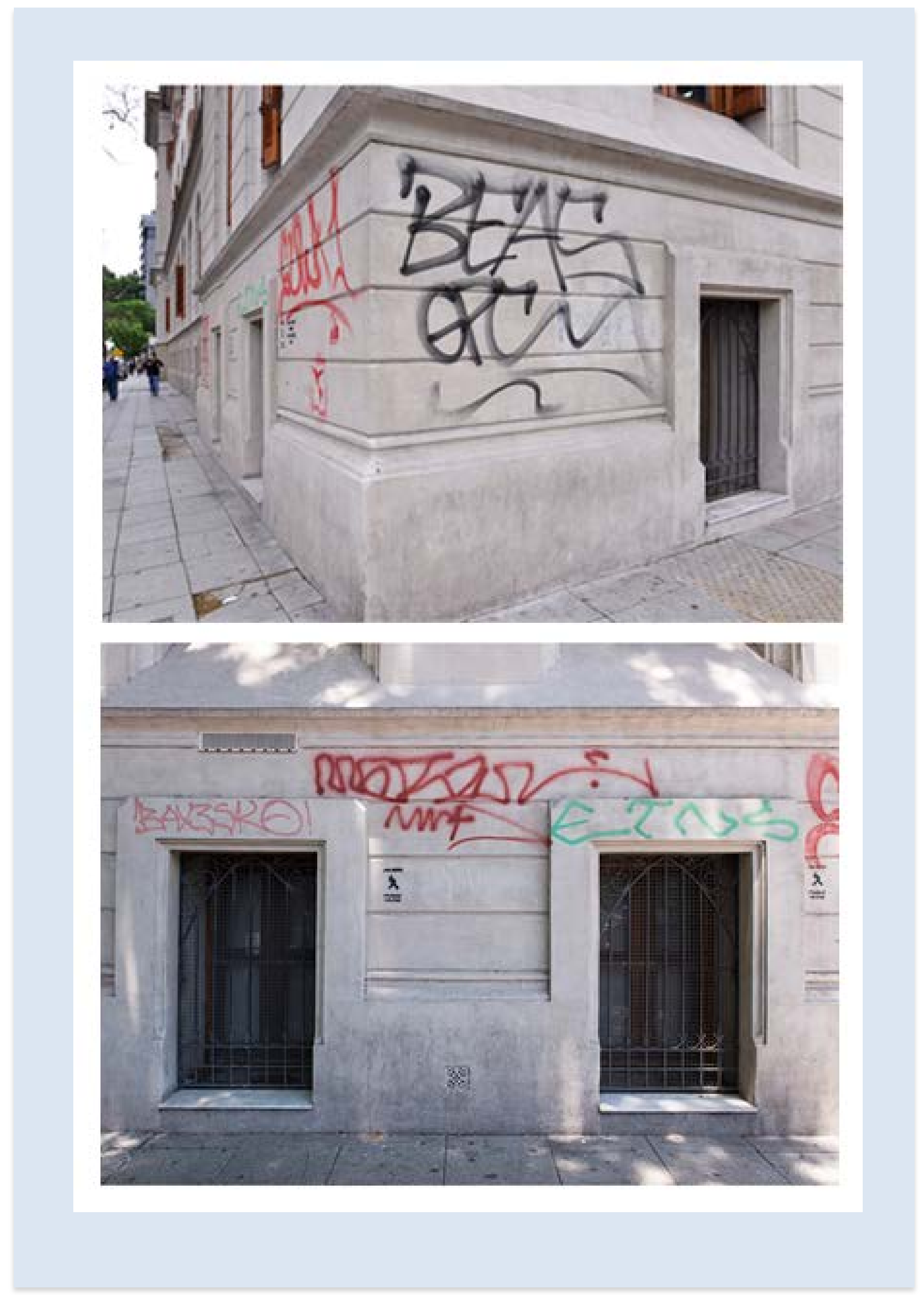

Fig. N59 y 60.- Imágenes en detalle de basamentos con grafitis en la esquina de Paseo Colón y Estados Unidos. Gentileza de la fotógrafa Marta Casabene del Programa de Patrimonio Cultural del Ministerio. Fecha de registro 08/11/2016.

Conjunto Edilicio Ministerio de Agroindustria de la Nación (ex Asilo Nocturno de la Capital) "Desarrollo de los instrumentos para la Conservación e Intervención del Patrimonio Arquitectónico. Hacia un Plan de Gestión". 


\subsubsection{Conclusiones parciales}

El avanzado estado de deterioro del conjunto edilicio y la variedad de patologías que presentaba, requerían un abordaje integral del tipo de intervención que se debía realizar. Por ello se hizo necesario dividir las tareas en distintas etapas, involucrando a todos los edificios, esto es; los dos (2) principales con frente sobre Paseo Colón y sus anexos sobre la cara este del predio. Se decidió iniciar los trabajos atendiendo las envolventes de los mayores en sus cuatro (4) caras y las fachadas internas correspondientes a los patios que dan al pulmón de cada uno de ellos.

La magnitud de las superficies afectadas demandó un estudio profundo que debía contemplar situaciones diversas según los sectores a tratar, no solo por la diferencia estilística de cada edificio, sino también porque habian sido construídos en distintos momentos y poseían una materialidad diversa.

El punto de partida fue de la concepción de que el trabajo debía regirse por cuatro (4) niveles de intervención que darían forma a las tareas a cumplir, referidos al mantenimiento, la reparación, la rehabilitación y la restauración edilicia.

Se estableció así un ordenamiento de las tareas entendiendo que previamente era imprescindible realizar un relevamiento exhaustivo, registrando el estado de situación de cada una de las partes constitutivas del conjunto.

En este contexto de tanta diversidad fue necesario unificar criterios para lograr una armonía entre las partes ya que se trataba de una labor altamente compleja desde todo punto de vista. No solo por las características propias del bien a intervenir sino además porque las obras serían ejecutadas por dos empresas diferentes y mientras el Ministerio continuaba funcionando a pleno.

Con este escenario por delante, cabe mencionar la importancia de contar con especialistas en el campo patrimonial en cada uno de los roles principales de este emprendimiento. 
Esto es tanto para el asesoramiento en la redacción de los pliegos licitatorios, como para el control de la obra en general, además de exigir la participación de especialistas que debían ser contratados por cada una de las empresas Adjudicatarias. Por último desde la CNMMLH ejerciendo la tutela permanente sobre el bien patrimonial según había sido catalogado años atrás.

Es indudable que los resultados obtenidos responden a la expertise de estos profesionales en cada una de sus tareas.

\subsection{Conclusiones}

Según lo expuesto a lo largo del capítulo, hacia el año 2010 se comienza a trabajar en la puesta en valor y readecuación del conjunto edilicio. Tarea que respondió a distintos llamados de licitación y demandaría varios años debido a la magnitud que los deterioros habían adquirido con el paso del tiempo y los estudios que se fueron realizando para definir cuales eran los procedimientos más adecuados a ejecutar.

Hoy poco tiempo ha pasado desde que el Ministerio vió finalizado ese extenso proceso y a pesar de ello, se evidencian nuevos deterioros, muchos de los cuales podrían haberse evitado. Esto teniendo en cuenta que las empresas Adjudicatarias luego de finalizar las obras entregaron a la DTO sus respectivos manuales de mantenimiento, especificando todas las medidas que debían tomarse en cuenta para conservar el bien en óptimas condiciones.

Resulta además difícil de comprenden las decisiones tomadas por las autoridades del organismo quienes, desestimando las tareas estipuladas en los pliegos de licitación para revertir daños existentes y luego que fueran ejecutadas por las empresas contratadas a tal fín, reinciden nuevamente en procedimientos inadecuados.

Lo que implica también subestimar las indicaciones vertidas en los manuales mencionados como así también en los informes oportunamente presentados por el asesor cuyo servicio ellos mismos habían solicitado tiempo atrás.

\footnotetext{
Conjunto Edilicio Ministerio de Agroindustria de la Nación (ex Asilo Nocturno de la Capital) 
Un ejemplo de esto son las instalaciones de nuevas unidades de aire acondicionado sobre las fachadas interiores, cuando oportunamente se optó por retirar todos los equipos existentes procurando devolverles a los paramentos su lectura original, libre de elementos añadidos en etapas posteriores.

En lo que respecta a los aspectos negativos mencionados, estos están relacionados con situaciones no contempladas durante los años que duró la intervención del conjunto. Es decir aquellas deficiencias que se resolvieron de manera incorrecta, o que se decidió postergar para resolver a futuro dejando que dichos problemas avanzaran sin subsanarlos a tiempo.

Es decir que, la totalidad de las tareas que fueron pautadas durante el proceso de intervención edilicia, contando con todo el equipo de trabajo en obra, se desarrollaron dando resultados positivos.

Vale la pena señalar entonces que, el éxito alcanzado fue también producto de la labor de personal idóneo y un equipo interdisciplinar de especialistas en patrimonio edilicio. Esto evidencia la necesidad de contar en forma permanente con expertos patrimonialistas dentro de los equipos de mantenimiento de las entidades que ocupan edificios históricos, a fin de generar nuevas herramientas y controles periódicos sobre los bienes.

Continuando con lo relatado y entendiendo las nuevas deficiencias del conjunto, surge la necesidad de llevar a cabo un relevamiento minucioso de la situación del bien, tanto a nivel de las envolventes como en los interiores. Realizando como primer medida un reconocimiento visual para detectar las patologías y los deterioros existentes determinando un nuevo plan de acción.

Comenzando a tomar intervención en aquellas situaciones que requieran una atención urgente (ir de lo más grave a lo más leve, de lo general a lo particular) preparando las especificaciones técnicas que integren un nuevo pliego general de licitación en caso que esto fuera necesario. Esto último será desarrollado en el capítulo siguiente. 


\section{Capítulo IV.- IDENTIFICACIÓN DE PATOLOGÍAS Y DESAJUSTES}

Introducción:

Según ha sido descripto en el capítulo anterior, la intervención edilicia demandó varios años de arduo trabajo con un abordaje particularizado acorde a las características propias de cada edificio a tratar.

El presente capítulo tiene por objeto analizar la evolución del conjunto edilicio a partir de la finalización del proceso de rehabilitación. Por cuanto se entiende que, más allá de todas las premisas que deben tenerse en cuenta al ejecutar una obra de semejante envergadura hay distintos factores que deberían tomarse en cuenta a posteriori para garantizar el mantenimiento de las mejoras logradas.

Por ello se detallarán los sucesivos relevamientos realizados en el conjunto, describiendo las patologías y problemas que se fueron registrando. Incluyendo los desajustes en cuanto a cuestiones vinculadas a la funcionalidad de algunos sectores y en particular referido a los medios de evacuación desde los pisos superiores hacia la planta baja.

Todo esto con el fin de evaluar y determinar los trabajos que deberían ejecutarse para revertir las deficiencias que los inmuebles presentan actualmente.

Esto se acompañará de una serie de recomendaciones que deberían impartirse a los usuarios de las oficinas y las empresas tercerizadas que presten servicio dentro del conjunto.

Por último, se pretende confeccionar una metodología de mantenimiento preventivo del bien para asegurar su perdurabilidad a largo plazo. 
Preguntas claves:

¿Cuáles son los deterioros y las patologías que se registraron en estos últimos años? ¿Cuál es la situación actual del conjunto edilicio a pocos años de la intervención realizada?

¿Cuáles son las medidas que deberían llevarse a cabo para revertir los desajustes encontrados?

\subsection{Situación actual del conjunto edilicio.}

4.1.1. Patologías principales encontradas en elementos constructivos hasta año 2017

4.1.2. Informe de seguridad de fachadas - junio de 2019

4.1.3. Problemática en terraza del 4to piso edificio Paseo Colon $N^{\circ} 982$

4.1.4. Conclusiones parciales.

\subsection{Planteo de soluciones a las situaciones encontradas}

4.2.1. Trabajos de intervención edilicia.

4.2.2. Pautas de mantenimiento preventivo.

4.2.3. Conclusiones parciales.

\subsection{Conclusiones}




\subsection{Situación actual del conjunto edilicio}

Según lo expuesto en el capítulo anterior, en líneas generales el resultado final obtenido de las tareas de intervención y rehabilitación integral realizadas en el conjunto fue ampliamente satisfactorio. Las fachadas que mostraban un avanzado estado de deterioro por suciedad, costras negras y alteraciones de las superficies de los revestimientos, fueron atendidas como así también los desajustes que se presentaban en los distintos sectores tanto interior como exteriormente.

Al concluir las obras, cada una de las empresas contratadas para la puesta en valor de los edificios, entregó un manual de mantenimiento a la dirección tecnica operativa del Ministerio (DTO). Esto a fin de garantizar la continuidad del cuidado de los inmuebles en base a los criterios de conservación previamente establecidos y detallando todas las medidas que debían tomarse en cuenta para mantenerlos en óptimas condiciones.

Aun así y a pesar de haberle dado respuesta a un número significativo de necesidades de mejoras del conjunto, se observan distintas problemáticas que requieren pronta atención. Esto es principalmente debido a múltiples situaciones que serán formuladas oportunamente.

A continuación, se realizará un análisis pormenorizado del edificio Paseo Colon № 982 aclarando que, salvo la problemática del 4to piso que es exclusiva de éste, el resto de las situaciones se repiten en su gemelo. Por lo tanto y más allá de ser el inmueble elegido para el presente análisis, las soluciones que se planteen luego podrán ser aplicadas al resto del conjunto.

4.1.1. Patologías principales encontradas en elementos constructivos hasta año 2017

I. Grafitis y restos de pegatinas de afiches

Se observan grafitis de distintas dimensiones y variedad de colores que están pintados, mayoritariamente en aerosol en toda la extensión del basamento de símil piedra.

También se pueden observar pegatinas y restos de afiches sobre las superficies de los paramentos y en las pilastras de ingreso a los dos edificios principales.

Es difícil conocer con exactitud la antigüedad que los grafitis poseen, pero los mismos se comenzaron a registrar a partir del mediados del año 2014. 
Cabe aclarar que los basamentos poseían una pintura antigrafiti, hasta $2 \mathrm{mts}$ de altura la cual había sido colocada durante el último proceso de intervención edilicia. Sin embargo, al comienzo de los primeros relevamientos ya se podían visualizar sectores en donde la aplicación se veía deteriorada. (Ver Fig. № 61 a 63).

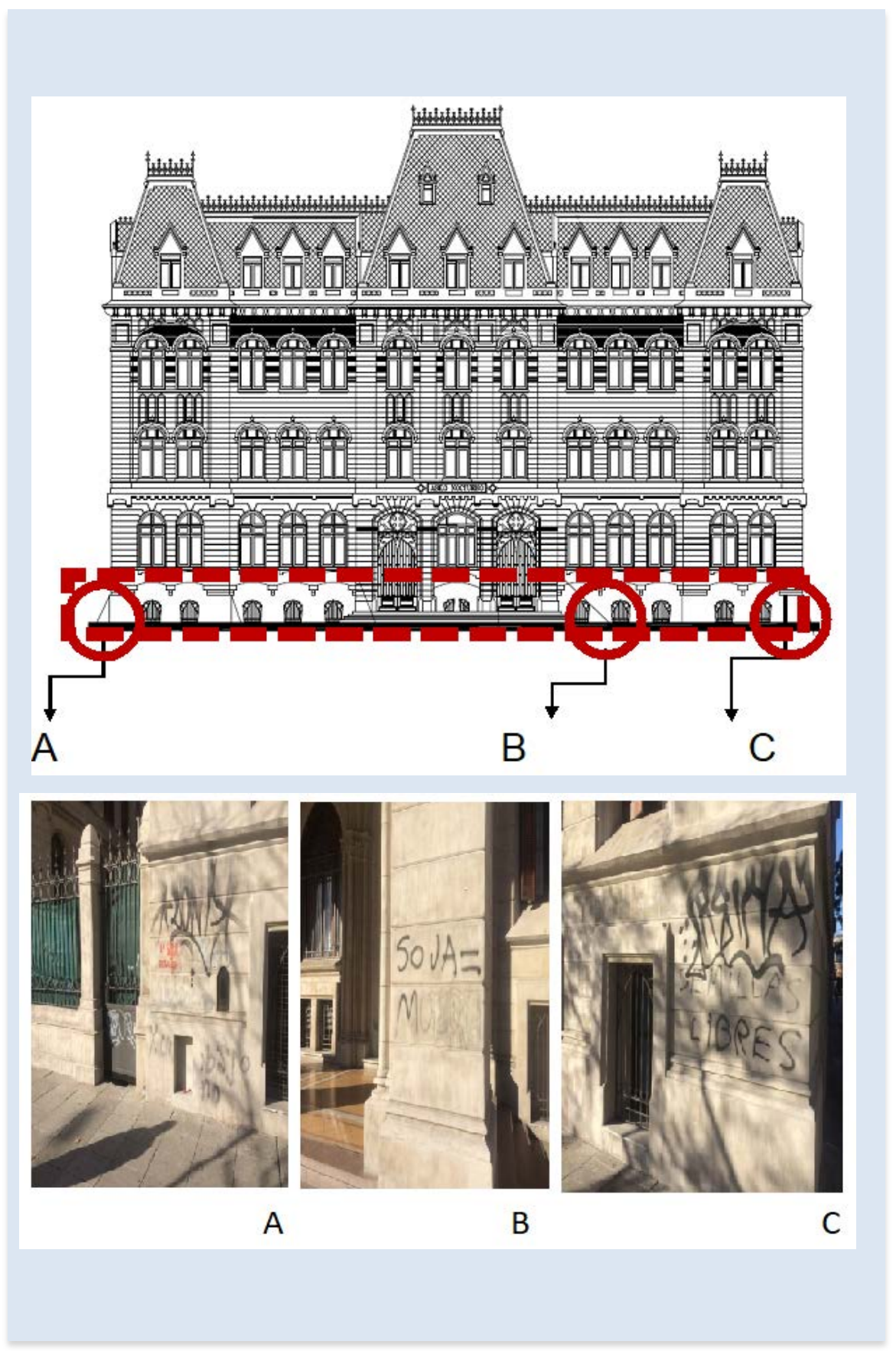

Fig. $N^{\circ}$ 61- Fachada Paseo Colon No982Plano Digitalizado por el CeDIAP.

Fig. $\quad N^{\circ} 62$ a $64 .-$ Fotografías de los sectores afectados por los grafitis. (Autoría Propia). 
El 22 de enero del año 2014 el arquitecto y consultor Marcelo Magadán es quien realiza el primer informe de los grafitis de la fachada de Paseo Colon $N^{\circ} 982$.

Esto es debido a que días previos a esa fecha, se produjo una manifestación sobre el acceso principal de la Avenida Paseo Colón. Como consecuencia de la misma se pintaron leyendas en la fachada de edificio, además de mancharlo ya que fueron arrojados algunos productos como, por ejemplo: tomates.

A diferencia de otras pintadas realizadas en el curso de un acto similar unos meses antes, estás no pudieron ser retiradas, lo que llevo a relevar los sectores afectados y hacer una serie de consultas acerca del desarrollo de los hechos, con las diferentes personas que estuvieron vinculadas a los posteriores intentos de limpieza.

De esta indagación queda en claro que, si bien se usó removedor en gel (Texxor), el mismo habría estado vencido. Esto explica porque el removedor aplicado no hizo efecto sobre las pintadas cuando fue aplicado por el personal de limpieza en la tarde de la misma jornada de la manifestación.

Días después se realizó otro intento de retiro de los grafitis, esta vez por personal de la contratista de la empresa Niro Construcciones, que resultó también fallido. En esta ocasión se usó el mismo removedor gel usado en el anterior evento de pintadas, proveniente de una lata comprada y abierta en el momento, pero tampoco se obtuvieron resultados satisfactorios.

Esto último tiene directa relación con el espesor final del antigrafiti aplicado. Es sabido que el producto aisla la superficie porosa del símil piedra del grafiti o del adhesivo (en caso de una pegatina), que se fijan a la superficie externa de la protección, manteniendo indemne al revestimiento. Pero para que esa protección sea eficaz la capa de antigrafiti debe ser suficientemente gruesa, es decir debe formar una película de un milímetro rellenando los bajo relieves de la textura, tal como lo muestra el siguiente gráfico. (Ver Fig. № 65).

Conjunto Edilicio Ministerio de Agroindustria de la Nación (ex Asilo Nocturno de la Capital) 
Fig. N66.- Detalle correcta colocación del antigrafiti (Gráfico perteneciente al informe realizado por el arquitecto Magadán el 22 de enero de 2014).

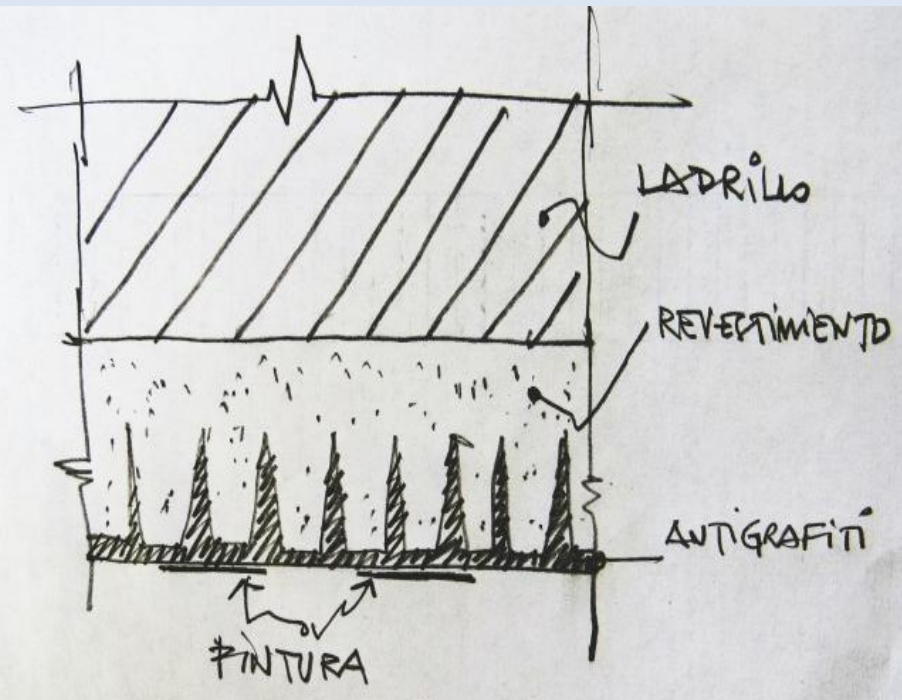

Por otro lado, y según se describió en el capítulo anterior, había entre las entonces autoridades del Ministerio la voluntad de instalar un nuevo sistema de iluminación exterior. Motivo por el cual, hacia principios del año 2014 se solicitó, un informe detallado al Arqto. Magadán.

Esta iniciativa todavía no fue atendida y constituye una falencia que colabora con que se continúen produciendo actos vandálicos. Los que podrían evitarse incorporando una iluminación eficaz y colocando cámaras de seguridad en ubicaciones estratégicas, amedrentando así a los violentos que siguen provocando daños en los paramentos de los edificios.

\section{Patologías de Humedades}

Se acude a realizar un relevamiento, en respuesta al llamado desde una de las oficinas ubicadas sobre la cara este del segundo piso del edificio mencionado, por problemas de humedad.

Así se detecta en varias oficinas contiguas una patología que se repite: humedad en muros, cielorrasos y techos. A partir de este registro se procede a analizar cada uno de los planos del proyecto original, tanto el de arquitectura, como el de instalaciones. 
Se comprueba que la localización de estos deterioros coincide con las bajadas de los desagües pluviales desde las terrazas del 4to piso hacia la Planta Baja. (Ver fig. № 67).

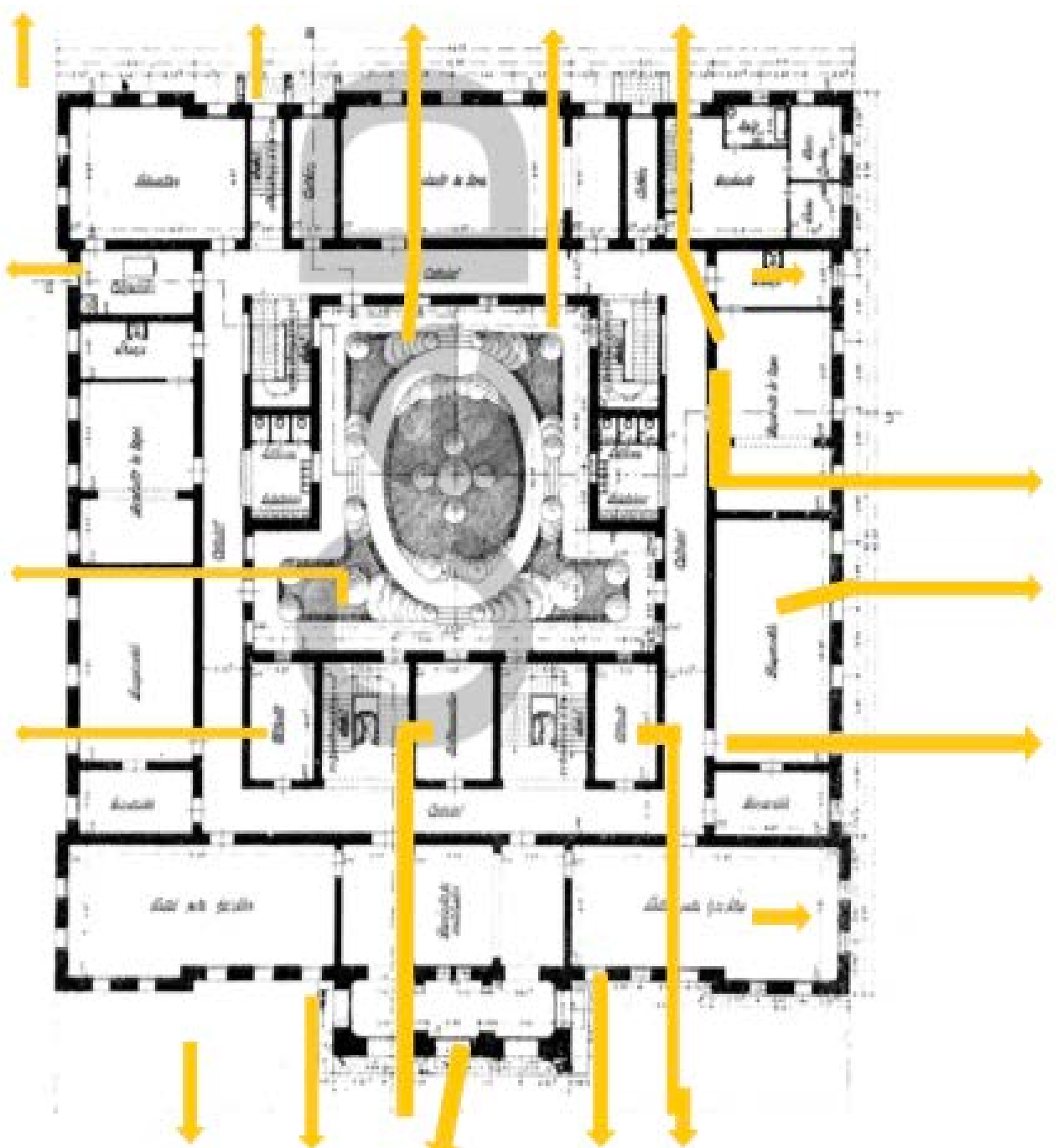

Fig. No 67.- Plano ubicación bajadas pluviales PB edificio Paseo Colon No 982 (Digitalizado por CeDIAP).

La oficina más afectada por la presencia de humedad y sales solubles que coincide con la bajada de uno de los desagües pluviales es la registrada con el $\mathrm{N}^{\circ} 220$, en el segundo piso del mencionado edificio. Posee además revoques desprendidos y un parche de cemento producto del retiro de un equipo de aire acondicionado tipo Split. (Ver Fig. N$^{\circ}$ 68 y 69). 
Dicha oficina posee actualmente un entrepiso utilizado como archivo y guardado de documentación que no figura en el proyecto original, sino que fue incorporado en una etapa posterior.

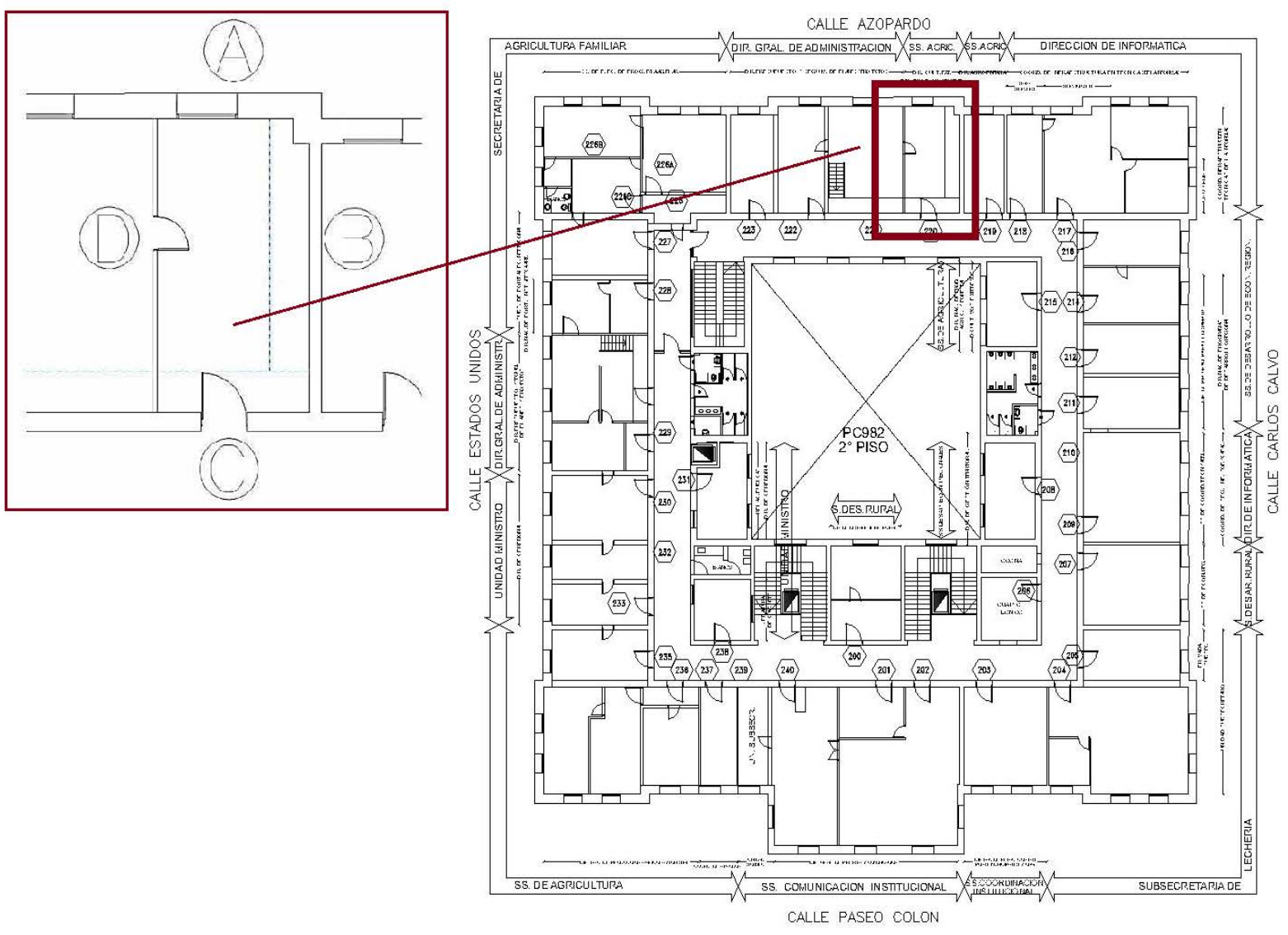

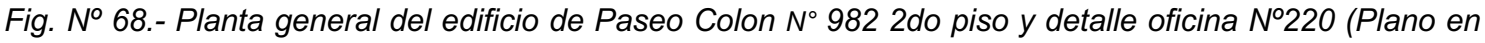
AutoCAD de autoría propia). 

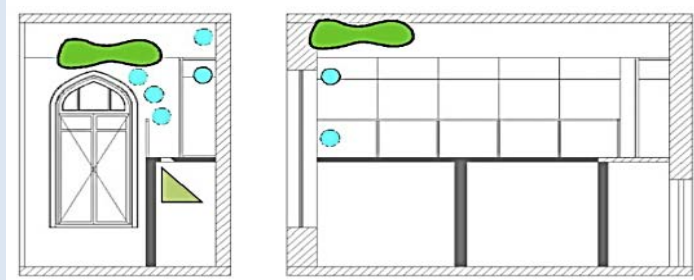

$\Delta$
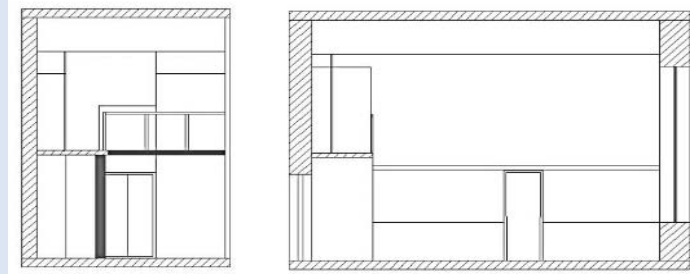

Referencias:

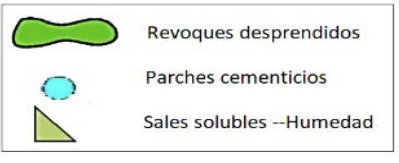

Fig. N69.- Cortes Detalle de la oficina N²20 correspondiente al 2 do piso de Paseo Colon N ${ }^{\circ} 982$.

(Plano en AutoCAD de autoría propia).

\subsubsection{Informe de seguridad de fachadas - (junio de 2019)}

Debido a que se registraron sucesivos desprendimientos de revoques y fisuras en los diferentes sectores de las fachadas de los pisos superiores de ambos volúmenes principales, las autoridades del área de la DTO del Ministerio de Agroindustria decidieron volver a contratar al Arqto. Asesor Marcelo Magadán para que realizara, junto a su equipo, un informe de seguridad de las fachadas, evaluando la magnitud de los deterioros y las medidas que debían tomarse en consecuencia.

Los relevamientos se realizaron entre los meses mayo y junio del año 2019, en diferentes jornadas laborales y horarios, abarcando los edificios de Paseo Colon № 982 y 922. Como herramienta de trabajo se utilizó un dron, para los sectores más altos, y cámara digital a modo de completamiento de aquellos sectores bajos o de difícil acceso para el equipo. Las tareas estuvieron dirigidas por la arquitecta M. Victoria Menendez. A partir de los resultados obtenidos del estado de situación, se presentó una propuesta de intervención. Dada la importancia y complejidad del caso se formularon diferentes alternativas y de aquellas opciones se desarrolló la documentación necesaria para la obra, a saber: pliego de especificaciones técnicas, fichas técnicas (materiales y maquinaria necesaria para el caso), planillas de cotización, cómputo y presupuesto. 
En el informe además se incorporaron planos del estado actual en donde se volcaron cada uno de los deterioros detectados en forma gráfica y estos fueron complementados con su respectivo relevamiento fotográfico.

En el siguiente cuadro se pueden observar los tipos de deterioros encontrados en las fachadas, esto es: en revoques, mamposterías y celosías, los cuales fueron referenciados en los planos presentados. (Ver Fig. $N^{\circ} 70$ y 71 ).

\section{CELOSÍA}

\begin{tabular}{|c|c|l|}
\hline & \multicolumn{1}{|l|}{} & $\begin{array}{l}\text { Interrupción de la continuidad de la estructura de } \\
\text { la madera, que afecta a la totalidad del espesor de } \\
\text { la parte o elemento. Según el caso, el fragmento } \\
\text { fracturado puede permanecer en su posición } \\
\text { original, adherido, o encontrarse desprendido y/o } \\
\text { desplazado. }\end{array}$ \\
\hline Desprendimiento tablilla & $\begin{array}{l}\text { Pérdida de vinculación entre la tablilla y la/s } \\
\text { montante/s. }\end{array}$ \\
\hline
\end{tabular}

\section{REVOQUE Y/O MAMPOSTERÍA}

\begin{tabular}{|r|r|l|}
\hline Desprendimiento de revoque & & $\begin{array}{l}\text { Pérdida de vinculación entre el revestimiento y el } \\
\text { soporte. }\end{array}$ \\
\hline Faltante de revoque & & $\begin{array}{l}\text { Mermas parciales o totales de los revestimientos } \\
\text { en las partes o elementos que componen las } \\
\text { diferentes fachadas. }\end{array}$ \\
\hline Fisura & $\begin{array}{l}\text { Interrupción de la continuidad de la estructura del } \\
\text { material, de carácter superficial. En consecuencia } \\
\text { no afecta a la totalidad del espesor de la parte o } \\
\text { elemento. } \\
\text { Se manifiestan en forma de hendidura con una } \\
\text { abertura de entre 0,5mm y 3mm. Se deben a } \\
\text { tensiones internas o externas generadas por } \\
\text { dilatación y contracción, etc. }\end{array}$ \\
\hline Fractura & $\begin{array}{l}\text { Interrupción de la continuidad de la estructura del } \\
\text { material, que afecta a la totalidad del espesor de } \\
\text { la parte o elemento. Según el caso, el fragmento } \\
\text { fracturado puede permanecer en su posición } \\
\text { original, adherido, o encontrarse desprendido y/o } \\
\text { desplazado. }\end{array}$ \\
\hline 5
\end{tabular}

Fig. $N^{\circ} 70$ y $N^{\circ} 71$.- Cuadros referencias de patologías encontradas en revoques y/o mampostería y en celosías. Confeccionados por el arqto Magadán y su equipo. Año 2019. 
Lo que se detalla a continuación son las conclusiones arribadas en el citado informe y entregados oportunamente a la DTO del Ministerio de Agroindustria.

\section{ESTADO DE SITUACIÓN}

Analizados los deterioros y potenciales peligros de ambos edificios, el equipo liderado por la arquitecta Menéndez, llegó a la conclusión de que los sectores con mayor cantidad de deterioros son los ubicados entre los siete (7) y los veintiseis (26) metros de altura. Las fisuras, en la tapa de cornisas son los casos más usuales, y las fracturas en los ángulos de las cornisas superiores las que presentan mayor gravedad y urgencia de intervención.

Otro de los factores a destacar son las celosías, con deterioros tales como desprendimiento de tablillas o fractura de parantes. Estos casos representan un potencial peligro por la caída de material o elementos de las propias celosías.

Esta situación condujo a pensar en la incorporación de un apartado con recomendaciones e indicaciones a compartir con el personal de las oficinas, apelando con su colaboración, hacia un correcto mantenimiento del bien.

El caso de las celosías, si bien se trata de una problemática a ser intervenida con inmediatez, no representa complejidad en el accionar dado que las que requieren ser tratadas se pueden retirar desde el interior. En cambio, los deterioros en mampostería y revoques son más complejos de resolver, por la ubicación - mayoritariamente- en altura, y por la cantidad al estar diseminados por las diferentes fachadas.

Se optó por plantear diferentes propuestas de trabajo: una de obra o intervención completa, y otra dividida en dos (2) etapas, pensando ante todo en la optimización de los esfuerzos económicos, de tiempos y tareas. Esto es intervenir todos los deterioros que representaban mayor riesgo primero y luego en la instancia siguiente, atacar los deterioros que no constituían a esa fecha, gravedad o urgencia.

Es por esta razón que se presentó la documentación necesaria para poder abordar la situación con dos propuestas que respondían de diferente forma a la problemática de accesibilidad de la fachada, recomendando la solución que se consideraba más beneficiosa para ser evaluada por las autoridades del Ministerio. 


\subsubsection{Problemática en terraza del 4to piso edificio Paseo Colon $N^{\circ} 982$ por} adiciones varias, superpoblación y limitaciones en la evacuación de personas en caso de siniestro.

Si bien todos y cada uno de los edificios que integran el conjunto han sufrido a lo largo de los años modificaciones en relación al proyecto original como adiciones de volúmenes y subdivisión de oficinas, en este caso se opta por analizar que resoluciones deben tomarse puntualmente en el área que involucra al 4to Piso de Paseo Colón $\mathrm{N}^{\circ} 982$.

Alí nos encontramos frente a una realidad particularmente compleja con áreas de trabajo superpobladas y carentes de medios de escape seguros ante una situación imprevista que exija una rápida evacuación desde ese nivel hacia la planta baja.

Descripción:

La planta del cuarto piso originalmente constituía la terraza accesible a la cual se podía llegar por medio de una escalera caracol ubicada sobre su cara oeste, dentro de la torreta principal, según se observa en distintos cortes. (Ver Fig.N72).

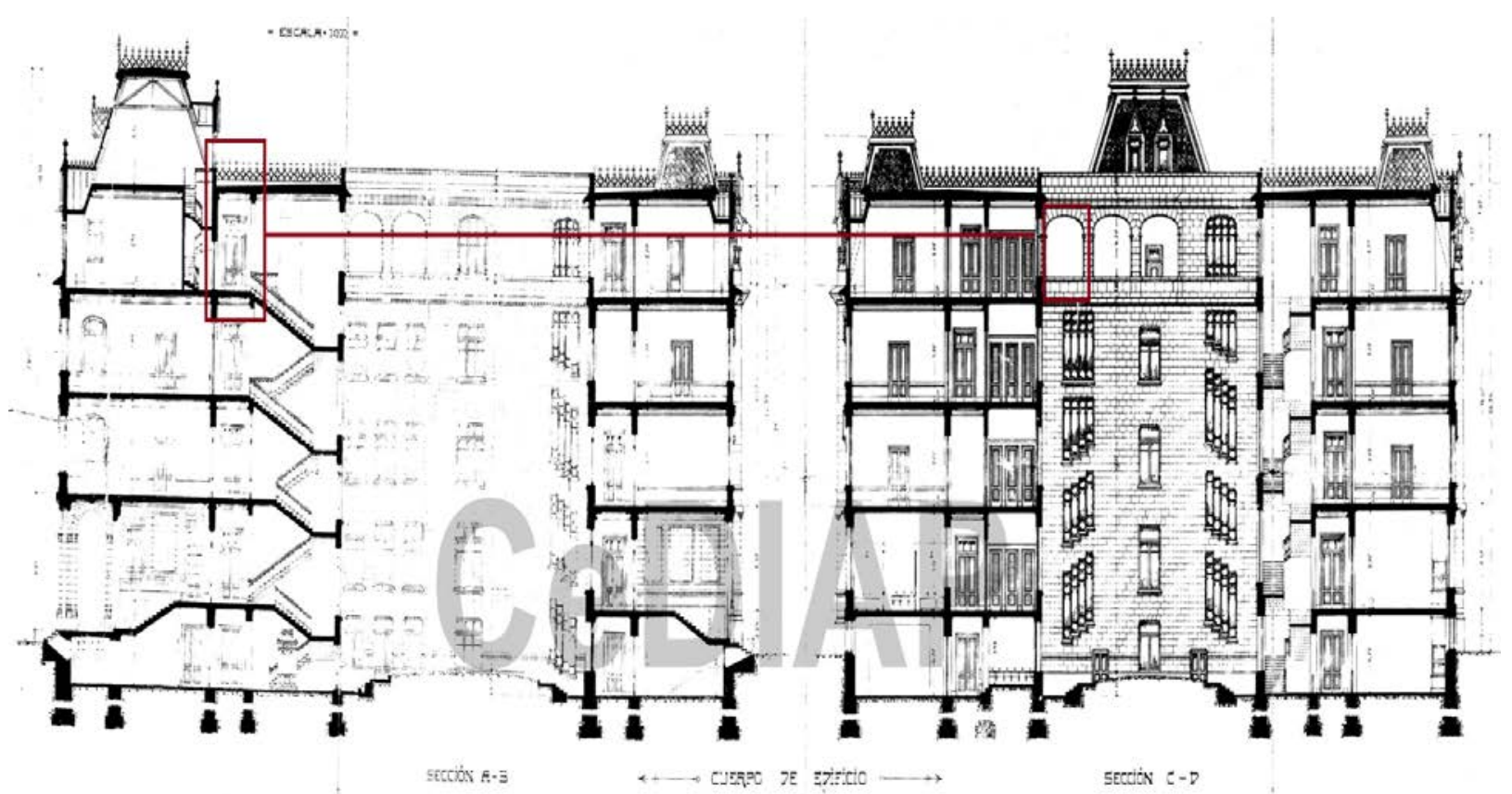

Fig. N72- Cortes (A-B y C-D) del edificio de Paseo Colon N982. Año 1911, digitalizado por el CeDIAP. 
En intervenciones posteriores se fueron adicionando locales para distintos usos como por ejemplo: consultorios médicos, además de sanitarios y un ascensor pequeño con capacidad de hasta tres (3) personas. Dicha ampliación aparece en planos que datan del año 1936 y a continuación se muestra la situación actual. (Ver Fig.N 73 y № 74).

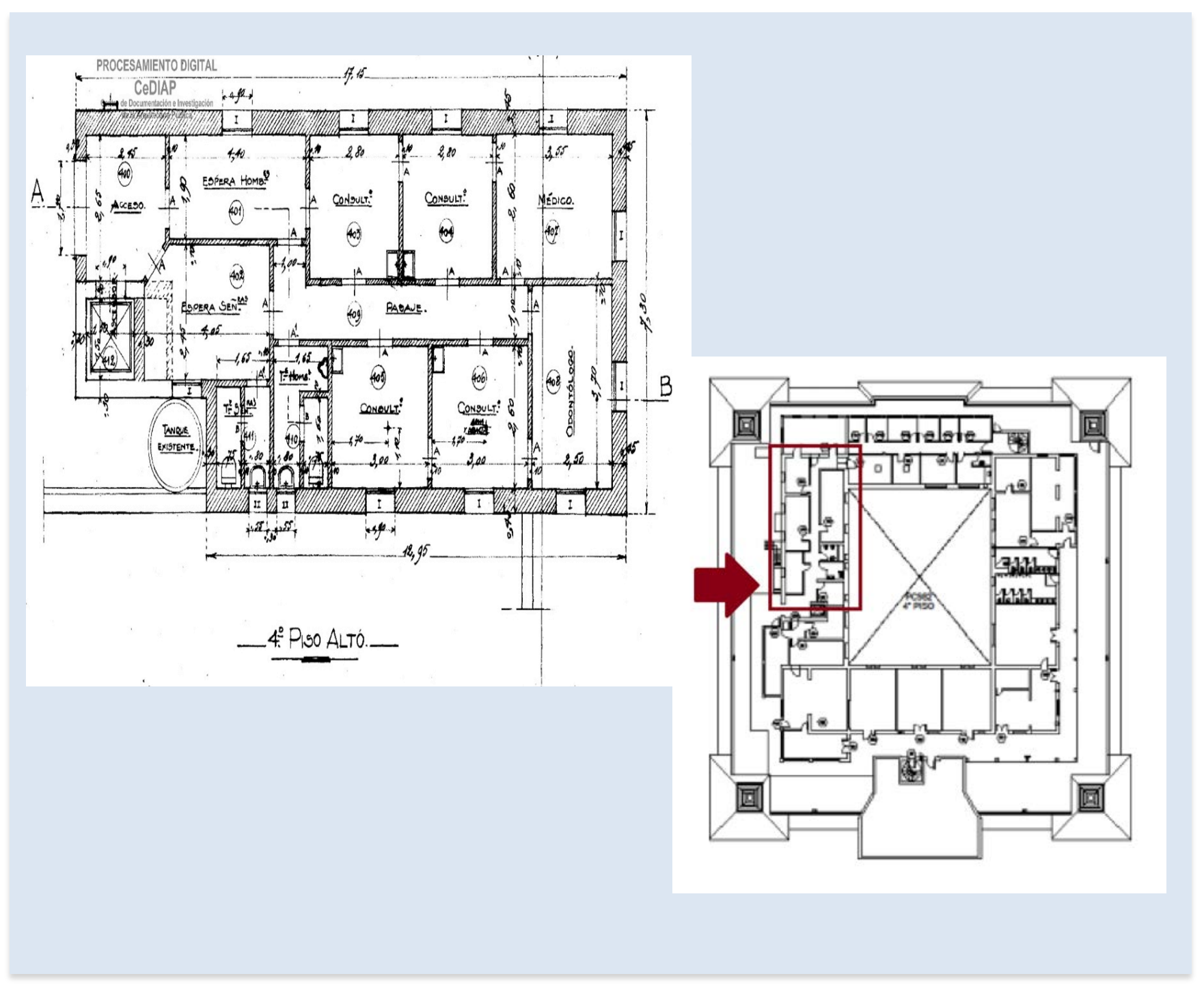

Fig. $N^{\circ} 73$ y No 74.- Planta Ampliación sector NE del 4to piso del edificio de Paseo Colon $N^{\circ} 982$ (Plano año 1936, digitalizado por el CeDIAP) y Planta actual (Autoría propia).

Otras adiciones como espacios de oficinas, parrillas y escaleras se fueron incorporando paulatinamente hasta ocupar hoy el $100 \%$ de la planta, dejando libre solamente un área de circulación perimetral (ver Fig. $N^{0} 75$ y $\mathrm{N}^{\circ} 76$ ). 
FACULTAD DE ARQUITECTURA Y URBANISMO - UNIVERSIDAD NACIONAL DE LA PLATA MAESTRÍA EN CONSERVACIÓN, RESTAURACIÓN E INTERVENCIÓN DEL PATRIMONIO ARQUITECTÓNICO Y URBANO (CRIP - FAU / UNLP)

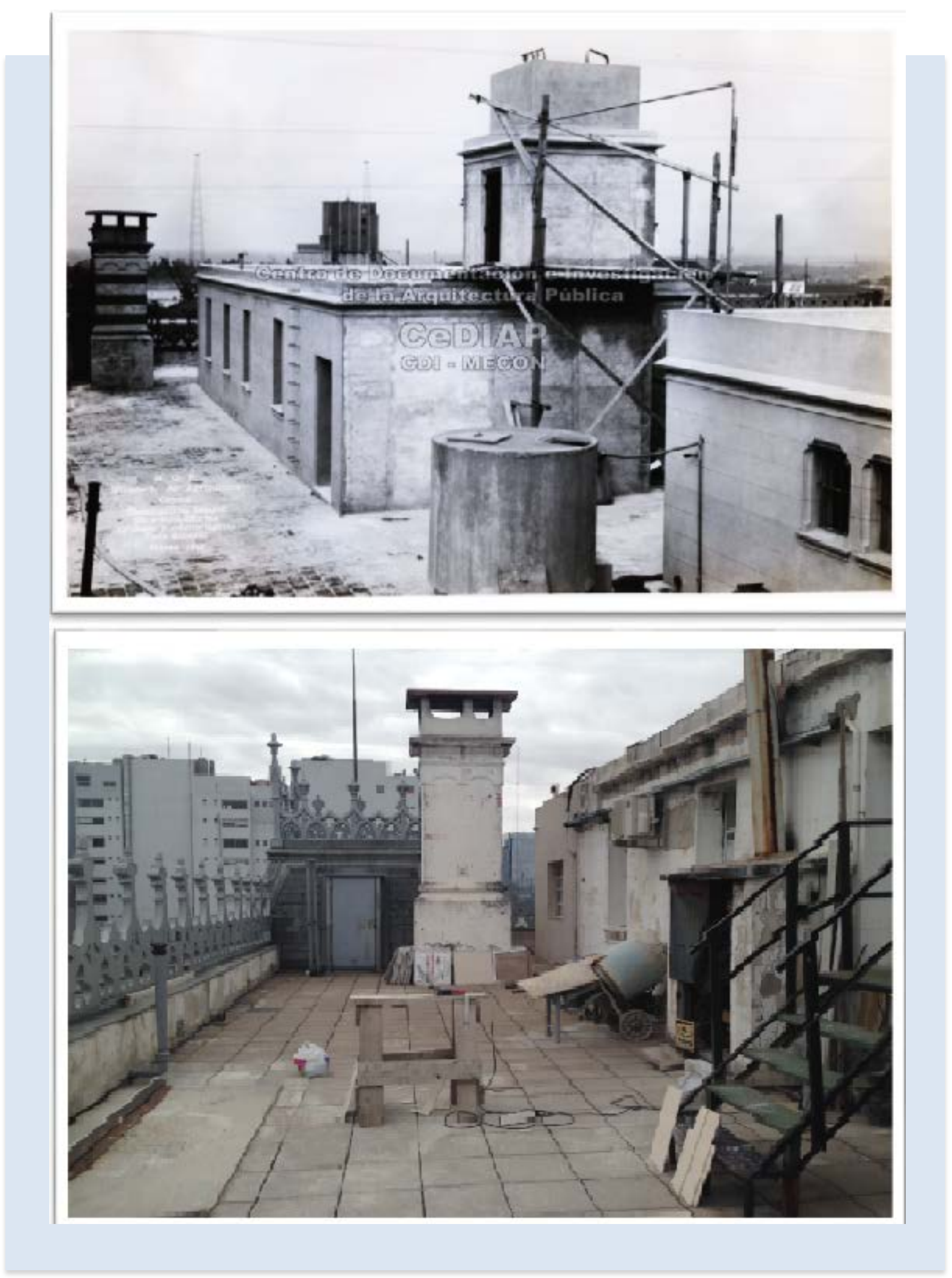

Fig. $N^{\circ} 75$ y N ${ }^{\circ}$ 76.- Fotografía Antigua Ampliación sector NE del 4to piso del edificio de Paseo Colon $N^{\circ}$ 982 (Circa 1936, digitalizado por el CeDIAP) y actual del mismo sector (Autoria Propia). 
Estimando que actualmente en ese nivel, alrededor de cuarenta y cinco (45) personas se encuentran trabajando en las distintas oficinas, la terraza representa un alto riesgo en caso de ser necesaria una inmediata evacuación. Esto es debido a que las circulaciones principales tienen su última parada en el tercer piso y los medios de salida habilitados además de ser antireglamentarios, resultan insuficientes para la rápida desocupación del piso en relación a esa cantidad de personal.

\subsubsection{Conclusiones parciales}

Las patologías encontradas refieren a una problemática compleja que contempla varios subsistemas y requieren un abordaje integral.

No basta solamente con atacar los deterioros encontrados, sino que además se hace necesario establecer una secuencia de trabajo que apunte a detener y revertir los daños elaborando un plan de mantenimiento preventivo para que no se repitan a futuro.

En cuanto a las deficiencias relacionadas a aspectos de funcionalidad, se deberá evaluar una metodología que aporte soluciones técnicas y permita rediseñar las áreas comprometidas, para liberar a los edificios de toda volumetría no original, lograr la recuperación de estos espacios y darles un uso eficaz, acorde a los nuevos requerimientos. Pero fundamentalmente volviéndolos piezas arquitectónicas seguras que cumplan con todos los estandares y reglamentaciones vigentes.

\subsection{Planteo de Soluciones a las Situaciones encontradas}

A continuación, se incorpora una grilla que tiene por fin enunciar sintéticamente los problemas y oportunidades del conjunto edilicio. Esto según los relevamientos realizados y el informe de fachadas presentado. Las conclusiones a las cuales se ha arribado son las que permiten establecer las estrategias de intervención que se proponen implementar. Las que serán desarrolladas en detalle seguidamente. (Ver Fig. $\left.\mathrm{N}^{\circ} 77\right)$.

Conjunto Edilicio Ministerio de Agroindustria de la Nación (ex Asilo Nocturno de la Capital) 


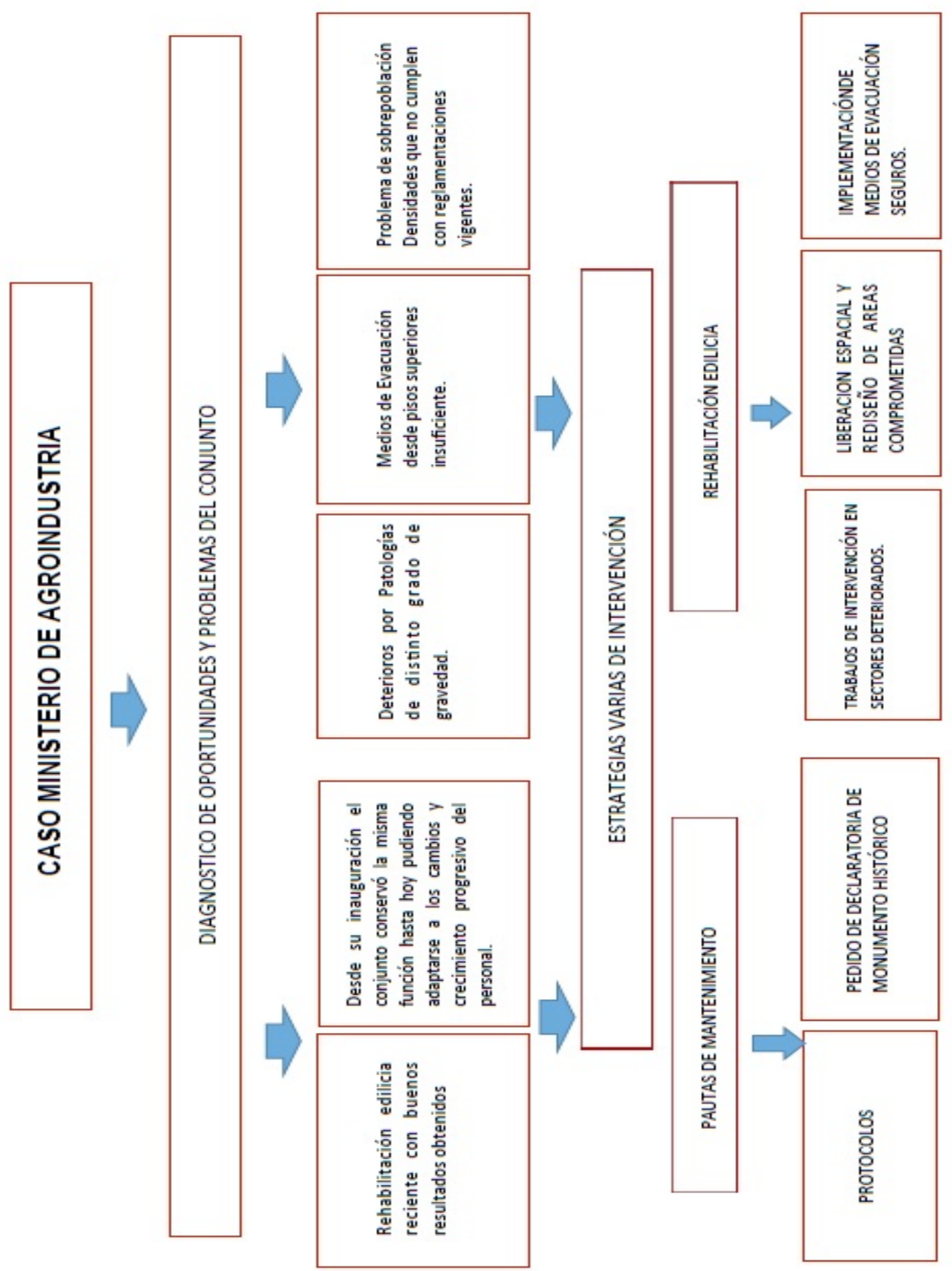

Fig. $N^{\circ}$ 77.- Grilla Problemas, oportunidades y estrategias de intervención del conjunto edilicio (autoria propia). 


\subsubsection{Trabajos de Intervención edilicia}

Rehabilitación Edilicia: En cuanto al Pto 4.1.1. referido a las patologías encontradas en elementos constructivos se deberá seguir el siguiente criterio:

> Para retirar grafitis aplicar removedor en gel al agua (en el edificio ya se hicieron trabajos previos, logrando buenos resultados con la utilización del producto de marca VITECSO).

El mismo debe aplicarse con pinceles de entre 4 y $6 \mathrm{~cm}$ de ancho y dejarlo actuar hasta unos 15 minutos. El tiempo de contacto dependerá de una serie de factores a tener en cuenta por el operador: temperatura ambiente, exposición al sol, viento, tipo de pintura a remover, etc. Es posible que haya que repetir el proceso más de una vez.

El gel solo se retira con agua a presión controlada impulsada por una hidro lavadora. La lanza debe tener un chorro espátula. La presión se controla básicamente regulando la distancia de la lanza al muro. El exceso de esta deteriora irreversiblemente el revestimiento.

Bajo ningún concepto deben usarse elementos abrasivos o punzantes (cepillos de alambre, espátulas, lijas, piedras de amolar, etc.) ya que dañan la superficie. En el caso que los grafitis se encuentren sobre elementos metálicos (portones, tapas, rejas, etc.) o de madera (ventanas), se evaluará si es necesario removerlos o si conviene lijar la superficie y repintarla con esmalte sintético (previa aplicación de anti óxido, si se requiriera esa protección) para el metal o láser para la madera.

Los operadores tendrán el equipo de protección requerido para desarrollar estas tareas. Deberán recibir el entrenamiento previo. Las operaciones de remoción de grafitis estarán supervisadas siempre por personal técnico.

Paso siguiente se colocará un antigrafiti: Los edificios poseen un recubrimiento de antigrafiti a la cera en todo el perímetro de cada uno de los basamentos y hasta una altura de $2.40 \mathrm{mts}$.

Actualmente estos basamentos presentan sectores con grafitis y otros en los cuales ese recubrimiento se encuentra degradado y requiere ser aplicado nuevamente. 
Por ello hay que realizar dos operaciones; primero en los sectores de fachada no afectadas por grafitis, hay que lavar cuidadosamente la superficie con agua a presión controlada, empleando exclusivamente una hidro lavadora.

En las zonas adonde deben removerse grafitis, junto con estos se quitará también el producto antigrafiti. En todos los casos hay que dejar secar los muros. Luego con las superficies limpias, secas y libres de todo polvo, se deberá proceder a aplicar el antigrafiti nuevo.

Se procurará utilizar el mismo producto sacrificable a la cera que se empleó anteriormente, durante las intervenciones a los edificios según consta en los manuales de mantenimiento de las empresas.

La aplicación deberá hacerse con pinceles de entre 4 y $6 \mathrm{~cm}$, de tal modo que logre formar una película de protección sobre el revestimiento, para lo cual se deberán dar tantas manos como sea necesario hasta lograrlo.

Dependiendo de la época del año en que se aplique será la consistencia que tenga. En invierno se logrará la película con pocas manos, pudiendo ser necesario calentar el bidón a baño maría para poder manipular el producto. En verano, por el contrario, para formar la película deseada deberán repetirse más manos.

Los operarios deberán contar con equipo de protección integrado por guantes de nitrilo y protector ocular, además de elementos para cubrir el entorno: cinta de enmascarar, polietileno, etc. y tener los cuidados del caso.

Es importante aclarar que se detectaron varias ocasiones en las cuales frente a la aparición de grafitis con textos inapropiados se envió a personal de mantenimiento de la DTO a retirarlos.

En estos casos siempre primaba el apuro por quitar los grafitis por encima del método a utilizar para el retiro de los mismos. Por ello, en estas situaciones puntuales que se detallan, se usaron materiales abrasivos como esponjas de acero para raspar las superficies en forma rápida hasta eliminar los grafitis sin importar si el procedimiento provocaba la degradación del revestimiento simil piedra. 
Se realizaban los trabajos sin consultar al personal especializado en estos temas y en horarios nocturnos siendo detectados al día siguiente cuando el resultado era irreversible.

$>$ En cuanto a las patologías de humedad en muros los procedimientos que se deberán realizar son los siguientes:

En la cara exterior: Se comenzará verificando el estado de cada una de las canaletas de desagües pluviales que se encuentran en la azotea del 4to piso por encima de la oficina afectada.

Luego se limpiarán aquellas que se encuentren obstruidas por: suciedad, hojas de árboles, restos de materiales de intervenciones anteriores, etc.

Se instalará una rejilla (red flexible) destinada a cubrir la parte superior de la bajada de la canaleta para impedir el ingreso de elementos que obstruyan el libre escurrimiento del agua de lluvia.

Dado que además de hojas, ramas y escombros, las canaletas suelen tener en su interior residuos de tierra, para limpiarlos, se instalará un pistón a presión en la manguera.

Se recogerán manualmente las hojas y otros objetos que obstaculicen el desplazamiento del agua. Se barrerá y retirarán los restos de suciedad acumulada al interior de estas, cuidando de no empujar los escombros hacia el interior de las bajadas, enjuagándolas con chorro a presión de la manguera hasta dejarlas bien limpias.

Luego se continuará con las bajadas. Para limpiarlas por dentro, se insertará en ellas la manguera y abrirá el flujo del agua a máxima presión para arrastrar todas las hojas acumuladas.

Una vez terminada la limpieza, se inspeccionarán detenidamente las canaletas y bajadas para evaluar posibles filtraciones, zonas perforadas o rotas. Si se detectan problemas, se realizarán las reparaciones necesarias o cambiará el tramo con desperfecto. Para corregir daños menores como agujeros o roturas pequeñas se usará silicona neutra transparente.

Se soldarán o unirán aquellos sectores que se encuentren sueltos. En el caso de roturas mayores, se procederá a repararlas utilizando resina mezclada con un polímero fijador (Reactivo) al $2 \%$. Se aplicará embebiendo con pincel trozos pequeños de fibra de vidrio 
en tela (de 1 1 $1 / 2$ ) cubriendo los sectores afectados. Una vez seco, se lijará para darle terminación.

Aclaración: Cuando se trabaje en los edificios anexos, que poseen alturas menores (correspondientes a la actual Dirección Nacional Foresto industrial y el área de Pesca) si hay algún árbol creciendo cerca de estos, se deberá podar y despejar la zona para reducir la cantidad de hojas y ramas que puedan caer dentro de las canaletas.

Procedimientos que se deberán realizar en la cara Interior:

Se picará todo el paramento afectado lindante con el jardín interior y la esquina límite con el entrepiso existente para lo cual será preciso previamente vaciar los muebles y retirar la documentación existente en su interior para su resguardo.

Se les dará una protección antihumedad a los muros, dejándolos secar por varios días, antes de continuar las tareas previstas.

Pasadas algunas semanas se constatará que el problema haya sido resuelto, observando detenidamente el sector, especialmente en días de lluvia.

Con los muros totalmente secos, se revocarán nuevamente y se los pintará acorde al color preexistente de la oficina.

Se relevará el mobilario dañado que por ser histórico requerirá ser restaurado por un carpintero especializado.

En cuanto al Pto 4.1.2. referido al informe de seguridad de fachadas entre los puntos más importantes de la propuesta de intervención cabe mencionar lo siguiente:

> ALTERNATIVAS DE TRABAJO Debido a que la mayoría de los deterioros, según lo anteriormente detallado, se ubican en los sectores bajo azotea hasta la cornisa inferior, es decir entre los 26 y los $7 \mathrm{~m}$ de altura, se evaluó- en una primera instancia- la posibilidad de resolver la intervención mediante el empleo de silletas.

Luego y analizando las particularidades de los edificios, se detectaron varios inconvenientes que complicarían las tareas bajo esta modalidad. Sobre todo, en relación a la dificultad en la salvaguarda de los componentes de la crestería que conforma el remate de las mansardas y además que las sogas a utilizar representan un riesgo 
concreto de deterioro de las superficies sobre las que apoyan y rozan, tal el caso de la mencionada crestería, pero también de los bordes externos de las cornisas.

Se deberían usar protecciones, pero se advierte que no son fáciles de colocar y además resulta dificultoso contar con elementos seguros que impidan la caída libre.

Se suma a lo anterior, la imposibilidad de acceder a todos los sectores, por lo que se debería complementar con el uso de andamios en aquellas zonas donde no es posible llegar con la silleta, tales como los volúmenes salientes de los extremos de los edificios, donde se encuentran algunos de los deterioros de mayor riesgo y que requieren de una intervención más compleja.

Por lo expuesto y descartando el empleo de silleta, se optó por evaluar el uso de andamios para atender a la totalidad de los daños encontrados. Al analizar el uso y costo de este sistema se detectaron algunas cuestiones negativas a tener en cuenta, entre las que se destacan que el tiempo de armado y desarmado de andamios extiende notablemente el plazo de obra, que termina por resultar excesivo. Por otro lado, para amortizar el costo de los mismos (que es elevado) se debe disponer de mayor cantidad de personal, de manera tal que pueda cubrir simultáneamente varias áreas de trabajo, en una misma fachada.

El montaje de andamios en el interior del predio traerá dificultades para el normal funcionamiento del organismo y en el exterior expone su seguridad, ya que los andamios en las aceras representan una posibilidad de que los mismos sean escalados provocando la intrusión a los locales que dan a la calle, a través de sus ventanas.

Como tercera opción se analizó la posibilidad de alquilar plataformas de elevación para trabajar en la franja de mayor altura (entre los 7 y los $26 \mathrm{~m}$ ) complementado con el uso de andamios para los sectores bajos (hasta $7 \mathrm{~m}$ ). Esta opción también presenta varias dificultades en cuanto al entorpecimiento de las labores de la plataforma, por interferencia con la ubicación de los andamios lo que implicaría un desaprovechamiento de este recurso más costoso y práctico.

Conjunto Edilicio Ministerio de Agroindustria de la Nación (ex Asilo Nocturno de la Capital) 
Por último, se optó por evaluar el alquiler de dos equipos diferentes: una pluma telescópica articulada capaz de llegar hasta los $26 \mathrm{~m}$ de altura; y una tijera de elevación de menor capacidad, que puede trabajar hasta los $7 \mathrm{~m}$.

Esta alternativa de combinación de equipos además de tener el menor costo de alquiler, permitirá obtener los mejores resultados por cuanto habilita el acceso a todos los sitios deteriorados y la llegada del personal de Inspección de Obra a todos los sectores requeridos.

Permite la optimización de los tiempos y las tareas ya que pueden trabajar varios sectores en una misma jornada laboral sin "tiempo muerto". Además, se minimizan las interferencias respecto del normal funcionamiento de los edificios y se anulan las posibilidades de intrusión a los mismos al no recurrir a los andamios.

Por las razones mencionadas previamente se sugiere la utilización de dos (2) plataformas de elevación, dedicadas cada una a sectores preestablecidos de las fachadas. En función de esto se desarrolló una variante del pliego de especificaciones técnicas para el caso puntual.

\section{RECOMENDACIONES PARA LOS USUARIOS}

Se optó por preparar una serie de sugerencias dirigidas a los usuarios de las oficinas/ locales respecto al uso de las celosías.

Entre ellas se destacan las siguientes acciones: ante todo que la totalidad de las celosías posean retenes y procurar cerrarlas al desocupar las oficinas, especialmente los fines de semana, feriados o días en los que no concurrirá personal, manteniéndose alerta en caso de tormentas o vientos fuertes.

También se vierten en el informe las recomendaciones respecto a la correcta apertura de las celosías, de modo que las hojas laterales queden en contacto con el espesor del muro y se puedan sujetar con sus correspondientes ganchos de retención. De esta manera, se asegurará que las cuatro (4) hojas no golpeen contra la fachada, todo esto acompañado de los esquemas gráficos explicativos. 
La segunda parte del informe corresponde al PET (Pliego de especificaciones técnicas).

El mismos está dividido en dos:

La primera parte que refiere al desarrollo de las tareas a realizar con plataformas de elevación (A1) y la segunda con andamios (A2). (Ver Fig. №78).

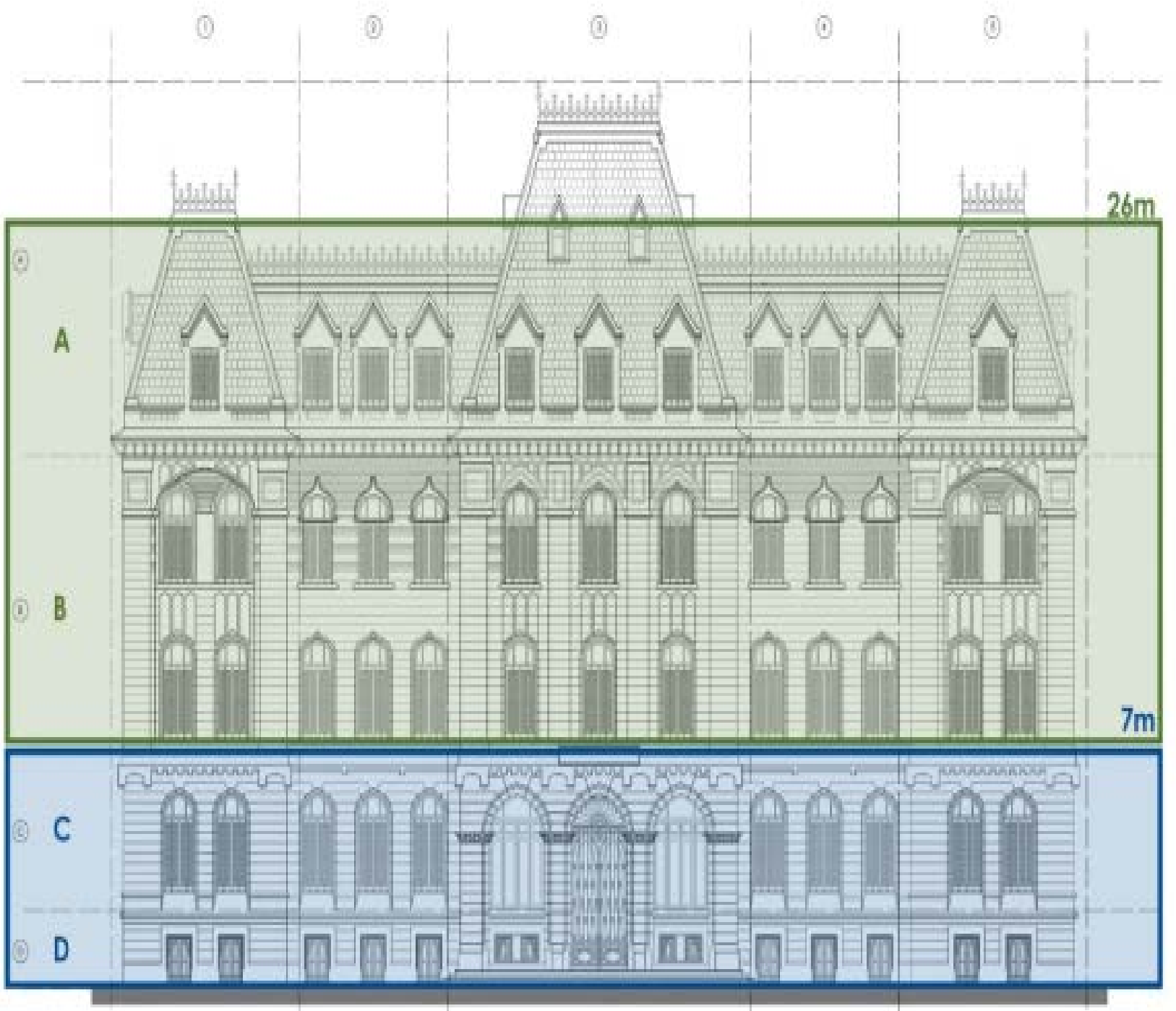

Fig. No 78- Esquema del desarrollo de las tareas con Plataformas de elevación (A1) y con andamios (A2 $\left.{ }^{35}\right)$. Plano elaborado por el arqto Magadán y equipo.

Resumiendo, el contenido del PET se detallan a continuación los puntos más sobresalientes:

${ }^{35}$ Presentado en el TOMO I del informe de seguridad de fachadas-Arqto Magadan- Año 2019.

Conjunto Edilicio Ministerio de Agroindustria de la Nación (ex Asilo Nocturno de la Capital) "Desarrollo de los instrumentos para la Conservación e Intervención del Patrimonio Arquitectónico. Hacia un Plan de Gestión". 


\section{(A1) PLATAFORMAS DE ELEVACIÓN}

Serán utilizadas para los trabajos en altura debiendo permitir un acceso fácil y seguro a cualquier parte o sector a ser intervenido. Las canastillas de las plataformas trabajarán con hasta dos (2) operarios por vez, los cuales deberán contar con los todos los elementos de Protección Personal (EPP) y mantenerse libres de escombros, basura, herramientas u otros elementos que no sean imprescindibles para la tarea a desarrollar.

Tendrán una protección fijada a la cara de arrime a la fachada, destinada a evitar la caída libre de escombros, materiales, etc. La pantalla se realizará a partir de un bastidor metálico que se habrá de sujetar a la baranda, recubierto con una red de seguridad y una tela media sombra al $80 \%$, colocada en doble capa. Red y media sombra deben quedar perfectamente sujetas a la estructura del mismo.

Dado el considerable peso de las maquinarias, éstas deberán trasladarse sobre planchas metálicas, con rigidez suficiente como para asegurar una adecuada repartición de las cargas sobre los pisos en que se trasladen y/o apoyen.

Se deberá prohibir el paso de peatones por debajo de la extensión del brazo de la maquinaria, así como por debajo de la canastilla, por lo que es imperante contar con un cerco de seguridad.

EI PET también hace mención sobre las protecciones, el pañol y los baños químicos que deberá proveer la contratista.

(A2) ANDAMIOS:

Para los trabajos en los pisos inferiores se sugiere la utilización de andamios de tipo tubular (pre-armados, de caño y nudo o sistema multidireccional) con piso operativo de tablones de chapa doblada antideslizante, el cual se deberá mantener libre de escombros, basura, herramientas u otros elementos que no sean imprescindibles para la tarea a desarrollar. 
Los andamios estarán dotados de escalera de servicio, con tramos con peldaños y sus correspondientes barandas. Los módulos que contendrán las escaleras deben estar colocados por fuera de los módulos de trabajo, es decir aquellos que estarán en relación directa con los sectores a intervenir.

Sus caras externas estarán totalmente revestidas con una cobertura vertical de tela media sombra al $80 \%$ que se tomará al andamio mediante precintos plásticos. La altura de colocación de la cobertura dependerá de la situación de la fachada.

Cuando se trate de una fachada que dé sobre la vía pública y en los sectores donde se ubiquen los pasadizos peatonales de acceso al Ministerio desde las calles interiores, la cobertura abarcará desde la pantalla que cubra el pasadizo, hasta el remate del andamio.

Dichas pantallas serán realizadas con tableros fenólicos, fijados a una estructura de madera (tirantes) tomada a los parantes del andamio. Se emplearán tableros limpios y sanos, colocados a tope, no admitiéndose superposiciones y estarán prolijamente pintados, de acuerdo al color que indique oportunamente la D.O.

La parte inferior del andamio (pasadizos) deberán contar con las medidas de protección requeridas: señalizaciones, iluminación nocturna, etc.

En los andamios que dan sobre los espacios interiores de la manzana que ocupan los edificios a intervenir, la cobertura abarcará la totalidad de su altura, desde el piso donde apoye, hasta el extremo superior de la estructura.

En el montaje del andamio se tendrá cuidado de no afectar los paramentos y salvaguardar al personal del organismo y al público en general. En cuanto a los trabajos en general refieren a las patologías a tratar según se enuncia en la siguiente grilla. (Ver Fig. $N^{0}$ 79). Lo referido al 4to Piso será detallado a continuación. 


\section{CASO MINISTERIO DE AGROINDUSTRIA}
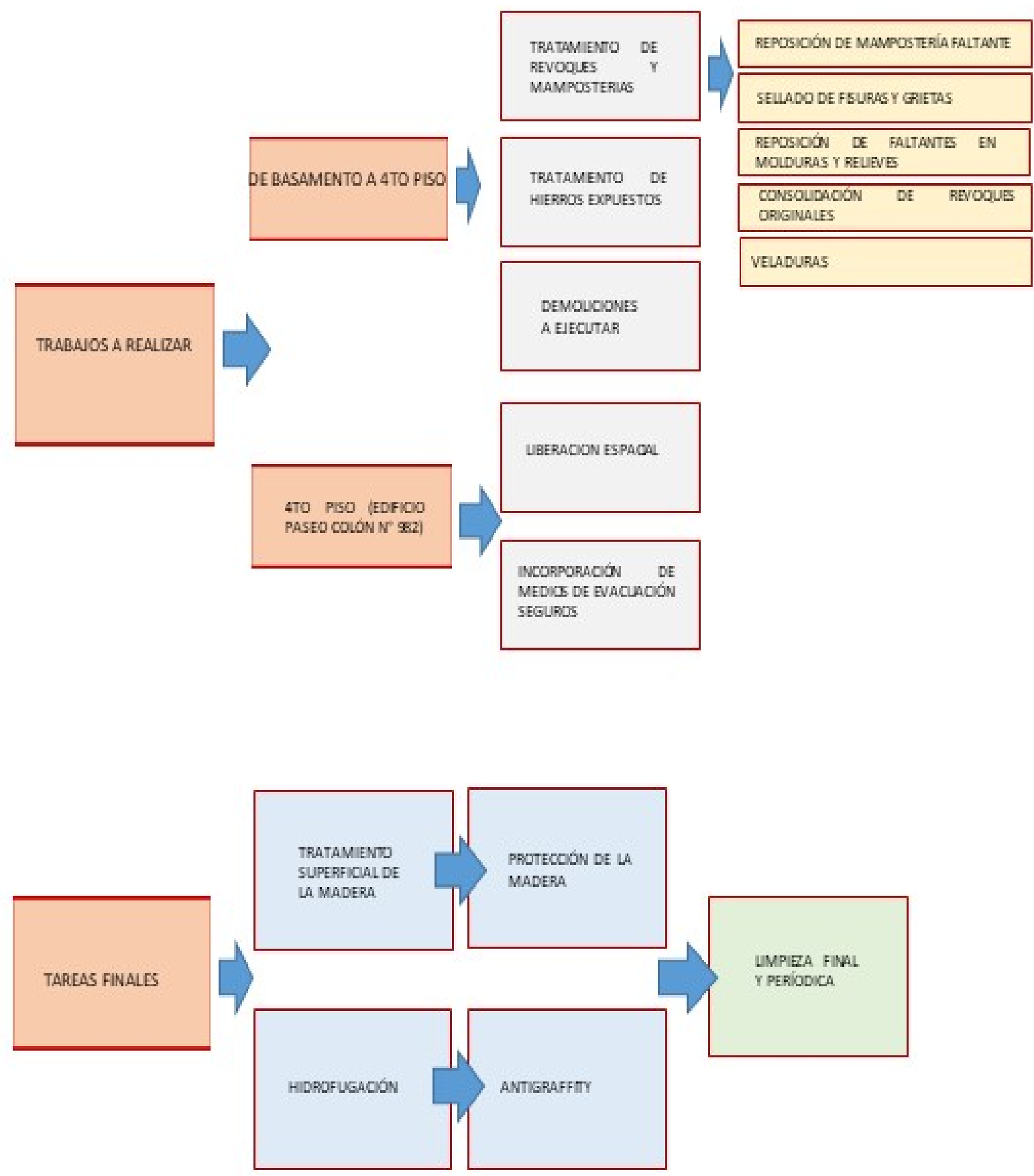

Fig. N 79.- Grilla Descripción de los Trabajos a realizar (Autoría Propia). 
En cuanto a las deficiencias encontradas en el 4to piso, por todo lo expuesto se sugiere:

1.- Liberación espacial Abarca el vaciamiento de todos los espacios anexados en distintas intervenciones y demolición de sus estructuras portantes. Solo se conservarán los locales destinados a: sanitarios, sala de máquinas del ascensor y las oficinas ubicadas en el extremo noreste, que fueron construidas como consultorios médicos en la primera etapa de ampliación del año 1936. Luego se propone la ejecución de un proyecto integral para incorporar un sector de expansión a ser utilizado por los empleados del Ministerio que generará múltiples beneficios socio-ambientales.

2.- Incorporación de medios de evacuación seguros La propuesta comprende las modificaciones a realizar para mejorar los medios de salida del 4to piso, hacia el nivel de planta baja. Según se mencionó anteriormente en la actualidad hay cerca de cuarenta y cinco (45) empleados que, en forma diaria cumplen sus tareas laborales en en alguna de las veinte (20) oficinas que conforman el perímetro de la terraza. Siendo los únicos medios de circulación vertical un ascensor de pequeño tamaño con capacidad para un máximo de tres (3) personas y una escalera tipo caracol ubicada sobre la cara oeste que une ese piso con el nivel inferior. (Ver Fig. $\mathrm{N}^{\circ} 80$ y 81 ).

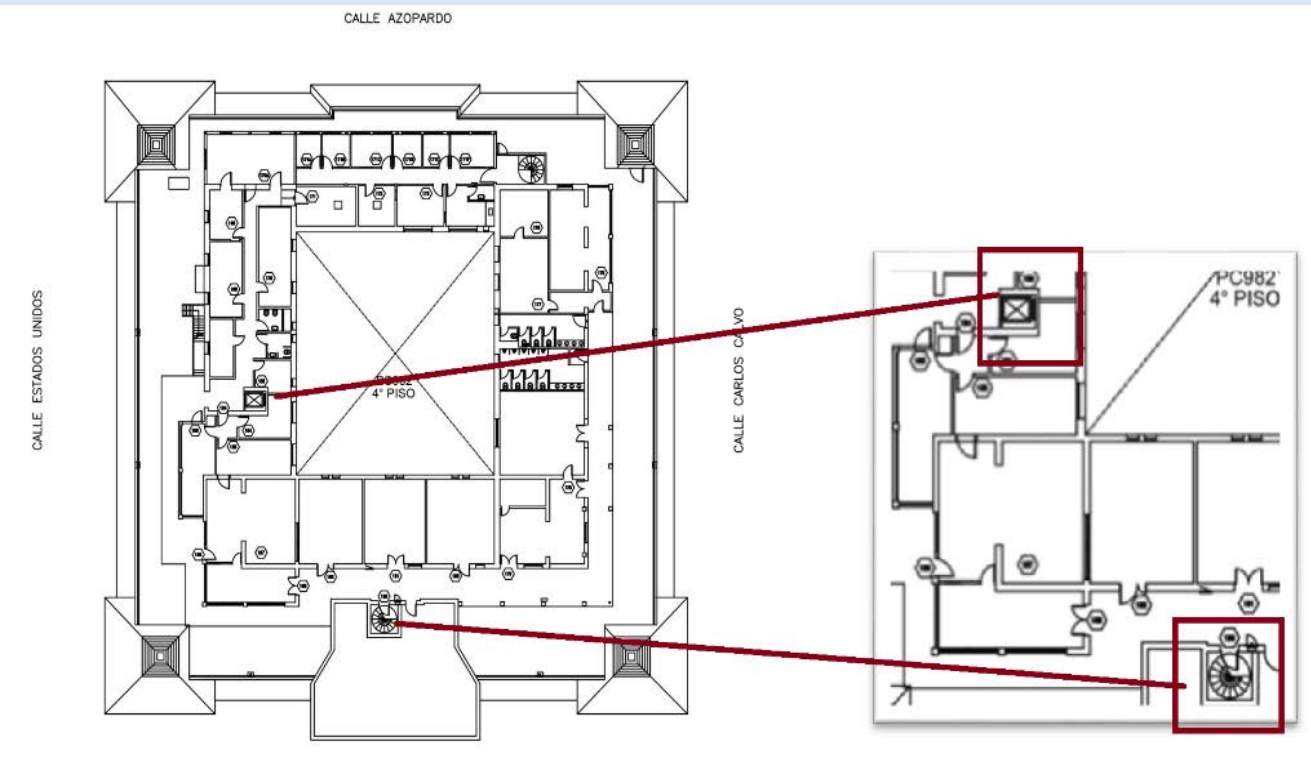

CALL PASEO COLON

Fig. $N^{\circ} 80$ y No 81.- Planta General del 4to piso PC No 982 y detalle de las circulaciones verticales. (Plano AutocaD, Autoría propia - Año 2018). 


\section{MAESTRÍA EN CONSERVACIÓN, RESTAURACIÓN E INTERVENCIÓN DEL PATRIMONIO ARQUITECTÓNICO \\ Y URBANO (CRIP - FAU / UNLP)}

Estas deficiencias se toman como punto de partida para la propuesta de intervención que deberá cumplir con lo especificado en el Anexo I. Art.9 de la ley $26.378,2008^{36}$ y las normas complementarias del Código de Edificación Protección contra incendios medios de salida- ordenanza $N^{\circ} 45.425^{37}$, según se detalla a continuación:

El Anexo I. Art.9 de la Ley $\mathrm{N}^{\circ} 26.378$ establece que:

"A fin de que las personas con discapacidad puedan vivir en forma independiente $y$ participar plenamente en todos los aspectos de la vida, los Estados Partes adoptarán medidas pertinentes para asegurar el acceso de las personas con discapacidad, en igualdad de condiciones con las demás, al entorno físico, el transporte, la información y las comunicaciones, incluidos los sistemas y las tecnologías de la información y las comunicaciones, $y$ a otros servicios e instalaciones abiertos al público o de uso público, tanto en zonas urbanas como rurales. Estas medidas, que incluirán la identificación y eliminación de obstáculos y barreras de acceso, se aplicarán, entre otras cosas, a:

a) Los edificios, las vías públicas, el transporte y otras instalaciones exteriores e interiores como escuelas, viviendas, instalaciones médicas y lugares de trabajo; (...)".

Por su lado el Artículo 1: Punto 1.4 menciona que:

\footnotetext{
'Las escaleras serán construidas en tramos rectos, no admitiéndose las denominadas compensadas, debiendo poseer en todos los casos las respectivas barandas pasamanos".
}

Dicha situación no se verifica en la actual escalera que comunica el cuarto piso con el próximo inferior a este.

\footnotetext{
${ }^{36}$ Ley N²6.378:" Convención sobre los derechos de las personas con Discapacidad y su protocolo Facultativo".

${ }^{37}$ Código de Edificación Protección contra incendios - medios de salida- ordenanza No 45.425 ${ }^{37}$ B.M. 19.287 (Publicada el 19/05/1992) y disposiciones complementarias.
} 
Por último, se establecerán los lineamientos básicos para la materialización de cada una de las propuestas mencionadas.

\subsubsection{Pautas Generales de mantenimiento preventivo.}

Si bien los tratamientos serán diferentes según los sectores en los que se trabajará, se procurará respetar las especificaciones internacionales en lo que hace a la conservación de este tipo de construcciones siguiendo las principales recomendaciones: mínima intervención, reversibilidad y notoriedad de las intervenciones.

- Se cree conveniente continuar utilizando los mismos materiales que fueron empleados anteriormente y ejecutar los procedimientos ya testeados, que luego de realizar varias pruebas in situ, fueron los que resultaron ser eficaces.

- Conformar un equipo de trabajo permanente dentro de la DTO del Ministerio que estará guiado por un profesional que tenga la expertise sobre temas patrimoniales. Este equipo será el encargado de relevar periódicamente los edificios para constatar su estado y funcionamiento integral. Llevando un control de las deficiencias y patologías encontradas en cada sector mediante informes mensuales.

- La totalidad de las canaletas deberán someterse a un control regular para evitar obstrucciones o roturas que provoquen luego filtraciones o humedad de los paramentos. Por lo que será necesario verificar el correcto escurrimiento del agua en las mismas y del resto del sistema de desagües.

- La DTO deberá contar con un stock mínimo de productos para el tratamiento de los grafitis (gel removedor, antigrafiti, detergente, etc.) reservado exclusivamente para estas tareas.

- Las operaciones de remoción de grafitis deberán ser siempre controladas por personal técnico. Tanto los que realicen las tareas como quienes las supervisen deberán recibir el entrenamiento previo y no podrán ser ejecutadas por personal tercerizado otorgándolo a la empresa que se encarga de la limpieza, ya que no está preparada ni cuenta con los elementos para hacerlo. 
- Respecto a la intervención del 4to piso con las operaciones recomendadas se desea lograr:

$>$ Liberar la planta de todas aquellas superficies de oficinas no originales que generan espacios de hacinamiento que no cumplen con los requisitos mínimos necesarios en cuanto a estandares de iluminación, ventilación, etc., poniendo en valor aún más la terraza del edificio.

> Incorporar un área de expansión para el personal, el cual estará equipado con nueva iluminación, mesas, sillas y canteros verdes, entre otros. Entendiendo que el verde en las ciudades mejora la calidad de vida de los residentes urbanos, reduciendo los niveles de estrés y generando un espacio de recreación y relajación.

$>$ Sumar medios de escape que garanticen la rápida evacuación del piso en caso de que esto fuera necesario por cualquier situación de emergencia.

\subsubsection{Conclusiones parciales}

Según se describió anteriormente la última intervención realizada en el conjunto, perteneciente al Ministerio de Agroindustria, representó un tratamiento complejo de resolución. Esto es porque más allá del deterioro lógico producto del correr de los años, en las diferentes gestiones se fueron haciendo sucesivas intervenciones. Muchas de ellas sin seguir ningún criterio estético ni respondiendo a los principios básicos de la restauración. Tampoco se tiene documentación escrita sobre que fue lo que se hizo exactamente ni la fecha de realización.

Sumado a lo expuesto, actualmente se evidencian nuevos deterioros que podrían haberse evitado si se tomaban las precauciones del caso y se seguían las indicaciones de los manuales de mantenimiento que las empresas adjudicatarias, entregaron a la Dirección Técnica Operativa (DTO) al momento de finalizar las obras. Y si se contemplaba lo 
descripto en los informes del asesor contratado para seguir los trabajos de puesta en valor del conjunto.

\subsection{Conclusiones}

En esta nueva instancia en la que se estudia la situación edilicia actual del complejo surge la necesidad de tomar intervención en aquellas patologías que requieren una pronta atención (ir de lo más grave a lo más leve, de lo general a lo particular).

Para ello se debe comenzar por realizar un relevamiento minucioso de cada sector, tanto a nivel exterior como interior.

Siendo fundamental hacer hincapié en la toma de conciencia principalmente por parte de las autoridades del organismo acerca de la importancia de operar sobre el bien siguiendo protocolos predeterminados.

Entendiendo que aún con el fin de resolver una deficiencia edilicia muchas veces se puede provocar un daño mayor si no se utiliza el método eficaz para solucionarlo.

De esta forma es posible llevar un control preciso sobre la correcta de ejecución de las tareas, tomando como referencia los procedimientos que se emplearon en la última intervención edilicia (los materiales, las herramientas, etc.) de los cuales se obtuvieron resultados óptimos, para continuar operando en ese mismo sentido. Ya que además estos procedimientos garantizan un ahorro considerable de tiempo y dinero para quienes tienen que mantener los edificios en buenas condiciones de uso y funcionamiento pleno.

En el capítulo siguiente se describirán los lineamientos para la conservación e intervención del conjunto edilicio Ministerio de Agroindustria, que serán fundamentales seguir de ahora en más para que este pueda ser disfrutado por esta generación y las venideras. 


\section{Capítulo V.- LINEAMIENTOS PARA LA CONSERVACIÓN E INTERVENCIÓN EDILICIA}

Preguntas claves:

¿Cuáles son los mecanismos de difusión y comunicación interna que podrían implementarse a corto plazo para asegurar la correcta conservación del conjunto?

¿Qué instrumentos y acciones legales podrían ponerse en práctica para garantizar la preservación del conjunto?

5.1. Instrumentos para la Conservación e Intervención del conjunto edilicio.

\subsubsection{Protocolos}

5.1.2. Entrevistas a personal del Ministerio. Testimonio Oral.

5.1.3. Noche de los Museos. Abrir el Ministerio a la ciudad.

5.1.4. Declaratoria de Monumento Histórico Nacional.

5.1.5. Conclusiones parciales. 


\subsection{Instrumentos para la Conservación e Intervención del conjunto edilicio.}

Podría decirse que actualmente el conjunto edilicio se encuentra en un período de alta vulnerabilidad.

Es posible llegar a esa conclusión a partir de observar su estado general y analizar cómo distintos factores promovieron su rápido deterioro, aun cuando este había sido intervenido recientemente. Según lo mencionado anteriormente distintos sucesos acontecidos en los edificios a raíz de hechos vandálicos, sumado a decisiones equivocadas tomadas por autoridades del Ministerio para contrarrestarlos, hicieron que se dejaran de lado criterios básicos de intervención a los que se había arribado luego de un estudio profundo del caso en toda su extensión.

Es por ello que se hace imprescindible tomar medidas en forma inmediata para que el daño evidenciado no se convierta en un mal de mayor envergadura con consecuencias irreversibles.

Entre las posibles medidas a implementar se contemplan aquellas que permitan colaborar con la toma de consciencia de la comunidad en general acerca del valor del bien en cuestión y la importancia de cuidarlo entre todos. Se debe comenzar por los funcionarios del Ministerio ya que son quienes tienen un rol fundamental en cuanto a las decisiones que son convenientes tomar. Siguiendo por el personal que asiste al lugar cotidianamente y hacen uso permanente del bien. Las empresas tercerizadas también cumplen un rol primordial por cuanto las acciones que ejercen sobre los inmuebles pueden ayudar a prevenir o deteriorar aún más el estado de conservación de sus componentes.

Por último, se apuntará a la sociedad en general buscando promover el conocimiento del conjunto y su valoración.

> Para poder cumplir con estos objetivos se hará uso de las siguientes herramientas:

Se comenzará por la redacción de protocolos de uso interno que también podrían utilizarse en el caso de contrataciones para ejecución de trabajos terciarizados. 
Luego se describirán las entrevistas personales realizadas a personal pronto a jubilarse, que contaban con décadas de servicio, recabando historias y anécdotas vividas en el sitio a fin que dichos relatos no se pierdan en el tiempo.

Se supone que, al dar a conocer estos relatos a la comunidad no solo representarán el reflejo de vivencias acontecidas en los edificios mencionados, sino que también permitirán conocer espacios que fueron desapareciendo en el tiempo ya sea porque se demolieron o porque se transformaron en nuevos sectores de trabajo.

Por otro lado, estas entrevistas logran reivindicar a los trabajadores ya que el hacerlos participar los hace sentir parte de la historia del lugar.

También vale mencionar un evento anual denominado: La noche de los Museos, en cuanto es una fecha que permite abrir las puertas del Ministerio a la ciudadanía en general para dar a conocer el origen de organismo y las tareas que allí se fueron desarrollando a lo largo del tiempo.

Por último, se considera como herramienta fundamental para la conservación del conjunto poder avanzar en la solicitud de la declaratoria de Monumento Histórico Nacional. La obtención de dicha ley constituirá un instrumento formal y jurídico para garantizar el cuidado que el bien merece.

\subsubsection{Protocolos}

A. Protocolo General para empresas

B. Protocolo para empresa de limpieza que presta servicio en el Ministerio

\section{A. Protocolo General para empresas}

PROCEDIMIENTOS Y CUIDADOS QUE DEBEN TENER EN CUENTA LAS EMPRESAS CUANDO REALICEN TRABAJOS EN EL CONJUNTO EDILICIO MINISTERIO DE AGROINDUSTRIA. 
La presente guía de procedimientos refiere a la protección integral de los espacios de que integran el Ministerio de Agroindustria, su mobiliario y equipamiento antiguo, entendiendo, según lo que se detalló en capítulos anteriores, está alcanzado por el Decreto 1063/82 (de la Ley predecesora 12.668 y su modificatoria 27.103 ) que establece que los edificios de más de 50 años de antigüedad, propiedad del estado nacional, están tutelados por la Comisión Nacional de Monumentos, de Lugares y de Bienes Históricos.

Por otra parte, se encuentra dentro del Área de protección Histórica (APH) y posee una catalogación singular con protección Estructural. ${ }^{38}$

Por lo expuesto, toda empresa subcontratada antes de iniciar sus tareas, deberá prever las siguientes consideraciones:

\section{$\checkmark$ Tareas Previas}

Para poder ingresar al organismo, la empresa entregará al responsable técnico del seguimiento de las tareas (RTST) el listado completo del personal, los materiales y equipamiento que utilizará para la ejecución de los trabajos contratados.

La empresa presentará toda la documentación requerida previamente, el plan de trabajo y material complementario como; catálogos, certificados, ficha de uso, de toxicidad de los productos, etc. Solo podrá dar inicio a sus tareas si la documentación resulta aprobada en su totalidad.

Posteriormente, la empresa coordinará el inicio de las tareas con el RTST y las áreas involucradas esto es; con los responsables de los sectores en donde se trabajará (cuando se trate de oficinas o espacios de uso común como el comedor, la biblioteca, etc.). Se establecerán además los tiempos de obra y horarios, a fin de evitar perjudicar el normal funcionamiento del área. Salvo cuando la magnitud de tarea a ejecutar requiera que el personal deba trasladarse a cumplir la jornada laboral en otro sector del edificio, hasta tanto estas se terminen por completo y vuelva a habilitarse ese espacio para su uso.

\footnotetext{
38 según ley $2548 / 07$ y su modificatoria 3056/09.

Conjunto Edilicio Ministerio de Agroindustria de la Nación (ex Asilo Nocturno de la Capital)
144 "Desarrollo de los instrumentos para la Conservación e Intervención del Patrimonio
Arquitectónico. Hacia un Plan de Gestión".
} 


\section{$\checkmark$ Protección integral de los sectores de trabajo}

La empresa realizará el registro fotográfico del mobiliario, los objetos decorativos, la papelería y accesorios que se encuentren en el sector de trabajo. Las imágenes servirán de ayuda memoria para el posterior control y reubicación de los elementos descriptos. Esta tarea será llevada a cabo bajo la supervisión del RTST expresamente autorizado a tal fin.

Estará a cargo de la empresa, la provisión de los materiales necesarios para proteger todas las superficies de índole edilicia, evitando así que pudieran sufrir daños por acumulación de polvo o por golpes.

En relación al mobiliario será el RTST quien indique en cada caso cual retirará y pondrá a resguardo o aquel que cubrirá completamente y permanecerá en su sitio.

Los muebles no podrán arrastrarse, siendo imprescindible evitar cualquier movimiento inadecuado que pudiera ocasionar rayones y/o roturas en los pisos o en los propios objetos. De ser necesario el traslado de un mueble, se notificará al RTST quien evaluará que procedimiento se deberá llevar a cabo y determinará el personal que estará a cargo de dicho desplazamiento.

Cuando el mobiliario y resto de equipamiento como cuadros, esculturas, lámparas, etc.- existentes en el sector formen parte del inventario del Programa de Patrimonio Cultural del Ministerio, la empresa solo podrá comenzar los trabajos una vez que éstos sean retirados o cubiertos completamente con algún material de protección, como láminas de burbujas de polietileno (Pluribol) según lo que establezcan los responsables del área mencionada.

Cuando el trabajo contratado no incluya tareas específicamente sobre los pisos, éstos deberán cubrirse en su totalidad. En el caso que se trate de pisos históricos de madera, la empresa proveerá y colocará por encima de estos, rollos de nylon y cartón corrugado en un total de tres (3) capas, asegurando su completa aislación. Para labores particulares que afecten otros componentes edilicios como: puertas, ventanas, etc.- la empresa además utilizará fenólicos y todo elemento de resguardo adicional que el RTST solicite. 
Las protecciones siempre serán sobrepuestas y aseguradas mediante fijaciones no agresivas como cintas adhesivas, cuerdas, etc., y retiradas con sumo cuidado una vez finalizadas las labores. Quedando terminantemente prohibido la fijación a las partes originales mediante elementos que puedan dañarlas, como clavos, ganchos, alambres, o tornillos.

Las alfombras serán enrolladas por personal de mantenimiento, trasladándolas al lugar que el RTST designe para su guardado provisorio. El mismo procedimiento aplicará a los cortinados y sus accesorios. Estos deben plegarse con sumo cuidado, transportándolos fuera del ámbito de trabajo.

A su vez, la empresa deberá proveer y colocar todas las defensas, vallados, etc. exigidos por la normativa vigente, que resulten necesarios para la seguridad del edificio y de las personas en general. Siendo la única responsable por los daños o los deterioros que pudiera provocar su falta, pudiendo ser sancionada y quedando a su cargo, los gastos que acarree su reparación.

En el caso que, para la ejecución de tareas en altura la empresa requiera la utilización de andamios o plataformas elevadoras, presentará ante la DTO, el procedimiento de trabajo seguro. Quedando esta última facultada para solicitar documentación complementaria o exigir los cambios que considere necesarios para la correcta implementación de los medios de elevación, la seguridad de los espacios y las personas.

El responsable técnico o representante de la empresa no podrá dar inicio a las labores hasta tanto no tenga la correspondiente aprobación por parte del RTST la DTO.

Será requisito excluyente que, para estos procedimientos en altura o de mayor complejidad, el responsable de Higiene y seguridad de la empresa acompañe los trabajos en todo momento y hasta su culminación. 


\section{$\checkmark$ Procedimiento para el ingreso de materiales, equipamiento y herramientas}

El responsable técnico o representante de la empresa no podrá dar inicio a las tareas hasta tanto la totalidad de las superficies de las áreas a intervenir y los espacios de circulación estén protegidos.

A partir de entonces podrá acercar al sector de trabajo, el resto de los materiales que utilizará, las herramientas, las maquinarias, los andamios o escaleras, extensiones eléctricas, etc.- indispensables para la ejecución de su tarea.

Será responsabilidad de la empresa tener especial cuidado en el traslado de los mismos y durante todas las etapas de permanencia en el Ministerio. Las carretillas o zorras para el transporte de materiales, deberán tener ruedas de goma, al igual que toda maquinaria o equipo desplazado sobre ellos. Asimismo, la empresa colocará terminales de protección en los extremos de los andamios, las escaleras, carros y zorras evitando que un mal movimiento o golpe pudiera provocar daños en las superficies en contacto con estos.

Por otro lado, se aclara que los solados de las áreas de circulación utilizadas para el transporte de estos elementos deben cubrirse en su totalidad. La empresa deberá proponer al RTST el material que utilizará para ello, pudiendo ser: alfombras, mantas, etc.- siempre que cumplan con su función de protección y no entorpezcan el movimiento de las personas y/u objetos. Si lo considerara necesario RTST indicará el retiro, corrimiento o cubrimiento del mobiliario y todo el equipamiento afectado al paso de los materiales y maquinaria, tarea que estará a cargo de su personal de mantenimiento.

Ante la necesidad de la utilización de equipamiento para soldadura del tipo eléctrica es OBLIGATORIO poner en conocimiento y solicitar el aval previo de los responsables eléctricos de la administración de servicios generales del organismo para la alimentación y conexión correspondiente.

La empresa contratada deberá incluir en su plan de trabajo la provisión de la totalidad del equipamiento, materiales, ropa, EPP, incluyendo los insumos y 
maquinaria de limpieza, etc.- que fueran necesarios para la correcta realización de sus tareas.

\section{QUEDA TERMINANTEMENTE PROHIBIDO QUE LA EMPRESA SOLICITE EN PRÉSTAMO AL PERSONAL DEL MINISTERIO, CUALQUIER ELEMENTO DE TRABAJO.}

\section{$\checkmark$ Metodología de limpieza e insumos}

La empresa contratada está obligada en todo momento a mantener el orden y la limpieza de los lugares donde realiza sus tareas y en aquellos que utiliza como circulación.

Tendrá a su cargo la provisión y traslado de todos los insumos y maquinarias de limpieza que requiera para el correcto cumplimiento de las labores, como así también de su retiro una vez finalizados los mismos. Debiendo presentar previamente, los catálogos, certificados de idoneidad, fichas de uso y de toxicidad de los productos que empleará y ser aprobada por el RTST de la DTO, ajustándose a toda modificación o pedido de información complementaria que este considere necesario adicionar.

Realizará una limpieza constante para evitar la acumulación de polvo ya que este puede crear un ambiente húmedo atrayendo y alojando plagas, transportando contaminantes y causando manchas. A la vez tendrá en cuenta que una práctica inadecuada durante estos procedimientos o el uso de productos incorrectos, pueden suponer un elevado nivel de riesgo y deterioro para los bienes. Esto implicaría la necesidad de realizar intervenciones posteriores, con el consiguiente coste económico que estas tareas demandarían. Por esa razón es importante que la empresa siga las recomendaciones vertidas en la presente, a fin de determinar la metodología de limpieza e insumos a utilizar y las consideraciones generales en cuanto al manejo de su personal. 
En todos los casos la limpieza siempre deberá ser superficial, con sistemas preferentemente en seco o de tipo mecánicos y sobre aquellas áreas que no comprometan a ningún componente edilicio, ni zonas decoradas o pintadas.

En cuanto a los insumos, se deberá verificar que sean de primera calidad y no contengan químicos ácidos que puedan deteriorar los espacios y su equipamiento. Se emplearán detergentes neutros y productos sin contenido de cloro o amoniaco. Los cepillos y brochas serán siempre de cerdas suaves, estas últimas se utilizarán en superficies rugosas e irregulares, también se usarán mopas o paños de algodón y gamuzas electroestáticas de color blanco.

Las aspiradoras deben serán de potencia regulable.

Todo desperdicio generado durante la ejecución de las labores será acumulado y la empresa llevará a cabo su disposición final en forma periódica o cuando el RTST lo indique. Siendo condición indispensable su total eliminación para dar la recepción definitiva del servicio o el final de obra. Para ello, la empresa proveerá bolsa de residuos negras y verdes que le permitirán separar los residuos según sean reciclables o no.

Una vez que la empresa termine las tareas procederá al retiro de toda la maquinaria y los materiales empleados. Quitará todas las protecciones colocadas al inicio de las tareas y los escombros que aún quedaran en el lugar. Por último, coordinará la limpieza final de los sectores afectados.

Solo podrá efectuarse la recepción definitiva del trabajo una vez que el RTST, realice un control exhaustivo del estado del sector para verificar que este no haya sufrido ningún tipo de daño ni deterioro. De lo contrario tomará las medidas pertinentes, según la gravedad del perjuicio causado.

Con todos los espacios liberados y en perfectas condiciones, el RTST organizará con el personal de mantenimiento, el rearmado de los sectores y el último repaso que estará a cargo de la empresa de limpieza que presta servicio en el edificio. 


\section{$\checkmark$ Consideraciones generales que debe tener la empresa en relación a su personal}

El personal deberá contar en todo momento con uniforme identificatorio de la empresa a la cual pertenece y un cartel visible con su nombre.

Se recomienda que las labores las realicen varias personas a la vez o en cadena de modo de que trabajen en simultaneidad, asistiéndose unos con otros minimizando los riesgos que podrían producirse por cualquier maniobra individual, acortando los tiempos de permanencia en las áreas mencionadas.

La empresa instruirá a su personal para que evite en todo momento el uso de objetos como anillos, cadenas o pulseras que puedan provocar deterioros. Es obligatorio el empleo de guantes, evitando así contaminar los bienes con sudor o suciedad. El tipo de guantes a utilizar, dependerá del material con el cual se tendrá contacto y el peso del objeto a manipular.

En el caso que, durante los procedimientos que realice la empresa suceda algún accidente o fractura ya sea de un componente edilicio u objeto de valor patrimonial, se debe notificar inmediatamente al RTST, quien decidirá los pasos a seguir y las multas o sanciones que le impartirá. Quedando terminantemente prohibido que el personal de la empresa, efectué cualquier tipo de maniobra con el fin de remediar el perjuicio causado, utilizando adhesivos o pegamentos para reparar objetos dañados, etc.-.

La empresa deberá informar a su personal que no podrá hacer uso del mobiliario existente para descansar ni para apoyar sus pertenencias, herramientas, etc.-. Los objetos personales de sus operarios quedarán a resguardo en el lugar designado por la DTO, siendo responsabilidad de la empresa tomar las medidas de seguridad que crea conveniente, sin tener derecho a reclamo alguno por faltantes.

En todo momento la empresa deberá prestar especial atención en el comportamiento de su personal. Cualquier conducta considerada impropia, podrá ser considerada motivo de sanción.

Conjunto Edilicio Ministerio de Agroindustria de la Nación (ex Asilo Nocturno de la Capital) 


\section{B. PROTOCOLO PARA EMPRESA DE LIMPIEZA QUE PRESTA SERVICIO EN EL MINISTERIO.}

\section{GUIA DE PROCEDIMIENTOS ESPECIFICOS PARA REALIZAR LA LIMPIEZA DEL EDIFICIO DEL MINISTERIO DE AGROINDUSTRIA EN LO REFERENTE A ASPECTOS PATRIMONIALES.}

Es de suma importancia establecer una guía de procedimientos en lo referido a la limpieza y el mantenimiento de los distintos sectores de valor patrimonial, que componen el Ministerio de Agroindustria, su mobiliario y equipamiento antiguo, entendiendo que se trata de un conjunto edilicio con protección patrimonial (según lo anteriormente mencionado).

Se parte del concepto de que uno de los principales propósitos de la limpieza regular es controlar el polvo ya que, cuando este se acumula puede crear un ambiente húmedo atrayendo y alojando plagas, transportando contaminantes y causando manchas. Pero a la vez una práctica inadecuada durante estos procedimientos de limpieza o el uso de productos incorrectos, suponen un elevado nivel de riesgo para los bienes. Esto implicaría luego la necesidad de realizar intervenciones con el fin de revertir los deterioros producidos, con el consiguiente coste económico que estas tareas demandarían.

Por esa razón es importante que la Adjudicataria siga las recomendaciones vertidas en la presente, que tendrá como objetivo determinar los lineamientos básicos en cuanto a los cuidados que deberá tener su personal, tanto en lo referente a los edificios principales como a sus anexos.

Esta guía incluirá un listado orientativo de los insumos de limpieza con los que la Adjudicataria deberá trabajar y la forma de operar con ellos.

A su vez se detallarán cuáles son los recaudos especiales que deben tenerse en cuenta en estas tareas para tratar de evitar, neutralizar o minimizar deterioros en los sectores de valor histórico y patrimonial como así también de cada uno de los elementos constitutivos de los mismos, el equipamiento y todas las piezas decorativas que integran el conjunto edilicio en cuestión. 
Para poder cumplir con estas premisas la Adjudicataria tiene la obligación de contar dentro de su staff con un especialista en restauración y conservación patrimonial, quien deberá desempeñar una asistencia de mínimo ocho (8) hs semanales en el lugar y atender permanentemente toda consulta que la Adjudicataria o el responsable técnico del seguimiento de las tareas (RTST) pudiera hacerle. El mismo deberá acreditar idoneidad y experiencia previa en este tipo de tareas.

El especialista deberá realizar un exhaustivo relevamiento y posterior evaluación de los edificios para detectar cuales son los sectores constitutivos más vulnerables y determinar las acciones de limpieza más recomendables para ellos. A su vez mantendrá reuniones periódicas con el RTST. Las mismas servirán para establecer las estrategias y las pautas necesarias para la correcta ejecución de las tareas de limpieza, las que deberán ser aprobadas por este, siempre con anterioridad a su inicio.

Debido a la cantidad de áreas a tratar y la diversidad de los elementos que las componen como: salones, despachos, con sus respectivos materiales constitutivos tales como solados y revestimientos, la Adjudicataria deberá contar con todas las técnicas necesarias y la mayor calidad de productos existentes en el mercado para la obtención de un servicio de excelencia.

En cuanto a los sistemas de limpieza serán preferentemente en seco o de tipo mecánicos, como aspiradoras, cepillos, carros y otros análogos adecuados a la naturaleza de las superficies a limpiar. Estas operaciones se realizarán con la frecuencia adaptada al tráfico, el desgaste y al grado de suciedad de los espacios según propuesta de la Adjudicataria que deberá ser aprobada por el RTST.

La Adjudicataria deberá entregar previo al inicio de las tareas, todos los catálogos, certificado de idoneidad, ficha de uso y de toxicidad de los productos que empleará a la Dirección Técnica. Esta será quien los supervise periódicamente, pudiendo solicitar los cambios o ajustes que considere necesarios. Asimismo, si la Adjudicataria tuviera que variar la marca o modelo de algún producto o material por causa justificada, presentará al RTST, las cartas, muestras, certificados de garantía, etc. que demuestren la capacidad de sustitución del nuevo respecto al primero.

Conjunto Edilicio Ministerio de Agroindustria de la Nación (ex Asilo Nocturno de la Capital) 
Para la limpieza de los sectores de alto valor patrimonial se aconseja que las labores las realicen varias personas a la vez o en cadena de modo de que trabajen en simultaneidad, asistiéndose unos con otros minimizando los riesgos que podrían producirse por cualquier maniobra individual, acortando los tiempos de permanencia en las áreas mencionadas. Estas tareas además deberán ejecutarse bajo la supervisión del especialista en restauración y conservación patrimonial contratado por la Adjudicataria.

\section{$\checkmark$ Metodología básica de limpieza a emplear según las superficies a tratar}

- Para la limpieza mecánica se emplearán detergentes neutros y productos sin contenido de cloro o amoniaco, salvo circunstancias particulares supervisadas por el especialista en restauración y conservación patrimonial contando con la aprobación expresa del RTST.

- Para la limpieza en seco se recomienda utilizar mopas o paños de algodón y gamuzas electroestáticas de color blanco.

- Los cepillos y brochas serán siempre de cerdas suaves, estas últimas se utilizarán en aquellos sectores u objetos cuyas superficies sean rugosas e irregulares.

- Las aspiradoras a utilizar deberán ser de potencia regulable.

- Verificar que los productos usados para la limpieza sean de primera calidad y no contengan químicos ácidos que puedan dañar los inmuebles y sus colecciones.

- Los productos utilizados para la limpieza de maderas y objetos delicados deben ser almacenados diferencialmente para no confundirlos con los de uso general y ser manipulados por personal idóneo para esa tarea específica.

- Si luego de que se efectuaran obras de mantenimiento en algún sector de los edificios, al ingresar el personal de limpieza encontraran cintas adhesivas sobre las superficies tratadas, éstas serán retiradas con sumo cuidado, a fin de no causar faltantes ni abrasiones en las superficies de contacto.

\section{$\checkmark$ Consideraciones generales en cuanto al personal}

La Adjudicataria deberá contar dentro de su staff, con un equipo que tendrá asignada como tarea principal diaria, la limpieza correspondiente al despacho del Ministro, la 
secretaría privada, sala de reuniones y áreas de acceso restringido. El horario de ingreso a esos sectores será a primera hora de la mañana, previo a la llegada del funcionario.

Por otro lado, habrá limpiezas adicionales, esto es, en forma posterior a trabajos de mantenimiento o reparaciones que se realicen eventualmente en algunos de los sectores mencionados. EI RTST será quien determine en qué momento se requerirá la asistencia del equipo y esto será comunicado con anticipación al supervisor de la Adjudicataria para coordinar en conjunto las tareas.

El personal asignado para los sectores en cuestión, deberá ser idóneo y especialmente entrenado. Su rotación será fija y en caso de producirse faltas o ausencias, estas deberán ser cubiertas en forma prioritaria respecto a otras áreas de los edificios, salvo indicación especifica del RTST. Será deber de la Adjudicataria proporcionarles capacitaciones periódicas que involucren formación en materia de seguridad sabiendo cómo proceder en caso de inundaciones, incendio y otro tipo de catástrofes e instrucciones de actuación frente a situaciones varias. Asimismo, el RTST podrá proponer charlas técnicas, que serán obligatorias, sin costo adicional para la Adjudicataria. Estas serán brindadas por profesionales tales como restauradores y especialistas en Patrimonio edilicio y/o de mobiliario, las que proporcionarán conocimientos específicos para perfeccionar los trabajos de limpieza. Los horarios y duración de las charlas serán convenidas entre las partes.

El personal deberá evitar en todo momento el uso de objetos como anillos, cadenas o pulseras que puedan deteriorar las obras o los muebles debido al roce. Mientras realice las tareas de limpieza deberá cubrir y proteger sus manos mediante el uso de guantes evitando así contaminar los bienes con sudor o suciedad. La elección del tipo de guantes a utilizar dependerá del material con el cual se tendrá contacto debido a que estos son capaces de desencadenar reacciones químicas, también se considerará el peso del objeto a manipular porque pueden inhibir la capacidad para sostenerlo entre las manos (ver especificaciones de los distintos tipos).

Las plantas de interior suponen un factor de riesgo debido a que atraen microorganismos e insectos por lo que requieren una limpieza exhaustiva y desinsectación. En caso de detectar cualquier síntoma anómalo, como presencia de insectos deposiciones de carcoma, etc. se deberá proceder de la siguiente forma: localizar objetos dañados o infestados y luego dar aviso al asesor en restauración 
para ponerlo en conocimiento de la situación, quien definirá los procedimientos a seguir previa aprobación del RTST.

En el caso que suceda algún accidente o fractura de un objeto de valor patrimonial se debe notificar al especialista en restauración y conservación patrimonial contratado por la Adjudicataria. No se deben utilizar ningún tipo de adhesivos o pegamentos para repararla.

El mobiliario no deberá arrastrarse dado que cualquier movimiento inadecuado puede ocasionar rayones y/o roturas en los pisos o en los propios objetos. De ser necesario el traslado de un mueble u objeto decorativo, se notificará al especialista en restauración y conservación patrimonial para que informe al RTST y sea esta quien tome la decisión acerca del procedimiento a realizar. Todo deterioro provocado por estas acciones será sancionado y estará a cargo de la Adjudicataria los gastos que acarre su intervención, según lo expresado en el Pliego.

OBRAS DE ARTE: Se deja expresamente especificado que la limpieza y el mantenimiento de la totalidad de las obras de arte quedan excluidas de las tareas encomendadas a la Adjudicataria, quedando a cargo del personal del Programa de Patrimonio Cultural, debido a la especificidad que requiere su tratamiento y el valor artístico e histórico que poseen.

Cuadros modernos que posean vidrio por delante deberán ser limpiados retirando todo resto de polvo mediante un paño seco de microfibra, teniendo todos los cuidados del caso durante su manipulación.

\section{$\checkmark \quad$ LISTADO ORIENTATIVO DE INSUMOS Y PRODUCTOS DE LIMPIEZA:}

- Carros de limpieza con estantes y ruedas.

- Carros con prensa y mopa horizontal.

- Señalizadores de seguridad de piso mojado.

- Mopas de microfibra y gamuzas electroestáticas, franelas, trapos de algodón blanco, trapeadores, lampazo barredor microfibra, brochas suaves, rociadores, 
palas con mango largo, bolsas de residuos, cabos de acero telescópicos reforzados etc.

- Aspiradoras con regulación de potencia.

- Guantes (según se describe a continuación):

- Guantes de algodón blanco: se emplean para la manipulación de hierro, cobre, latón, piedras, cerámica, vidrio y textiles. Se usan con los guantes de nitrilo debajo para evitar que el sudor de las manos los manche.

- Guantes de látex natural: serán utilizados teniendo en cuenta que son incompatibilidades con algunos materiales y pueden causar ennegrecimiento de la plata.

- Guantes de nitrilo libres de látex: estos serán utilizados cuando existan riesgos químicos, o se manipulen objetos a la excepción de la plata y las fotografías.

- Guantes de nitrilo y de látex natural: se utilizarán en trabajos cortos y temporales.

- Guantes de cuero: se emplearán para manipular los objetos pesados con superficies difíciles de agarrar.

- Guantes con estructura dentada: deben utilizarse únicamente para objetos pesados con superficies difíciles de agarrar.

- Detergentes y jabones neutros, limpiador de vidrios en aerosol, selladores acrílicos tipo Sutter o similar, etc.

Las cantidades deben ser determinadas por la Adjudicataria y dependerán tanto de las características propias de los edificios y las necesidades a cubrir, como del número de personal distribuido en cada uno de ellos.

\section{MÉTODOS DE LIMPIEZA SEGÚN LOS MATERIALES CONSTITUTIVOS DE LOS ESPACIOS:}

Pisos duros y porosos: (mármol, mosaicos, etc.-) Estos pisos se tratarán con sellador disuelto en agua de carácter neutro, convirtiéndose así en una superficie impermeable y homogénea en la que la suciedad no penetre y resulte de fácil remoción. Se abrillantarán periódicamente con productos antideslizantes cristalizadores, empleando la maquinaria y los procedimientos adecuados de forma que no se altere el estado natural de los mismos. La frecuencia de esta 
operación estará vinculada al tipo de tráfico, el desgaste y el grado de suciedad. Será estipulada de tal forma que los espacios se encuentren limpios, pero no se realicen con exceso para evitar la acumulación del producto sobre la superficie.

Pisos minerales no porosos: tipo granito, etc.- se tratarán mediante aspiración manual o mecánica y barrido húmedo con mopa de microfibra para evitar el desplazamiento del polvo en el ambiente. Se fregará manualmente con mopa de microfibra y detergente desinfectante neutro o cepillo de nylon adaptándose al tráfico de cada zona, desgaste o grado de suciedad.

Pisos de madera: Serán limpiados con mopas electroestáticas o aspiradoras. Nunca barridos ya que de esa forma se provoca la dispersión del polvo y que gran parte del mismo vuelva a asentarse concluida la tarea. Se debe evitar la limpieza con agua y en caso que esta sea necesaria se fregará con jabón neutro y después se hará una segunda pasada con agua limpia y muy escurrida, dejando ventilar para que se seque lo antes posible.

Pisos de alfombra y textilería de valor patrimonial: La Adjudicataria, bajo el asesoramiento de su especialista en restauración, propondrá el sistema de limpieza a emplear, debiendo ser aprobado por la Dirección Técnica antes del inicio de las tareas.

No estará permitido utilizar un sistema de aspiración directamente sobre el textil, en tal caso la aspiración será a través de un pequeño aro de bordado cubierto con tul para proteger las secciones frágiles y las superficies de decoración. Esta tarea estará a cargo de personal capacitado y bajo la supervisión del especialista en restauración. No se empleará agua, detergentes, alcohol ni otras soluciones. El lavado en estos casos no debe ser un método de limpieza de rutina por los riesgos que conlleva el proceso y solo en caso que se considere necesario se preparará un baño de agua poco profundo usando jabón puro, enjuagando la pieza a fondo con agua limpia (desmineralizada) y secándola a la sombra. 
Mármoles: (Antepechos, escalones, etc.-) Debido a la porosidad del material se aplicará una limpieza en seco utilizando mopas de microfibra a efectos de mantenerlos sin polvo y en perfecto estado de conservación.

En caso de requerirse trabajos más específicos, los mismos estarán a cargo de personal idóneo y capacitado contando con la protección personal requerida por la normativa de seguridad e higiene vigente (guantes, antiparras, etc.-) bajo la supervisión permanente del especialista en restauración de la Adjudicataria durante todo proceso que se lleve a cabo.

Los mármoles manchados serán repasados empleando esponjas de espuma, cepillos de filamentos plásticos y detergente enjuagándolos con agua limpia. Manchas rebeldes podrán retirarse mecánicamente con espátulas, bisturíes o mediante la aplicación de compresas de pulpa de celulosa con agua o gel removedor, según corresponda. Si estas son de óxido de hierro se quitarán aplicando ácido cítrico en solución, cuya concentración será la más baja posible y controlando el tiempo de exposición. Para retirar grasitud se agregará al agua de lavado unas gotas de amoníaco.

De ser necesario mejorar el aspecto de los mármoles podrá realizarse un pulido manual muy suave únicamente con lijas al agua de grano fino, previo ensayo a cargo del especialista en restauración de la Adjudicataria y expresa aprobación del RTST. No se admitirán otros tratamientos que pudieran dañar los mármoles.

Techos, paredes y carpinterías: Techos y paredes siempre se limpiarán en dirección de arriba hacia abajo. Aquellas superficies que sean lavables, se fregarán con mopa de microfibra, utilizando una solución de detergente desinfectante neutro tibio, según la frecuencia necesaria.

Las carpinterías de cedro se limpiarán únicamente con mopa de microfibra electroestática en seco, retirando el polvo de la superficie. En caso de requerirse un tratamiento mayor, el mismo será estudiado por el especialista en restauración quien evaluará el mejor método de limpieza y lo elevará a la Dirección Técnica para su correspondiente aprobación.

Arañas y artefactos eléctricos de estructura metálica: La limpieza deberá realizarse con los insumos correspondientes en función de la tipología del objeto. 
Para las arañas se recomienda no girar las mismas con el fin de evitar que se desenrosquen y caigan. Se retirará el polvo con plumeros de microfibra electroestáticos secos y cabos telescópicos.

Herrajes y elementos decorativos metálicos: Se deberá eliminar el polvo que quede en las superficies de metal, ya que puede causar corrosión, siendo la limpieza con un paño suave o mediante aspiración manual los métodos más efectivos.

Los aceros inoxidables y aluminios se limpiarán con detergentes neutros prohibiéndose el uso de limpia metales y productos químicos debido a que pueden dejar residuos en la superficie y los abrasivos pueden alterar el anodizado del aluminio.

Las barandas metálicas se limpiarán con mopa de microfibra, teniendo especial cuidado con las áreas superficiales oxidadas, corroídas e inestables. Los objetos de plata solo se repasarán cuando sea realmente necesario, ya que si la limpieza es excesiva los pueden desgastar. El deslustre ligero a menudo puede eliminarse con un paño de algodón.

Revestimiento de madera (Boiserie) Serán repasados con mopa seca y cuando su estado lo requiera ésta se humedecerá levemente con un producto apto para este tipo de superficies. Este nunca debe aplicarse directamente sobre el material, ya que puede deteriorarlo.

Mobiliario, objetos decorativos y obras de arte de valor histórico En todos los casos se deberá evaluar el material del objeto y su condición, ya que los mismos requieren una atención especial para preservarlos y evitar cualquier daño.

La limpieza se realizará siempre de adentro hacia afuera y de arriba hacia abajo teniendo especial cuidado al limpiar las superficies dañadas o sueltas, quitando el polvo y las marcas producidas por roces utilizando aspiradora de succión reducida o cepillos de microfibra. La frecuencia del tratamiento y su mantenimiento periódico serán los que se consideren adecuados y podrán ser incrementado por pedido expreso de la Dirección técnica o por circunstancias especiales que así se requieran. 
No utilizar productos aceitosos, agua ni detergentes ni alcohol, ni limpiadores de muebles domésticos debido a que poseen silicona y colorantes que se transferirán al objeto durante el proceso.

No se deben limpiar las áreas decoradas o pintadas que están descascaradas ni dañadas en cuyo caso se solicitará asesoramiento al especialista en restauración de la Adjudicataria.

El cuero deberá limpiarse solo si es necesario y el objeto está en buenas condiciones. En ese caso la limpieza será de baja aspiración o con cepillos suaves, pero sin arriesgarse a raspar la superficie. Para cueros más delicados deberán usarse otros métodos.

En caso que hubiere elementos con terminación en dorado a la hoja deberán ser limpiados con sumo cuidado con pinceletas o cepillos de cerda suave y si las superficies no presentan deterioros.

En esculturas retirar el polvo mediante pinceles y brochas de cerdas suaves, sin utilizar ningún tipo de líquidos o elementos que pueda remover la policromía.

Para materiales como vidrio, porcelana y cristalería se usarán paños blancos levemente humedecidos. Para las piezas cerámicas se emplearán cepillos de cerdas suaves. No se usará agua ni detergentes. Los exteriores de las vitrinas se podrán limpiar con productos comerciales, aplicados directamente sobre el paño de limpieza con rociador, no sobre la superficie de la vitrina, para evitar que eventualmente pueda ingresar liquido dentro de ellas.

En caso de piezas antiguas como vasijas, copones, etc. se evaluarán los procedimientos a seguir en forma individualizada y consensuada por las partes, consultando además con el Programa de Patrimonio Cultural del Ministerio.

\subsubsection{Entrevistas a personal del Ministerio. Testimonio Oral}

Acorde se tuvo conocimiento de que varios agentes tenían más de veinticinco (25) años ininterrumpidos en el organismo y estaban prontos a jubilarse se comenzó a pensar en la posibilidad de realizar una serie de entrevistas para dejar asentadas las experiencias de cada uno de ellos en sus años de servicio. 
Así fue que se les consultó acerca de la posibilidad de llevar a cabo esta labor por medio de una filmación en video y también con grabador de voz. Con estas dos modalidades se pretendía por un lado conservar el material en video para luego compaginarlo como parte de un documental y por el otro tener el material en versión oral para luego traspasarlo a papel.

A partir de esa idea inicial se generó un pequeño cuestionario y se convocó a cada uno de los agentes en forma individualizada. Las grabaciones se llevaron a cabo hacia finales del año 2017 durante dos (2) semanas consecutivas y el material fue transcripto días después.

El resultado de las entrevistas fue altamente productivo ya que los agentes narraron situaciones vividas dentro del Ministerio, algunos de ellos desde pequeños debido a que sus padres habían sido empleados del lugar y lo visitaban desde temprana edad. También resultó interesante la descripción de sectores actualmente inexistentes que fueron demolidos años atrás y acontecimientos históricos inéditos que no quedaron asentados en escritos pero que ellos habían transitado trabajando ahí.

Por otro lado esta iniciativa resultó ser muy gratificante para ellos, ya que lo sintieron como un gesto de reconocimiento por tantos años de trabajo, motivo por el cual se manifestaron sumamente agradecidos.

\subsubsection{Noche de los Museos. Abrir el Ministerio a la ciudad}

La noche de los Museos es un evento cultural organizado a nivel mundial y en forma conjunta por numerosos museos e instituciones culturales, que se lleva a cabo durante una noche al año entre las $20 \mathrm{pm}$ y las 3.00 am cuando los establecimientos abren sus puertas a la comunidad para poder ser visitados.

El evento busca introducir nuevas personas a las instituciones culturales permitiendo acceder en forma gratuita a todas las exhibiciones y otorgando por esa noche la libre circulación en transporte público para poder visitar distintos espacios participantes de la actividad. 
Se organiza desde hace dieciseis (16) años en forma ininterrumpida, hacia el primer fin de semana de noviembre en la ciudad de Buenos Aires siendo el Ministerio de Agroindustria es uno de los sitios participantes.

En lo que refiere al organismo, el Programa de Patrimonio Cultural es el área encargada de la organización de todas las propuestas de la noche. A través de muestras colectivas de artistas nacionales, llevando a cabo recorridas guiadas por los edificios y sobretodo buscando año a año el modo de contar a los visitantes la historia del origen del conjunto.

En el año 2017 se realizó un video institucional del cual participaron algunos de los profesionales que formaron parte de las tareas de puesta en valor, entre ellos: periodistas, consultores, historiadores y personal en general.

Dicho video fue exhibido La Noche de los Museos siendo muy bien recibido por los visitantes de esa noche. El mismo se vuelve a exhibir cada año durante el mes de noviembre cuando se realiza este evento y además forma parte de los videos subidos a la página oficial del Ministerio, ${ }^{39}$ lugar en el que aún permanece para poder ser visto por el público en general.

\subsubsection{Declaratoria de Monumento Histórico Nacional}

La voluntad de llevar a cabo la solicitud de declaratoria de Monumento Histórico Nacional es una iniciativa que lleva larga data.

El objetivo es que el conjunto Ministerio de Agroindustria pase a integrar la lista de los Monumentos Históricos Nacionales, mediante la elaboración de un proyecto de decreto a ser firmado por el PODER EJECUTIVO NACIONAL.

Durante distintas gestiones, el Programa de Patrimonio Cultural del organismo propuso llevar adelante esta tarea, sin embargo, nunca se logró que las autoridades acompañaran fervientemente esta iniciativa motivo por el cual no se avanzó en ello hasta ahora.

\footnotetext{
${ }^{39}$ Documental: Restauración del conjunto edilicio Ministerio de Agroindustria, año 2016, video recuperado de http://www.minagri.gob.ar/sitio/areas/patrimonio/videos/ - fecha 04/11/2019 


\section{MAESTRÍA EN CONSERVACIÓN, RESTAURACIÓN E INTERVENCIÓN DEL PATRIMONIO ARQUITECTÓNICO \\ Y URBANO (CRIP - FAU / UNLP)}

Se parte de la base que, según la disposición $N^{\circ} 6 / 91^{40}$ de la Comisión Nacional de Monumentos, Lugares y Bienes Históricos, se establece que para elevar la solicitud de declaratoria del organismo se debe reunir la siguiente documentación (Art. $N^{\circ} 3$ ):

Regístrese, comuníquese, cumplido archívese.

Comisión Nacional De Museos, Monumentos y lugares Históricos

Requisitos para la Declaratoria de Monumentos Históricos.

La Comisión Nacional de Museos, Monumentos y Lugares Históricos, resolvió, para sistematizar la información de los monumentos históricos, que todo pedido de declaratoria deber presentarse acompañado de la siguiente documentación histórica, jurídica y técnica que facilite su evaluación por parte de la Comisión.

1. Denominación y localización del Monumento.

2. Títulos de propiedad, nombre y dirección del propietario.

3. Inscripción de dominio en el Registro de la Propiedad (número de finca, zona, tomo y folio)

4. Situación jurídica del bien. Hipotecas, gravámenes, etc.

5. Memoria histórica. Antecedentes de la realización del edificio, acontecimientos históricos a los que se lo vincula. Valores artísticos y culturales. Diversos usos que ha tenido. Función actual.

6. Criterios de valoración que justifiquen su declaratoria como Monumento Provincial y como Monumento Nacional.

7. Plano de mensura, datos catastrales (circunscripción, sección, manzana y parcela)

8. Estado actual de la Obra, Planos de plantas, fachada y dos cortes (transversal y longitudinal) (esc. 1:100).

Fotografías en blanco y negro exteriores e interiores.

Memoria descriptiva del estado del edificio en sus aspectos técnicos y funcionales. Estado de mantenimiento, estimación de costos previstos para la refacción si es necesaria.

Probables disponibilidades de recursos.

40 Disposición Nª 6/91, Buenos Aires, 21 de octubre de 1991. 
9. En caso de pensarse un cambio de funciones del Monumento; destino que se le daría, programa de funciones y criterios de restauración propuestos. Sistema de administración y gestión en el uso del monumento.

10. Todos los pedidos deberán canalizarse por las delegaciones provinciales.

11. Las delegaciones elevarán el pedido a la Comisión Nacional de Museos, incluyendo un proyecto de coparticipación municipal, provincial y nacional en lo que corresponde a los gastos de puesta en valor, expropiación, etc.

12. Otros aspectos que se consideren de interés.

Nota.

Por todo lo referido en el presente documento, se considera que es de suma importancia volver a retomar esta iniciativa a la mayor brevedad posible.

\subsubsection{Conclusiones parciales}

Por todo lo expuesto detalladamente a lo largo de los capítulos precesores que componen el presente, se estima urgente llevar adelante todas las gestiones y trabajos que se crean convenientes con el fin de mantener en óptimas condiciones, cada uno de los sectores constitutivos del bien en cuestión, siendo fundamental para su correcta preservación en el tiempo.

Haciendo foco en la divulgación por parte de los funcionarios y de las áreas técnicas responsables de la infraestructura edilicia, mediante mecanismos de difusión y comunicación interna, de una adecuada información sobre el buen uso y cuidado de los espacios. Apelando a concientizar a aquellos que habitan diariamente el lugar, quienes pueden accionar directa y positivamente en su conservación.

Por último se entiende que todos los controles internos que puedan realizarse, como por ejemplo relevamientos periódicos y mantenimientos mensuales, pueden colaborar al registro temprano de nuevas patologías que tratadas a tiempo evitan daños mayores a futuro. 


\section{Capítulo VI. - CONSIDERACIONES Y CONCLUSIONES FINALES}

Según lo investigado el conjunto edilicio construido como "Asilo Nocturno de la Capital" eje principal del presente trabajo, se inscribe dentro del campo de la preservación del patrimonio edilicio, siendo las características propias de la obra, la tipología, el destino para el cual fue proyectado y las modificaciones que sufrió antes de su inauguración, material sumamente enriquecedor como fuente de estudio.

Emplazándose en el barrio de San Telmo, dentro del área fundacional de la ciudad, pasó a formar parte de la nueva arquitectura predominante en Buenos Aires hacia comienzos del siglo XX.

En relación a la pregunta formulada en el Capítulo I, sobre cuáles fueron los emergentes arquitectónicos, sociales, políticos - económicos que aparecieron en la época, cómo estos se reflejaron en la arquitectura local y que influencia tuvieron en el proyecto en cuestión, la respuesta está relacionada a la sumatoria de las diferentes condicionantes descriptos a continuación:

- A nivel urbano: su implantación dentro de los límites de la ciudad de entonces, resultaba estratégica en concordancia con la corta distancia del puerto y respecto a otras obras emblemáticas de la nueva Capital.

- A nivel social: la iniciativa impulsada por parte del Estado que procuraba acompañar el proceso inmigratorio mediante nueva legislación, provocó un incremento poblacional exponencial convirtiendo al país en uno de los destinos privilegiados para quienes habiendo dejado sus lugares de origen recomenzaban sus vidas en tierras lejanas. Esto generó la necesidad de contar con espacios para cobijar a los recién llegados, siendo esta la función que promovería el proyecto inicial del conjunto.

Mientras la finalización de la construcción del primer edificio se iba retrasando, en simultáneo se producía una desaceleración en la inmigración y un crecimiento de las actividades agrícolas - ganaderas. 
A fin de dar respuesta a este proceso que comenzó a gestarse, acordes a las nuevas y variadas actividades productivas que ahora se desarrollaban, se optó por cambiar su uso apostando a que el país se convertiría en poco tiempo en una potencia mundial.

- A nivel tecnológico: el gran flujo migratorio sumó mano de obra especializada e inspiró a la elite local y a la clase gobernante a convocar a arquitectos que habían estudiado en Europa, ya que hasta entonces se carecía de formación profesional a nivel nacional. Estos además incorporaron elementos innovadores en las construcciones y técnicas que hasta entonces no habían sido aplicadas en nuestro país.

Como consecuencia de ello, los diseños se volvieron más complejos, apelando a la voluntad de satisfacer los requerimientos de una sociedad que se encontraba en plena transformación.

Por otra parte las interrupciones que tuvieron las construcciones por conflictos internacionales y fuertes variaciones económicas, hicieron que una vez retomadas las mismas, chocaran con la irrupción de grandes avances tecnológicos. Esto exigía la necesidad de reformular los proyectos, ya que se habían convertido en piezas obsoletas y por ende requerían modificaciones o adaptaciones en relación al confort y al uso de los espacios.

- A nivel arquitectónico: tuvo como fuente inspiradora prototipos estéticos europeos, principalmente el francés. Superado el neoclasicismo, el estilo ecléctico se convirtió en el modo de expresar el pensamiento predominante de la época, a través de una construcción mixturada, robusta, de gran escala, cargada de significaciones y a la vez absolutamente austera.

En las fachadas, la utilización de revoques simil piedra, la aparición de materiales importados y de nuevos ornamentos, fueron recursos compositivos caractéristicos que representaron un gran cambio en la arquitectura local.

Las situaciones enunciadas también se vieron reflejadas en otros edificios estatales contemporáneos al Ministerio de Agroindustria, ya que todos fueron concebidos a partir de principios proyectuales similares y en el mismo contexto nacional.

Conjunto Edilicio Ministerio de Agroindustria de la Nación (ex Asilo Nocturno de la Capital) 
Así se pudo establecer un patrón común que reunió las obras públicas dentro de una misma tipología claramente diferenciable del resto de la ciudad. Apuntando a convertir a Buenos Aires en la capital y procurando además el asiento permanente de sus organismos más representativos, o sea transformando la capital provisoria en una capital permanente.

Entre los objetivos particulares del presente trabajo analizados en el Capítulo II, referido al aspecto de las incorporaciones y/o modificaciones que el conjunto atravesó, se demuestra que la adición de la otra mitad de la manzana permitió sumar más metros cuadrados de uso del suelo, construyéndose un edificio idéntico al del proyecto original. Así también como otros que servirian de apoyo a este, lo que generó un crecimiento en el conjunto, sin embargo esto no alteró su armonía y unidad.

Por otro lado, queda evidenciado que la lectura de los volúmenes principales a la escala de la ciudad tampoco fue transfigurada.

También quedó demostrado en el desarrollo histórico del conjunto, que si bien al momento de su inauguración el destino fue modificado, rápidamente pudieron realizarse las adaptaciones edilicias correspondientes a su nuevo uso, sin que esto perjudicara la composición sus de envolventes, ni se viera alterada significativamente su distribución interior.

Además, se identificaron múltiples transformaciones a lo largo del tiempo, por situaciones ligadas a cambios políticos, sociales y/o culturales que afectaron al país y del cual el conjunto edilicio indefectiblemente no se mantuvo ajeno, pero a pesar de ello nunca perdió la consolidación que por entonces había alcanzado.

Retomando lo detallado en el Capítulo III, en la pregunta formulada sobre cúal fue el proceso de intervención que el conjunto ha atravesado, se pudo deducir que el mismo estuvo regido por distintos niveles de intervención.

A partir de la documentación consultada e incluída en la presente tesis, se concluye que la puesta en valor del bien, estuvo determinada por las siguientes tareas: el 
mantenimiento, la reparación, la rehabilitación, la restauración edilicia y la modernización de sus instalaciones.

Con estos objetivos como premisa y luego de un relevamiento exhaustivo de cada uno de los sectores componentes de los edificios, se establecieron sucesivas etapas de trabajo que permitieron obtener el conocimiento del bien en su totalidad y un ordenamiento de las labores a realizar. Se hizo imprescindible entonces unificar criterios para lograr una armonía entre las partes ya que se trataba de una tarea compleja desde todo punto de vista.

En la segunda parte del mismo capítulo, referido a la pregunta sobre cuáles fueron los logros obtenidos, se llega a la conclusión que fueron altamente satisfactorios, recuperando cada uno de los paramentos, devolviéndoles el esplendor que desde el momento de gestación habían tenido, sin que por ello perdieran su identidad.

Podría concluirse también que las tareas de puesta en valor, restauración y readecuación tecnológica del conjunto cumplieron con los principios internacionales establecidos en la mencionada Carta de Venecia ${ }^{41}$. Algunos de cuyos puntos se enumeran a continuación:

- La Restauración finaliza cuando comienza la hipótesis y es por ello la importancia del conocimiento del bien antes de su intervención.

- La salvaguardia del objeto y su significado, contempla al bien como un testimonio vivo de su historia, la cual se resignifica.

- La conservación del monumento implica primeramente la constancia en su mantenimiento. Dado que si no hay una observancia periódica del estado del bien es imposible su correcta preservación en el tiempo. En este punto resulta fundamental la documentación proporcionada por las empresas una vez concluidas las obras, ya que se convierten en testigo de los procedimientos realizados. Por otro lado los manuales de mantenimiento brindan la recomendaciones que deberán seguirse para sostener los resultados obtenidos en el tiempo.

\footnotetext{
${ }^{41}$ Carta de Venecia (Carta Internacional para la Conservación y la Restauración de Monumentos y sitios - II Congreso Internacional de Arquitectos y Técnicos de Monumentos Históricos) Venecia, Italia (1964). Artículos núm.3, 4 y 9 Arquitectónico. Hacia un Plan de Gestión”.
} 
Por último y en sintonía con lo descripto anteriormente, vale la pena mencionar que el trabajo realizado en el conjunto edilicio fue galardonado en el año 2015, con el 2do puesto en la categoría "Recuperación y Puesta en Valor", del premio mejores intervenciones en obras del casco histórico de Buenos Aires. ${ }^{42}$

En cuanto al Capítulo IV referido a cuáles son los deterioros y las patologías que se registraron en estos últimos años, la situación actual del conjunto y las medidas que deberían llevarse a cabo para revertir los desajustes encontrados, se hace evidente la necesidad de efectuar un relevamiento integral de cada sector de los edificios para evaluar los cambios o avances respecto al realizado un año atrás.

A partir de los resultados que se recojan se aconsejará intervenir sobre aquellas patologías y desajustes que requieran una pronta atención (ir de lo más grave a lo más leve, de lo general a lo particular). Dado que, si no se atacan tempranamente, la perdurabilidad de los mismos en el tiempo podría volverlos más graves y complejos de resolver. Se tomarán en cuenta las indicaciones de las empresas que trabajaron en el lugar, sumándo las observaciones que se realicen a partir del nuevo testeo.

En tal sentido resulta fundamental transmitir a las autoridades que tienen poder de decisión en el asunto que, aunque los trabajos pudieran representar un desembolso económico importante, se deberá tomar inmediata intervención, caso contrario los deterioros avanzarán en el tiempo, pudiendo demandar mayores costos.

A su vez se resaltará que siempre que sea posible las medidas que se adopten deberán ser reversibles, esto implica que se podrán eliminar y sustituir por otras más adecuadas y acordes a nuevos conocimientos que se vayan adquiriendo.

Asimismo se determinarán las características de los materiales, especialmente los nuevos que vayan a utilizarse, así como su compatibilidad con los existentes. Estudiando los impactos a largo plazo a fin de evitar efectos secundarios no deseables.

\footnotetext{
42 "Las mejores intervenciones en obras localizadas en el Casco Histórico de la Ciudad de Buenos Aires", iniciativa conjunta entre la Dirección General del Casco Histórico del Gobierno de la Ciudad y la Sociedad Central de Arquitectos, Bs.As. Edición 2015.
} 
Estos puntos se consideran importantes y se basan en los principios para el análisis, conservación y restauración de las estructuras arquitectónicas del año 2003. ${ }^{43}$

\section{CONCLUSIÓN FINAL}

Por lo anteriormente expuesto a lo largo de los capítulos y sumado a todas las fuentes documentales consultadas que componen el presente trabajo, se demuestra que el conjunto edilicio Ministerio de Agroindustria, posee un alto valor histórico, simbólico, social y cultural.

Es indispensable entonces, desarrollar un plan de gestión que asegure la correcta conservación del conjunto en el tiempo, valiéndose tanto de los mecanismos de difusión y comunicación interna, como de los instrumentos y acciones legales disponibles, el que debe contar con el respaldo de las máximas autoridades del Ministerio.

Entendiendo que todos los esfuerzos que se realicen en tal sentido, tienen que estar supervisados por un plantel de profesionales con expertise en temas patrimoniales dentro del organismo. Ya que la mirada permanente que estos especialistas puedan aportar mediante la realización de relevamientos e informes mensuales permitirá la detección temprana de deterioros y el planteo de las posibles pautas de trabajo. Esto, junto al seguimiento en la aplicación de los protocolos tanto en tareas de limpieza diaria como en los de empresas terciarizadas colaborará en la completa protección del bien.

Asimismo y teniendo en cuenta que localmente las cuestiones de índole patrimonial, siguen siendo materia de experimentación y aprendizaje, se requiere la reformulación de nuevos parámetros y legislación que logre establecer criterios de intervención que al momento carecen de regulación.

En síntesis, luego de la presentación de la tesis, se prevé continuar profundizando en los distintos aspectos de la investigación, entendiendo que será de vital importancia no

\footnotetext{
43 Principios para el análisis, conservación y restauración de las estructuras del patrimonio arquitectónico, ICOMOS (2003). Ratificada por la 14" Asamblea gral del ICOMOS, Victoria Falls, Zimbabwe, Octubre 2003(Ptos 3.9 y 3.10). 
sólo desde el punto de vista académico, sino que además generará una metodología que aporte información y toma de consciencia del valor del conjunto edilicio en cuestión.

Se seguirá avanzando en los puntos que se detallan a continuación, tomando como referencia la secuencia sugerida en este documento, contemplando la búsqueda de los recursos económicos necesarios para darles curso.

Por un lado se retomará un proyecto pensado tiempo atrás junto a la coordinadora del Programa Patrimonio Cultural del Ministerio de Agroindustria, Daniela Zattara, relativo a la edición de un libro que abarque aspectos relacionados con la historia del conjunto, el estudio de la evolución de la obra hasta la actualidad y la formulación de un plan para su mantenimiento preventivo.

Esta acción completará las publicaciones de catálogos que el Programa de Patrimonio Cultural realizó durante los años 2011 y 2013. En ambas oportunidades se editaron catálogos, los cuales fueron otorgados como obsequio a funcionarios nacionales y extranjeros invitados a diferentes eventos desarrollados en el organismo.

Cabe aclarar que hoy en día los catálogos continúan publicados en la página oficial del Ministerio, pudiendo ser descargados de allí para su lectura. ${ }^{44}$

Por otro lado, en la búsqueda de generar concientización en la sociedad, se solicitará la protección y salvaguardia del conjunto mediante el pedido formal de declaratoria del bien ante el Honorable Congreso de la Nación como Monumento Histórico Nacional, postulación formal que hasta la fecha había quedado trunca.

En tal sentido y en vías del reciente cambio de gestión, se recomendará a las nuevas autoridades que acompañen esta iniciativa ya que, aun cuando la presentación puede realizarla todo ciudadano común que así lo desee, el hecho de contar con el aval de los funcionarios entrantes podrá darle un mayor peso a la solicitud.

Esta declaratoria promoverá que la $\mathrm{CNMMLH}^{45}$ ejerza la custodia y conservación del bien en su máximo nivel de protección, ${ }^{46}$ en concordancia con las respectivas

\footnotetext{
${ }^{44}$ Equipo del programa de patrimonio cultural Ministerio de Agroindustria, año 2011 y 2013, Catálogos recuperados de http://www.minagri.gob.ar/sitio/areas/patrimonio/publicaciones/_archivos/Catalogo_artistico_2011.pdf

http://www.minagri.gob.ar/sitio/areas/patrimonio/publicaciones/_archivos/Catalogo_artistico_2013.pdf (07/12/2019)

45 (Ílem pie de página $N^{\circ} 18$ )

${ }^{46}$ Según lo mencionado anteriormente el conjunto edilicio posee actualmente una protección estructural integral.
} 
autoridades locales, brindando asesoría técnica en caso necesario. Además, contempla penas y multas por incumplimiento, estableciendo la obligación de restituir el bien a su estado original en caso de alteración de fachadas $u$ otras áreas comprendidas dentro de la máxima tutela edilicia.

Reiterando que el objetivo final de este documento es contribuir en la salvaguardia del conjunto, dada la complejidad de gestión que en general toda obra patrimonial posee a nivel local deficiente en políticas de memoria e identidad nacional. Por ello, se hace imprescindible llevarla a cabo desde una mirada multidisciplinaria en donde confluya la participación de todas las partes que interactúan en relacion al bien, esto es: el Estado, los investigadores, los profesionales, los especialistas en cada rubro, las empresas privadas contratadas y el público en general.

Para finalizar, se considera que las lineas de trabajo e intervenciones propuestas impactarán directamente en la visibilización del conjunto, con el fin de garantizar que pueda ser disfrutado por esta generación y las venideras.

En tal sentido, será fundamental que, cada una de las decisiones a tomar en el futuro, se ejecuten desde el conocimiento de las herramientas disponibles, acompañadas de un enfoque técnico adecuado, como medio para revalorizar la historia del conjunto edilicio y perpetuar su valor.

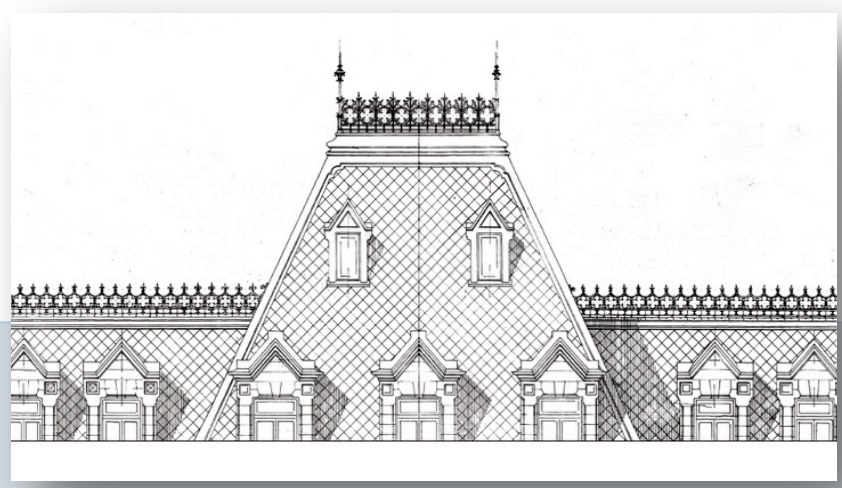




\section{FUENTES BIBLIOGRAFICAS}

\section{PROYECTOS Y MEMORIAS}

- "Proyecto de Asilo Nacional Nocturno para la Capital Federal" Ministerio de Obras Públicas, Dirección General de Arquitectura. Buenos Aires- Imprenta Cúneo, Año 1912.

- Memorias del Ministerio de Obras Públicas, presentadas al Honorable Congreso. Junio de 1912 a mayo 1913. Proyecto de Asilo Nacional Nocturno para la Capital Federal Talleres Gráficos del Ministerio de Obras públicas, Buenos Aires 1913 (pág. 61). (Biblioteca del Ministerio de Hacienda la de la Nación).

\section{CENTROS DE CONSULTA}

- CEDyAP (Centro de Documentación e investigación de la arquitectura pública- Material escrito, planos y fotografías históricas) AABE, C.A.B.A.- Argentina.

\section{LEYES Y DECRETOS VARIOS}

- Ley N²6.378 Convención sobre los derechos de las personas con Discapacidad y su protocolo Facultativo" (Buenos Aires - Sancionada el 21 /05/2008).

- Código de Edificación Protección contra incendios - medios de salida - ordenanza No45.4251 B.M. 19.287 (Publicada el 19/05/1992) y disposiciones complementarias.

- Decreto 1063/82 (de la Ley predecesora 12.668 y su modificatoria 27.103).

\section{$>$ CARTAS Y DOCUMENTOS INTERNACIONALES}

- Carta de Atenas para la restauración de Monumentos Históricos: Adoptada en la Primera Conferencia Internacional de Arquitectos y Técnicos de Monumentos Históricos, Atenas, (1931).

- Carta Internacional sobre la Conservación y la Restauración de los Monumentos y de los sitios de Venecia (1964).

- Principios para el análisis, conservación y restauración de las estructuras del patrimonio arquitectónico, ICOMOS (2003).

- INAH; "Carta de Taxco", Instituto Nacional de Antropología e Historia, México, 2009 "Antecedentes". 


\section{LIBROS}

- Liemur J. F. y Aliata F.(2004) "Diccionario de Arquitectura en la Argentina. Estilos obras bibliografias instituciones ciudades", e/h eclecticismo (pág. 8 a 13), Buenos Aires, Argentina, Clarin arquitectura, Buenos Aires Ed.

- Aliata, F. R., Carasatorre C.,Della Védova F., Garcia G.F.R., Iturria V., Ponce N.Sessa E.T., Tuler S., (2015) "Palacio del Congreso Nacional, Historia de su arquitectura"1ed. CABA, Editorial de la Imprenta del Congreso de la Nación Recuperado de internet https://issuu.com/frentemarchita/docs/libropalaciolegislativo-26x30-comp (01/05/20).

- Schmidt C., "Palacios sin Reyes. Edilicia Pública para la Capital Permanente". Buenos Aires 1880-1890. (Tesis doctoral 2004).

- Bozzano, J.N. "Palacio del Congreso de la Nación", Arias Incolla, M. de las Nieves(2012) "Cabildos, casas de gobierno y edificios públicos" (pág. 82 a 93) y Susini Burmester, C. "Palacio de Justicia. Templo ecléctico para los tribunales" (pág. 106 a 115).ed. literaria a cargo de Berto González Montaner. $1^{a}$ ed. Bs.As Arte Grafico Editorial. 168 p.:il.;28 x 22cm (Patrimonio argentino;5) ISBN 978-987-072094-2, 1.Patrimonio Cultural argentino.2. Patrimonio Arquitectónico. I.González Montaner, Berto, ed.lit.II Título. CDD 725.1 Fecha de catalogación 25/07/2012.

- Pellizzari de Hermitte, Amalia T. M (2013). "Teatro Colón. Historia de la construcción"(pág.60), Buenos Aires, Ed. De los Cuatro Vientos, (2013) ISBN: 978987-08-0820-6.

\section{> TRABAJOS PRÁCTICOS DE AUTORÍA PROPIA REALIZADOS PARA LA MAESTRIA CRIP}

- Trabajo práctico del Seminario Morfología Urbana Arquitectónica e Historia- Maestría CRIP - Universidad Nacional de La Plata - Profesores: Arqtos. Fabiana Carbonari y Sergio Gutarra. (Año 2017).

- Trabajo práctico del Seminario Patologías Constructivas y estructurales de la Maestría CRIP - Universidad Nacional de La Plata- Profesores: Scasso, Vicente, Gentile (Año 2015).

- Trabajo práctico del Seminario Proyecto de intervención I y II- Maestría CRIP Universidad Nacional de La Plata - Profesor: Arqto Fernando Gandolfi (Año 2017). 


\section{ARTÍCULOS DE REVISTAS Y ENSAYOS}

- "La Vuelta de Dos Palacios" de Sergio Kiernan - Suplemento M2 - Página 12 (26 de noviembre de 2011).

- El Siglo XIX en Argentina. Los orígenes del Neoclasicismo. Revista Nuestra Arquitectura.

- "El Ministerio de Agricultura", Revista Hábitat Conservación, Restauración \& Reciclaje (Número 73 Año XVIII).

- Inmigrantes y colonos en la provincia de Buenos Aires. Una mirada de largo plazo (siglos XIX-XXI). Nadia De Cristoforis, Editorial de la Facultad de Filosofía y Letras, UBA, abril de 2016.

- Creación y Producción en Diseño y Comunicación N²4 ISSN: 1668-5229. Ensayos sobre la imagen. Edición $V$ Trabajos de estudiantes de la Facultad de Diseño y Comunicación Año VI, Vol. 24, octubre 2009, Buenos Aires, Argentina |120 páginas.

- Guía del patrimonio cultural de Buenos Aires 1: edificios, sitios y paisajes. - 1a ed. Buenos Aires. Dirección General Patrimonio e Instituto Histórico.

- Eclecticismo en Argentina, Subjetivización del lenguaje. Ensayo para Historia III Cátedra Fernández -FADU-UBA http://enchinche.com/eclecticismo-en-argentina/ (27/04/2020).

\section{SITIOS WEB}

- https://www.cronista.com/general/193039-La-decada-infame-20080430-0007.html

- http://www.migraciones.gov.ar/accesible/indexN.php?hotel (26/04/2019)

- http://www.minagri.gob.ar/sitio/areas/patrimonio/videos/ (04/11/2019)

- https://www.danielschavelzon.com.ar/?cat=70 (10/05/2020) El Proyecto de Vittorio Meano para el Teatro Colón de Buenos Aires.

Portada: Tríptico correspondiente a la fachada de uno de los edificios principales del conjunto Realizado por el equipo del Programa de Patrimonio Cultural del Ministerio de Agroindustria.(Año 2011) 


\section{AGRADECIMIENTOS}

Me gustaría agradecer en estas líneas la ayuda que muchas personas y colegas me han prestado durante el proceso de investigación y redacción de este documento.

Merecen reconocimiento especial mis padres quienes con su esfuerzo y dedicación me brindaron una excelente educación, ayudándome a culminar mi carrera universitaria y en cada instancia de mi vida. Mi madre a quien extraño enormemente y mi padre que acompañó cada una de las etapas de mi formación apoyándome incondicionalmente y dándome el amor necesario para no decaer cuando todo parecía complicado e imposible.

A mi hijo a quien amo profundamente. Asimismo, agradezco infinitamente al resto de mi familia ya que todos son una parte fundamental de mi camino.

A mis amigos que alegran mi existencia con su compañía.

A las autoridades del Ministerio de Agroindustria, los equipos de los cuales he formado parte y quienes anónimamente o no, aportaron su granito de arena, especialmente a Daniela Zattara por la confianza y los años de trabajo juntas.

Al arquitecto magister Marcelo Magadán, quien facilitó gran parte del material de esta tesis y es pieza fundamental en este recorrido. Él no solo ha guiado parte de mi carrera laboral, sino que además es un referente invaluable para mí profesionalmente y por su calidad humana.

A la Universidad Nacional de la Plata, sus directivos y docentes, por ser la sede de todo el conocimiento adquirido en estos años de maestría, permitiéndome profundizar en el campo de la conservación, restauración, e intervención del patrimonio arquitectónico y urbano.

Finalmente quiero expresar mi más sincero agradecimiento al Director de la Tesis, el especialista arquitecto Sergio Gutarra, principal colaborador durante todo este proceso ya que sus aportes enriquecieron y ayudaron en gran medida al desarrollo de esta presentación. 


\section{ANEXO PLANOS Y FOTOGRAFÍAS}

Procesados y digitalizados por el CeDIAP 

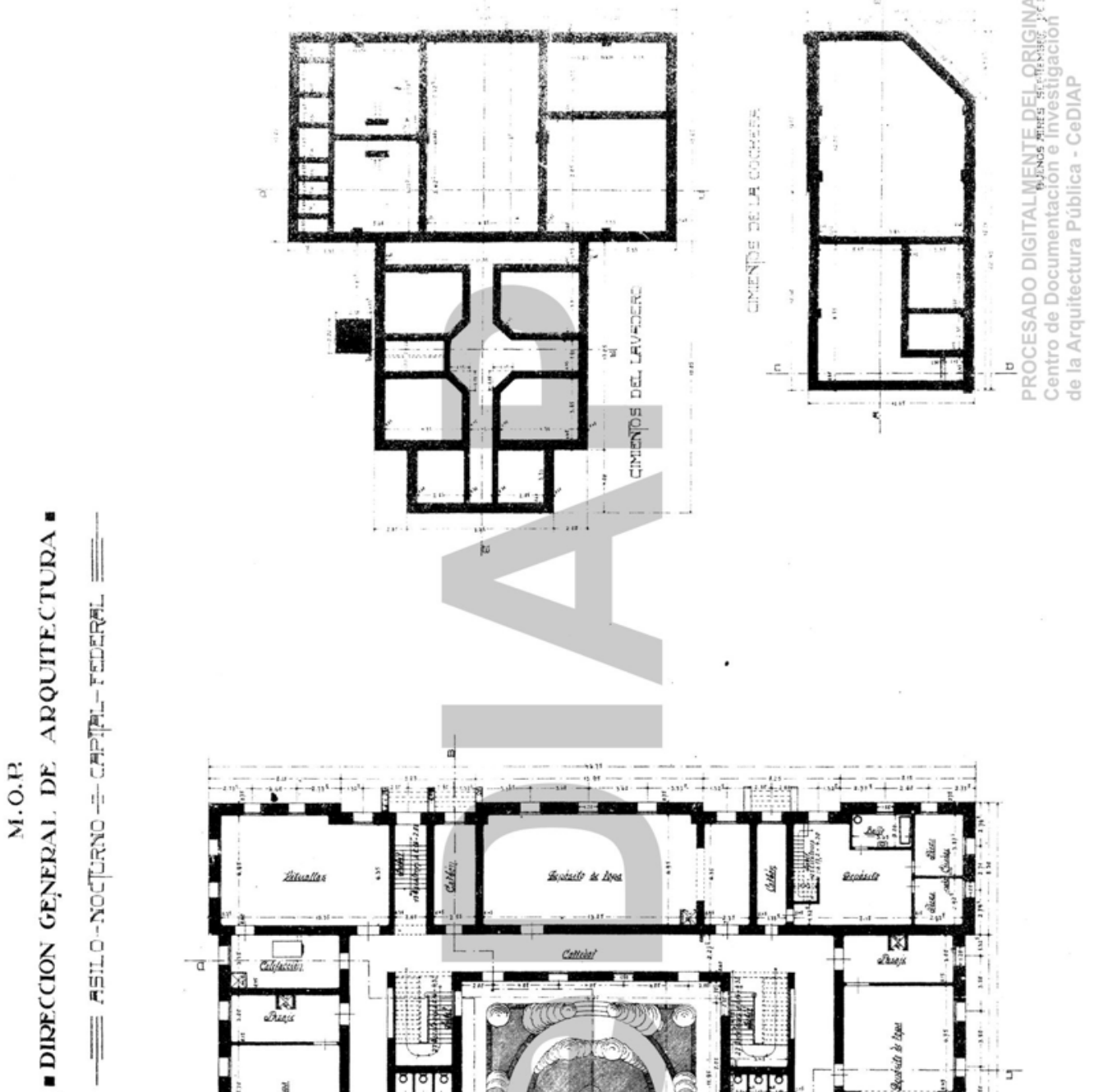

Fig. No 1.- PLANO DE EDIFICIO PPAL. SOTANO Y PTA DE CIMIENTOS COCHERA Y LAVADERO

Conjunto Edilicio Ministerio de Agroindustria de la Nación (ex Asilo Nocturno de la Capital) "Desarrollo de los instrumentos para la Conservación e Intervención del Patrimonio Arquitectónico. Hacia un Plan de Gestión". 
FACULTAD DE ARQUITECTURA Y URBANISMO - UNIVERSIDAD NACIONAL DE LA PLATA MAESTRÍA EN CONSERVACIÓN, RESTAURACIÓN E INTERVENCIÓN DEL PATRIMONIO ARQUITECTÓNICO Y URBANO (CRIP - FAU / UNLP)

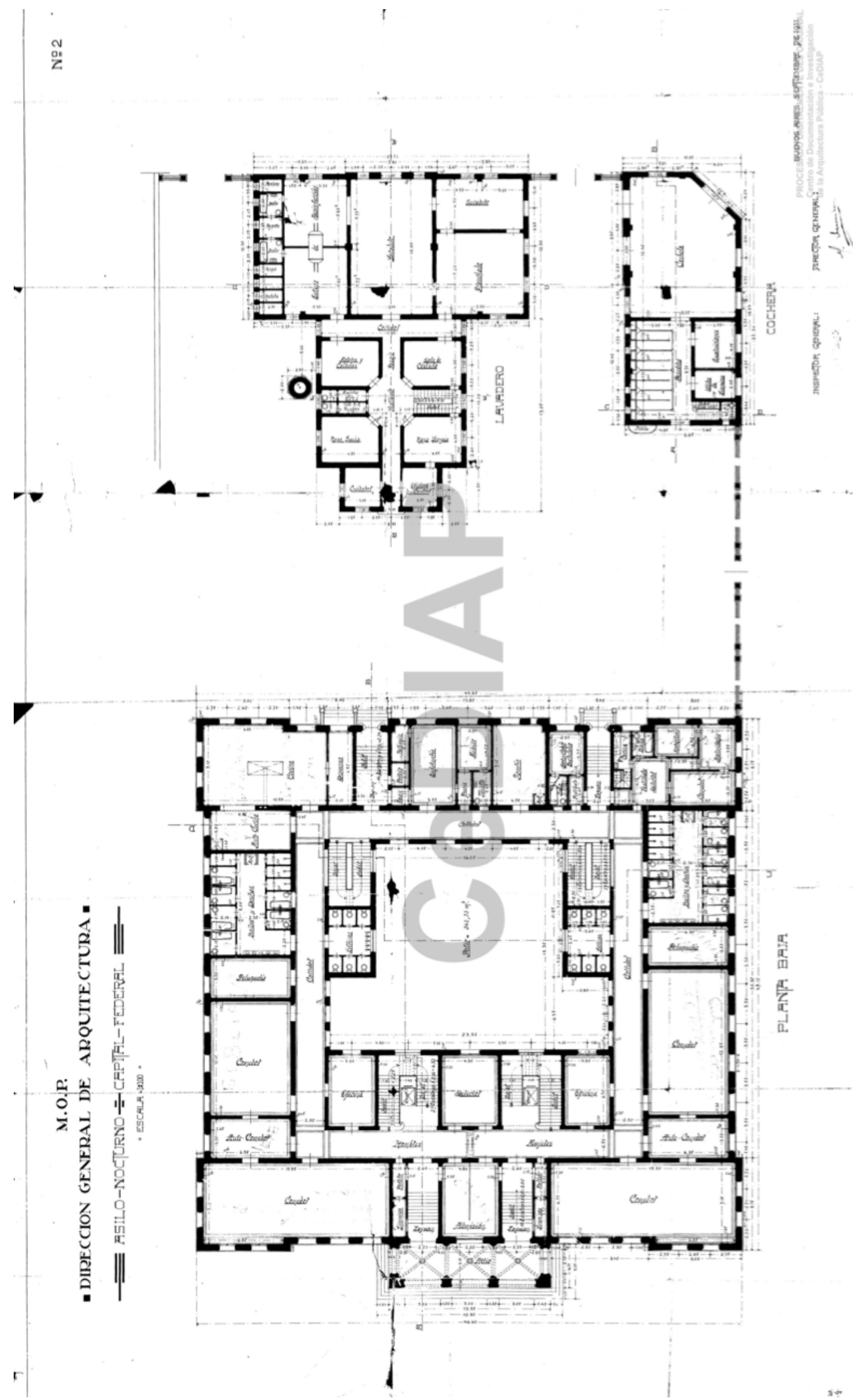

Fig. N².- PLANO EDIFICIO PPAL. LAVADERO Y COCHERA P.B. 


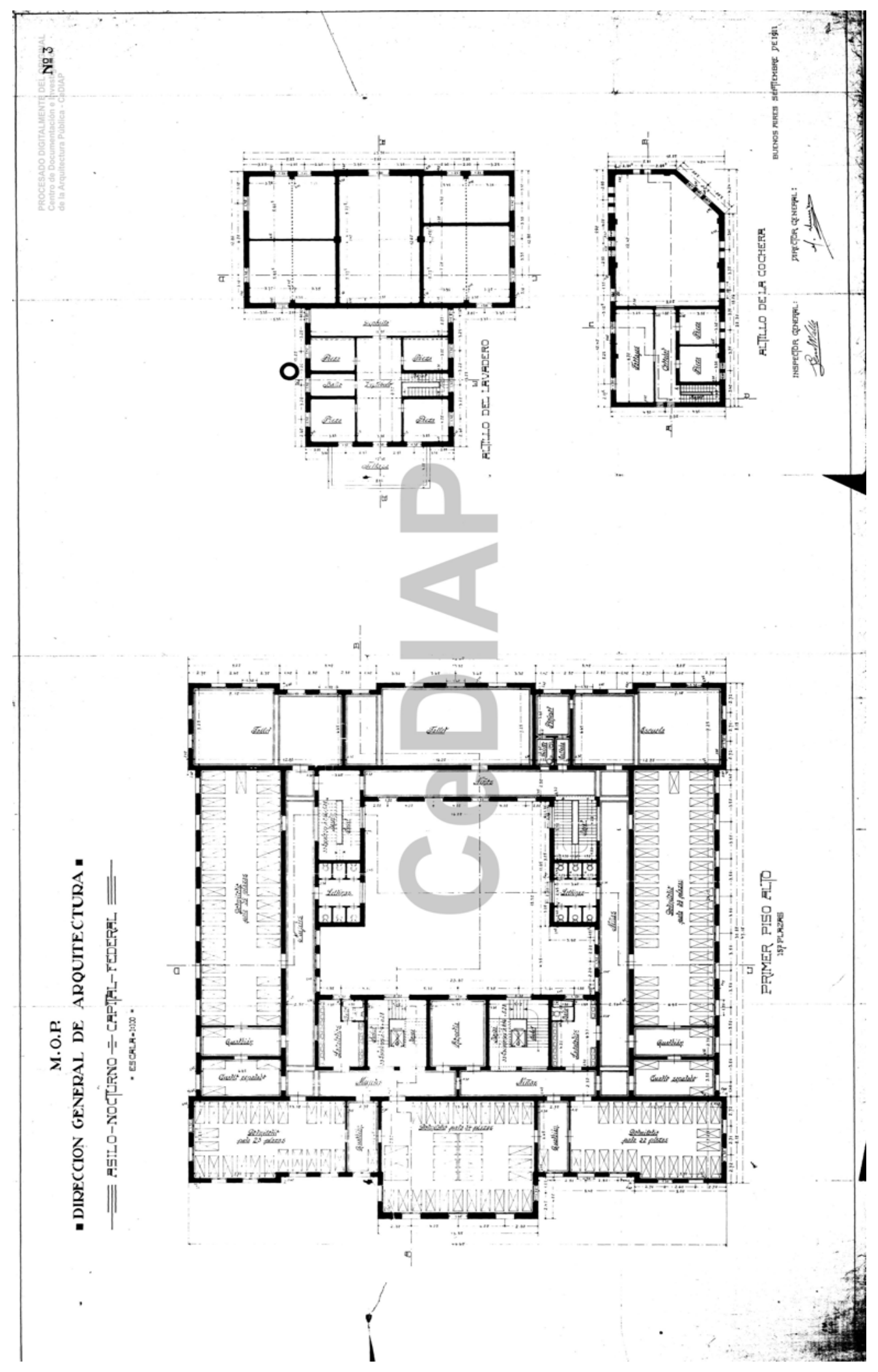

Fig.Nㅇ․- PLANO EDIF. PPAL. LAVADERO Y COCH. P. A.

Conjunto Edilicio Ministerio de Agroindustria de la Nación (ex Asilo Nocturno de la Capital) "Desarrollo de los instrumentos para la Conservación e Intervención del Patrimonio Arquitectónico. Hacia un Plan de Gestión". 
FACULTAD DE ARQUITECTURA Y URBANISMO - UNIVERSIDAD NACIONAL DE LA PLATA MAESTRÍA EN CONSERVACIÓN, RESTAURACIÓN E INTERVENCIÓN DEL PATRIMONIO ARQUITECTÓNICO Y URBANO (CRIP - FAU / UNLP)

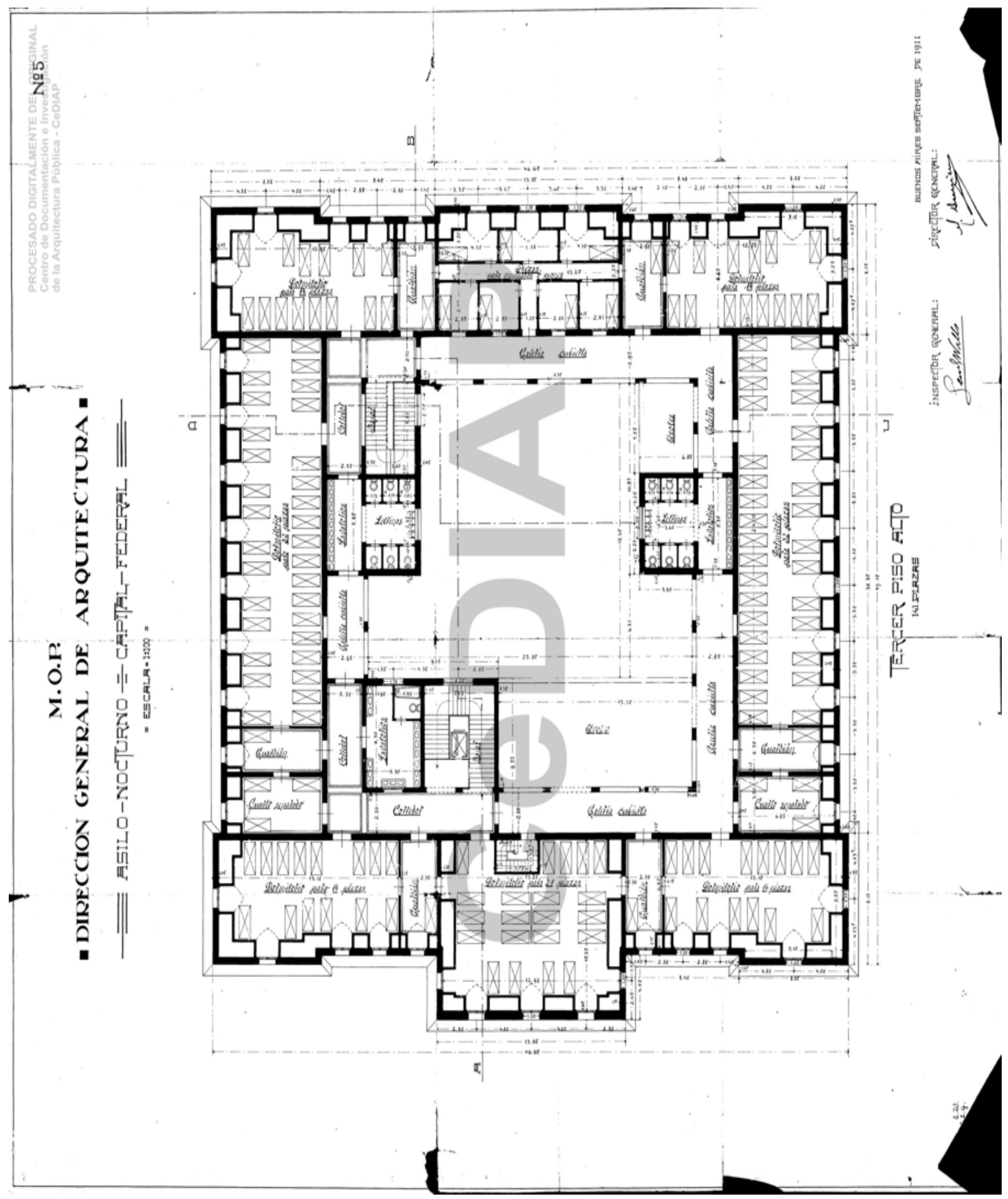

Fig. No 4.- PLANO EDIFICIO PRINCIPA, PLANTA $2^{\circ}$ PISO ALTO. LAVADERO Y COCHERA 


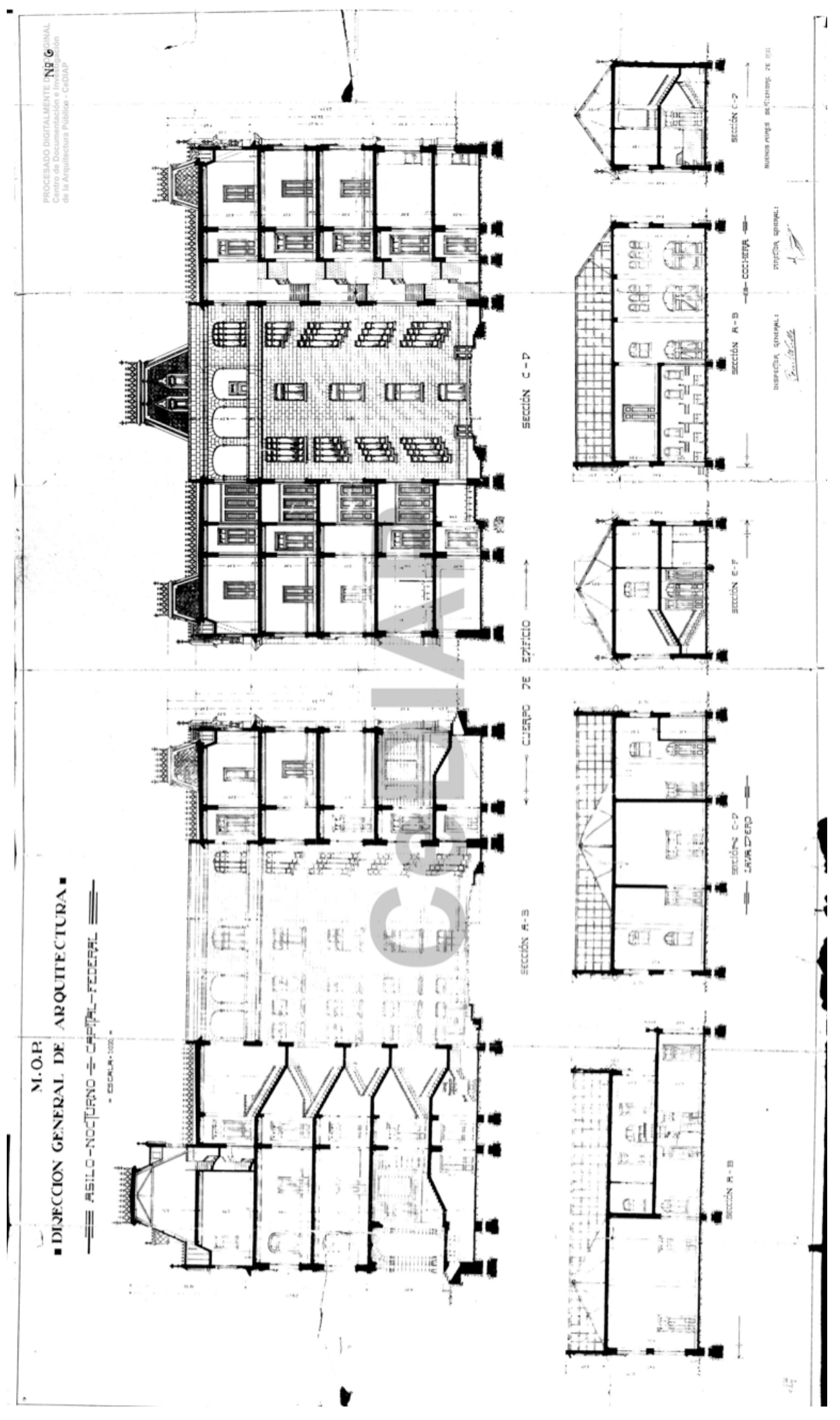

Fig. $N^{\circ}$ 5.- PLANO DE CORTES EDIFICIO PPAL, LAVADERO Y COCHERA

Conjunto Edilicio Ministerio de Agroindustria de la Nación (ex Asilo Nocturno de la Capital) "Desarrollo de los instrumentos para la Conservación e Intervención del Patrimonio Arquitectónico. Hacia un Plan de Gestión". 


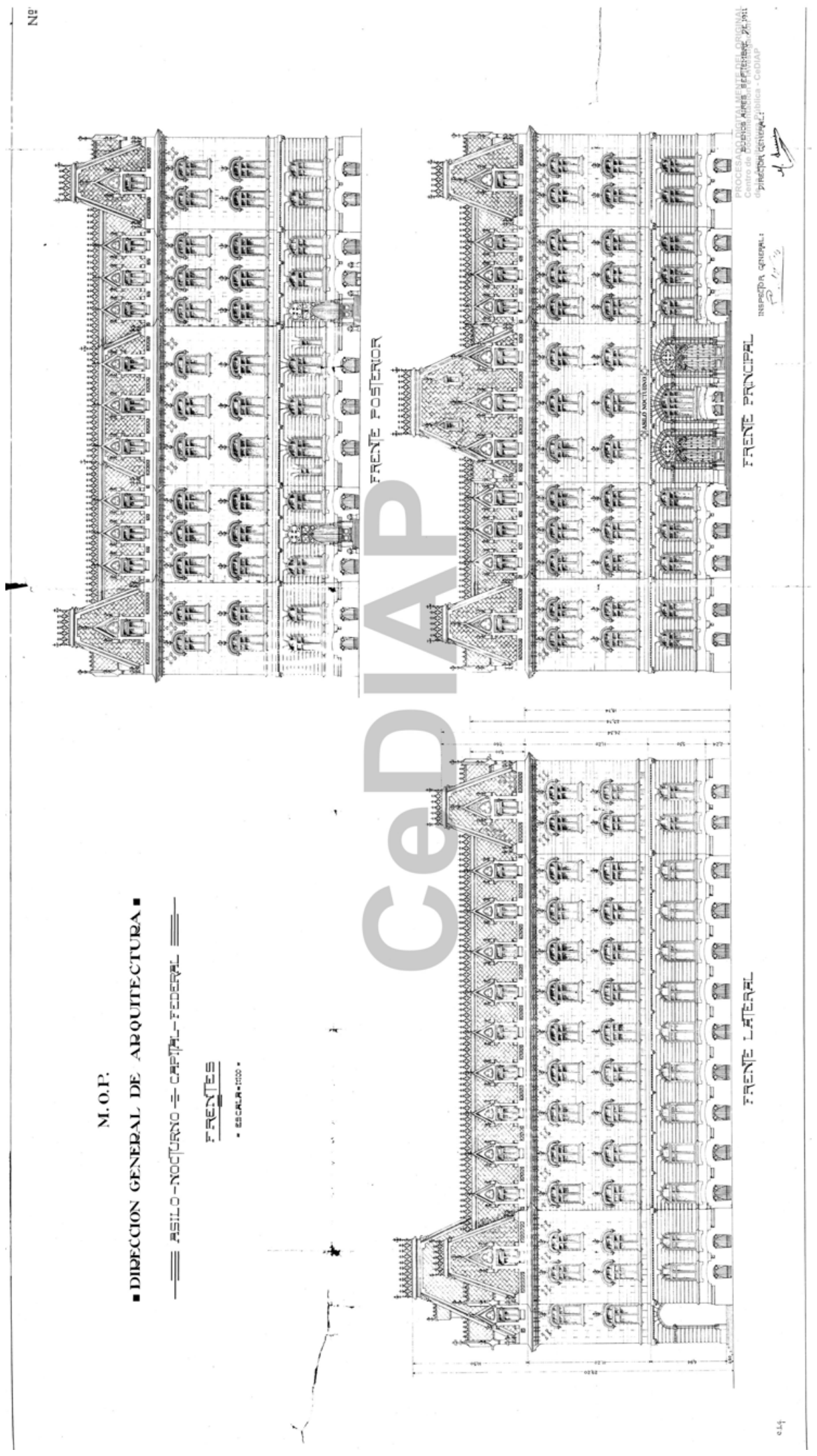

Fig. NN 6.- PLANO DE EDIFICIO PRINCIPAL FRENTES 


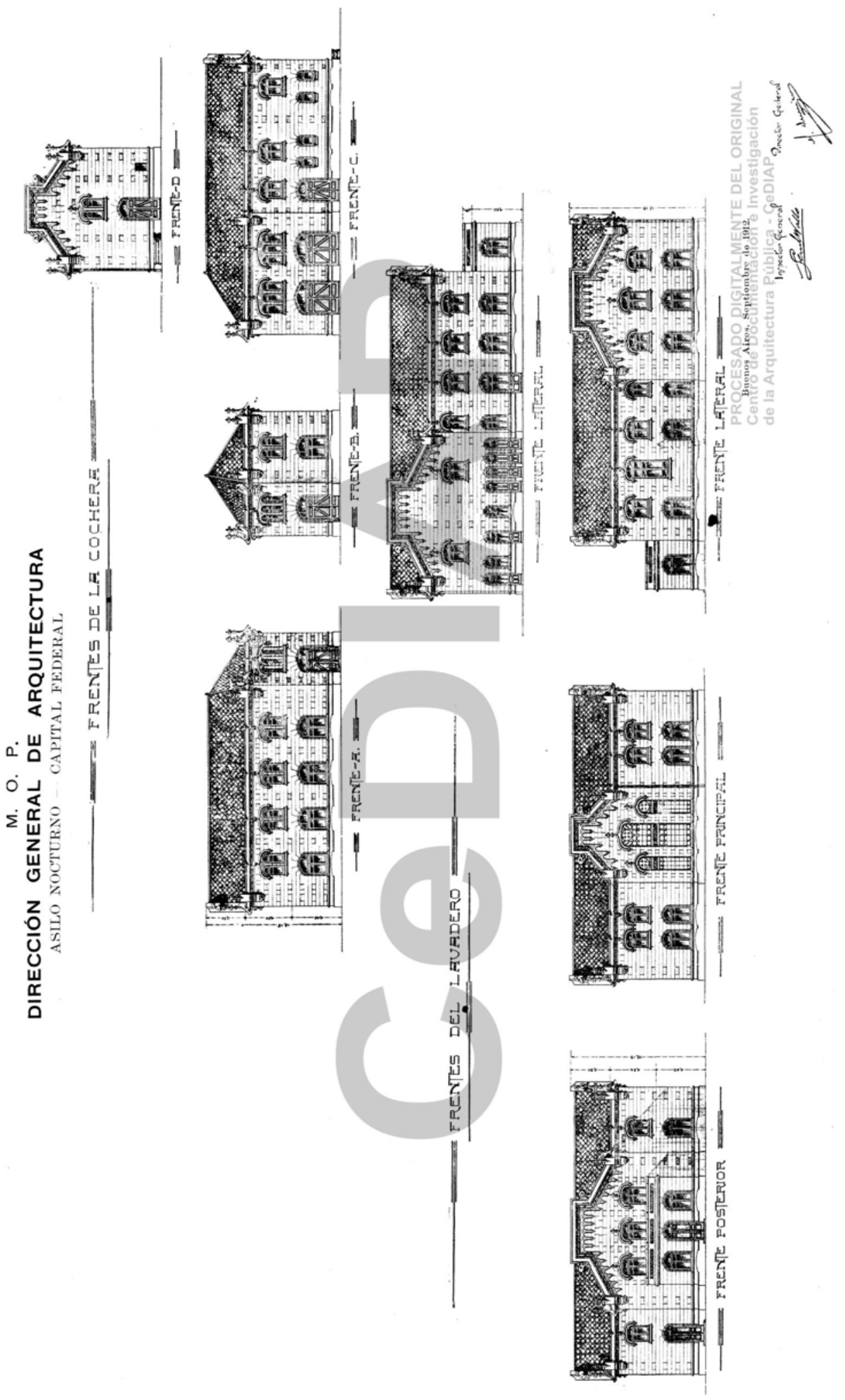

Fig. $N^{\circ}$ 7.- PLANO DE FRENTES LAVADERO Y COCHERAS

Conjunto Edilicio Ministerio de Agroindustria de la Nación (ex Asilo Nocturno de la Capital) "Desarrollo de los instrumentos para la Conservación e Intervención del Patrimonio Arquitectónico. Hacia un Plan de Gestión". 




Fig. No 8.- PLANO DE CIMIENTOS - PLANTAS Y SECCIONES 


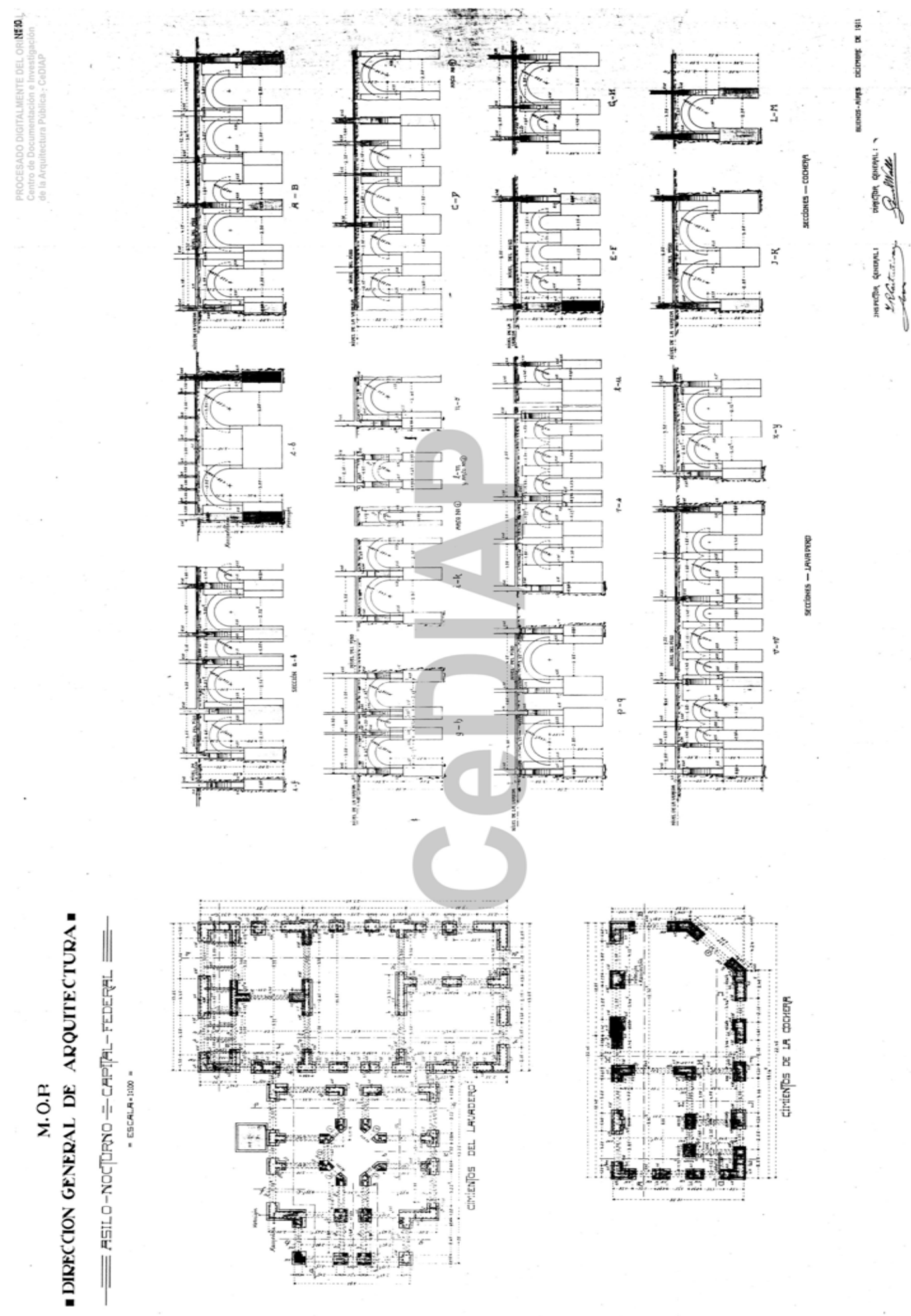

Fig. No 9.- PLANO DE CIMIENTOS, PLANTAS Y SECCIONES DE LAVADERO / COCHERAS

Conjunto Edilicio Ministerio de Agroindustria de la Nación (ex Asilo Nocturno de la Capital) "Desarrollo de los instrumentos para la Conservación e Intervención del Patrimonio Arquitectónico. Hacia un Plan de Gestión". 
FACULTAD DE ARQUITECTURA Y URBANISMO - UNIVERSIDAD NACIONAL DE LA PLATA

MAESTRÍA EN CONSERVACIÓN, RESTAURACIÓN E INTERVENCIÓN DEL PATRIMONIO ARQUITECTÓNICO Y URBANO (CRIP - FAU / UNLP)

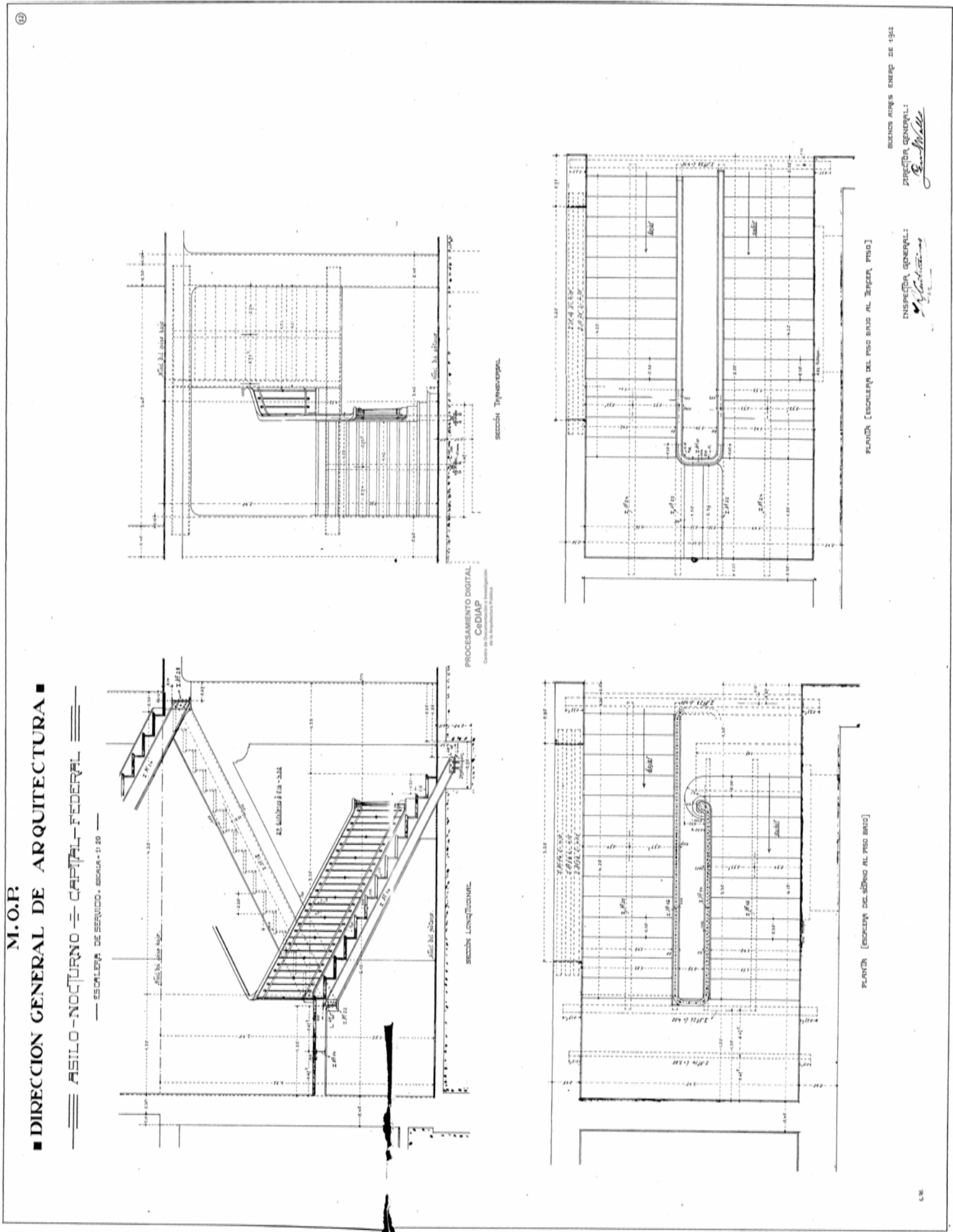

Fig. No 10.- PLANTA Y CORTES ESCALERA DE SERVICIO EDIFICIO PRINCIPAL 
M.O.P

(19)

- DIRECCION GENERAL DE ARQUITECTURA.

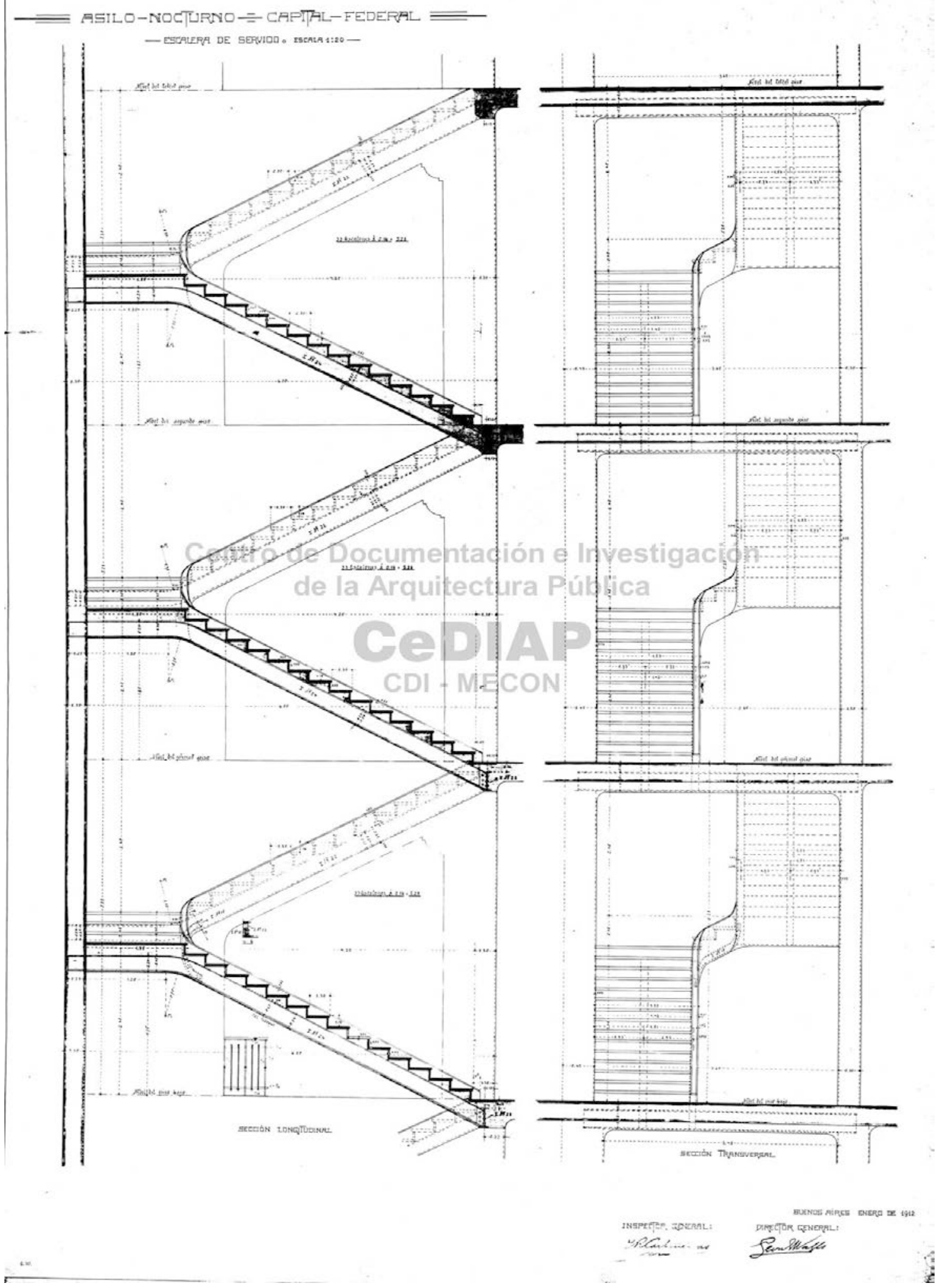

Fig. No 11.- PLANO ESCALERA DE SERVICIO EDIFICIO PRINCIPAL CORTES

Conjunto Edilicio Ministerio de Agroindustria de la Nación (ex Asilo Nocturno de la Capital)

"Desarrollo de los instrumentos para la Conservación e Intervención del Patrimonio Arquitectónico. Hacia un Plan de Gestión”. 

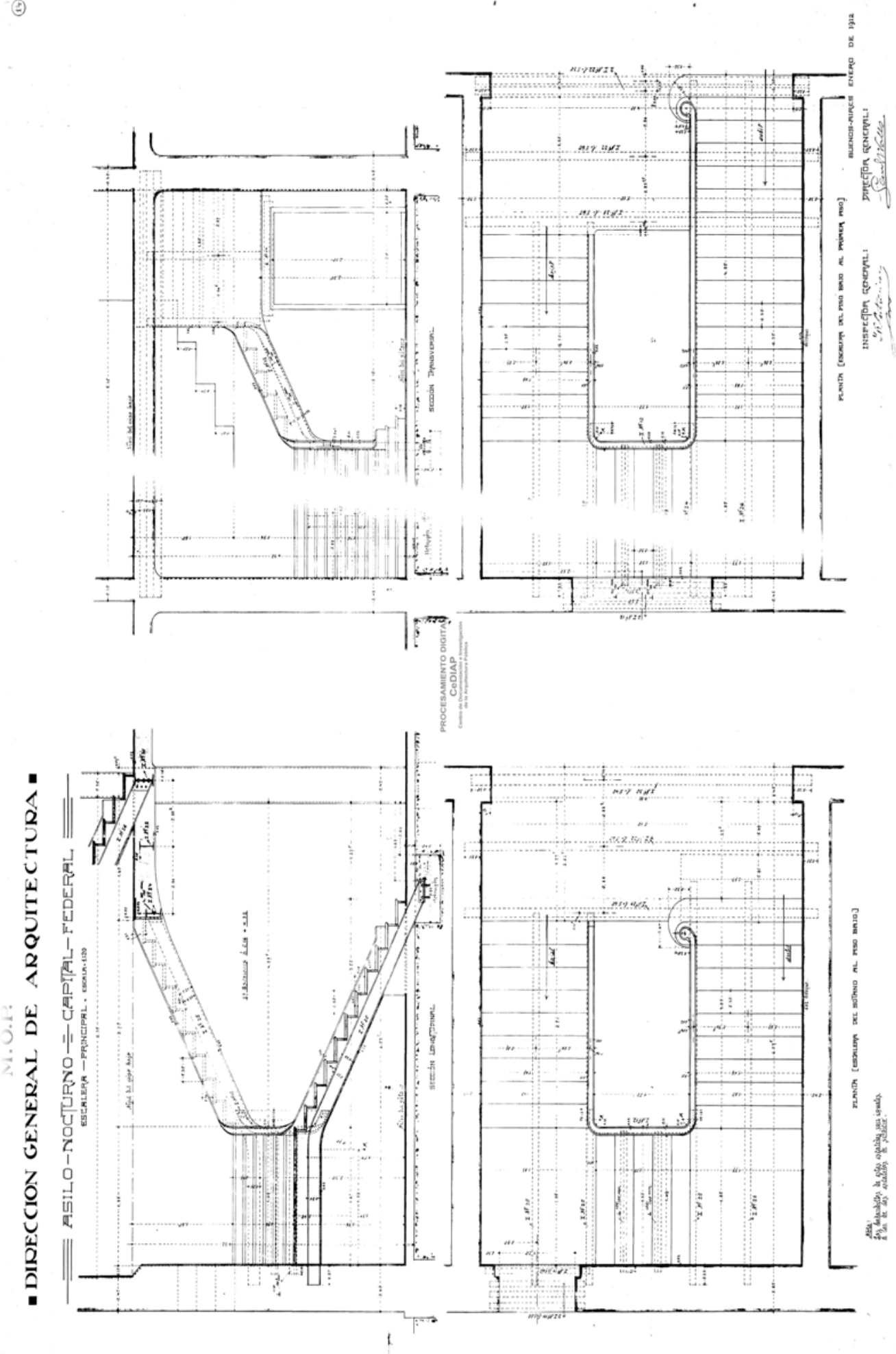

Fig No 12.- PLANO ESCALERA EDIFICIO PRINCIPAL - PLANTAS Y CORTES 
(오
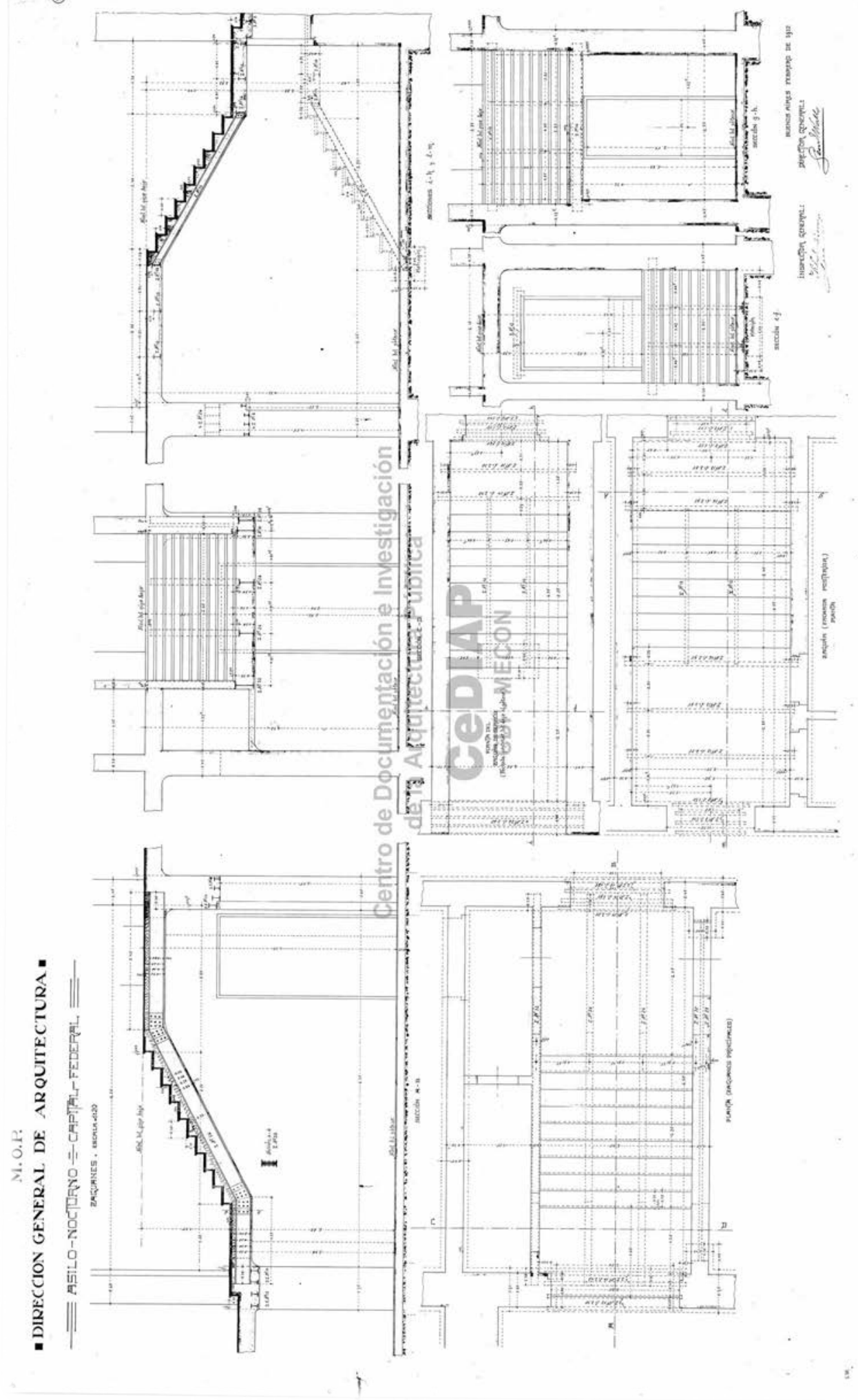

Fig. No 13.- PLANO EDIFICIO PRINCIPAL ZAGUANES

Conjunto Edilicio Ministerio de Agroindustria de la Nación (ex Asilo Nocturno de la Capital) "Desarrollo de los instrumentos para la Conservación e Intervención del Patrimonio Arquitectónico. Hacia un Plan de Gestión". 
FACULTAD DE ARQUITECTURA Y URBANISMO - UNIVERSIDAD NACIONAL DE LA PLATA MAESTRÍA EN CONSERVACIÓN, RESTAURACIÓN E INTERVENCIÓN DEL PATRIMONIO ARQUITECTÓNICO Y URBANO (CRIP - FAU / UNLP)

(-)
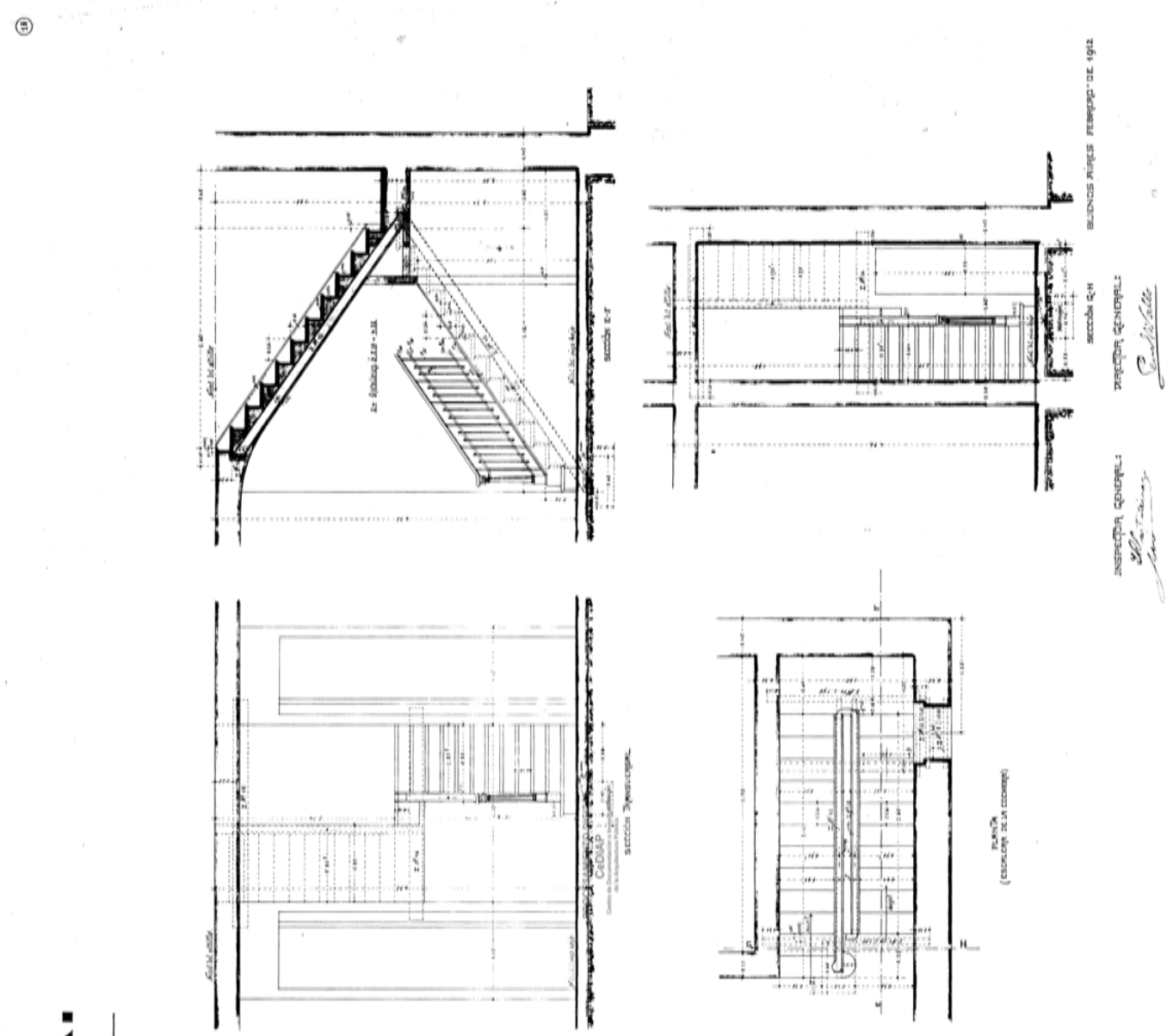

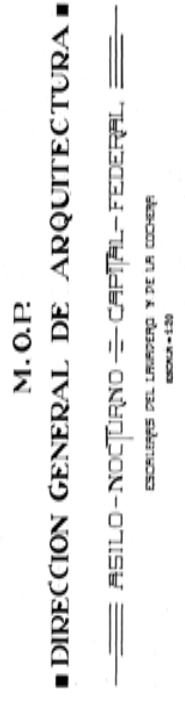

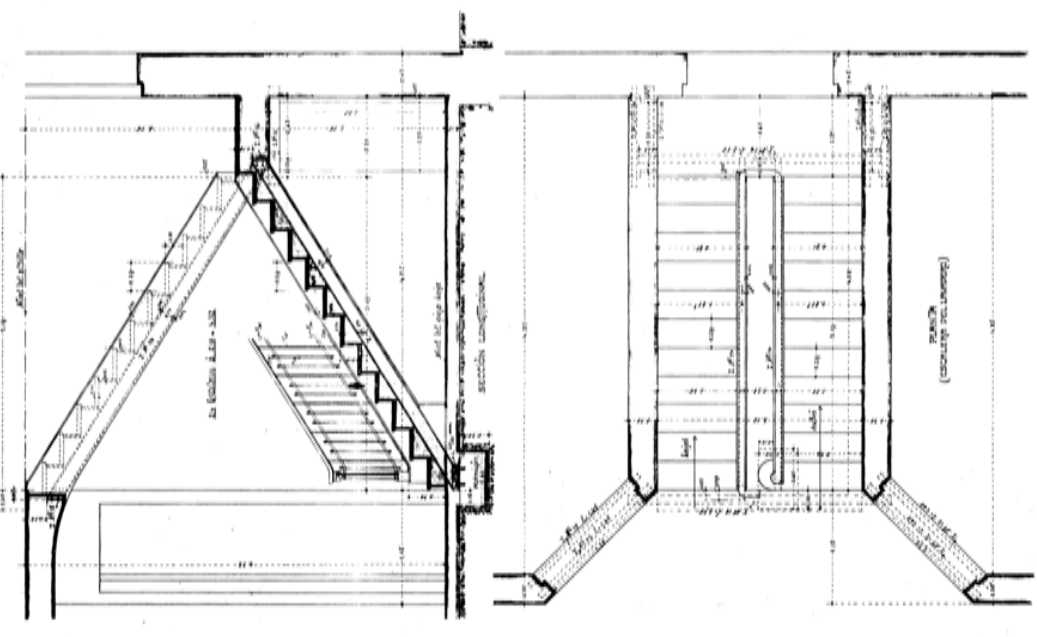

Fig. No 14.- PLANO DE ESCALERA SECTOR LAVADERO Y COCHERA 
(2)

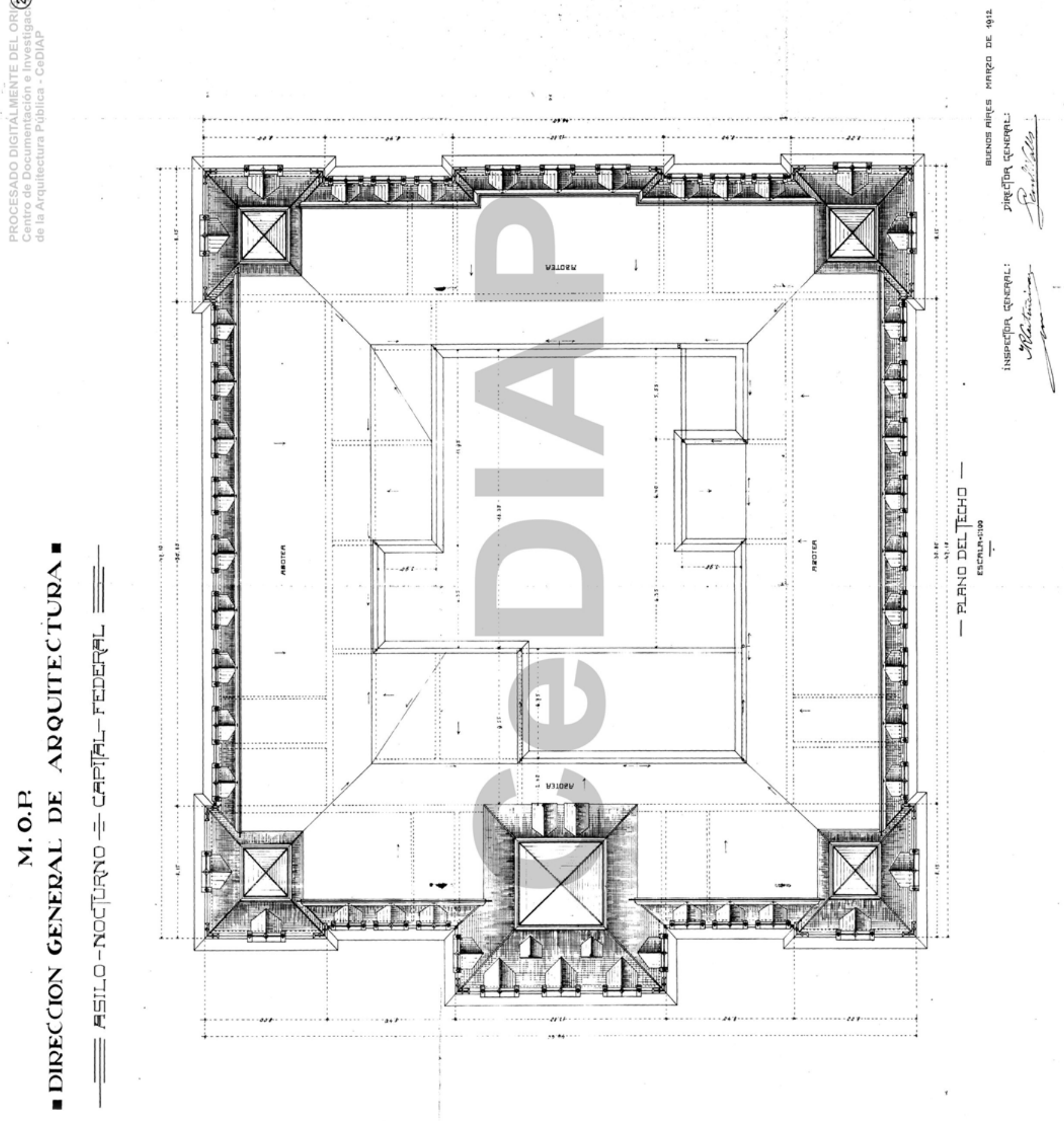

Fig. No 15.- EDIFICIO PPAL. PLANTA DE TECHO

Conjunto Edilicio Ministerio de Agroindustria de la Nación (ex Asilo Nocturno de la Capital) "Desarrollo de los instrumentos para la Conservación e Intervención del Patrimonio Arquitectónico. Hacia un Plan de Gestión". 
FACULTAD DE ARQUITECTURA Y URBANISMO - UNIVERSIDAD NACIONAL DE LA PLATA

MAESTRÍA EN CONSERVACIÓN, RESTAURACIÓN E INTERVENCIÓN DEL PATRIMONIO ARQUITECTÓNICO Y URBANO (CRIP - FAU / UNLP)
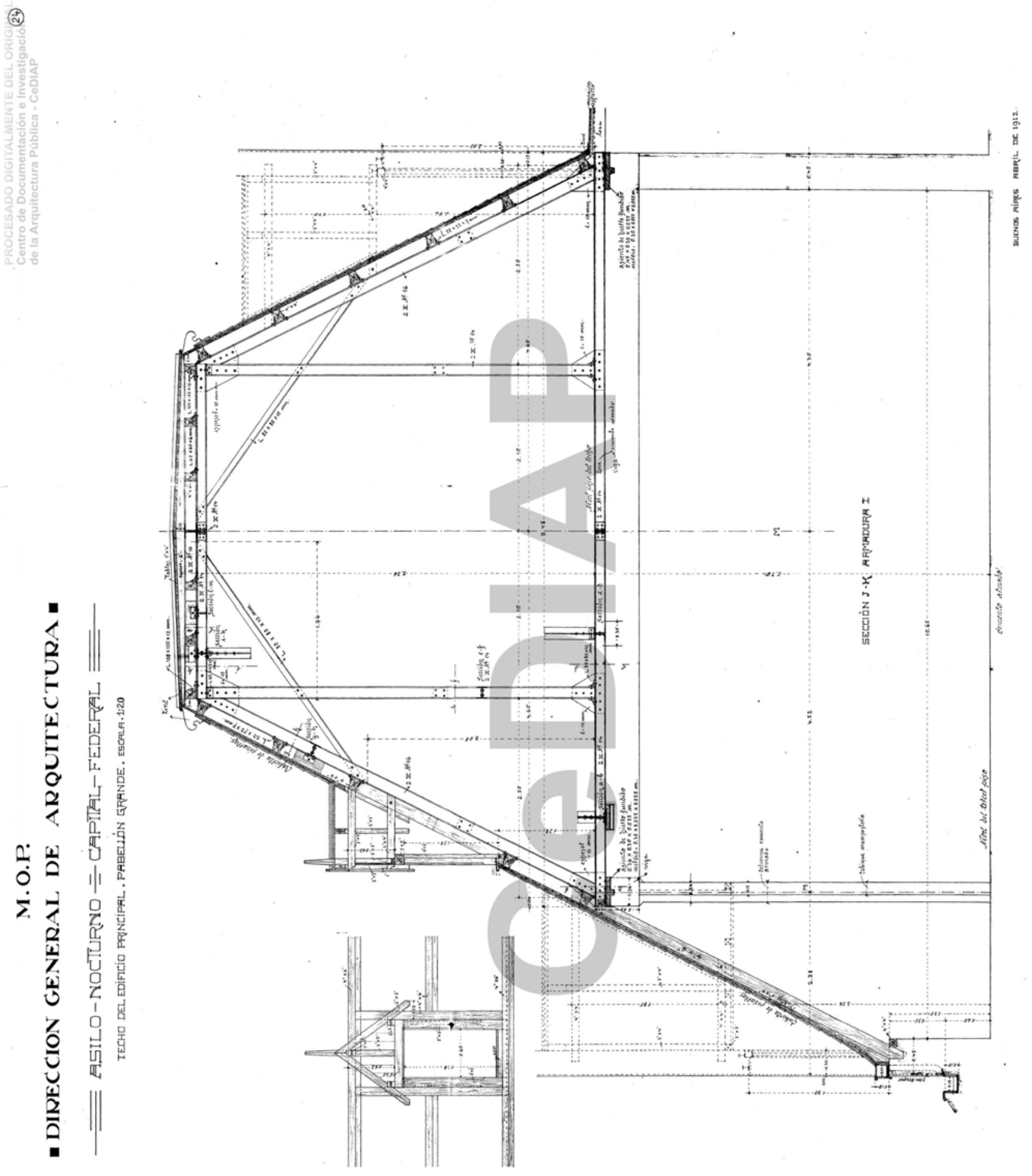

Fig. No 16.- CORTE EDIFICIO PPAL. PABELLÓN GRANDE. 


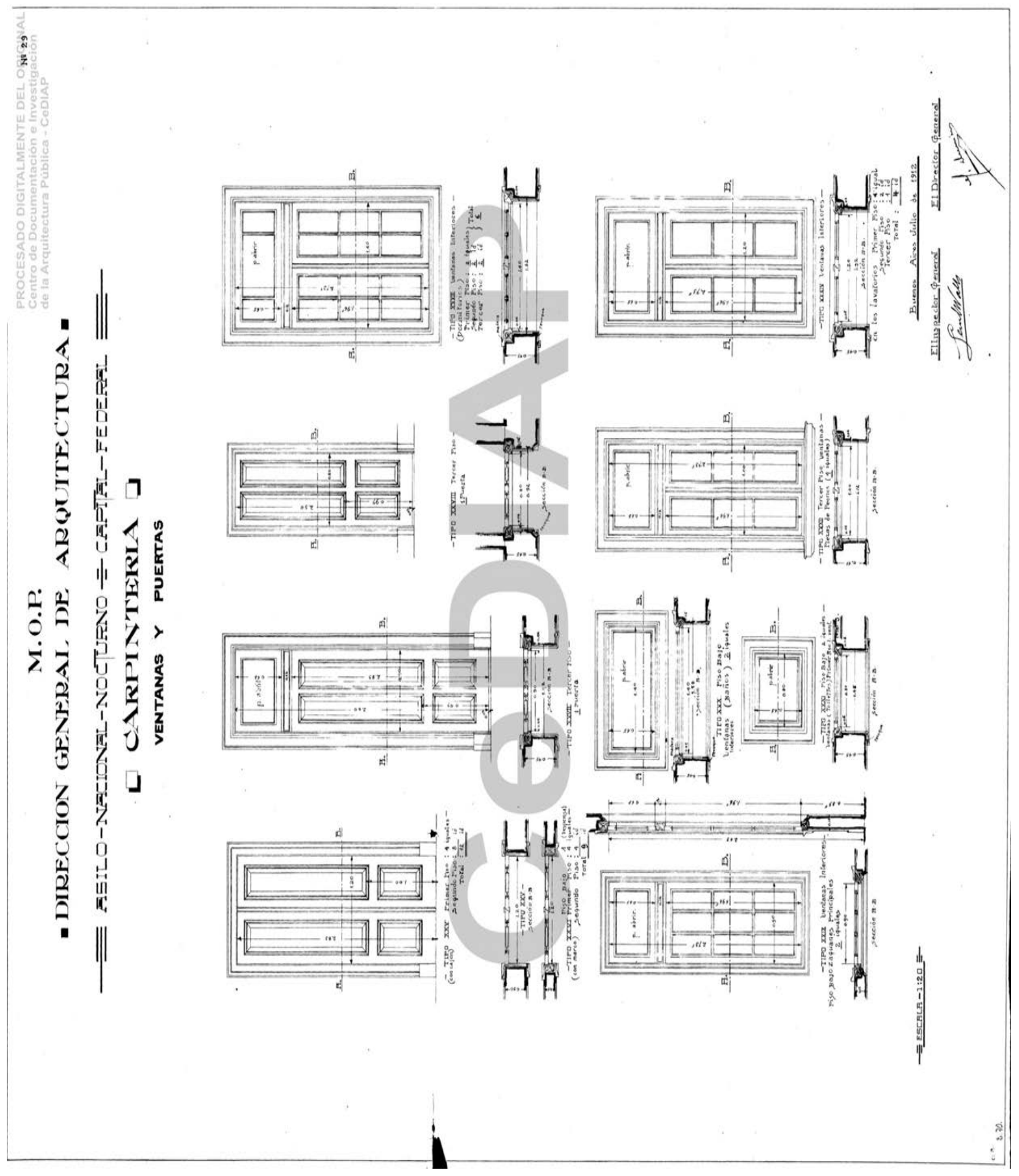

Fig.N N 17.- EDIFICIO PRINCIPAL CARPINTERÍA - VENTANAS Y PUERTAS

Conjunto Edilicio Ministerio de Agroindustria de la Nación (ex Asilo Nocturno de la Capital) "Desarrollo de los instrumentos para la Conservación e Intervención del Patrimonio Arquitectónico. Hacia un Plan de Gestión". 
M.O.P.

- DIRECCION GENERAL DE ARQUTTECTURA D

= MSILQ-NECIONML-NOLTURNO ニ CMPTRL-FEDEREL $\bar{~}$

L CARPINTERIA

PUERTAS = ESCPLA 1:20

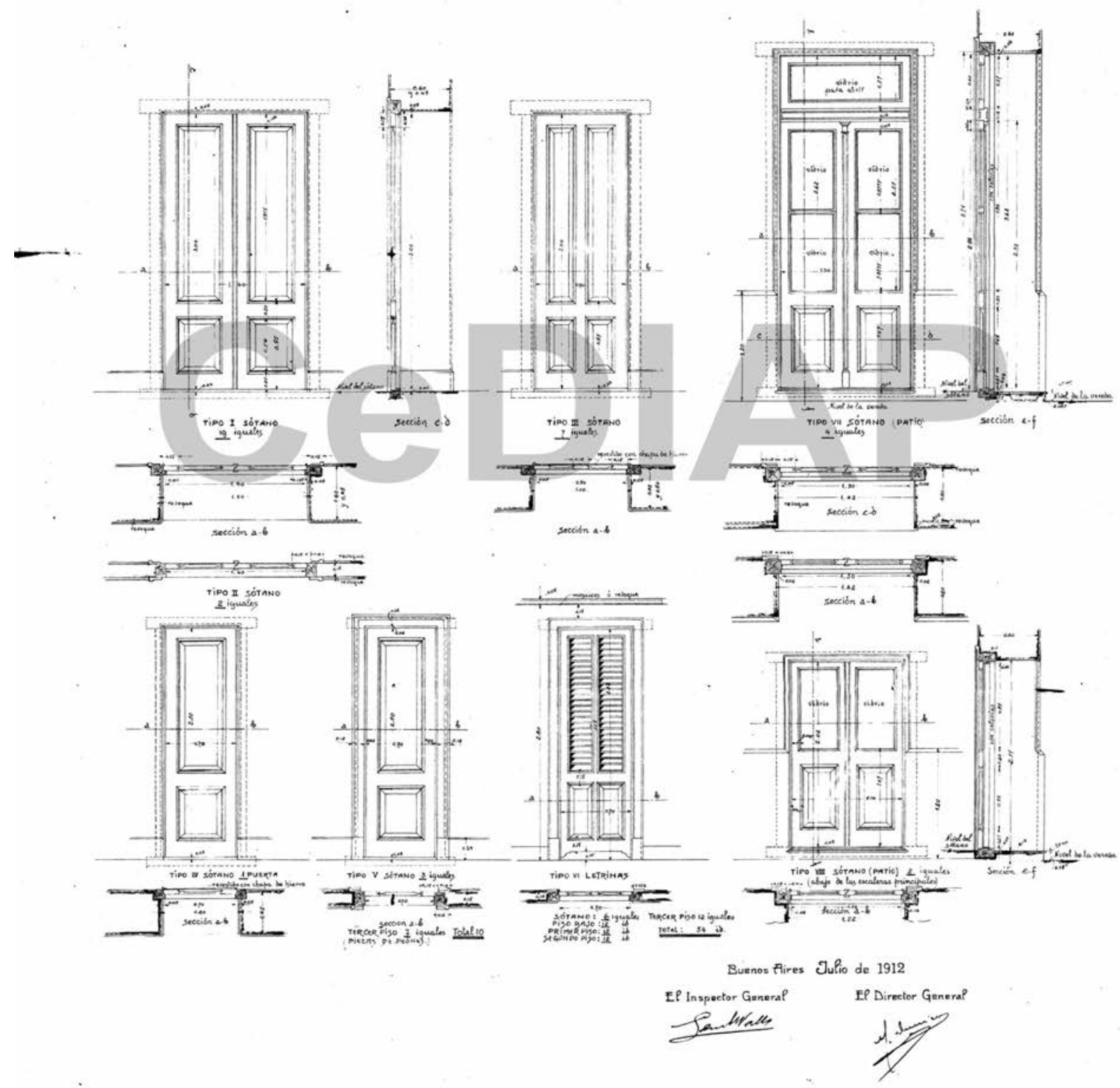

Fig. No 18.- DETALLE EDIFICIO PRINCIPAL CARPINTERÍAS 

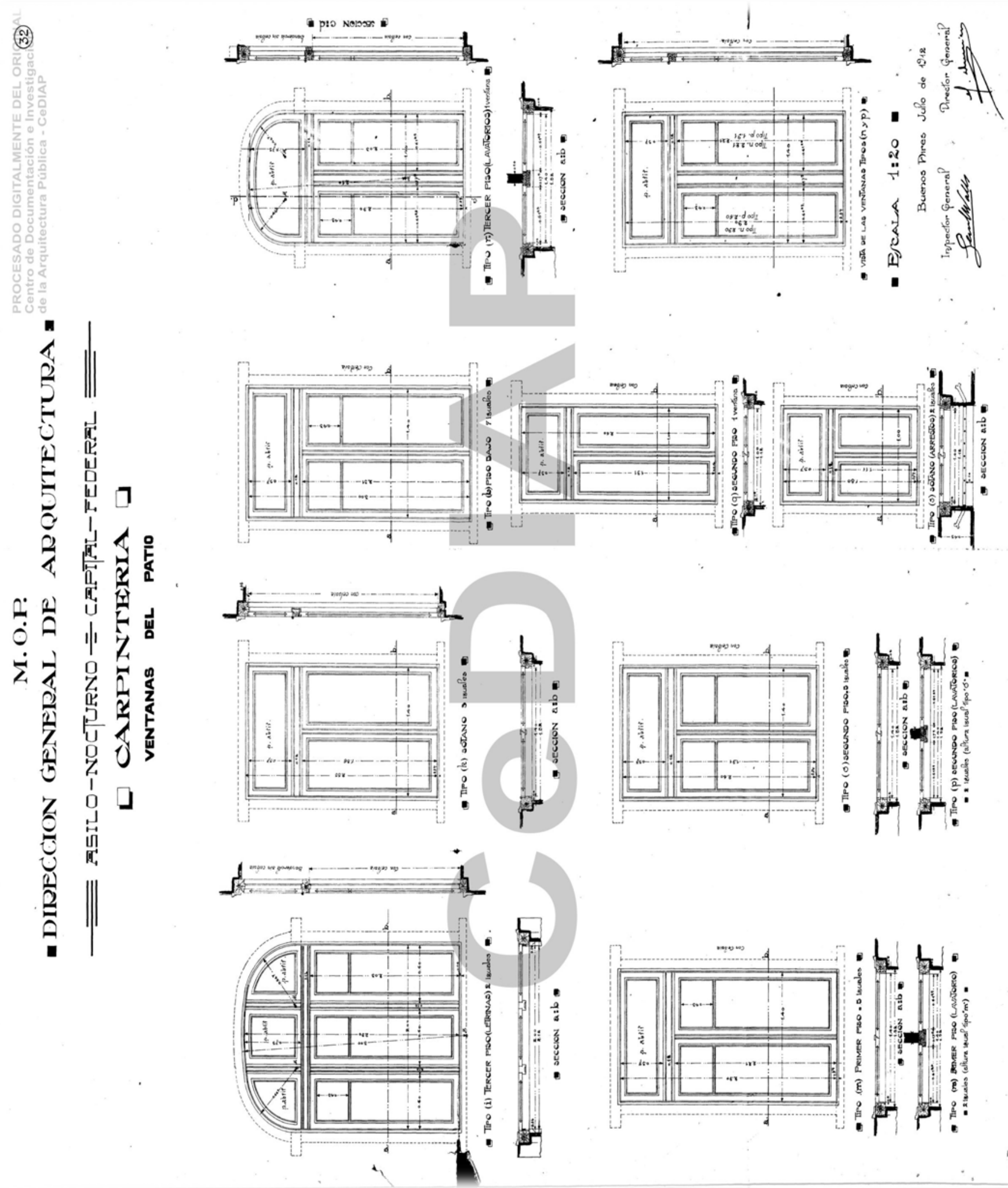

Fig. No 19.- DETALLE CARPINTERIASS EDIFICIO PRINCIPAL - PATIO

Conjunto Edilicio Ministerio de Agroindustria de la Nación (ex Asilo Nocturno de la Capital) "Desarrollo de los instrumentos para la Conservación e Intervención del Patrimonio Arquitectónico. Hacia un Plan de Gestión". 
FACULTAD DE ARQUITECTURA Y URBANISMO - UNIVERSIDAD NACIONAL DE LA PLATA

MAESTRÍA EN CONSERVACIÓN, RESTAURACIÓN E INTERVENCIÓN DEL PATRIMONIO ARQUITECTÓNICO

Y URBANO (CRIP - FAU / UNLP)

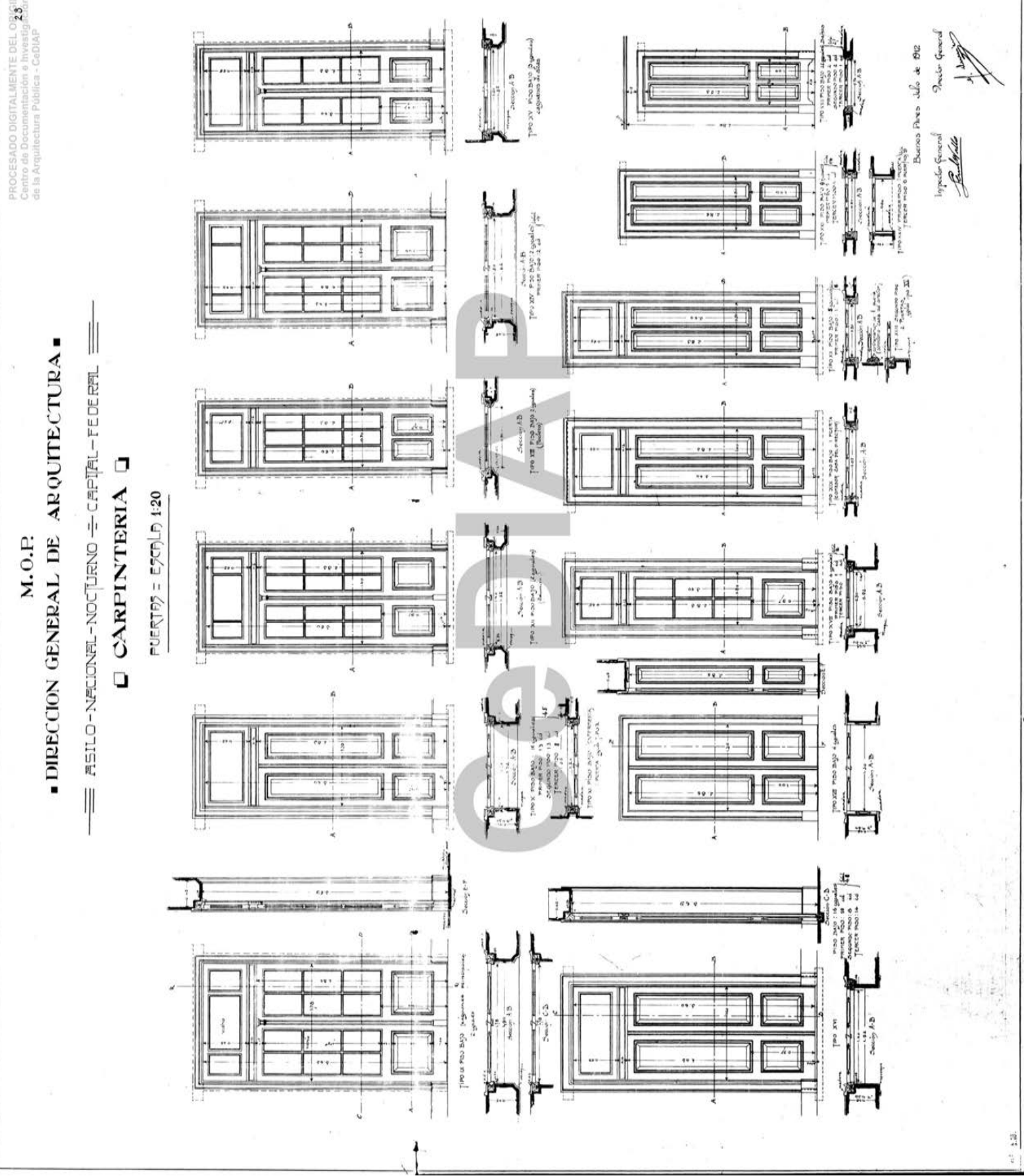

Fig. N ${ }^{\circ}$ 20.- DETALLE LAVADERO Y COCHERA CARPINTERÍAS 


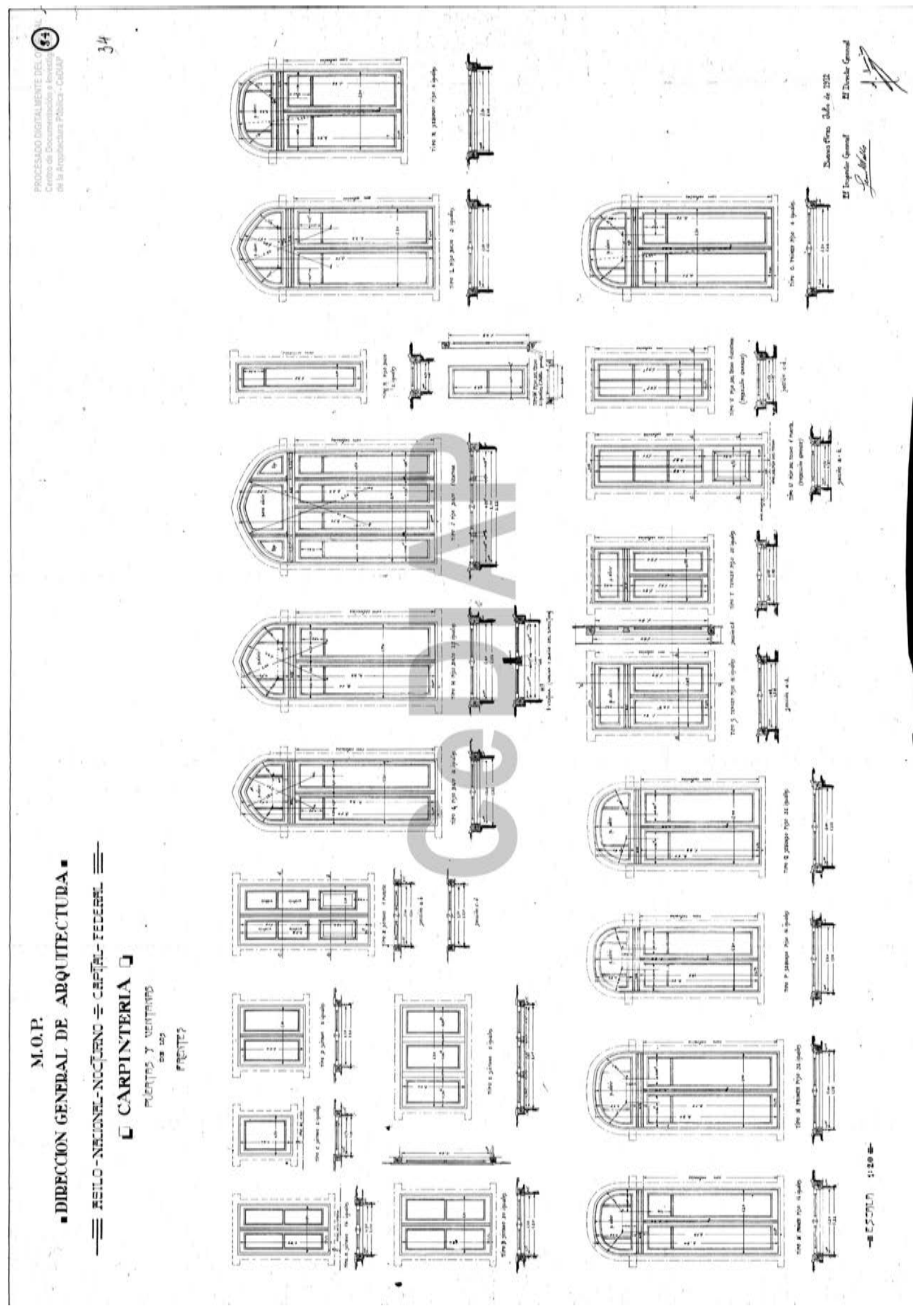

Fig. $N^{\circ}$ 21.- DETALLE CARPINTERÍA DE FRENTES

Conjunto Edilicio Ministerio de Agroindustria de la Nación (ex Asilo Nocturno de la Capital) "Desarrollo de los instrumentos para la Conservación e Intervención del Patrimonio Arquitectónico. Hacia un Plan de Gestión". 

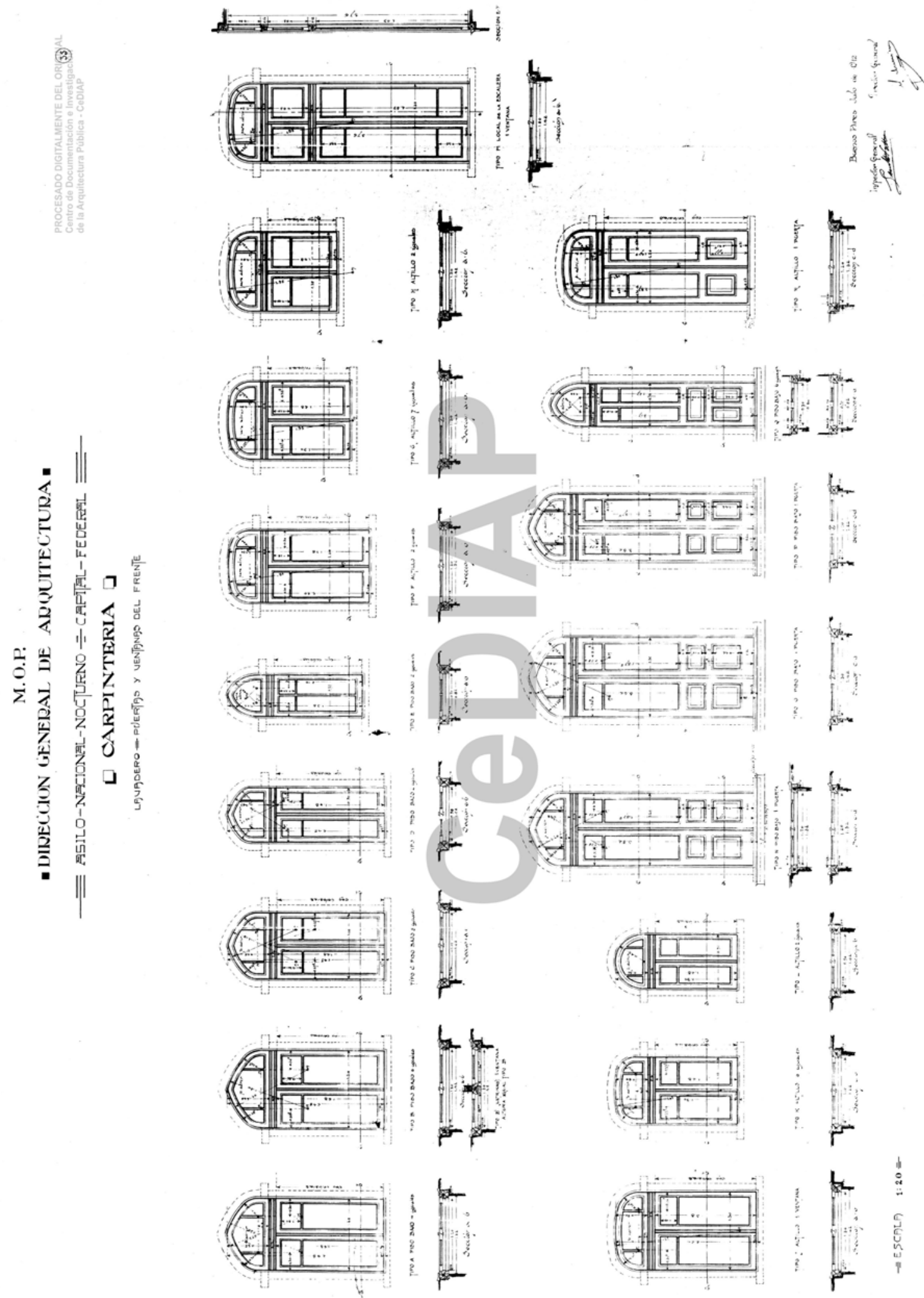

Fig. No 22.- DETALLE CARPINTERÍA DE LAVADERO, PUERTAS Y VENTANAS 
M. (B.?

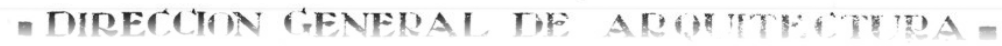

M.O.P.

- DIRECCION GENERAL DE ARQUITECTURA -

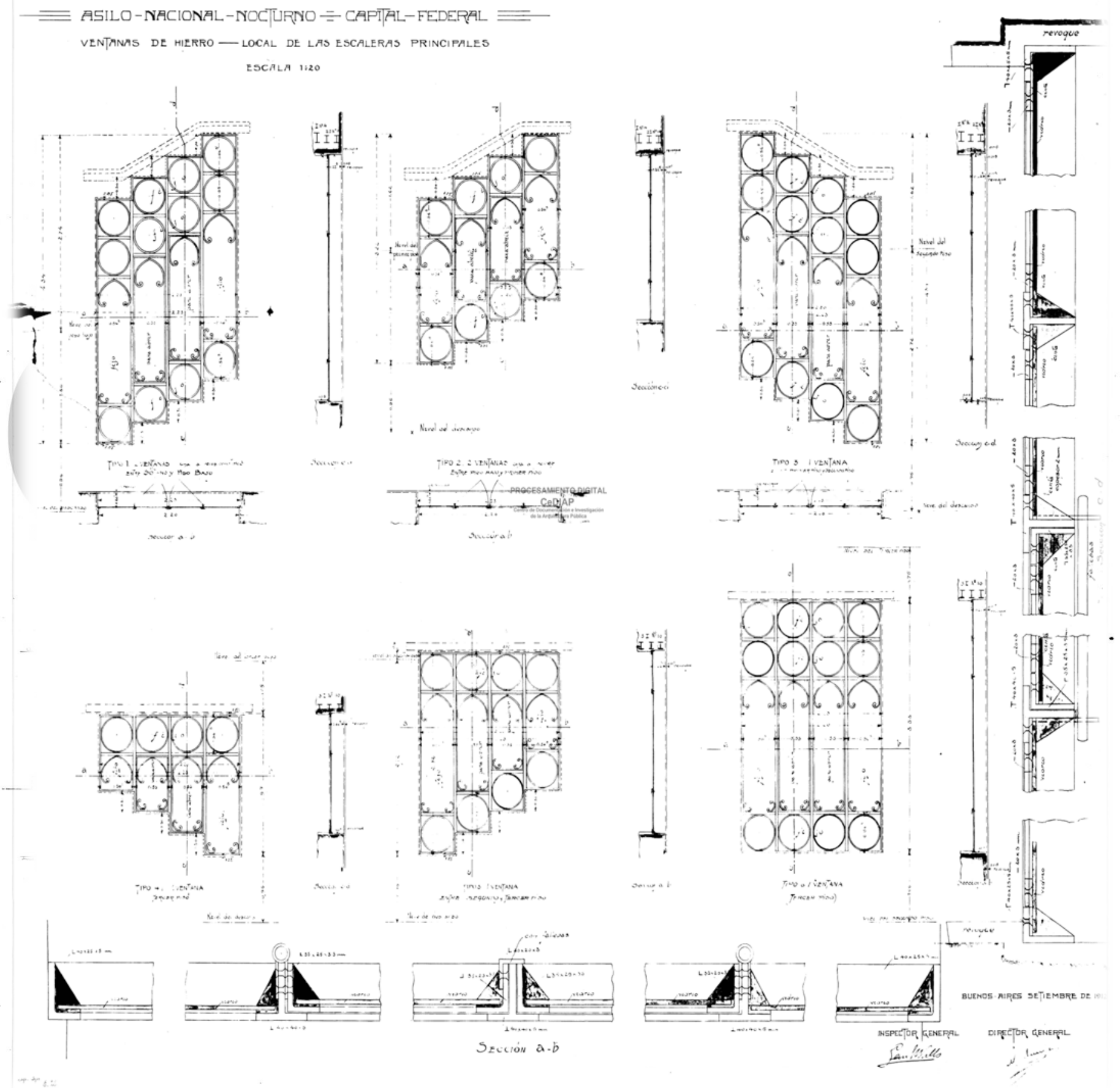

Fig. No 23.- DETALLE VENTANAS DE HIERRO ESCALERA PRINCIPAL

Conjunto Edilicio Ministerio de Agroindustria de la Nación (ex Asilo Nocturno de la Capital) "Desarrollo de los instrumentos para la Conservación e Intervención del Patrimonio Arquitectónico. Hacia un Plan de Gestión". 
FACULTAD DE ARQUITECTURA Y URBANISMO - UNIVERSIDAD NACIONAL DE LA PLATA

MAESTRÍA EN CONSERVACIÓN, RESTAURACIÓN E INTERVENCIÓN DEL PATRIMONIO ARQUITECTÓNICO Y URBANO (CRIP - FAU / UNLP)

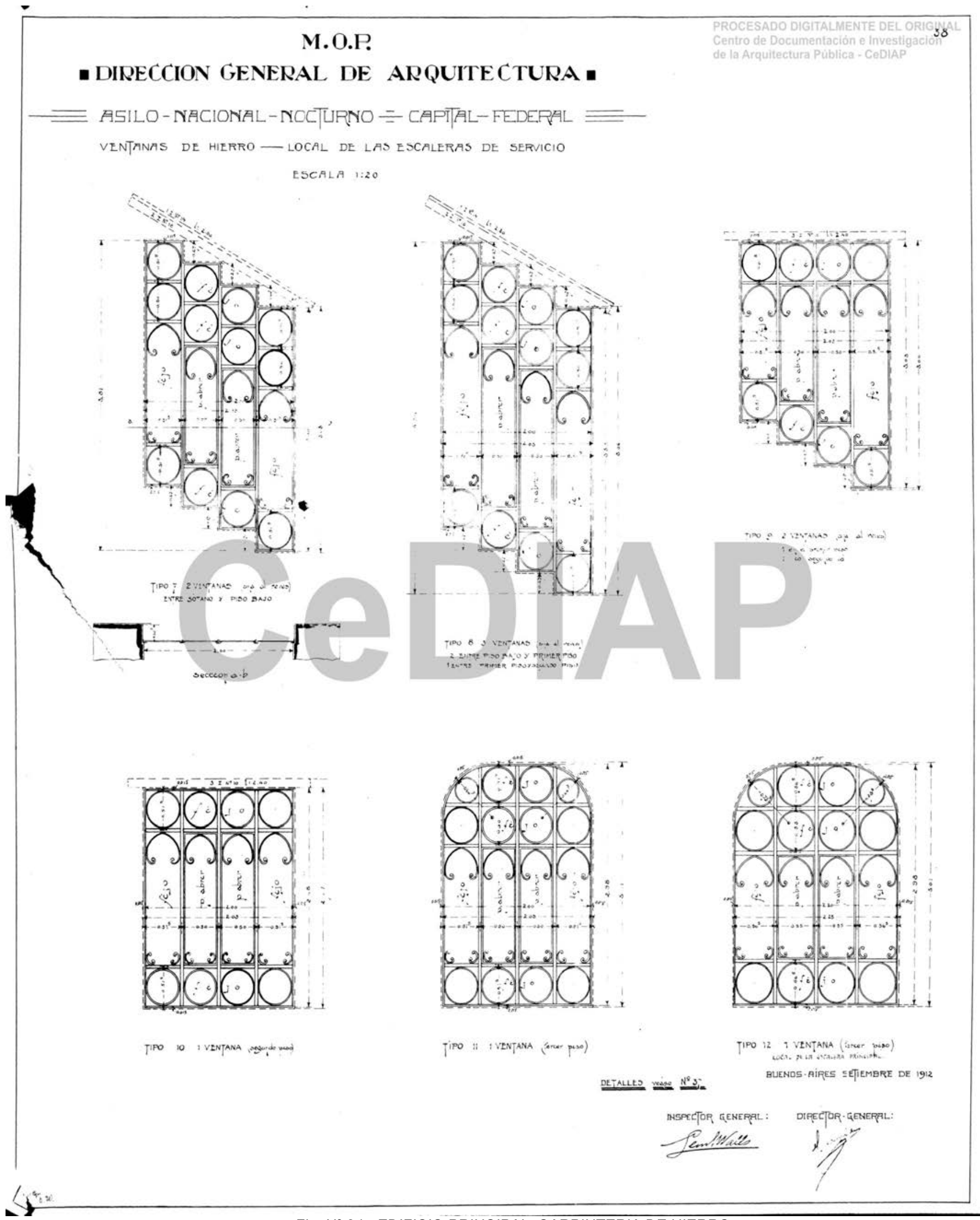

Fig. N ${ }^{\circ}$ 24.- EDIFICIO PRINCIPAL, CARPINTERIA DE HIERRO 


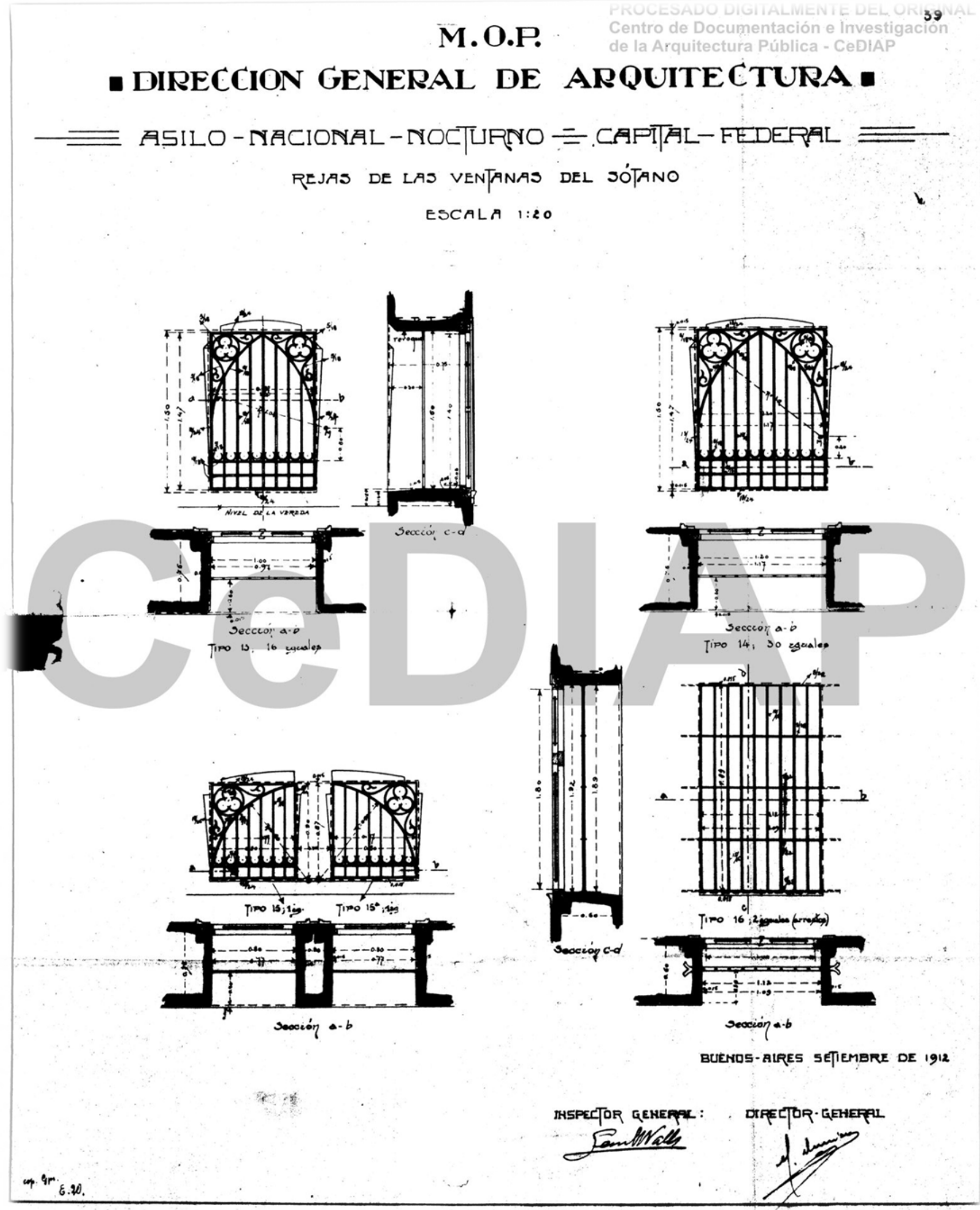

Fig. N²5.- DETALLE EDIFICIO PRINCIPAL, REJA VENTANAS SOTANO 
FACULTAD DE ARQUITECTURA Y URBANISMO - UNIVERSIDAD NACIONAL DE LA PLATA

MAESTRÍA EN CONSERVACIÓN, RESTAURACIÓN E INTERVENCIÓN DEL PATRIMONIO ARQUITECTÓNICO Y URBANO (CRIP - FAU / UNLP)

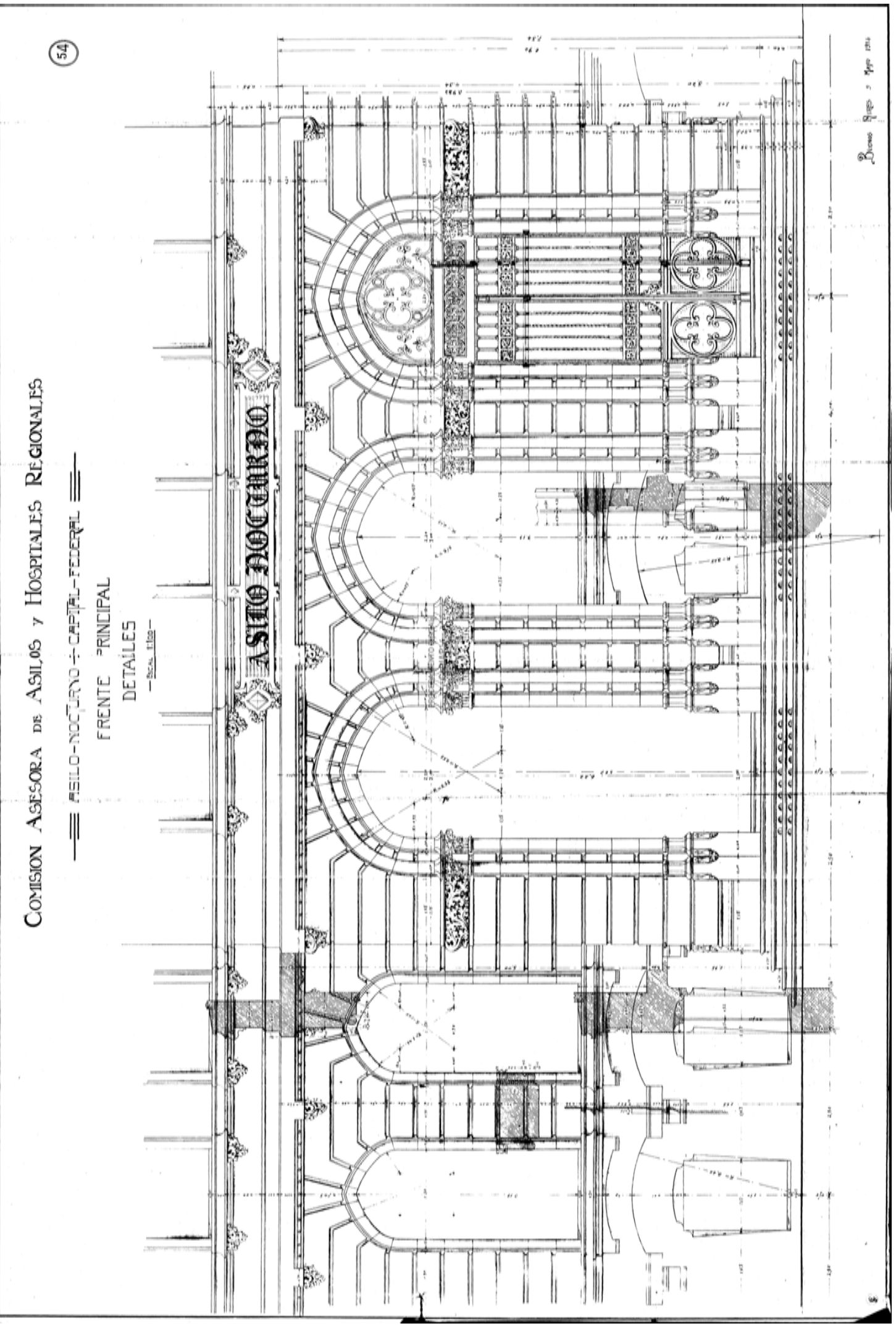

Fig. No 26.- DETALLE FRENTE EDIFICIO PRINCIPAL. 

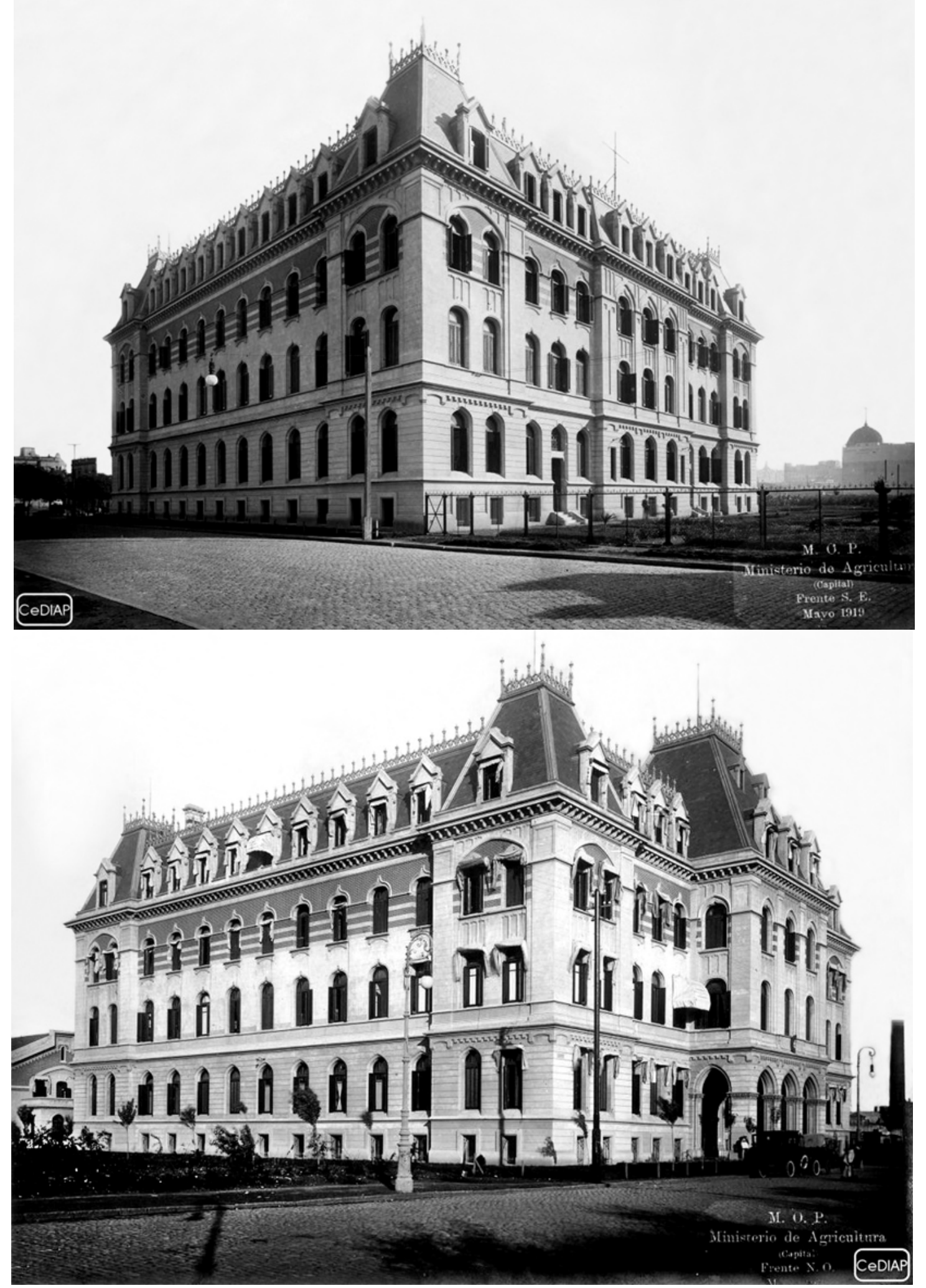

Fig. N 27 y 28.- IMÁGENES EDIFICIO PASEO COLÓN 982

\footnotetext{
$204 \begin{aligned} & \text { Conjunto Edilicio Ministerio de Agroindustria de la Nación (ex Asilo Nocturno de la Capital) } \\ & \text { "Desarrollo de los instrumentos para la Conservación e Intervención del Patrimonio } \\ & \text { Arquitectónico. Hacia un Plan de Gestión". }\end{aligned}$
} 
FACULTAD DE ARQUITECTURA Y URBANISMO - UNIVERSIDAD NACIONAL DE LA PLATA MAESTRÍA EN CONSERVACIÓN, RESTAURACIÓN E INTERVENCIÓN DEL PATRIMONIO ARQUITECTÓNICO Y URBANO (CRIP - FAU / UNLP)
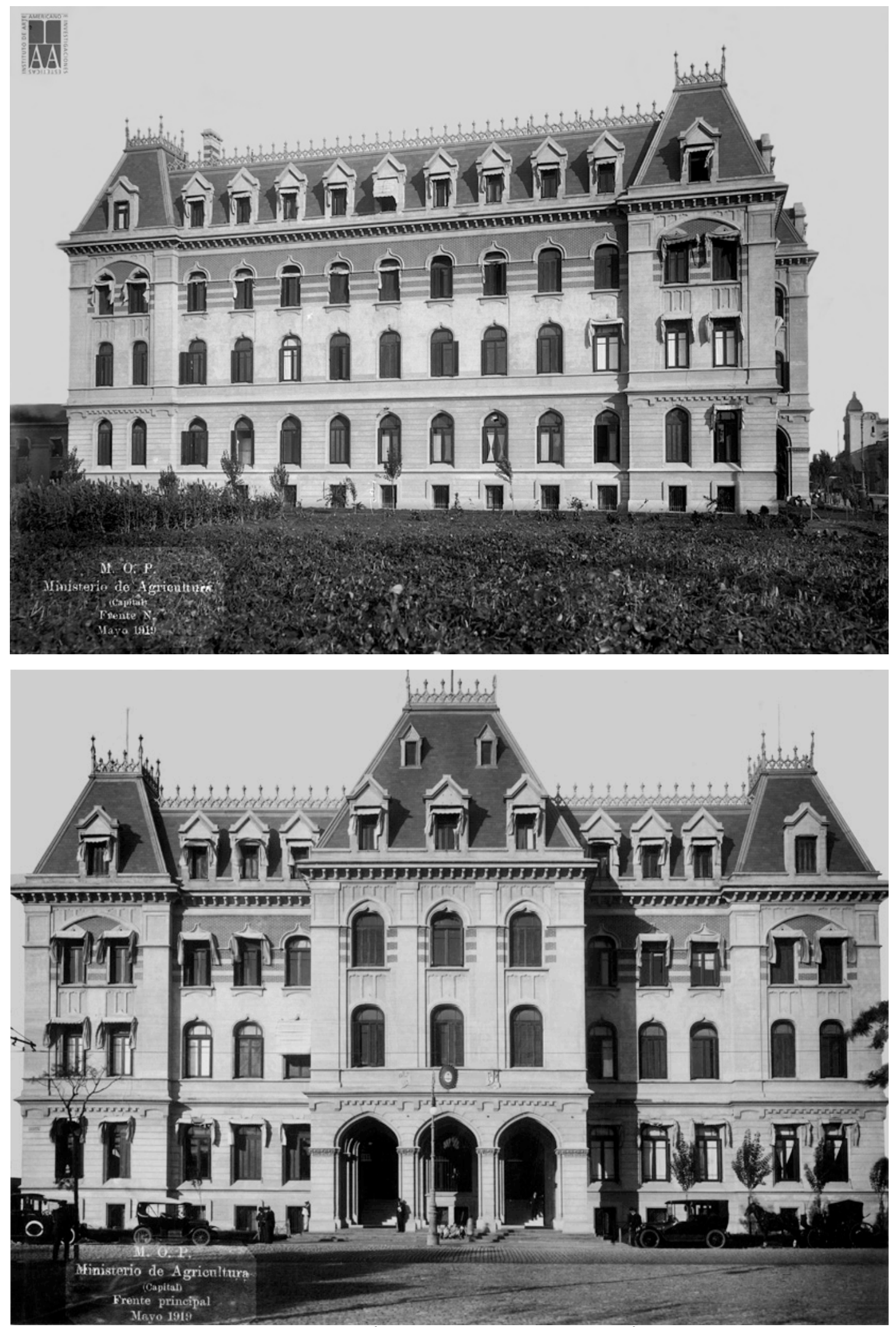

Fig. No 29 y 30.- IMÁGENES EDIFICIO PASEO COLÓN 982 

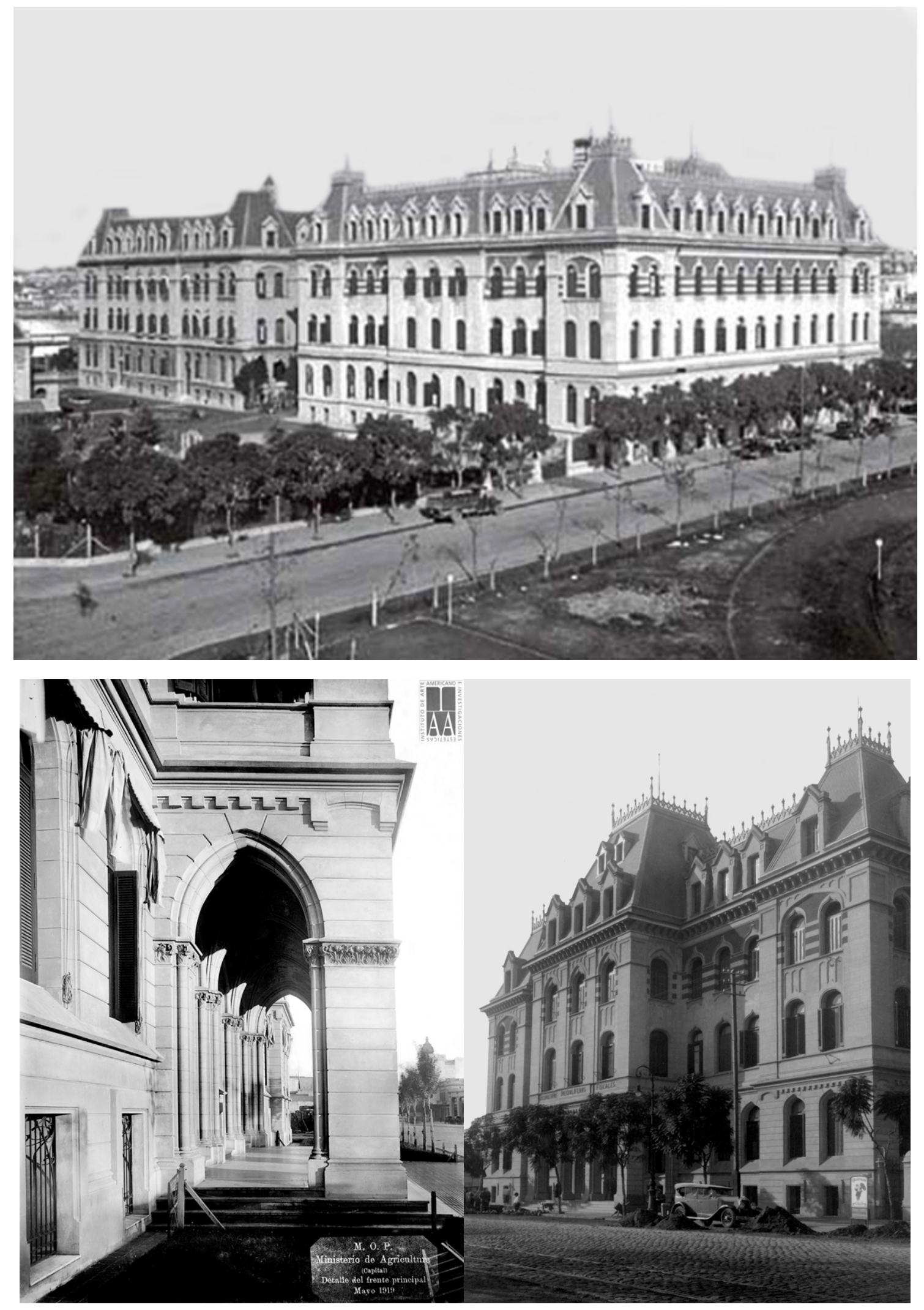

Fig. N 31 a 33.- IMÁGENES CONJUNTO EDILICIO Y DETALLE FRENTE PRINCIPALES

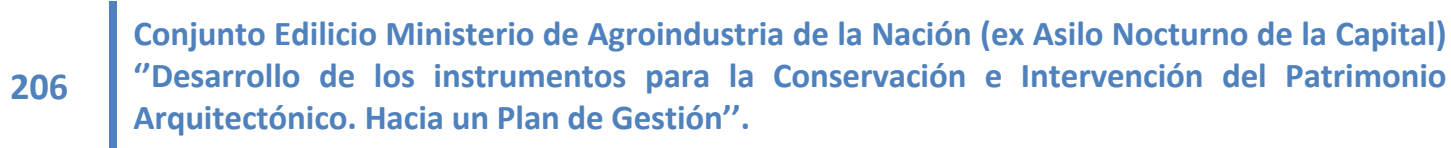


FACULTAD DE ARQUITECTURA Y URBANISMO - UNIVERSIDAD NACIONAL DE LA PLATA MAESTRÍA EN CONSERVACIÓN, RESTAURACIÓN E INTERVENCIÓN DEL PATRIMONIO ARQUITECTÓNICO Y URBANO (CRIP - FAU / UNLP)
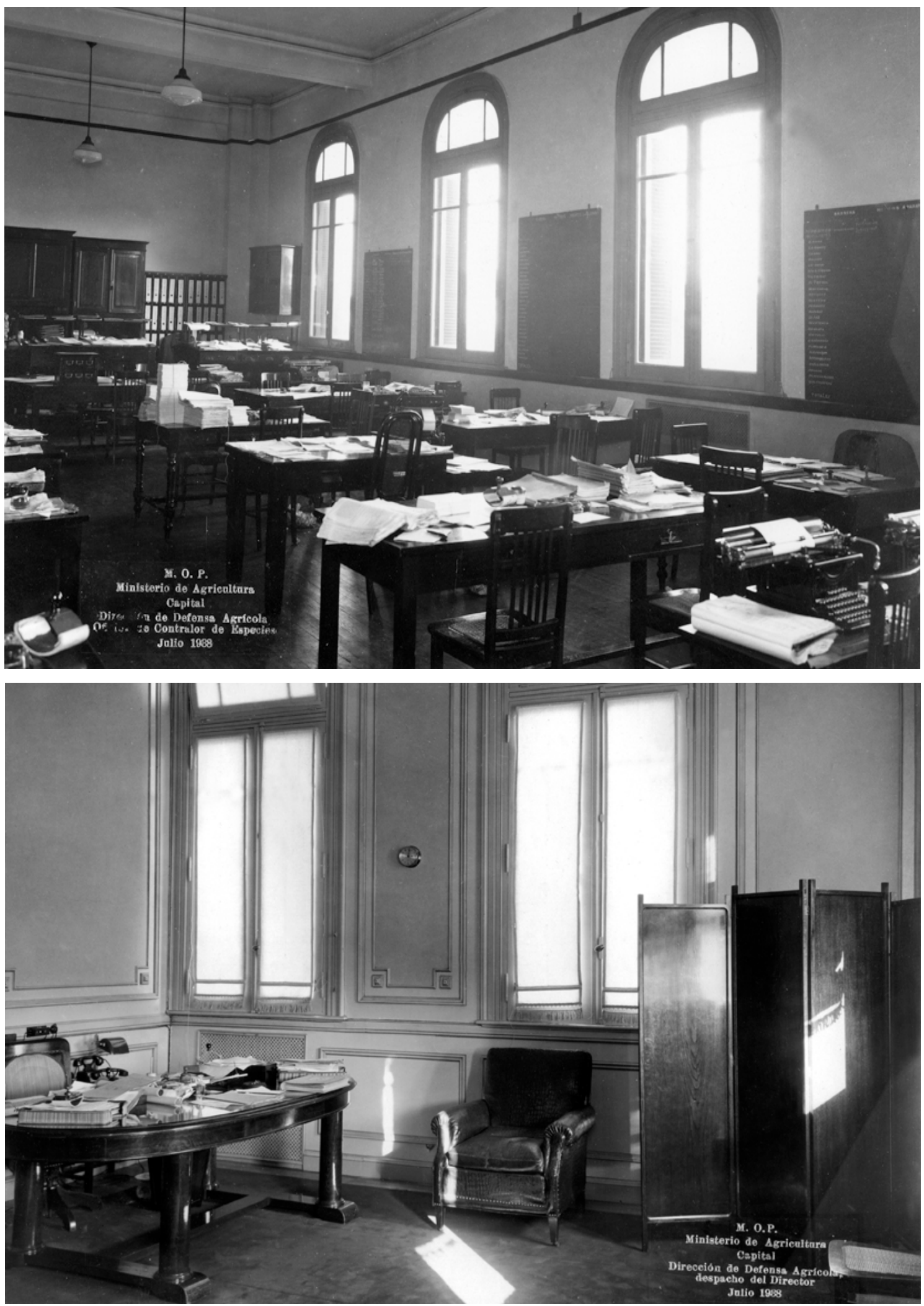

Fig. N No 34 y 35.- IMÁGENES INTERIORES- DIRECCIÓN DE DEFENSA AGRÍCOLA Y DESPACHO DIRECTOR 

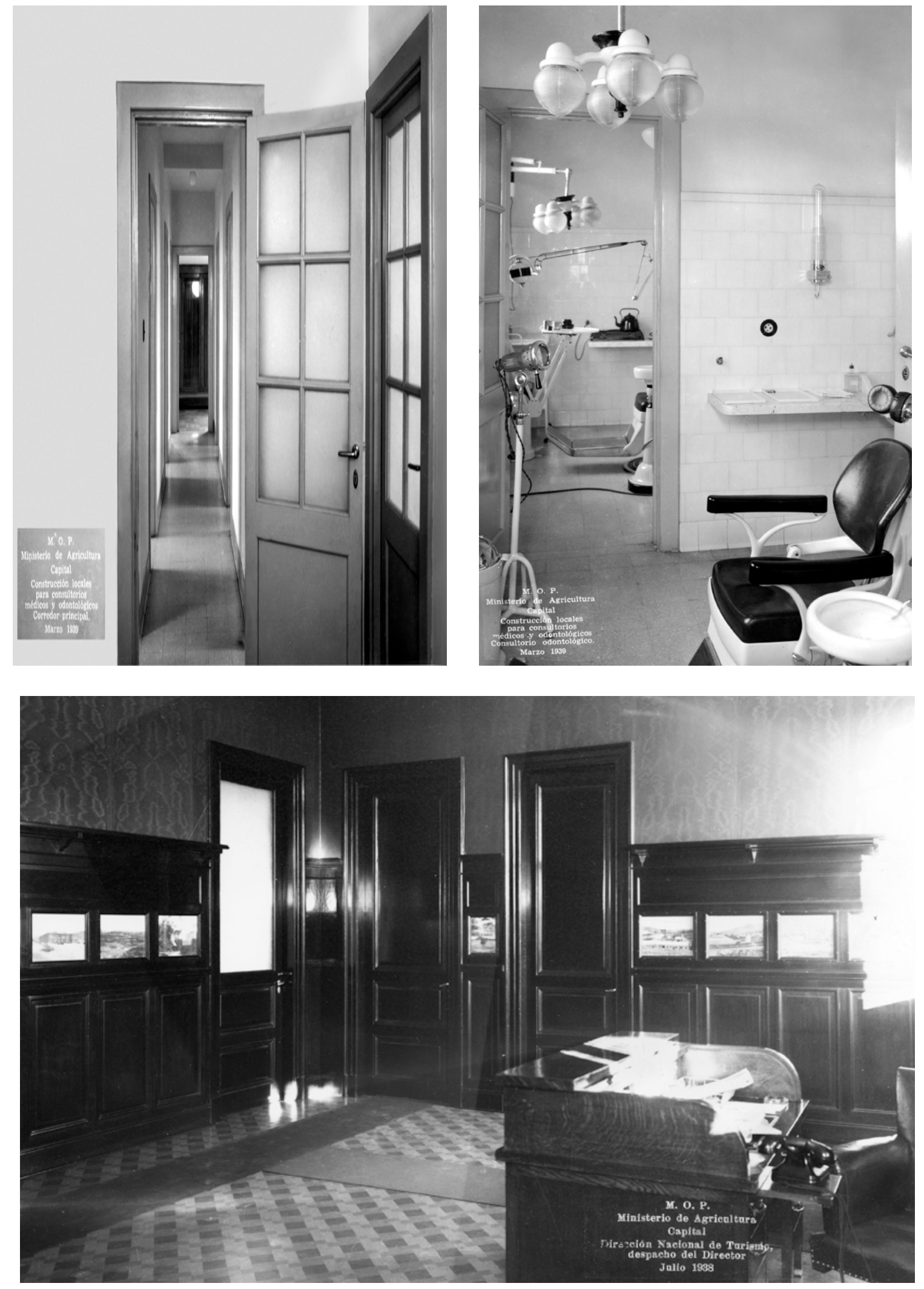

Fig. N 36 a 38.- IMÁGENES INTERIORES- CONSULTORIOS Y DIRECCIÓN NACIONAL DE TURISMO

Conjunto Edilicio Ministerio de Agroindustria de la Nación (ex Asilo Nocturno de la Capital) "Desarrollo de los instrumentos para la Conservación e Intervención del Patrimonio Arquitectónico. Hacia un Plan de Gestión". 